\title{
$\mathrm{N}-$ Heterocyclic Carbene-Catalyzed Synthesis of Ynones via C-H Alkynylation of Aldehydes with Alkynyliodonium Salts
}

\author{
Adam A. Rajkiewicz, Natalia Wojciechowska, Marcin Kalek
}

Submitted date: 07/10/2019 Posted date: 11/10/2019

Licence: CC BY-NC-ND 4.0

Citation information: Rajkiewicz, Adam A.; Wojciechowska, Natalia; Kalek, Marcin (2019): N-Heterocyclic Carbene-Catalyzed Synthesis of Ynones via C-H Alkynylation of Aldehydes with Alkynyliodonium Salts. ChemRxiv. Preprint.

Alkynylation of aldehydes with alkynyl(aryl)iodonium salts catalyzed by an N-heterocyclic carbene (NHC) has been developed. The application of the organocatalyst and the hypervalent iodine group-transfer reagent allowed for metal-free $\mathrm{C}-\mathrm{H}$ functionalization and $\mathrm{C}-\mathrm{C}$ bond formation. The reaction proceeds under exceptionally mild conditions, at $-40^{\circ} \mathrm{C}$ and in the presence of an amine base, providing access to an array of heteroaryl-propargyl ketones containing various substituents in good to excellent yields. The mechanism of the reaction was investigated by means of both experiments and density functional theory calculations. 13C-labelling and computations determined that the key alkynyl transfer step occurs via an unusual direct SN2 substitution of iodine-based leaving group by Breslow intermediate nucleophile at an acetylenic carbon. Moreover, kinetic studies revealed that the turnover-limiting step of the catalytic cycle is the generation of the Breslow intermediate, whereas the subsequent $\mathrm{C}-\mathrm{C}$ bond-formation is a fast process. These results were fully reproduced and rationalized by the computed full free energy profile of the reaction, showing that the largest energy span is located between protonated NHC and the transition state for the carbene attack on the aldehyde substrate.

File list (2)

Kalek_NHC-alkynylation.pdf (1.78 MiB) view on ChemRxiv - download file 


\section{$N$-Heterocyclic Carbene-Catalyzed Synthesis of}

\section{Ynones via C-H Alkynylation of Aldehydes with}

\section{Alkynyliodonium Salts}

Adam A. Rajkiewicz ${ }^{*,}$, Natalia Wojciechowskat, and Marcin Kalek ${ }^{* *}$

${ }^{\dagger}$ Centre of New Technologies, University of Warsaw, Banacha 2C, 02-097 Warsaw, Poland

Faculty of Chemistry, University of Warsaw, Pasteura 1, 02-093 Warsaw, Poland

Keywords: NHC organocatalysis, ynones, hypervalent iodine, alkynylation, mechanistic studies

\section{ABSTRACT}

Alkynylation of aldehydes with alkynyl(aryl)iodonium salts catalyzed by an $N$-heterocyclic carbene (NHC) has been developed. The application of the organocatalyst and the hypervalent iodine group-transfer reagent allowed for metal-free $\mathrm{C}-\mathrm{H}$ functionalization and $\mathrm{C}-\mathrm{C}$ bond formation. The reaction proceeds under exceptionally mild conditions, at $-40{ }^{\circ} \mathrm{C}$ and in the presence of an amine base, providing access to an array of heteroaryl-propargyl ketones containing various substituents in good to excellent yields. The mechanism of the reaction was investigated by means of both experiments and density functional theory calculations. ${ }^{13} \mathrm{C}$-labelling and computations determined that the key alkynyl transfer step occurs via an unusual direct $\mathrm{S}_{\mathrm{N}} 2$ substitution of iodine-based leaving group by Breslow intermediate nucleophile at an acetylenic 
carbon. Moreover, kinetic studies revealed that the turnover-limiting step of the catalytic cycle is the generation of the Breslow intermediate, whereas the subsequent $\mathrm{C}-\mathrm{C}$ bond-formation is a fast process. These results were fully reproduced and rationalized by the computed full free energy profile of the reaction, showing that the largest energy span is located between protonated NHC and the transition state for the carbene attack on the aldehyde substrate. 


\section{INTRODUCTION}

Over the last two decades, the organocatalysis with $\mathrm{N}$-heterocyclic carbenes (NHCs) has established a strong position in synthetic organic chemistry. Its success stems primarily from enabling a smooth access to a group of versatile nucleophilic species, such as Breslow intermediate (acyl anion equivalent), homoenolate, acylazolium enolate, and other, via the umpolung of abundant carbonyl substrates. The coupling of these nucleophiles with a plethora of electrophiles has allowed for the development of numerous highly useful synthetic methods. ${ }^{1}$ In the recent years, the applicability of NHC catalysis is being further expanded by employing novel unconventional electrophilic partners, which provide a direct entry to important structural motiffs. ${ }^{2}$ One class of such electrophilic reagents that has recently opened new opportunities in NHC organocatalysis are hypervalent iodine compounds. Due to the ability of iodine atom to undergo a very energetically favorable reduction from + III to + I oxidation state, accompanied by a simultaneous bond formation involving its ligands (resembling a reductive elimination at a metal center), the hypervalent iodine species are superior atom- and group-transfer reagents. ${ }^{3}$ At the same time, they lack the toxicity and high price of transition metal catalysts, making them a good alternative from the environmental and economical viewpoints. ${ }^{4}$ The group transfer reagents based on hypervalent iodine have been used in a number of organocatalyzed reactions, ${ }^{5}$ but there is so far only a handful examples of NHC-promoted processes utilizing these unique electrophilic coupling partners. ${ }^{6}$

Ynones, or propargyl ketones, are a prominent class of organic compounds. First, the ynone motif is present in several biologically active molecules. ${ }^{7}$ Even more importantly, the combined reactivities of the triple bond and the carbonyl group give rise to numerous reactions, wherein ynones serve as precursors for the preparation of a diverse array of molecular scaffolds. ${ }^{8,9}$ The high 
synthetic utility of ynones is proven by their application as key intermediates in multiple total syntheses. ${ }^{10}$

Ynones have traditionally been synthesized by one of three methods: (1) the reaction of metal acytylides with acyl chlorides or other carboxylic derivatives; (2) the oxidation of propargylic position in alkynes or of propargylic alcohols; and (3) a carbonylative cross-coupling. ${ }^{8 f, 11}$ An interesting alternative to these standard approaches that has recently gained attention is the direct alkynylation of the $\mathrm{C}-\mathrm{H}$ bond in aldehydes (Scheme 1). ${ }^{12}$ Such strategy possesses the advantage of providing propargyl ketones in a single synthetic step from abundant and stable starting materials. The first example employing this concept was reported by Zhou and co-workers in 2015, who described a rhodium- and iridium-catalyzed alkynyl transfer from ethynylbenziodoxolone (EBX) to aromatic aldehydes (Scheme 1a).${ }^{13}$ The reaction proceeds via the incipient directing group-assisted activation of the formyl $\mathrm{C}-\mathrm{H}$ to form a metal carbonyl complex. The second existing approach to effect the alkynylation of aldehydes relies on the homolytic cleavage of the $\mathrm{C}-\mathrm{H}$ bond. The groups of Wei, $\mathrm{Yu}$, and Li described independently the synthesis of ynones in the presence of tert-butyl hydroperoxide as a radical initiator (Scheme 1b). ${ }^{14}$ Despite the robustness and simplicity of these methods, their considerable disadvantage is the high reaction temperature required, imposing constraints on the scope. To alleviate the above drawback, Glorius and coworkers employed photoredox catalysis to generate radicals from aldehydes (Scheme 1b). ${ }^{15}$ By the application of iridium complex, the alkynylation of a variety of aldehydes with EBX could be carried out at room temperature.

Scheme 1. Synthesis of Ynones via Direct C-H Alkynylation of Aldehydes. 


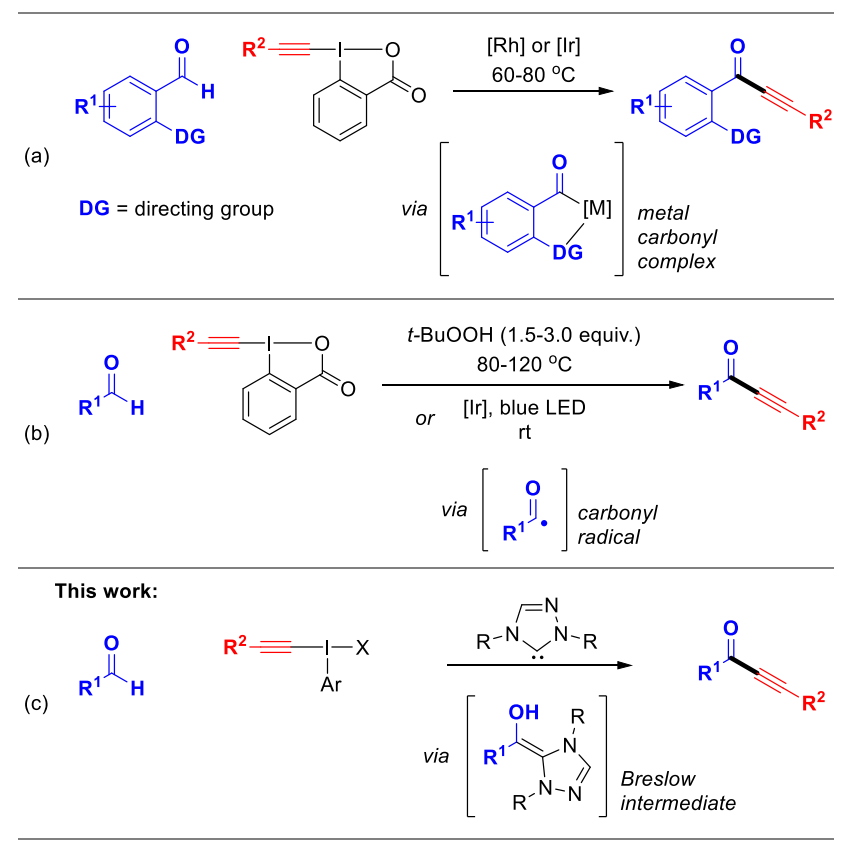

Building on the seminal work by Gaunt on the NHC-catalyzed arylation of aldehydes, ${ }^{6 \mathrm{a}}$ as well as on our own studies on the vinylation of aldehydes, ${ }^{6 \mathrm{~b}}$ we envisioned that the formation of a Breslow intermediate by the action of an NHC catalyst on aldehyde substrate may constitute an alternative mean to activate the formyl $\mathrm{C}-\mathrm{H}$ bond allowing for the subsequent alkynyl group transfer. Herein, we present our work on the development of a novel NHC-catalyzed direct C-H alkynylation of aldehydes outlined in Scheme 1c. Importantly, the reaction makes use of alkynyl(aryl)iodonium salts as the alkynyl group donor, in contrast to all of the previously reported methods that employ EBX reagents (Schemes 1a and 1b). While alkynyl(aryl)iodonium salts have been widely applied for the direct alkynylation of heteroatom nucleophiles and enolates of 1,3dicarbonyl compounds, ${ }^{16,17}$ their use for transferring alkynyl moiety to less trivial carbon nucleophiles have usually required transition metal catalysis. ${ }^{18}$ On the contrary, the application of NHC organocatalyst gives rise to an efficient metal-free $\mathrm{C}-\mathrm{C}$ bond formation involving a noteworthy acyl anion equivalent. In addition to the synthetic studies, we perform a thorough 
mechanistic investigations of this new transformation by the combination of experimental and computational approaches. In particular, we identify the turnover-limiting step of the catalytic cycle and elucidate that the transfer of alkynyl moiety from the iodonium salt to the Breslow intermediate follows an unusual pathway of a direct $\mathrm{S}_{\mathrm{N}} 2$ substitution at an acetylenic carbon atom.

\section{RESULTS AND DISSCUSSION}

Synthetic studies. First, we investigated the effect of a number of reaction parameters on a model coupling between 2-quinoxalinecarbaldehyde $\mathbf{1 a}$ and phenylethynyl(aryl)iodonium salts containing different auxiliary aryl groups and counter-ions (Table 1). The established optimal conditions consist of $\mathrm{N}$-pentafluorophenyl-triazolium carbene precursor NHC-1, tetramethylethylenediamine (TMEDA) as the base, and toluene at $-40{ }^{\circ} \mathrm{C}$, affording ynone $3 \mathbf{a}$ in $86 \%$ yield (entry 1 ). The structure of the iodonium salt was found to be crucial for the selective and efficient alkynyl group transfer. ${ }^{19}$ Mesityl was identified as the superior auxiliary aryl group, securing the formation of product in high yield (entry 1). Less sterically hindered, including singly ortho-substituted, aryls lead to a loss of the selectivity of the transfer, and to the formation of a bisaryl ketone side-product (entries 2-4). The presence of two ortho substituents in $o$-xylyl suppresses the side aryl-transfer, but the desired ynone is furnished is a lower yield than for the mesityl-containing salt $\mathbf{2 a}$ (entry 5 vs. 1). A significant effect of the counter-ion was also observed. The best result was obtained with a tosylate salt (entry 1), whereas iodonium trifluoromethanosulfonate and trifluoroacetate display only a moderate reactivity (entries 6-7), and a tetrafluoroborate salt is quite ineffective (entry 8). Finally, we tested EBX reagent $\mathbf{4}$, but it provides only traces of product under these conditions (entry 9). Importantly, the optimal 
alkynyl(mesityl)iodonium tolsylates of type 2a are stable and easy to handle, and they can be very conveniently prepared by the method reported by Stang. ${ }^{20}$

Table 1. Effect of Reaction Parameters ${ }^{a}$

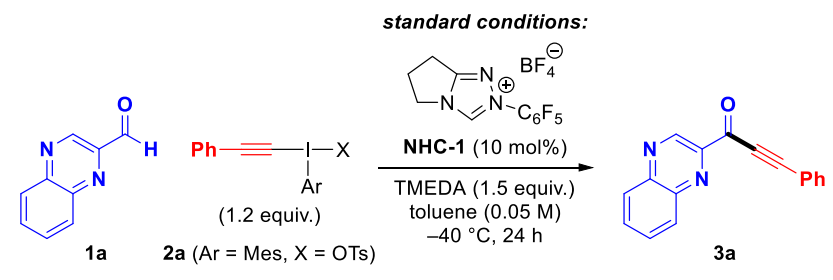

\begin{tabular}{|c|c|c|}
\hline entry & deviation from the standard conditions & yield $(\%)$ \\
\hline 1 & - & 86 \\
\hline 2 & $\mathrm{Ar}=\mathrm{Ph}(\mathbf{2} \mathbf{b})$, instead of $\mathrm{Ar}=\mathrm{Mes}$ & $38(16)^{c}$ \\
\hline 3 & $\mathrm{Ar}=o-$ anisyl $(\mathbf{2 c})$, instead of $\mathrm{Ar}=\mathrm{Mes}$ & $17(11)^{c}$ \\
\hline 4 & $\mathrm{Ar}=o$-tolyl (2d), instead of $\mathrm{Ar}=$ Mes & $73(20)^{c}$ \\
\hline 5 & $\mathrm{Ar}=o-$ xylyl (2e), instead $\mathrm{Ar}=$ Mes & 67 \\
\hline 6 & $X=\operatorname{OTf}(\mathbf{2 f})$, instead of $X=$ OTs & 64 \\
\hline 7 & $\mathrm{X}=\mathrm{CF}_{3} \mathrm{COO}(\mathbf{2 g})$, instead of $\mathrm{X}=\mathrm{OTs}$ & 66 \\
\hline 8 & $\mathrm{X}=\mathrm{BF}_{4}(\mathbf{2 h})$, instead of $\mathrm{X}=\mathrm{OTs}$ & 24 \\
\hline 9 & Ph-EBX (4), instead of $\mathbf{2 a}$ & 4 \\
\hline 10 & NHC-2, instead of NHC-1 & 50 \\
\hline 11 & NHC-3, instead of NHC-1 & 58 \\
\hline 12 & NHC-4, instead of NHC-1 & 11 \\
\hline 13 & NHC-5, instead of NHC-1 & $<1$ \\
\hline 14 & NHC-6, instead of NHC-1 & $<1$ \\
\hline 15 & NHC-7, instead of NHC-1 & 19 \\
\hline 16 & $5 \mathrm{~mol} \%$ of $\mathbf{N H C}-1$ & 64 \\
\hline 17 & no NHC-1 & $<1$ \\
\hline
\end{tabular}


$18 \quad 0^{\circ} \mathrm{C}$, instead of $-40{ }^{\circ} \mathrm{C}$

19 r.t., instead of $-40{ }^{\circ} \mathrm{C}$

20 DMAP, instead of TMEDA

21 DABCO, instead of TMEDA

$22 \mathrm{~K}_{3} \mathrm{PO}_{4}$, instead of TMEDA

23 DCE, instead of toluene

$24 \mathrm{CH}_{2} \mathrm{Cl}_{2}$, instead of toluene

$25 \mathrm{MeCN}$, instead of toluene

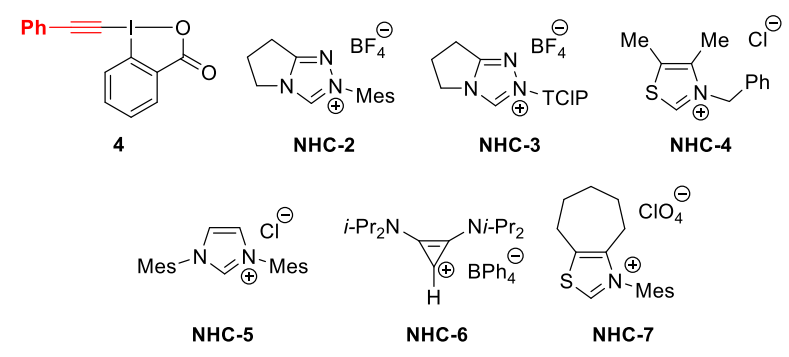

${ }^{a}$ All data are the average of two experiments. ${ }^{b}$ Determined through analysis by ${ }^{1} \mathrm{H}$ NMR spectroscopy. ${ }^{c}$ The formation of bisaryl ketone side-product was observed, its yield is given in parenthesis. ${ }^{d}$ At $-35{ }^{\circ} \mathrm{C}$. Mes $=2,4,6$-trimethylphen-1-yl; OTs $=p$-tolenesulfonate; OTf $=$ trifluoromethanesulfonate; TCIP = 2,4,6-trichlorophen-1-yl; DCE =1,2-dichloroethane.

As far as the other reaction parameters are concerned, we found that the different types of NHCs commonly used in organocatalysis (entries 10-15) are inferior to the commercially available NHC-1, bearing an electron deficient pentafluorophenyl group. Lowering of the catalyst loading from 10 to $5 \mathrm{~mol} \%$ decreases the yield to a moderate level (entry 16) and no product formation is observed in the absence of catalyst (entry 17). Elevated temperatures have an adverse effect on the reaction (entries 18-19). Application of other organic amine bases results in moderate to good yields (entries 20-21), while inorganic bases are ineffective in this transformation (e.g., entry 22). Interestingly, more polar solvents that completely solubilize the reactants are not as efficient as toluene, which affords a heterogenous reaction mixture. 
Having established the optimal conditions for the NHC-catalyzed alkynylation of aldehydes, we proceeded to evaluate the scope and limitations of this reaction. An array of heteroaromatic aldehydes could be efficiently alkynylated (Scheme 2). In particular, arylpropargyl ketones containing heterocyclic six-membered rings with nitrogen, such as quinoxaline (3a), quinoline (3b), and pyridine (3g-3l), as well as five-membered rings, e.g., pyrazole (3c- $\mathbf{3 d})$ and thiazole (3e-3f), were synthesized in good to excellent yields. The ability to incorporate these moieties is highly advantageous, as they are prevalent in therapeutically important molecules. ${ }^{21} \mathrm{~A}$ number of functional groups is tolerated under the reaction conditions, including aryl bromide (3i), double (3k), and triple (31) bonds, providing useful handles for further functionalization and built-up of the molecular complexity. The method is also compatible with fluorinated substituents $(\mathbf{3 h}$ and 3j), which adds to its value for the synthesis of pharmaceutically relevant compounds. ${ }^{22}$ On the downside, benzaldehydes are poor substrates and only the one containing a strongly electronwithdrawing nitro group afforded the desired product in an admissible yield (3m). Also, aliphatic aldehydes were found to be completely incompetent starting materials.

Scheme 2. Scope with Regard to the Aldehyde 


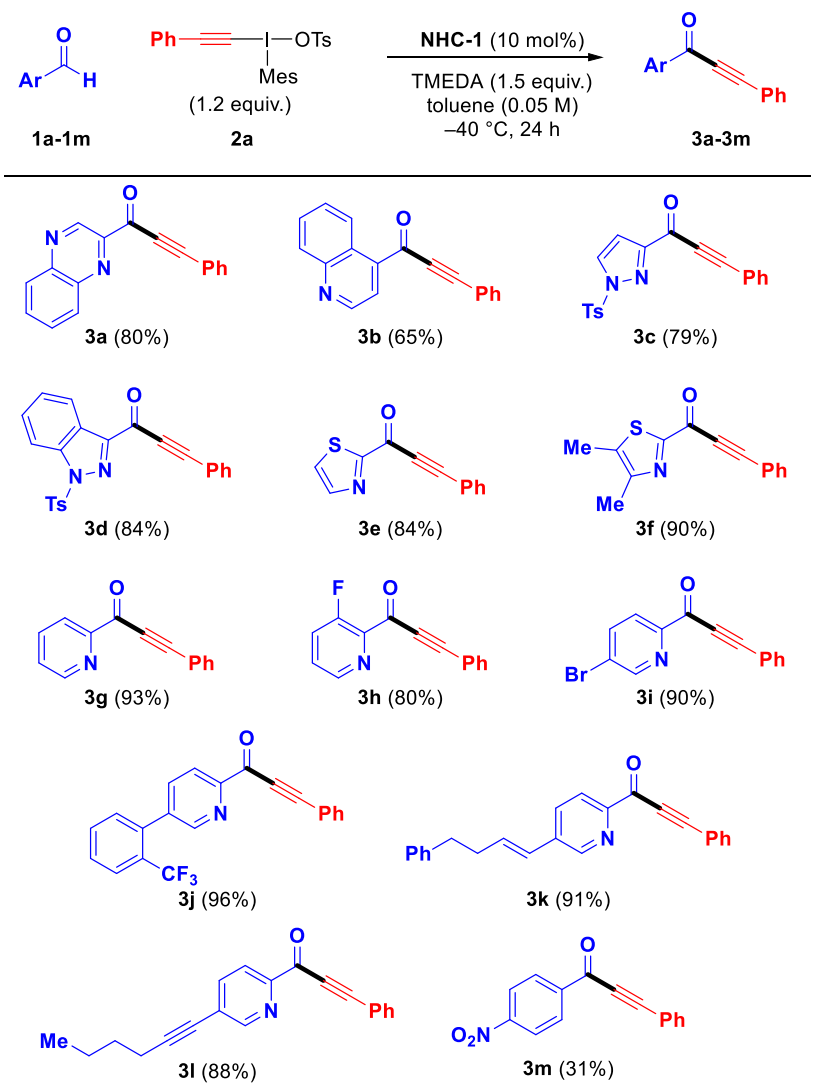

Next, we examined the scope with regard to the alkynyliodonium salt. The method could be applied to transfer a range of arylethynyl groups, containing a multitude of substituents (Scheme 3). All the alkyl-substituted (3n, 3o), aryl-substituted (3p), as well as extended (3q) aryl systems can be incorporated into the product. The reaction proceeds equally well for arylethynyl moieties bearing both electron-withdrawing and electron-donating groups. Thus, regardless of the substituent position, ynones containing halogens (3r and $\mathbf{3 t}$ ), trifluromethyl (3s), cyano (3u), ketone (3v), ester (3w), and ether $(\mathbf{3 x}-\mathbf{3 y})$ functionalities were synthesized in good to excellent yields. Notably, we also prepared propargyl ketones with a phtalamide-masked amine (3z) and a sulfonamide (3aa), demonstrating a broad functional group tolerance of the developed methodology. Unfortunately, when iodonium salts containing alkylethynyl groups were tested, the desired product was not formed under these conditions. 
Scheme 3. Scope with Regard to the Alkynyliodonium Salt

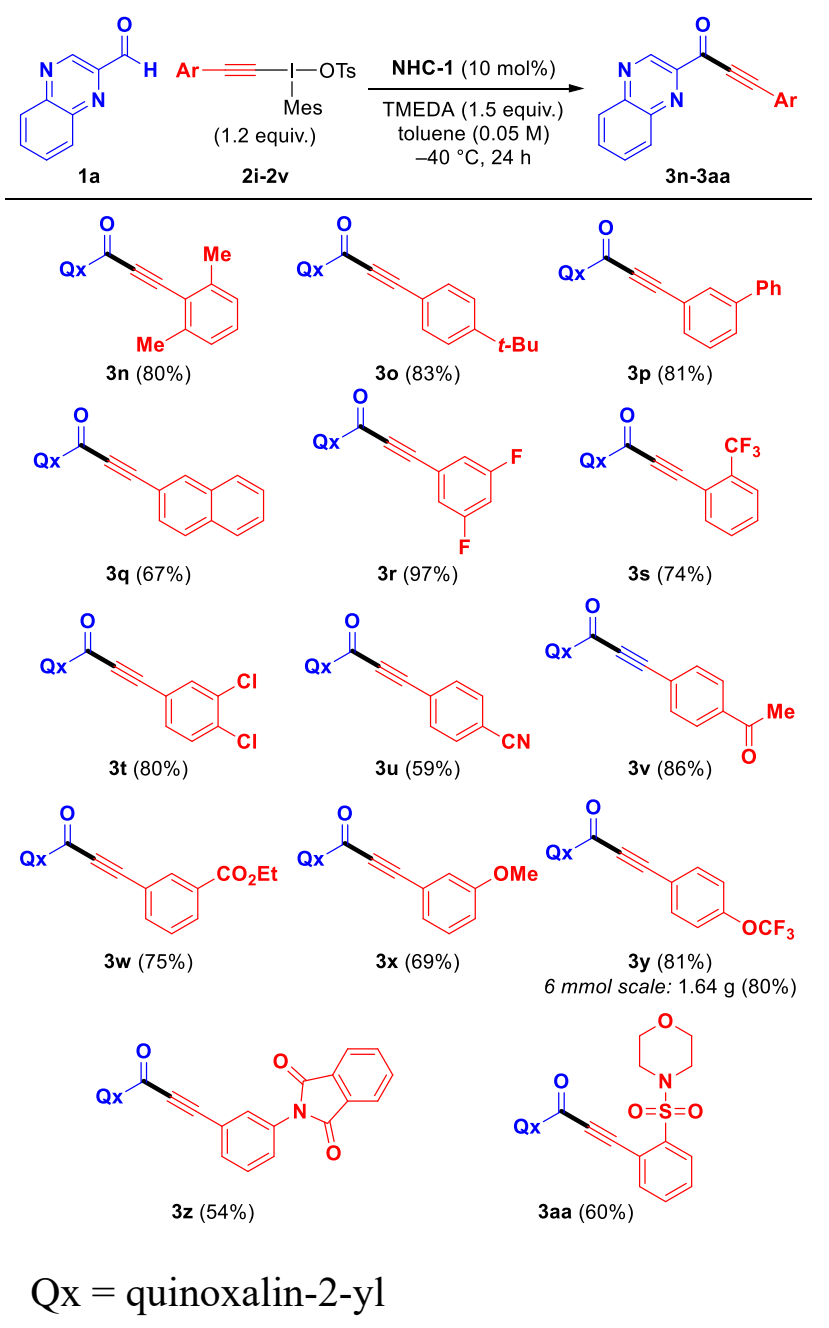

Finally, to validate the synthetic utility of the developed procedure, we have applied it to synthesize compound $\mathbf{3 y}$ on a gram scale, which was obtained without any appreciable loss in the yield $(80 \%, 1.64 \mathrm{~g}$ of product).

Experimental mechanistic studies. The hypervalent iodine compounds bearing an alkynyl group contain three distinct electrophilic centers: the iodine atom, the $\alpha$-carbon of the triple bond, and 
the $\beta$-carbon of the triple bond. Therefore, the reactions involving such reagents may in principle follow three general mechanistic pathways, outlined in Scheme 4 for the particular case of the NHC-catalyzed alkynylation of aldehydes with alkynyliodonium salts. In the first scenario the nucleophile, Breslow intermediate, is incorporated into the coordination sphere of iodine (Scheme 4a). After the expulsion of $\mathrm{NHC}$ catalyst, the key $\mathrm{C}-\mathrm{C}$ bond-formation takes place via a reductive ligand coupling, affording the ynone product. This type of mechanism is common for related aryl transfer reactions with diaryliodonium salts, as revealed by several computational investigations. ${ }^{23}$ The second possibility is a direct $\mathrm{S}_{\mathrm{N}} 2$ substitution at the $\alpha$-acetylenic carbon, i.e., the displacement of iodine acting as a leaving group by the attacking nucleophile (Scheme $4 \mathrm{~b}$ ). Such a mechanistic route has so far been shown to operate only in a single instance of alkynyl transfer from hypervalent iodine species, namely for the alkynylation of thiols with EBX reagents. ${ }^{24}$ In the final alternative, the nucleophile attacks at the $\beta$-carbon of the triple bond in a Michel-type conjugate addition (Scheme 4c). The resulting iodonium ylide, after a prior elimination of NHC, undergoes a fragmentation producing a vinylidene carbene intermediate. Subsequently, the vinylidene carbene rearranges to the final product by a 1,2-shift of the aryl substituent. This last mechanism is accepted to be implicated in the majority of alkynylations with hypervalent iodine reagents and there exists strong experimental evidence supporting such a pathway. In particular, first, in multiple cases the iodonium ylide could be trapped by protonation, yielding isolable vinyliodonium derivatives. ${ }^{25}$ Secondly, in the absence of any substituents prone to migration, the emergence of products originating from the insertion of the vinylidene carbene into $\mathrm{C}-\mathrm{H}$ bonds has been observed. ${ }^{17 k, 26}$ Finally, the acetylenic carbons have been shown to swap their positions during the reactions with ${ }^{13} \mathrm{C}$-labeled alkynyliodonium starting materials, in line with the 1,2-shift step. ${ }^{24,26 a, 27}$ 
Scheme 4. Outline of Possible General Mechanisms

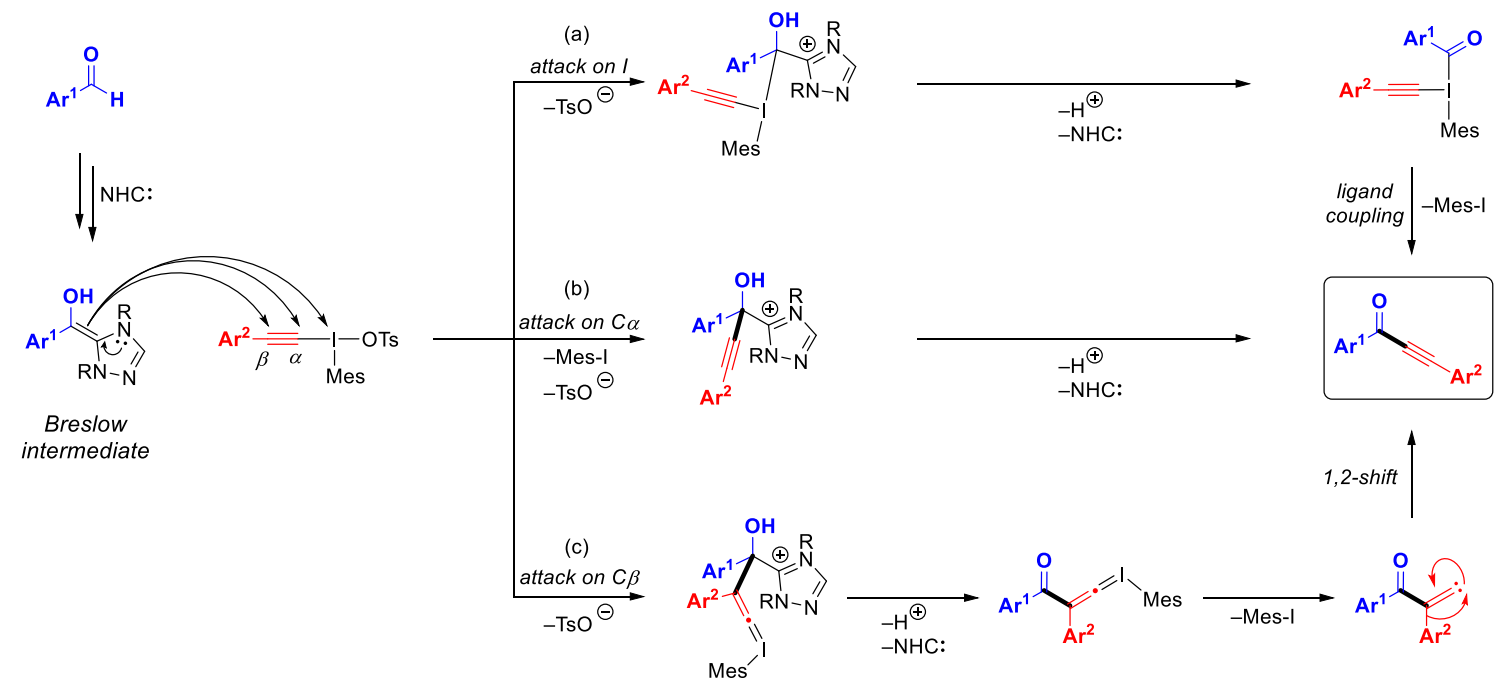

The fact that alkylethynyliodonium salts are not effective in the NHC-catalyzed reaction (vide supra) suggested that it may follow the most common pathway staring with the nucleophilic attack on the $\beta$-carbon (Scheme 4c), since the alkyl substituents are not likely to undergo the $1,2-$ migartion. On the other hand, we did not observe any products originating from the insertion of the vinylidene carbene into the $\mathrm{C}-\mathrm{H}$ bonds of the alkyl chains, either. Therefore, in order to obtain a more direct proof distinguishing between the different possible mechanisms, we carried out the alkynylation of aldehyde 1a using iodonium salt $2 \mathbf{w}$ that was labeled with ${ }^{13} \mathrm{C}$ at the $\alpha$-carbon (Scheme 5). The resulting product 3ab was generated in an unchanged yield compared to its unlabeled counterpart ( $c f$. 3a in Scheme 2) and it contained the ${ }^{13} \mathrm{C}$ label exclusively incorporated at the acetylenic carbon adjacent to the carbonyl group. Such an outcome allows to unambiguously eliminate the attack of Breslow intermediate on the $\beta$-carbon of the alkynyliodonium salt (Scheme 4c) as the valid pathway of the investigated reaction. 
Scheme 5. NHC-Catalyzed Alkynaltion of Aldehyde 1a with Alkynyliodonium Salt 2w Labelled with ${ }^{13} \mathrm{C}$ at the $\alpha$-Carbon.

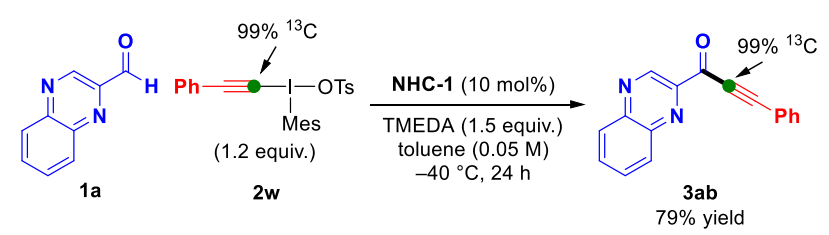

Stimulated by the result of above experiment, demonstrating that the developed reaction does not follow the most prevalent mechanism for alkynylations with hypervalent iodine compounds, we decided to perform more thorough investigations of this interesting process. To obtain insight into its course, we carried out kinetics investigations. First, the progress of the reaction under the optimized conditions was monitored over time (Figure 1a). The analysis of the decay of the starting material shows that the reaction displays overall second order in the concentrations of the substrates, as the linear dependence of reciprocal substrate concentration vs. time was observed (Figure 1b). ${ }^{28}$

Figure 1. (A) Time-course of the NHC-Catalyzed Alkynylation of Aldehyde 1a with Alkynyliodonium salt 2a in $d 8$-Toluene at $-40{ }^{\circ} \mathrm{C} .{ }^{a, b}$ (B) Corresponding Plot of Reciprocal Substrate Concentration vs. Time. 

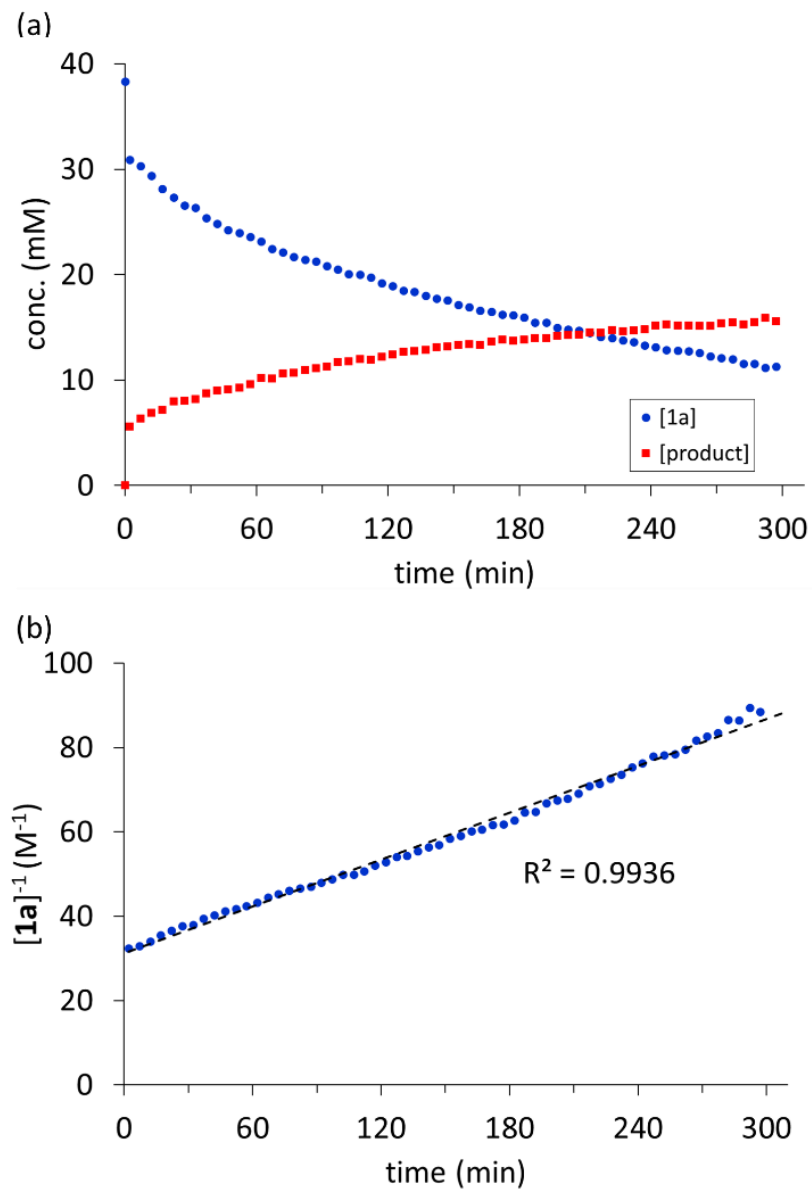

${ }^{a}$ The concentrations were determined by ${ }^{1} \mathrm{H}$ NMR spectroscopy relative to internal standard. ${ }^{b}$ The initial leap in the concentrations is due to a temporary heating of the sample during the addition of the initiating reagent (TMEDA).

In order to ascribe the orders to the concentrations of specific reagents, we conducted an initial rate study. Our first attempts to follow the initial rates under the optimized conditions were unsuccessful, as erratic and irreproducible time curves were being obtained. We were able to trace this problem to the heterogeneity of the reaction mixture, and, thus, upon switching the solvent from $d_{8}$-toluene to $\mathrm{CDCl}_{3}$, which solubilizes all the reactants at the reaction temperature of $-40{ }^{\circ} \mathrm{C}$, better quality data could be acquired. However, due to the technical difficulties of measuring the reaction kinetics at so low temperature, the alignment of the data points is still not perfect (see the 
Supporting Information for details). Anyhow, despite considerable error bars, we are confident that we were able to grasp the kinetic characteristics of the transformation.

Figure 2. Initial Rate Measurements for the NHC-Catalyzed Alkynylation of Aldehyde 1a with Alkynyliodonium Salt 2a in $\mathrm{CDCl}_{3}$ at $-40{ }^{\circ} \mathrm{C}$, with Varied Concentration of (a) 1a, (b) 2a, (c) TMEDA, and (d) NHC-1. The Insets Show the Corresponding LN-LN Plots. ${ }^{a}$
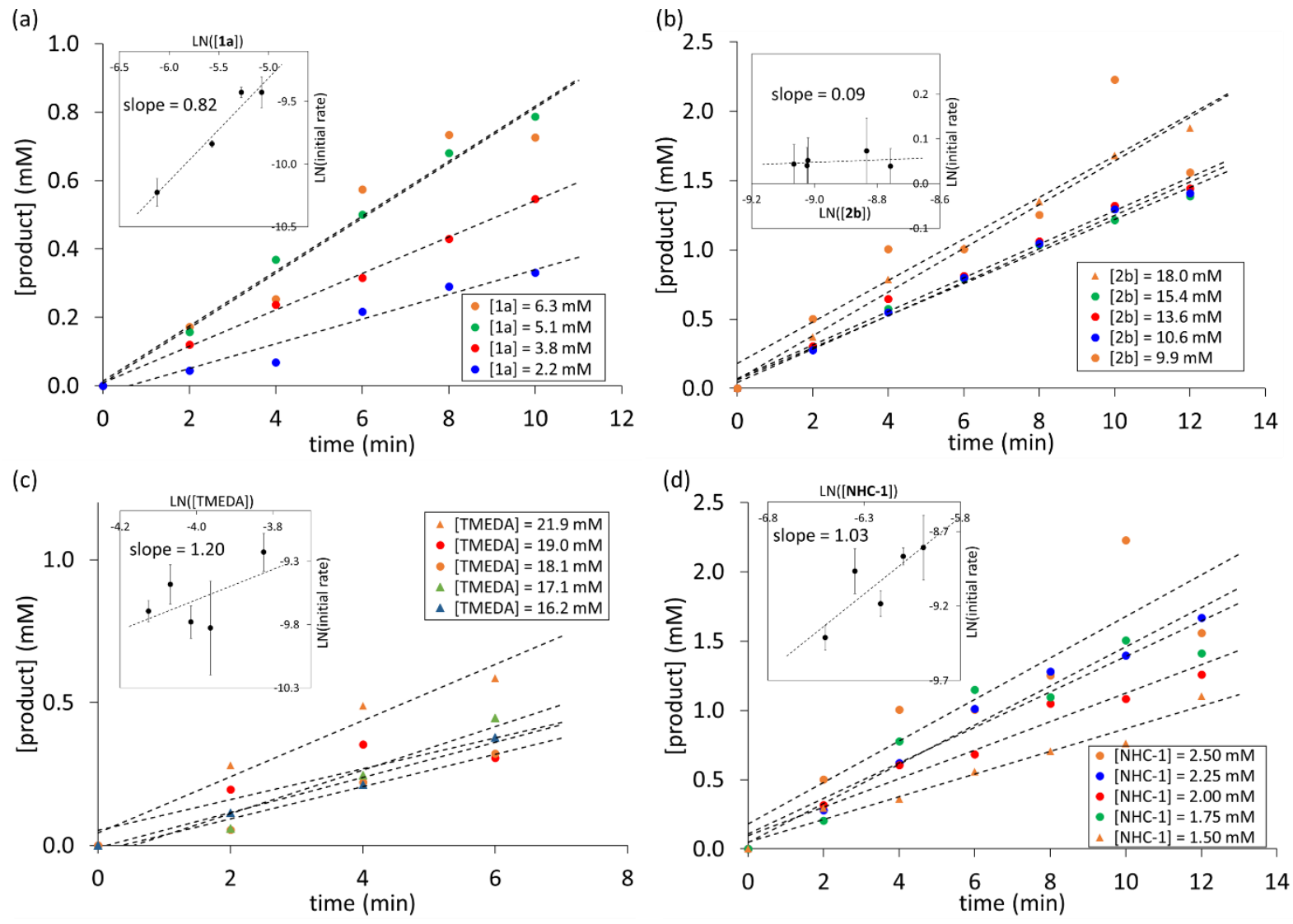

${ }^{a}$ Product concentration was determined by ${ }^{1} \mathrm{H}$ NMR spectroscopy relative to internal standard.

Figure 2 presents the initial rate plots measured with varied concentrations of the respective reagents and the catalyst precursor. The analysis of this data results in an experimental rate law, wherein the reaction is first order in the concentrations of 1a, TMEDA, and NHC-1, whereas 
zeroth order in the concentration of $\mathbf{2 a}$ (eq 1). This is in agreement with the overall second order in the substrates (i.e., 1a and TMEDA), determined from the reaction monitored over a longer period (Figure 1; the concentration of NHC-1 is constant with conversion, hence its influence on the rate does not appear in that experiment).

rate $=k[\mathbf{1} \mathbf{a}][$ TMEDA $][$ NHC-1 $]$

The presence of the aldehyde and the NHC precatalyst concentrations in rate law (1) directly implies that the formation of Breslow intermediate is the turnover-limiting step of the catalytic cycle. In turn, since the concertation of the alkynyliodonium salt does not impact the rate, the subsequent key $\mathrm{C}-\mathrm{C}$ bond formation must be a fast step, demonstrating a very high mutual affinity between the alkynyliodonium salt and the Breslow intermediate. Taking this into account, the appearance of the concertation of TMEDA in the rate law indicates its involvement also during the generation of the Breslow intermediate, in addition to the deprotonation needed to expel NHC toward the end of the mechanism (Scheme 4).

Computational studies. To gain insight into the details of the catalytic cycle and complement the mechanistic picture obtained in the previous section, we performed a computational density functional theory (DFT) investigation. The alkynylation of 2-pyridinecarboxaldehyde (1g) with (mesityl)(phenylethynyl)iodonium tosylate (2a) using precatalyst NHC-1 was employed as a model reaction in the calculations. The computations were carried out at B3LYP-D3BJ/Def2QZVP//B3LYP-D3BJ/Def2-SVPD level of theory with the modelling of toluene solvation using SMD method for both the geometry optimizations and the final energy calculations (see the 
Supporting Information for the full computational details). ${ }^{29}$ Figure 3 shows the free energy profile for the mechanism established by the calculations.

The initial formation of the Breslow intermediate was found to occur according to the standard mechanism implicated for the NHC-catalyzed processes. ${ }^{1 \mathrm{c}}$ Thus, the reaction begins by a facile deprotonation of catalyst precursor NHC-1 with TMEDA via transition state TS1. The resulting free carbene $\mathbf{A}$ is higher in energy by $2.4 \mathrm{kcal} / \mathrm{mol}$ compared to its protonated form. In the following step, the NHC attacks aldehyde 1g, generating alkoxide species $\mathbf{B}$. The overall barrier for this transformation is calculated to be $16.7 \mathrm{kcal} / \mathrm{mol}$ relative to NHC-1. In the next step, B undergoes a barrierless protonation at oxygen by the salt of TMEDA, yielding the corresponding alcohol C. Finally, Breslow intermediate $\mathbf{D}$ is furnished upon the deprotonation of $\mathbf{C}$ at the carbon atom by TMEDA via a low-barrier TS3. Overall, the formation of the Breslow intermediate is exergonic by $2.1 \mathrm{kcal} / \mathrm{mol}$ relative to the catalyst precursor. The highest energy span along the way, amounting to $16.7 \mathrm{kcal} / \mathrm{mol}$ is located between NHC-1 and TS2. Importantly, within this part of the energy diagram all three species, whose concentrations are present in the experimental ratelaw (1), are involved, that is: the catalyst precursor, the aldehyde substrate, and TMEDA. The subsequent stepwise proton-shuttling $(\mathbf{B} \rightarrow \mathbf{D})$ is facile and does not contribute to the reaction rate.

Figure 3. Free Energy Profile for the Alkynylation of Aldehyde 1g with Alkynyliodonium Salt 2a Using Precatalyst NHC-1 in Toluene, Calculated at B3LYP-D3BJ/Def2-QZVP(SMD)//B3LYPD3BJ/Def2-SVPD(SMD) Level of Theory. 


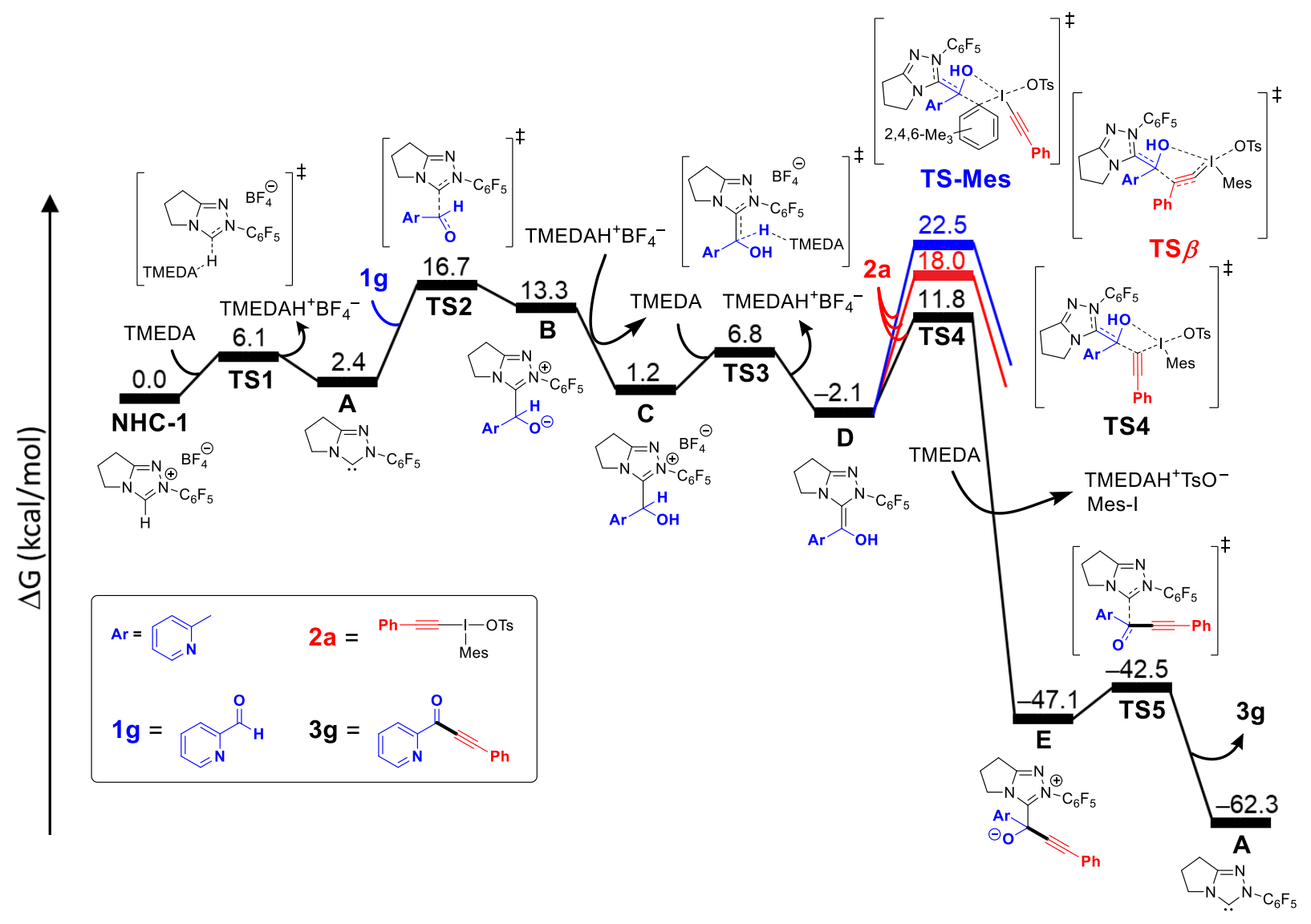

Next, we examined the possible options for the reaction of Breslow intermediate $\mathbf{D}$ with alkynyliodonium salt 2a. It was quickly established that the direct coordination of $\mathbf{D}$ to the iodine center is not feasible, as it does not result in a stable structure that constitutes a minimum on the energy surface. Therefore, the mechanism involving the inner-sphere reductive ligand coupling (Scheme 4a) can be discarded. On the other hand, we were capable of finding the plausible transition states, TS4 and TS $\beta$, for the other two alternative pathways, i.e., the $\mathrm{S}_{\mathrm{N}} 2$ substitution at the $\alpha$-carbon (Scheme 4b) and the Michel-type addition to the $\beta$-carbon (Scheme 4c), respectively. The former one is calculated to be clearly energetically favorable over the latter (by $6.2 \mathrm{kcal} / \mathrm{mol}$ ), thus, it constitutes the actual pathway of the $\mathrm{C}-\mathrm{C}$ bond-formation. The transfer of the alkynyl group via TS4 is found to be a very exergonic, thus, irreversible process (by $45.0 \mathrm{kcal} / \mathrm{mol}$ ). This 
is due to the accompanying reduction of iodine from $+\mathrm{III}$ to $+\mathrm{I}$ oxidation state and the loss of hypervalency. For completeness, we calculated the transition state for the transfer of the mesityl group in 2a (TS-Mes), instead of the alkynyl group. Such course of the reaction would require crossing a very high barrier of $24.6 \mathrm{kcal} / \mathrm{mol}$, explaining the excellent performance of the mesityl substituent as the auxiliary non-transferable aryl group in the alkynyl(aryl)iodonium salts.

Figure 4. Optimized Structures of (a) Alkynyliodonium Salt 2a, (b) TS4, (c) TS $\beta$, and (d) TSMes (Distances Are Given in $\AA$ ).

(a)

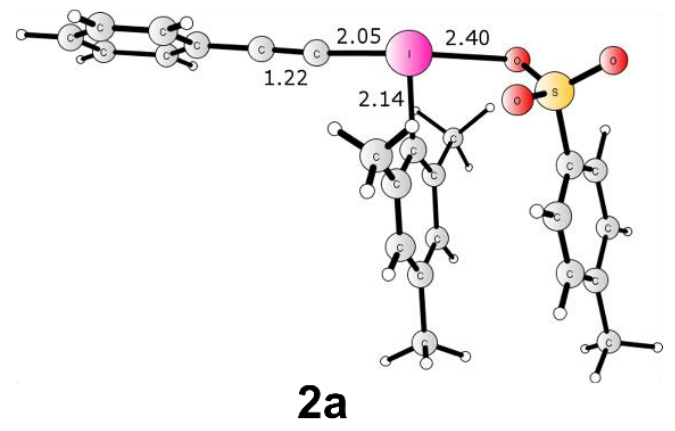

(c)

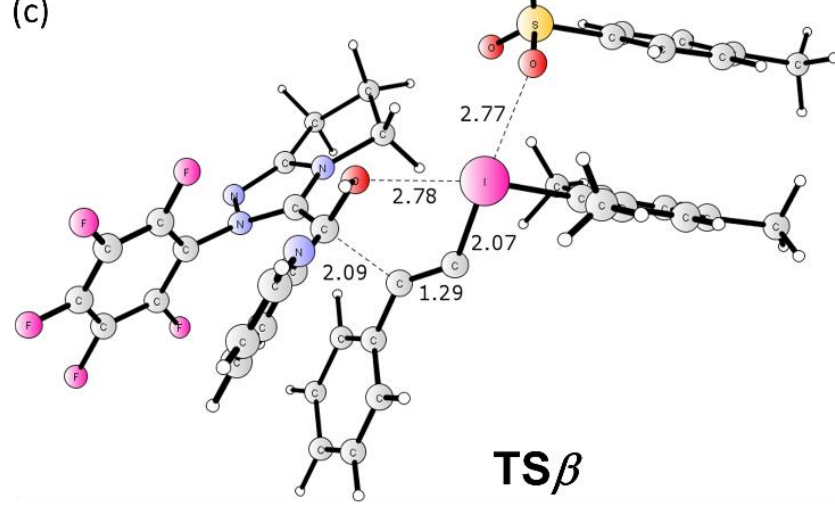

(b)

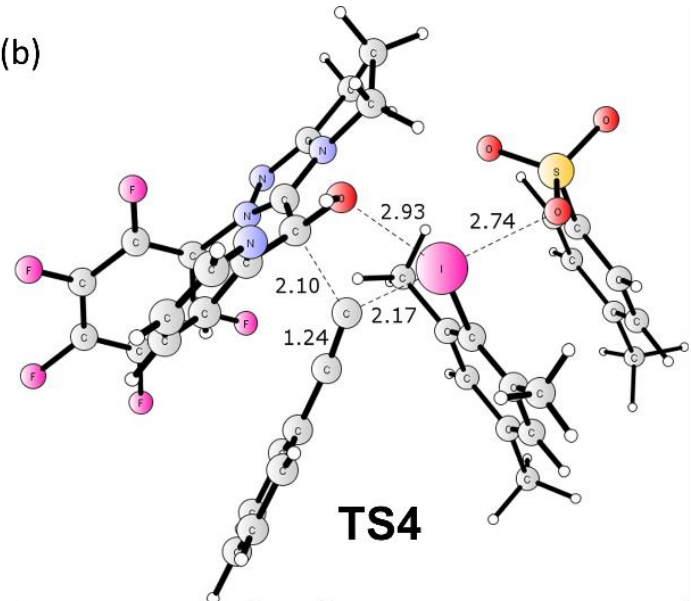

(d)

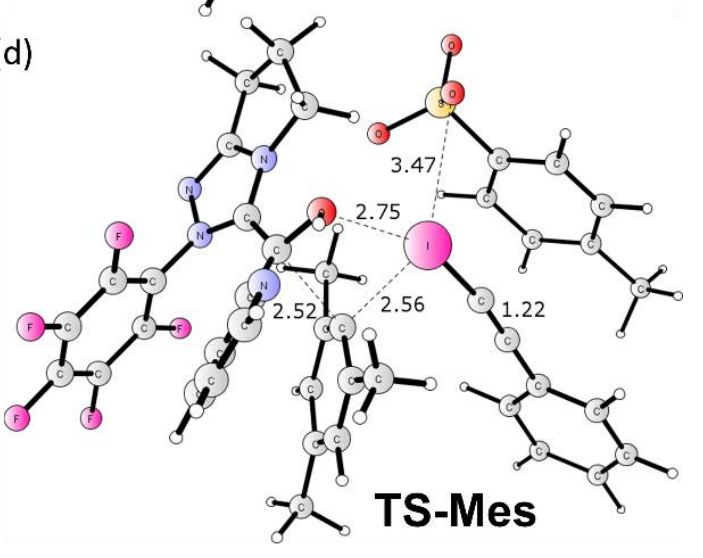

The optimized structures of transition states TS4, TS $\beta$, and TS-Mes, as well as of alkynyliodonium salt $\mathbf{2 a}$, are depicted in Figure 4. In all three transition states the ligand 
participating in the new $\mathrm{C}-\mathrm{C}$ bond formation occupies the hypervalent position. Hence, in the case of TS4 and TS $\beta$ (Figure $4 \mathrm{~b}$ and $4 \mathrm{c}$, respectively), the arrangement of ligands around the iodine center is the same as in the parent salt (Figure 4a), while in TS-Mes the phenylethynyl and mesityl groups are swapped (Figure 4d). Such opposite orientation of the ligands is probably the most significant contributor to the high barrier associated with TS-Mes, as the calculated energy of the isomer of 2a having the mesityl group in the hypervalent position and the alkynyl group in the equatorial position is higher by as much as $10.0 \mathrm{kcal} / \mathrm{mol}$ compared to the energy of $\mathbf{2 a}$. As far as the energy difference between TS4 and TS $\beta$ is concerned, it most likely originates from distorting the conjugation between the forming double $\mathrm{C}-\mathrm{C}$ bond and the phenyl substituent, which due to steric reasons must rotate nearly perpendicularly, in the latter transition state. On the other hand, in TS4, the phenyl ring can align itself in way allowing for a complete $\pi$-conjugation over the triple bond to both the breaking $\mathrm{C}-\mathrm{I}$ bond and the newly forming $\mathrm{C}-\mathrm{C}$ bond, providing stabilization. Importantly, in all the TSs, the hydroxyl group of Breslow intermediate is interacting with the iodine center. This is somewhat similar to the case of alkynylation of thiols with EBX, wherein the thiolate nucleophile has been shown to simultaneously interact with the alkynyl group and iodine in a three-center transition state structure. ${ }^{24}$

The catalytic cycle is closed by TS5, releasing the final product $\mathbf{3 g}$ and regenerating free NHC A. Importantly, as $\mathbf{A}$ is not the most stable form of the catalyst, it is converted to the more favorable off-cycle resting state NHC-1. Overall, the total thermodynamics of the reaction is calculated to $59.9 \mathrm{kcal} / \mathrm{mol}$.

The mechanistic picture emerging from the calculations is in a full agreement with the results of experimental studies described in the previous section. First, the lowest energy pathway established for the $\mathrm{C}-\mathrm{C}$ bond formation, i.e., the direct $\mathrm{S}_{\mathrm{N}} 2$ substitution at $\alpha$-acetylenic carbon via 
TS4, explains the direct transfer of the ${ }^{13} \mathrm{C}$-label between iodonium salt $\mathbf{2} \mathbf{w}$ and product $\mathbf{3 a b}$ without swapping (Scheme 5). Secondly, the computed free energy profile is in line with the experimental rate-law (1). It correctly predicts that only the NHC precatalyst, the aldehyde, and TMEDA are involved in the turnover-limiting step, constituted by the largest energy span between NHC-1 and TS2 (overall $16.7 \mathrm{kcal} / \mathrm{mol}$ ). ${ }^{30}$ The height of this turnover-limiting barrier is also quantitatively consistent with the experimental rate of the reaction at $-40{ }^{\circ} \mathrm{C}$. Conversely, the iodonium salt enters the free energy profile within a lower barrier, later in the catalytic cycle (13.9 $\mathrm{kcal} / \mathrm{mol}$, D to TS4), thus, its concentration does not influence the overall rate.

\section{CONCLUSIONS}

In summary, we have developed an NHC-catalyzed direct $\mathrm{C}-\mathrm{H}$ alkynylation of aldehydes using alkynyliodonium salts as alkynyl donors, expanding the scope of the NHC organocatalysis. The proper choice the auxiliary aryl substituent secured the selective transfer of the alkynyl substituent from iodine, providing a facile entry to a variety of ynones in good to excellent yields. In particular, the method is well-suited for the synthesis of compounds bearing pharmaceutically relevant heterocyclic scaffolds. Due to the exceptionally mild reaction conditions, in terms of both the reaction temperature and the use of a weak amine base, a range of fragile functional groups is tolerated. Specifically, alkenes, alkynes, nitriles, ketones, esters, and amides can be incorporated into the products. Finally, the application of the organocatalyst in the combination with a hypervalent iodine reagent, allowed for a completely metal-free $\mathrm{C}-\mathrm{H}$ functionalization, rendering the developed reaction a green alternative for the preparation of propargylic ketones from abundant aldehyde starting materials. 
The mechanism of the reaction has been thoroughly studied by both experimental and computational methods. The ${ }^{13} \mathrm{C}$-labbeling and DFT calculations have shown that the alkynyl group transfer proceeds via a direct $\mathrm{S}_{\mathrm{N}} 2$ substitution of iodine by the Breslow intermediate occurring at $\alpha$-acetylenic carbon, and not by the prevalent pathway involving the initial attack of nucleophile at the $\beta$-position. This constitutes the second reported example of such a course of the alkynylation reaction with a hypervalent iodine reagent and, thus, the finding may implicate that analogous mechanisms can be more common than previously thought. Additionally, the kinetic studies, corroborated by the computed free energy profile, have identified the formation of Breslow intermediate to be the turnover-limiting step of the catalytic cycle. This demonstrates that the subsequent $\mathrm{C}-\mathrm{C}$ bond-forming reaction between the Breslow intermediate and the alkynyliodonium salt is a very facile, low-barrier process. Above result opens opportunities for the application of alkynyliodonium salts as efficient alkynyl-transfer reagents for other non-trivial nucleophilic species, including catalytically generated ones, in the future.

\section{ASSOCIATED CONTENT}

\section{Supporting Information:}

Experimental procedures, compound characterization data, NMR spectra of compounds $\mathbf{2} \mathbf{w}$ and 3a-3ab, details of kinetic investigations, computational details, free-energy profile for the reaction in $\mathrm{CHCl}_{3}$, calculated energies and energy corrections, optimized structures and Cartesian coordinates of stationary points (PDF).

\section{AUTHOR INFORMATION}

\section{Corresponding Author}


*E-mail: m.kalek@cent.uw.edu.pl

\section{ORCID}

Adam A. Rajkiewicz: 0000-0002-9550-6287

Marcin Kalek: 0000-0002-1595-9818

\section{Notes}

The authors declare no conflict of interest.

\section{ACKNOWLEDGMENT}

We acknowledge financial support from the National Science Centre, Poland (2014/15/D/ST5/02579). Computer time was generously provided by the Interdisciplinary Centre for Mathematical and Computational Modelling of the University of Warsaw (G75-0).

\section{REFERENCES}

1. (a) Moore, J. L.; Rovis, T. Top. Curr. Chem. 2010, 291, 77-144; (b) Bugaut, X.; Glorius, F. Chem. Soc. Rev. 2012, 41, 3511-3522; (c) Flanigan, D. M.; Romanov-Michailidis, F.; White, N. A.; Rovis, T. Chem. Rev. 2015, 115, 9307-9387; (d) Menon, R. S.; Biju, A. T.; Nair, V. Beilstein J. Org. Chem. 2016, 12, 444-461.

2. Biju, A. T.; Kuhl, N.; Glorius, F. Acc. Chem. Res. 2011, 44, 1182-1195.

3. (a) Yoshimura, A.; Zhdankin, V. V. Chem. Rev. 2016, 116, 3328-3435; (b) Hyatt, I. F. D.; Dave, L.; David, N.; Kaur, K.; Medard, M.; Mowdawalla, C. Org. Biomol. Chem. 2019, 17, $7822-7848$.

4. Yusubov, M. S.; Zhdankin, V. V. Curr. Org. Synth. 2012, 9, 247-272. 
5. Ghosh, M. K.; Rajkiewicz, A. A.; Kalek, M. Synthesis 2019, 51, 359-370.

6. (a) Toh, Q. Y.; McNally, A.; Vera, S.; Erdmann, N.; Gaunt, M. J. J. Am. Chem. Soc. 2013, 135, 3772-3775; (b) Rajkiewicz, A. A.; Kalek, M. Org. Lett. 2018, 20, 1906-1909; (c) Gelat, F.; Patra, A.; Pannecoucke, X.; Biju, A. T.; Poisson, T.; Besset, T. Org. Lett. 2018, 20, 38973901; (d) Yang, W.; Ma, D.; Zhou, Y.; Dong, X.; Lin, Z.; Sun, J. Angew. Chem. Int. Ed. 2018, $57,12097-12101$.

7. (a) Fawcett, C. H.; Firn, R. D.; Spencer, D. M. Physiol. Pl. Path. 1971, 1, 163-166; (b) Kundu, N. G.; Das, B.; Spears, C. P.; Majumdar, A.; Kang, S. I. J. Med. Chem. 1990, 33, 1975-1979; (c) Kundu, N. G.; Mahanty, J. S.; Spears, C. P. Bioorg. Med. Chem. Lett. 1996, 6, 1497-1502; (d) Quesnelle, C. A.; Gill, P.; Dodier, M.; St. Laurent, D.; Serrano-Wu, M.; Marinier, A.; Martel, A.; Mazzucco, C. E.; Stickle, T. M.; Barrett, J. F.; Vyas, D. M.; Balasubramanian, B. N. Bioorg. Med. Chem. Lett. 2003, 13, 519-524; (e) Kuklev, D. V.; Domb, A. J.; Dembitsky, V. M. Phytomedicine 2013, 20, 1145-1159.

8. Recent reviews: (a) Bagley, M. C.; Glover, C.; Merritt, E. A. Synlett 2007, 2459-2482; (b) Arai, T.; Ikematsu, Y.; Suemitsu, Y. Pure Appl. Chem. 2010, 82, 1485-1490; (c) Sengee, M.; Sydnes, L. K. Pure Appl. Chem. 2011, 83, 587-596; (d) Fraile, A.; Parra, A.; Tortosa, M.; Alemán, J. Tetrahedron 2014, 70, 9145-9173; (e) Abbiati, G.; Arcadi, A.; Marinelli, F.; Rossi, E. Synthesis 2014, 46, 687-721; (f) Whittaker, R. E.; Dermenci, A.; Dong, G. Synthesis 2016, $48,161-183$.

9. Selected examples: (a) Kel'i, A. V.; Gevorgyan, V. J. Org. Chem. 2002, 67, 95-98; (b) Silva, F.; Sawicki, M.; Gouverneur, V. Org. Lett. 2006, 8, 5417-5419; (c) D'Souza, D. M.; Müller, T. J. J. Nat. Protoc. 2008, 3, 1660-1665; (d) Willy, B.; Dallos, T.; Rominger, F.; Schönhaber, 
J.; Müller, T. J. J. Eur. J. Org. Chem. 2008, 4796-4805; (e) Zhao, T.; Xu, B. Org. Lett. 2010, 12, 212-215; (f) Zora, M.; Kivrak, A. J. Org. Chem. 2011, 76, 9379-9390; (g) Zhou, J.; Zhang, G.-L.; Zou, J.-P.; Zhang, W. Eur. J. Org. Chem. 2011, 3412-3415; (h) Xu, B.-H.; Kehr, G.; Fröhlich, R.; Wibbeling, B.; Schirmer, B.; Grimme, S.; Erker, G. Angew. Chem. Int. Ed. 2011, 50, 7183-7186; (i) Khong, S.; Kwon, O. J. Org. Chem. 2012, 77, 8257-8267; (j) Neumann, K. T.; Laursen, S. R.; Lindhardt, A. T.; Bang-Andersen, B.; Skrydstrup, T. Org. Lett. 2014, 16, 2216-2219; (k) Peng, S.; Wang, Z.; Zhang, L.; Zhang, X.; Huang, Y. Nat. Commun. 2018, 9, 375; (1) Li, J.; Yang, F.; Ma, Y.-T.; Ji, K. Adv. Synth. Catal. 2019, 361, 2148-2153.

10. (a) Vong, B. G.; Kim, S. H.; Abraham, S.; Theodorakis, E. A. Angew. Chem. Int. Ed. 2004, 43, 3947-3951; (b) Forsyth, C. J.; Xu, J.; Nguyen, S. T.; Samdal, I. A.; Briggs, L. R.; Rundberget, T.; Sandvik, M.; Miles, C. O. J. Am. Chem. Soc. 2006, 128, 15114-15116; (c) Nicolaou, K. C.; Sarlah, D.; Shaw, D. M. Angew. Chem. Int. Ed. 2007, 46, 4708-4711; (d) Tietze, L. F.; Singidi, R. R.; Gericke, K. M.; Böckemeier, H.; Laatsch, H. Eur. J. Org. Chem. 2007, 5875-5878.

11. Chinchilla, R.; Nájera, C. Chem. Rev. 2014, 114, 1783-1826.

12. For an alternative alkynylation of aldehydes, proceeding via an oxidative $\mathrm{C}-\mathrm{C}$ bond cleavage, see: Wang, Z.; Li, L.; Huang, Y. J. Am. Chem. Soc. 2014, 136, 12233-12236.

13. Ai, W.; Wu, Y.; Tang, H.; Yang, X.; Yang, Y.; Li, Y.; Zhou, B. Chem. Commun. 2015, 51, 7871-7874.

14. (a) Liu, X.; Yu, L.; Luo, M.; Zhu, J.; Wei, W. Chem. Eur. J. 2015, 21, 8745-8749; (b) Zhang, R.-Y.; Xi, L.-Y.; Zhang, L.; Chen, S.-Y.; Yu, X.-Q. Tetrahedron 2015, 71, 6176-6182; (c) 
Ouyang, X.-H.; Song, R.-J.; Wang, C.-Y.; Yang, Y.; Li, J.-H. Chem. Commun. 2015, 51, 14497-14500.

15. Mukherjee, S.; Garza-Sanchez, R. A.; Tlahuext-Aca, A.; Glorius, F. Angew. Chem. Int. Ed. 2017, 56, 14723-14726.

16. Reviews: (a) Zhdankin, V. V.; Stang, P. J. Tetrahedron 1998, 54, 10927-10966; (b) Yusubov, M. S.; Maskaev, A. V.; Zhdankin, V. V. Arkivoc 2011, 370-409; (c) Brand, J. P.; Waser, J. Chem. Soc. Rev. 2012, 41, 4165-4179.

17. Selected examples: (a) Lodaya, J. S.; Koser, G. F. J. Org. Chem. 1990, 55, 1513-1516; (b) Tykwinski, R. R.; Williamson, B. L.; Fischer, D. R.; Stang, P. J.; Arif, A. M. J. Org. Chem. 1993, 58, 5235-5237; (c) Liu, Z.; Chen, Z. J. Org. Chem. 1993, 58, 1924-1925; (d) Kitamura, T.; Tashi, N.; Tsuda, K.; Chen, H.; Fujiwara, Y. Heterocycles 2000, 52, 303-312; (e) Witulski, B.; Alayrac, C. Angew. Chem. Int. Ed. 2002, 41, 3281-3284; (f) Beringer, F. M.; Galton, S. A. J. Org. Chem. 1965, 30, 1930-1934; (g) Ochiai, M.; Ito, T.; Takaoka, Y.; Masaki, Y.; Kunishima, M.; Tani, S.; Nagao, Y. J. Chem. Soc., Chem. Commun. 1990, 118-119; (h) Kitamura, T.; Fukuoka, T.; Zheng, L.; Fujimoto, T.; Taniguchi, H.; Fujiwara, Y. Bull. Chem. Soc. Jpn. 1996, 69, 2649-2654; (i) Dhara, A.; Weinmann, J.; Krause, A.-M.; Beuerle, F. Chem. Eur. J. 2016, 22, 12473-12478; (j) Companys, S.; Peixoto, P. A.; Bosset, C.; Chassaing, S.; Miqueu, K.; Sotiropoulos, J.-M.; Pouységu, L.; Quideau, S. Chem. Eur. J. 2017, 23, 1330913313; a single example of C-nucleophile other than enolates of 1,3-dicarbonyls: (k) Finkbeiner, P.; Weckenmann, N. M.; Nachtsheim, B. J. Org. Lett. 2014, 16, 1326-1329;

18. (a) Kang, S.-K.; Lee, H.-W.; Jang, S.-B.; Ho, P.-S. Chem. Commun. 1996, 835-836; (b) Kang, S.-K.; Lim, K.-H.; Ho, P.-S.; Yoon, S.-K.; Son, H.-J. Synth. Commun. 1998, 28, 1481-1489; 
(c) Yu, C.-M.; Kweon, J.-H.; Ho, P.-S.; Kang, S.-C.; Lee, G. Y. Synlett 2005, 2631-2634; (d) Zhu, M.; Song, Y.; Cao, Y. Synthesis 2007, 853-856; (e) Guo, J.; Lin, L.; Liu, Y.; Li, X.; Liu, X.; Feng, X. Org. Lett. 2016, 18, 5540-5543.

19. Stuart, D. R. Chem. Eur. J. 2017, 23, 15852-15863.

20. Kitamura, T.; Stang, P. J. J. Org. Chem. 1988, 53, 4105-4106.

21. (a) Taylor, R. D.; MacCoss, M.; Lawson, A. D. G. J. Med. Chem. 2014, 57, 5845-5859; (b) Taylor, A. P.; Robinson, R. P.; Fobian, Y. M.; Blakemore, D. C.; Jones, L. H.; Fadeyi, O. Org. Biomol. Chem. 2016, 14, 6611-6637.

22. (a) Gillis, E. P.; Eastman, K. J.; Hill, M. D.; Donnelly, D. J.; Meanwell, N. A. J. Med. Chem. 2015, 58, 8315-8359; (b) Huchet, Q. A.; Kuhn, B.; Wagner, B.; Kratochwil, N. A.; Fischer, H.; Kansy, M.; Zimmerli, D.; Carreira, E. M.; Müller, K. J. Med. Chem. 2015, 58, 9041-9060; (c) Zhou, Y.; Wang, J.; Gu, Z.; Wang, S.; Zhu, W.; Aceña, J. L.; Soloshonok, V. A.; Izawa, K.; Liu, H. Chem. Rev. 2016, 116, 422-518.

23. (a) Norrby, P.-O.; Petersen, T. B.; Bielawski, M.; Olofsson, B. Chem. Eur. J. 2010, 16, 82518254; (b) Malmgren, J.; Santoro, S.; Jalalian, N.; Himo, F.; Olofsson, B. Chem. Eur. J. 2013, 19, 10334-10342; (c) Stridfeldt, E.; Lindstedt, E.; Reitti, M.; Blid, J.; Norrby, P.-O.; Olofsson, B. Chem. Eur. J. 2017, 23, 13249-13258; (d) Ghosh, M. K.; Rzymkowski, J.; Kalek, M. Chem. Eur. J. 2019, 25, 9619-9623.

24. (a) Frei, R.; Wodrich, M. D.; Hari, D. P.; Borin, P.-A.; Chauvier, C.; Waser, J. J. Am. Chem. Soc. 2014, 136, 16563-16573; (b) Wodrich, M. D.; Caramenti, P., Waser, J. Org. Lett. 2016, $18,60-63$. 
25. (a) Kitamura, T.; Stang, P. J. Tetrahedron Lett. 1988, 29, 1887-1889; (b) Ochiai, M.; Oshima, K.; Masaki, Y. Tetrahedron Lett. 1991, 32, 7711-7714; (c) Ochiai, M.; Kunishima, M.; Tani, S.; Nagao, Y. J. Am. Chem. Soc. 1991, 113, 3135-3142; (d) Ochiai, M.; Kitagawa, Y.; Yamamoto, S. J. Am. Chem. Soc. 1997, 119, 11598-11604.

26. (a) Ochiai, M.; Kunishima, M.; Nagao, Y.; Fuji, K.; Shiro, M.; Fujita, E. J. Am. Chem. Soc. 1986, 108, 8281-8283; (b) Tykwinski, R. R.; Whiteford, J. A.; Stang, P. J. J. Chem. Soc., Chem. Commun. 1993, 1800-1801; (c) Williamson, B. L.; Tykwinski, R. R.; Stang, P. J. J. Am. Chem. Soc. 1994, 116, 93-98; (d) Feldman, K. S.; Saunders, J. C.; Wrobleski, M. L. J. Org. Chem. 2002, 67, 7096-7109.

27. Fernández González, D.; Brand, J. P.; Waser, J. Chem. Eur. J. 2010, 16, 9457-9461.

28. The data points did not show linear dependence in the coordinate systems corresponding to the 1st and 3rd overall orders. See the Supporting Information for details.

29. We have also calculated the full mechanism in $\mathrm{CHCl}_{3}$, the solvent that was used in the initial rate studies. The overall mechanistic picture and conclusions are identical to these obtained for the calculations in toluene. See the Supporting Information for details.

30. The computed free energy profile predicts that the conjugated acid of TMEDA should inhibit the reaction, as it is expelled within the largest energy span. This should in turn result in the overall first order during the time-course experiment, instead of the observed second order (Figure 1). However, under the experimental conditions (toluene, $-40^{\circ} \mathrm{C}$ ) the salts of TMEDA are insoluble, hence, their concentrations remain constant, lacking the impact on the kinetics of the reaction. 
SYNOPSIS

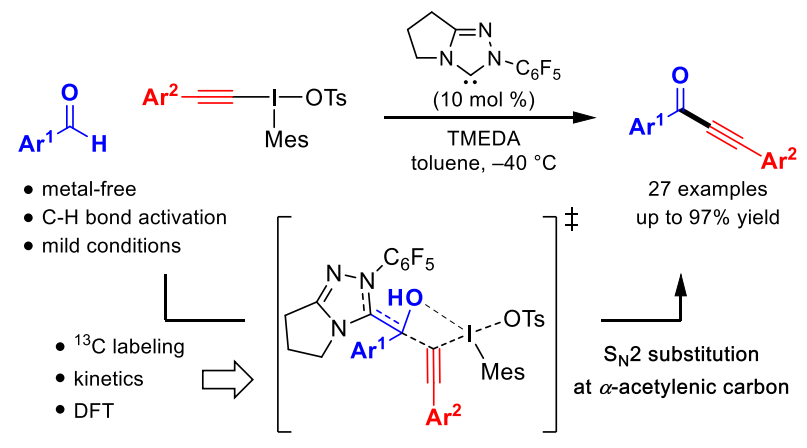




\title{
SUPPORTING INFORMATION
}

\section{$N$-Heterocyclic Carbene-Catalyzed Synthesis of Ynones via C-H Alkynylation of Aldehydes with Alkynyliodonium Salts}

\author{
Adam A. Rajkiewicz, ${ }^{\dagger+}$ Natalia Wojciechowska ${ }^{\dagger, \ddagger}$ and Marcin Kalek ${ }^{*}, \dagger$ \\ ${ }^{\dagger}$ Centre of New Technologies, University of Warsaw, Banacha 2C, 02-097 Warsaw, Poland \\ ${ }^{\ddagger}$ Faculty of Chemistry, University of Warsaw, Pasteura 1, 02-093 Warsaw, Poland \\ *E-mail: m.kalek@cent.uw.edu.pl
}

Table of Contents

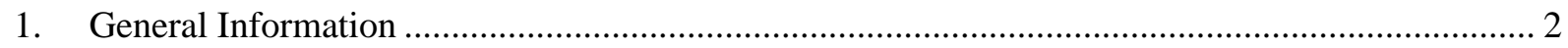

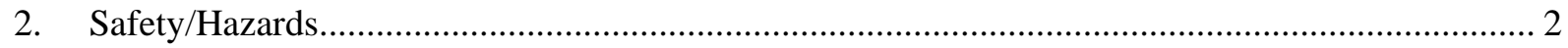

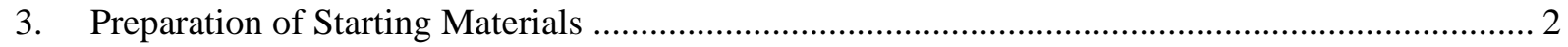

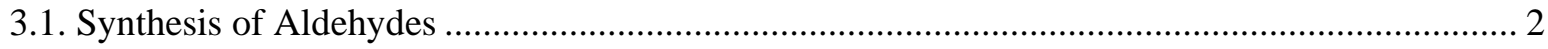

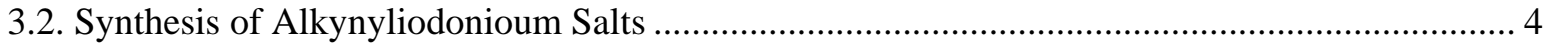

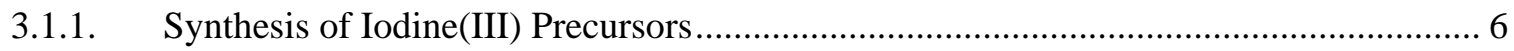

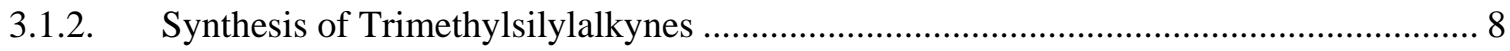

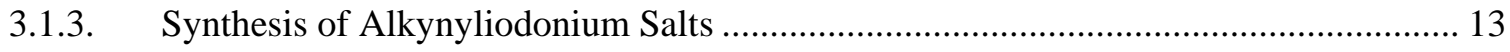

3.1.4. Synthesis of [2-phenyl $\left(1-{ }^{13} C\right)$ ethynyl](2,4,6-trimethylphenyl) iodonium $p$ -

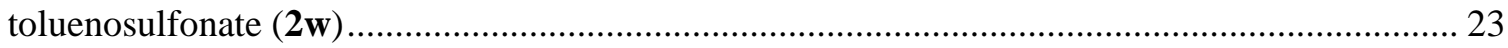

4. NHC-Catalyzed Propargylation of Aldehydes with Alkynyliodonium Salts ............................... 25

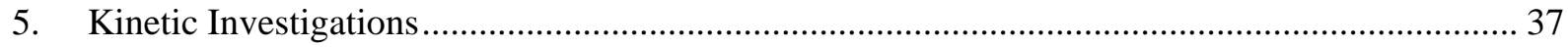

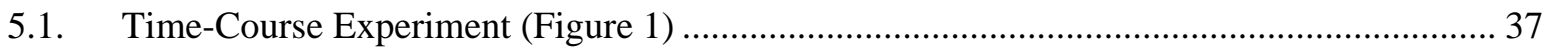

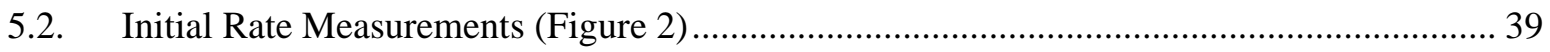

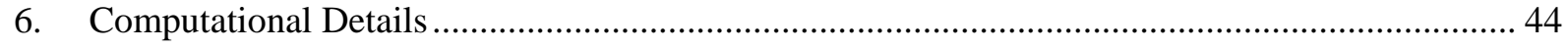

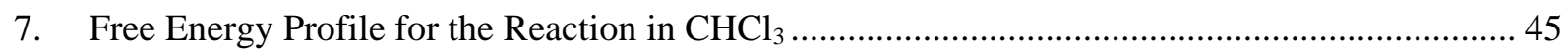

8. Energies and Energy Corrections of Stationary Points (in atomic units) ...................................... 45

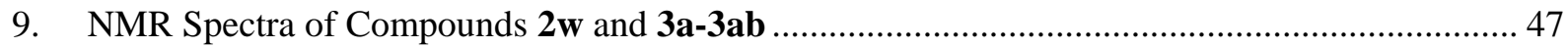

10. Structures and Cartesian Coordinates of Stationary Points ........................................................ 78 


\section{General Information}

Unless otherwise noted, all materials were purchased from commercial suppliers and used as received. Anhydrous $\mathrm{CH}_{2} \mathrm{Cl}_{2}$, THF, and toluene were purified prior to use by passage through a column of neutral alumina under nitrogen. Triethylamine and water were degassed using freeze-pump-thaw method and kept in glovebox (triethylamine over molecular sieves $4 \AA$ ). Catalysts precursors NHC-1, ${ }^{1}$ NHC-2, ${ }^{2}$ NHC-3,${ }^{2}$ NHC-4, ${ }^{3}$ NHC-6, ${ }^{4}$ NHC-7, ${ }^{5}$ and NHC-9 ${ }^{5}$ were synthesized according to published procedures.

${ }^{1} \mathrm{H},{ }^{13} \mathrm{C}$, and ${ }^{19} \mathrm{~F}$ spectroscopic data were collected on Varian $400 \mathrm{MHz}$ and Bruker $500 \mathrm{MHz}$ spectrometers at ambient temperature. The chemical shifts are reported in ppm relative to solvent peaks. Assignment of the NMR signals of products 3a-3ab was accomplished on the basis of 2D correlation experiments (atom-labeling scheme is arbitrary). Mass spectra were recorded on Thermo QExactive mass spectrometer. IR spectra were recorded on Shimadzu IRPrestige-21 FT-IR spectrometer with ATR attachment.

\section{Safety/Hazards}

During an attempted synthesis of (2-phenylethynyl)(2,4,6-trimethylphenyl)iodonium hexafluoroarsenate a sample of compound dried in vacuo violently decomposed upon touching it with a stainless-steel spatula. We recommend exercising special care during the preparation of this and similar alkynyliodonium salts containing very weakly-coordinating anions.

\section{Preparation of Starting Materials}

The yields in this section have not been optimized.

\subsection{Synthesis of Aldehydes}

Aldehydes $\mathbf{1} \mathbf{j}, \mathbf{1 k}$, and $\mathbf{1} \mathbf{l}$ have been synthesized according to the following procedures.

\section{Scheme S1.}<smiles>O=Cc1ccc(Br)cn1</smiles>

$1 \mathrm{i}$<smiles>Oc1ccccc1C(F)(F)F</smiles>

1.1 equiv.

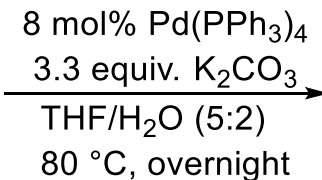

$80^{\circ} \mathrm{C}$, overnight<smiles>O=Cc1ccc(-c2ccccc2C(F)(F)F)cn1</smiles>

$1 \mathrm{j}$

\footnotetext{
${ }^{1}$ Vora, H. U.; Lathrop, S. P.; Reynolds, N. T.; Kerr, M. S.; Read de Alaniz, J.; Rovis, T. Org. Synth. 2010, 87, 350.

${ }^{2}$ Davidson, R. W. M; Fuchter, M. K. Chem. Commun. 2016, 52, 11638-11641.

${ }^{3}$ Kretschmer, M.; Dieckmann, M.; Li, P.; Rudolph, S.; Herkommer, D.; Troendlin, J.; Menche, D. Chem. Eur. J. 2013, 19, 15993-16018.

${ }^{4}$ Wilde, M. M.; Gravel, M. Angew. Chem. Int. Ed. 2013, 52, 12651-12654.

${ }^{5}$ Piel, I.; Pawelczyk, M. D.; Hirano, K.; Fröhlich, R.; Glorius, F. Eur. J. Org. Chem. 2011, 5475-5484.
} 
5-[2-(trifluoromethyl)phenyl]pyridine-2-carbaldehyde (1j). ${ }^{6}$ In a nitrogen-atmosphere glovebox, a pressure ampoule was charged with 5-bromo-2-pyridinecarboxaldehyde (949 mg, $5.0 \mathrm{mmol}), \mathrm{Pd}\left(\mathrm{PPh}_{3}\right)_{4}$ (472 mg, $0.4 \mathrm{mmol}$ ), and $\mathrm{K}_{2} \mathrm{CO}_{3}(2.28 \mathrm{~g}, 16.5 \mathrm{mmol}$ ). THF (anhydrous, $25 \mathrm{~mL}$ ) and water (degassed, $10 \mathrm{~mL}$ ) were added. Next, 2-(trifluoromethyl)phenylboronic acid $(1.05 \mathrm{~g}, 5.5 \mathrm{mmol})$ was added in one portion and the ampoule was closed, removed from the glovebox, and stirred at $80{ }^{\circ} \mathrm{C}$ overnight. After cooling to room temperature, water $(20 \mathrm{~mL})$ was added and the resulting mixture was extracted with AcOEt $(3 \times 20 \mathrm{~mL})$. Combined organic phases were washed with brine $(30 \mathrm{~mL})$, dried over anhydrous $\mathrm{MgSO}_{4}$, filtered, and concentrated under reduced pressure. The product was purified by column chromatography (silica, petroleum ether:ethyl acetate/9:1 to 8:2) and it was obtained as a yellow solid (1.13 g, 90\% yield). ${ }^{1} \mathrm{H}$ NMR $\left(400 \mathrm{MHz}, \mathrm{CDCl}_{3}\right): \delta 10.15(\mathrm{~d}, J=0.8 \mathrm{~Hz}, 1 \mathrm{H}), 8.75(\mathrm{~d}, J=2.1 \mathrm{~Hz}, 1 \mathrm{H})$, $8.03(\mathrm{dd}, J=8.0,0.8 \mathrm{~Hz}, 1 \mathrm{H}), 7.86(\mathrm{ddd}, J=8.0,1.5,0.7 \mathrm{~Hz}, 1 \mathrm{H}), 7.84-7.81(\mathrm{~m}, 1 \mathrm{H}), 7.69-7.55(\mathrm{~m}$, $2 \mathrm{H}), 7.37-7.32(\mathrm{~m}, 1 \mathrm{H}) .{ }^{19} \mathrm{~F} \mathrm{NMR}\left(376 \mathrm{MHz}, \mathrm{CDCl}_{3}\right): \delta-56.7(\mathrm{~s})$. The spectral data are in accordance with literature. ${ }^{6}$

\section{Scheme S2.}

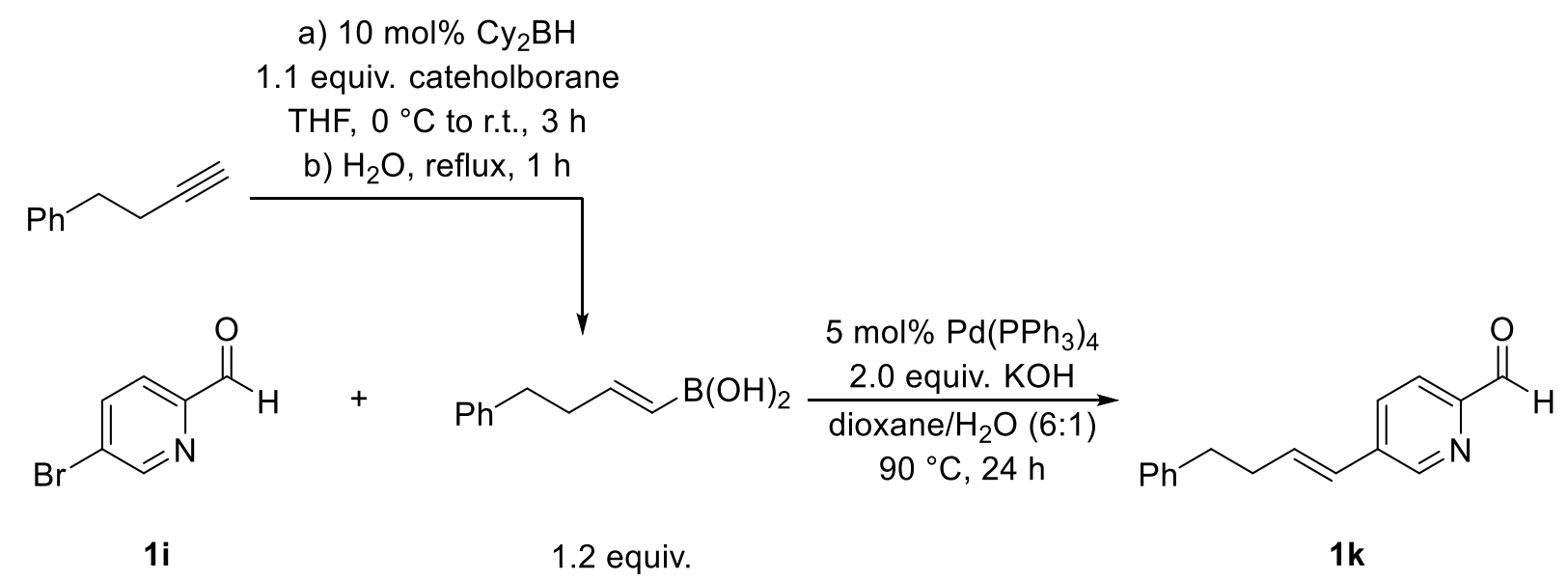

[(1E)-4-phenylbut-1-en-1-yl]boronic acid. ${ }^{7}$ An oven-dried round bottom flask was capped with semptum and evacuated/back-filled with nitrogen 3 times. Solution of borane-THF complex in THF (1 $\mathrm{M}, 2.0 \mathrm{~mL}, 2.0 \mathrm{mmol}$ ) was added via syringe, the flask was cooled down to $0{ }^{\circ} \mathrm{C}$, and cyclohexene (413 $\mu \mathrm{L}, 4.0 \mathrm{mmol}$ ) was added. The resulting mixture was stirred at $0{ }^{\circ} \mathrm{C}$ for $45 \mathrm{~min}$ (within this time a precipitate of dicyclohexylborane appeared). Next, 4-phenyl-1-butyne $(2.9 \mathrm{~mL}, 20 \mathrm{mmol})$ and solution of catecholborane in THF $(1 \mathrm{M}, 22 \mathrm{~mL}, 22 \mathrm{mmol})$ were added at $0{ }^{\circ} \mathrm{C}$. The cooling bath was removed and the reaction mixture was stirred at room temperature for $2 \mathrm{~h}$. The volatiles were removed under reduced pressure, water $(20 \mathrm{~mL})$ was added to the residue, and the mixture was heated to reflux for $1 \mathrm{~h}$. After cooling to room temperature, the resulting mixture was kept for $1 \mathrm{~h}$ at $4{ }^{\circ} \mathrm{C}$. The precipitated solid was filtrated, washed with water $(3 \times 20 \mathrm{~mL})$, petroleum ether $(2 \times 20 \mathrm{~mL})$, and dried under high vacuum. The product was obtained as a white solid $(2.31 \mathrm{~g}, 67 \%$ yield $)$.

${ }^{1} \mathrm{H}$ NMR $\left(400 \mathrm{MHz}, \mathrm{CDCl}_{3}\right) \delta 7.33-7.27(\mathrm{~m}, 2 \mathrm{H}), 7.24-7.17(\mathrm{~m}, 3 \mathrm{H}), 7.02(\mathrm{dt}, J=17.7,6.3 \mathrm{~Hz}, 1 \mathrm{H})$, $5.60(\mathrm{~d}, J=17.7 \mathrm{~Hz}, 1 \mathrm{H}), 2.82-2.73(\mathrm{~m}, 2 \mathrm{H}), 2.59-2.47(\mathrm{~m}, 2 \mathrm{H})$. The spectral data are in accordance with literature. ${ }^{8}$

\footnotetext{
${ }^{6}$ Charoensutthivarakul, S.; David Hong, W.; Leung, S. C.; Gibbons, P. D.; Bedingfield, P. T. P.; Nixon, G. L.; Lawrenson, A. S.; Berry, N. G.; Ward, S. A.; Biagini, G. A.; O'Neill, P. M. Med. Chem. Commun. 2015, 6, 1252-1259.

${ }^{7}$ The procedure is a modified version of the procedure given in: Shirakawa, K.; Arase, A.; Hoshi, M. Synthesis 2004, 1814-1820.

${ }^{8}$ Molander, G. A.; Cavalcanti, L. N.; Canturk, B.; Pan, P.-S.; Kennedy, L. E. J. Org. Chem. 2009, 74, 7364-7369.
} 
5-[(1E)-4-phenylbut-1-en-1-yl]pyridine-2-carbaldehyde (1k). ${ }^{9}$ In a nitrogen-atmosphere glovebox, a pressure ampoule was charged with 5-bromo-2-pyridinecarboxaldehyde (949 mg, $5.0 \mathrm{mmol}), \mathrm{Pd}\left(\mathrm{PPh}_{3}\right)_{4}$ (295 mg, $0.25 \mathrm{mmol})$, [(1E)-4-phenylbut-1-en-1-yl]boronic acid (1.06 g, $6.0 \mathrm{mmol})$, and $\mathrm{KOH}(561 \mathrm{mg}$, $10.0 \mathrm{mmol}$ ). Next, 1,4-dioxane (anhydrous, $51 \mathrm{~mL}$ ) and water (degassed, $8.5 \mathrm{~mL}$ ) were added. The ampoule was closed, removed from the glovebox, and stirred at $90{ }^{\circ} \mathrm{C}$ for $24 \mathrm{~h}$. After cooling to room temperature, water $(40 \mathrm{~mL})$ was added and the resulting mixture was extracted with AcOEt $(3 \times 50 \mathrm{~mL})$. Combined organic phases were dried over anhydrous $\mathrm{MgSO}_{4}$, filtered, and concentrated under reduced pressure. The product was purified by column chromatography (silica, petroleum ether:ethyl acetate/9:1 to 8:2) and it was obtained as a yellow solid (463 mg, 39\% yield). ${ }^{1} \mathrm{H}$ NMR (400 $\left.\mathrm{MHz}, \mathrm{CDCl}_{3}\right) \delta 10.04$ $(\mathrm{d}, J=0.8 \mathrm{~Hz}, 1 \mathrm{H}), 8.69(\mathrm{~d}, J=1.8 \mathrm{~Hz}, 1 \mathrm{H}), 7.90(\mathrm{dd}, J=8.1,0.6 \mathrm{~Hz}, 1 \mathrm{H}), 7.79(\mathrm{dd}, J=8.1,2.1 \mathrm{~Hz}$, $1 \mathrm{H}), 7.34-7.28(\mathrm{~m}, 2 \mathrm{H}), 7.24-7.19(\mathrm{~m}, 3 \mathrm{H}), 6.56-6.42(\mathrm{~m}, 2 \mathrm{H}), 2.87-2.80(\mathrm{~m}, 2 \mathrm{H}), 2.62$ (ddd, $J=$ 9.5, 7.3, 6.1 Hz, 2H).

\section{Scheme S3.}

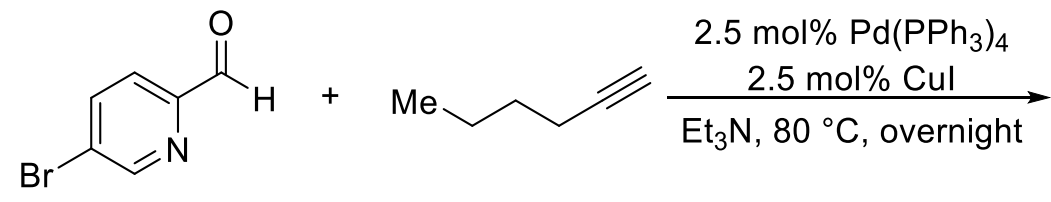

$1 \mathrm{i}$

1.5 equiv.<smiles>CCCCC#Cc1ccc(C=O)nc1</smiles>

11

5-(hex-1-yn-1-yl)pyridine-2-carbaldehyde (11). ${ }^{10}$ In a nitrogen-atmosphere glovebox, $20 \mathrm{~mL}$ ovendried vial was charged with 5-bromo-2-pyridinecarboxaldehyde (569 mg, $3.0 \mathrm{mmol}), \mathrm{Pd}\left(\mathrm{PPh}_{3}\right)_{4}(88.4$ $\mathrm{mg}, 0.075 \mathrm{mmol}$ ), and $\mathrm{CuI}(14.3 \mathrm{mg}, 0.075 \mathrm{mmol})$. Next, $\mathrm{Et}_{3} \mathrm{~N}$ (degassed, $40 \mathrm{~mL}$ ) was added, followed by the addition of 1-hexyne $(531 \mu \mathrm{L}, 4.5 \mathrm{mmol})$. The vial was capped, removed from the glovebox, and stirred at $80^{\circ} \mathrm{C}$ overnight. After cooling to room temperature, the reaction mixture was transferred to a $100 \mathrm{~mL}$ round-bottom flask using $\mathrm{CH}_{2} \mathrm{Cl}_{2}$ and volatiles were removed under reduced pressure. Next, $\mathrm{Et}_{2} \mathrm{O}(50 \mathrm{~mL})$ was added, causing the formation of triethylammonium bromide precipitate, which was removed by passing the mixture through a short pad of silica using $\mathrm{Et}_{2} \mathrm{O}$. Collected filtrate was concentrated under reduced pressure and the product was purified by column chromatography (silica, petroleum ether:ethyl acetate/95:5 to 90:10). The product was obtained as a brownish oil, which solidified when kept at $4{ }^{\circ} \mathrm{C}\left(490 \mathrm{mg}, 87 \%\right.$ yield). ${ }^{1} \mathrm{H}$ NMR $\left(400 \mathrm{MHz}, \mathrm{CDCl}_{3}\right) \delta 10.05(\mathrm{~d}, J=0.8 \mathrm{~Hz}$, $1 \mathrm{H}), 8.74(\mathrm{dd}, J=1.9,0.8 \mathrm{~Hz}, 1 \mathrm{H}), 7.88(\mathrm{dd}, J=8.0,0.9 \mathrm{~Hz}, 1 \mathrm{H}), 7.82(\mathrm{ddd}, J=8.0,2.0,0.8 \mathrm{~Hz}, 1 \mathrm{H})$, $2.47(\mathrm{t}, J=7.1 \mathrm{~Hz}, 2 \mathrm{H}), 1.66-1.58(\mathrm{~m}, 2 \mathrm{H}), 1.54-1.44(\mathrm{~m}, 2 \mathrm{H}), 0.96(\mathrm{t}, J=7.3 \mathrm{~Hz}, 3 \mathrm{H})$.

\subsection{Synthesis of Alkynyliodonioum Salts}

1-(Phenylethynyl)-1,2-benziodoxol-3(1H)-one 4 was synthesized according to the following sequence:

\footnotetext{
${ }^{9}$ The procedure is a modified version of the procedure given in: Piala, A.; Mayi, D.; Handy, S. T. Tetrahedron 2011, 67, 4147-4154.

${ }^{10}$ The procedure is a modified version of the procedure given in: Musso, D. L.; Clarke, M. J.; Kelley, J. L.; Boswelld, G. E.; Chena G. Org. Biomol. Chem. 2003, 1, 498-506.
} 


\section{Scheme S4.}
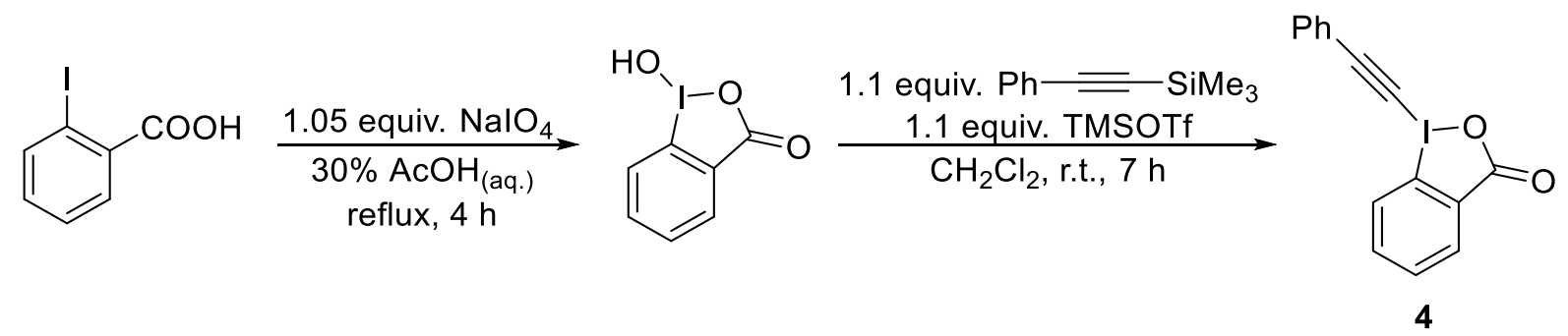

1-Hydroxy-1,2-benziodoxol-3-(1H)-one. ${ }^{11} \mathrm{NaIO}_{4}(5.65 \mathrm{~g}, 26.4 \mathrm{mmol})$ and 2-iodobenzoic acid (6.24 g, $25.2 \mathrm{mmol})$ were suspended in aqueous $\mathrm{AcOH}(30 \% \mathrm{v}: \mathrm{v}, 48 \mathrm{~mL})$. The mixture was vigorously stirred and refluxed for $4 \mathrm{~h}$. The reaction mixture was then diluted with cold water $(20 \mathrm{~mL})$ and allowed to cool to room temperature, protecting it from light. After $1 \mathrm{~h}$, the product was collected by filtration, washed with ice water $(3 \times 5 \mathrm{~mL})$ and acetone $(3 \times 5 \mathrm{~mL})$. After drying in air in the dark, the product was obtained as a colorless solid (6.28 g, $95 \%$ yield).

1-(Phenylethynyl)-1,2-benziodoxol-3(1H)-one (4). ${ }^{12}$ Under nitrogen atmosphere, TMSOTf $(2.0 \mathrm{~mL}$, $11 \mathrm{mmol}$ ) was added via syringe to stirred suspension of 1-hydroxy-1,2-benziodoxol-3-(1H)-one (2.64 $\mathrm{g}, 10 \mathrm{mmol}$ ) in $\mathrm{CH}_{2} \mathrm{Cl}_{2}$ (anhydrous, $25 \mathrm{~mL}$ ) at room temperature. The resulting yellow mixture was stirred for $1 \mathrm{~h}$, followed by the addition of trimethyl(2-phenylethynyl)silane $(1.92 \mathrm{~g}, 11 \mathrm{mmol})$. After stirring at room temperature overnight, saturated aqueous $\mathrm{NaHCO}_{3}(50 \mathrm{~mL})$ was added and the mixture was stirred vigorously for another $30 \mathrm{~min}$. Organic phase was separated and washed once with saturated aqueous $\mathrm{NaHCO}_{3}(50 \mathrm{~mL})$, then dried over anhydrous $\mathrm{MgSO}_{4}$, filtered, and concentrated under reduced pressure. The residue treated with $\mathrm{Et}_{2} \mathrm{O}(25 \mathrm{~mL})$ causing the precipitation of solid, which was filtered off and washed with a small amount of $\mathrm{Et}_{2} \mathrm{O}(2 \times 5 \mathrm{~mL})$. After drying under high vacuum, the product was obtained as a colorless solid $\left(2.35 \mathrm{~g}, 67 \%\right.$ yield). ${ }^{1} \mathrm{H}$ NMR $\left(400 \mathrm{MHz}, \mathrm{CDCl}_{3}\right) \delta 8.46-8.40(\mathrm{~m}$, $1 \mathrm{H}), 8.29-8.22(\mathrm{~m}, 1 \mathrm{H}), 7.81-7.74(\mathrm{~m}, 2 \mathrm{H}), 7.63-7.59(\mathrm{~m}, 2 \mathrm{H}), 7.53-7.41(\mathrm{~m}, 3 \mathrm{H})$. The spectral data are in accordance with literature. ${ }^{12}$

Alkynyliodonium salts were synthesized in a sequence of reactions shown in Scheme S5.

\section{Scheme S5. ${ }^{a}$}

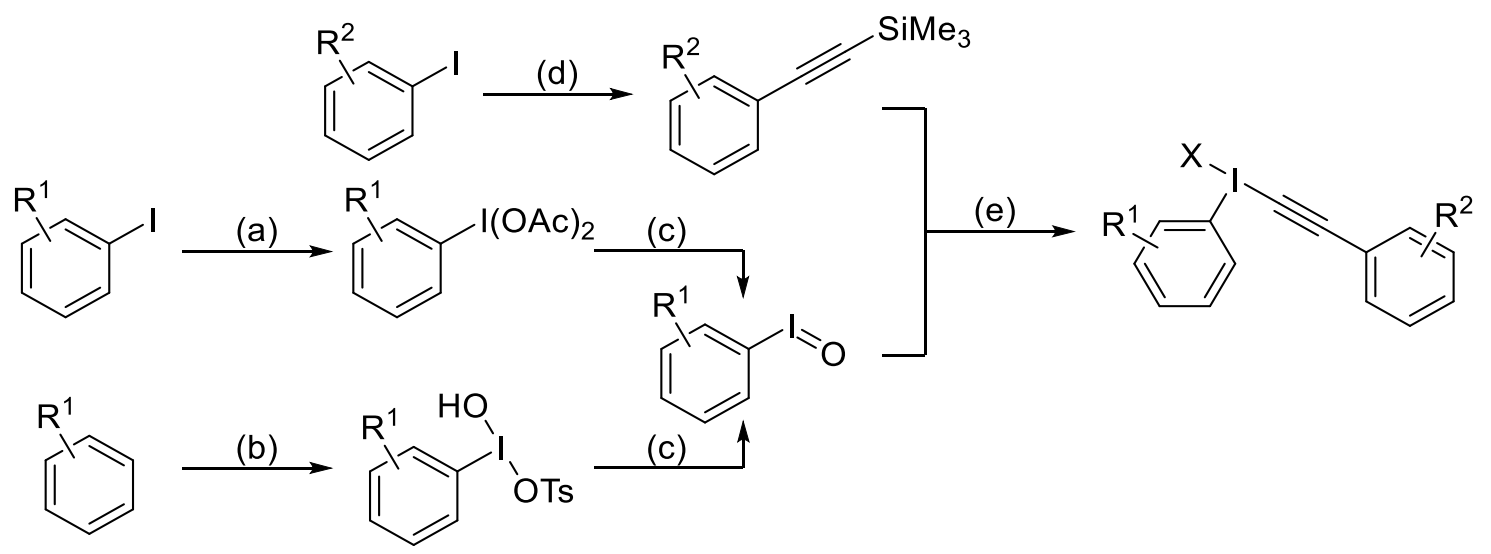

\footnotetext{
${ }^{11}$ Kraszkiewicz, L.; Skulski, L. Arkivoc 2003, 6, 120-125.

${ }^{12}$ Huang, H.; Zhang, G.; Chen, Y. Angew. Chem. Int. Ed. 2015, 54, 7872-7876.
} 
${ }^{a}$ Reagents and conditions: (a) $\mathrm{NaBO}_{3} \cdot 4 \mathrm{H}_{2} \mathrm{O}, \mathrm{AcOH}, 45^{\circ} \mathrm{C}, 16 \mathrm{~h}$; (b) $\mathrm{I}_{2}, m$-CPBA, TsOH, $\mathrm{CH}_{2} \mathrm{Cl}_{2}$, r.t., overnight; (c) $3 \mathrm{M} \mathrm{NaOH}_{\text {(aq.) }}$, r.t., 1 h; (d) $\mathrm{Pd}\left(\mathrm{PPh}_{3}\right)_{4}, \mathrm{CuI}, \mathrm{Et}_{3} \mathrm{~N}, 80^{\circ} \mathrm{C}$, overnight; (e) $\mathrm{BF}_{3} \cdot \mathrm{Et}_{2} \mathrm{O}, \mathrm{CH}_{2} \mathrm{Cl}_{2}$, $0{ }^{\circ} \mathrm{C}$ to r.t., overnight; followed by $\mathrm{NaX}, \mathrm{H}_{2} \mathrm{O}, \mathrm{rt}, 30 \mathrm{~min}$.

\subsubsection{Synthesis of Iodine(III) Precursors}<smiles>Cc1ccccc1C(C)(C)C</smiles>

2-Methyl(diacetoxyiodo)benzene. ${ }^{13} \mathrm{NaBO}_{3} \cdot 4 \mathrm{H}_{2} \mathrm{O}(33.85 \mathrm{~g}, 220 \mathrm{mmol})$ was added portion-wise to the stirred solution of 2-iodotoluene $(2.55 \mathrm{~mL}, 20 \mathrm{mmol})$ in acetic acid $(170 \mathrm{~mL})$ at $45^{\circ} \mathrm{C}$ over $1 \mathrm{~h}$ period. After stirring for additional $16 \mathrm{~h}$ at $45^{\circ} \mathrm{C}$, the reaction mixture was cooled to room temperature and concentrated under reduced pressure. Water $(170 \mathrm{~mL})$ was added and the resulting mixture was extracted with $\mathrm{CH}_{2} \mathrm{Cl}_{2}(3 \times 100 \mathrm{~mL})$. The combined organic layers were dried over anhydrous $\mathrm{Na}_{2} \mathrm{SO}_{4}$, filtered, and concentrated under reduced pressure. $\mathrm{Et}_{2} \mathrm{O}(100 \mathrm{~mL})$ was added to the residue, and the precipitated product was filtered and washed with $\mathrm{Et}_{2} \mathrm{O}$. After drying under high vacuum, the product was obtained as a white solid $\left(4.37 \mathrm{~g}, 65 \%\right.$ yield). ${ }^{1} \mathrm{H}$ NMR $\left(400 \mathrm{MHz}, \mathrm{CDCl}_{3}\right): \delta 8.19-8.14(\mathrm{~m}, 1 \mathrm{H}), 7.55-7.48$ $(\mathrm{m}, 2 \mathrm{H}), 7.28-7.22(\mathrm{~m}, 1 \mathrm{H}), 2.72(\mathrm{~s}, 3 \mathrm{H}), 1.98(\mathrm{~s}, 6 \mathrm{H})$. The spectral data are in accordance with literature. ${ }^{14}$<smiles>Cc1cccc(C)c1OC(C)(C)C</smiles>

2,6-Dimethyl(diacetoxyiodo)benzene. The title compound was prepared from 2-iodo-2,6dimethylbenzene in $30 \mathrm{mmol}$ scale, following the same procedure as for 2methyl(diacetoxyiodo)benzene. The product was obtained as a white solid ( $3.54 \mathrm{~g}, 34 \%$ yield). ${ }^{1} \mathrm{H}$ NMR $\left(400 \mathrm{MHz}, \mathrm{CDCl}_{3}\right) \delta 7.38(\mathrm{dd}, J=8.3,6.6 \mathrm{~Hz}, 1 \mathrm{H}), 7.29(\mathrm{~d}, J=7.7 \mathrm{~Hz}, 2 \mathrm{H}), 2.75(\mathrm{~s}, 6 \mathrm{H}), 1.97(\mathrm{~s}, 6 \mathrm{H})$. The spectral data are in accordance with literature. ${ }^{15}$<smiles>COc1ccccc1Cl</smiles>

2-Methoxy(diacetoxyiodo)benzene. The title compound was prepared from 2-iodoanisole in $55 \mathrm{mmol}$ scale, following the same procedure as for 2-methyl(diacetoxyiodo)benzene. The product was obtained as a white solid (10.8 g, $56 \%$ yield). ${ }^{1} \mathrm{H} \mathrm{NMR}\left(400 \mathrm{MHz}, \mathrm{CDCl}_{3}\right): \delta 8.14(\mathrm{dd}, J=7.9,1.6 \mathrm{~Hz}, 1 \mathrm{H}), 7.58$ (ddd, $J=8.4,7.4,1.6 \mathrm{~Hz}, 1 \mathrm{H}$ ), 7.15 (dd, $J=8.4,1.3 \mathrm{~Hz}, 1 \mathrm{H}$ ), 7.03 (ddd, $J=7.9,7.4,1.3 \mathrm{~Hz}, 1 \mathrm{H}$ ), 3.98 $(\mathrm{s}, 3 \mathrm{H}), 1.97(\mathrm{~s}, 6 \mathrm{H})$. The spectral data are in accordance with literature. ${ }^{14}$<smiles>Cc1cc(C)c(C(C)(C)C)c(C)c1</smiles>

\footnotetext{
${ }^{13}$ The procedure is a modified version of the procedure given in: Carroll, M. A.; Nairne, J.; Smith, G.; Widdowson, D. A. J. Fluor. Chem. 2007, 128, 127-132.

${ }^{14}$ Rajkiewicz, A. A.; Kalek, M. Org. Lett. 2018, 20, $1906-1909$.

${ }^{15}$ Lucchetti, N.; Gilmour, R. Chem. Eur. J. 2018, 24, 16266-16270.
} 
2,4,6-Trimethyl(diacetoxyiodo)benzene. The title compound was prepared from 2-iodo-1,3,5trimethylbenzene in $8 \mathrm{mmol}$ scale, following the same procedure as for 2methyl(diacetoxyiodo)benzene. The product was obtained as a white solid (1.93 g, 66\% yield). ${ }^{1} \mathrm{H}$ NMR $\left(400 \mathrm{MHz}, \mathrm{CDCl}_{3}\right): \delta 7.10(\mathrm{~d}, J=0.5 \mathrm{~Hz}, 2 \mathrm{H}), 2.70(\mathrm{~s}, 6 \mathrm{H}), 2.35(\mathrm{~s}, 3 \mathrm{H}), 1.96(\mathrm{~s}, 6 \mathrm{H})$.<smiles>Cc1cc(C)c(I(O)O)c(C)c1</smiles>

1-[Hydroxy(tosyloxy)iodo]-2,4,6-trimethylbenzene. ${ }^{16} 500 \mathrm{~mL}$ round-bottom flask was charged with fine-grinded iodine $(9.01 \mathrm{~g}, 35.5 \mathrm{mmol})$, then $\mathrm{CH}_{2} \mathrm{Cl}_{2}(250 \mathrm{~mL})$ was added. Resulting mixture was stirred for $15 \mathrm{~min}$. at room temperature until iodine dissolved completely. Next, mesitylene $(10.0 \mathrm{~mL}$, $71 \mathrm{mmol}$ ), $m$-CPBA (70\% of active oxidant, dried under high vacuum for $1 \mathrm{~h} ; 26.3 \mathrm{~g}, 107 \mathrm{mmol}$ ), and $p$-toluenesulfonic acid monohydrate $(13.5 \mathrm{~g}, 71 \mathrm{mmol})$ were sequentially added. The reaction mixture was stirred at room temperature overnight (after c.a. 15 minutes of stirring the color of the reaction mixture started to change from deep purple to bright yellow, also a precipitate appeared). The reaction mixture was concentrated under reduced pressure and $\mathrm{Et}_{2} \mathrm{O}(250 \mathrm{~mL})$ was added to the residue. The resulting mixture was stirred vigorously at room temperature for $1 \mathrm{~h}$. Precipitated solid was filtered off, washed with $\mathrm{Et}_{2} \mathrm{O}(3 \times 100 \mathrm{~mL})$ and dried under high vacuum providing the product as a white powder (30.0 g, 97\% yield). ${ }^{1} \mathrm{H}$ NMR (400 MHz, $\left.\mathrm{CD}_{3} \mathrm{CN}\right) \delta 7.30-7.26(\mathrm{~m}, 2 \mathrm{H}), 7.12-7.07(\mathrm{~m}, 2 \mathrm{H}), 2.32$ (s, $6 \mathrm{H}), 2.31(\mathrm{~s}, 6 \mathrm{H})$. The spectral data are in accordance with literature. ${ }^{17}$<smiles>O=Ic1ccccc1</smiles>

Iodosylbenzene. ${ }^{18}$ Round-bottom flask was charged with (diacetoxyiodo)benzene (1.61 g, $5 \mathrm{mmol}$ ) and aqueous $\mathrm{NaOH}(3 \mathrm{M}, 7.5 \mathrm{~mL})$ was added. The reaction mixture was stirred vigorously at room temperature for $1 \mathrm{~h}$. Precipitated solid was filtered off, washed with water $(3 \times 10 \mathrm{~mL})$ and $\mathrm{CHCl}_{3}(5$ $\mathrm{mL})$. After drying in air, the product was obtained as a white powder $(1.10 \mathrm{~g}, 99 \%$ yield).<smiles>Cc1ccccc1I=O</smiles>

2-Methyliodosylbenzene. The title compound was prepared from 2-methyl(diacetoxyiodo)benzene in $5.95 \mathrm{mmol}$ scale, following the same procedure as for iodosylbenzene. The product was obtained as a white solid (1.17 g, 84\% yield).<smiles>Cc1cccc(C)c1I=O</smiles>

2,6-Dimethyliodosylbenzene. The title compound was prepared from 2,6dimethyl(diacetoxyiodo)benzene in $5.7 \mathrm{mmol}$ scale, following the same procedure as for iodosylbenzene. The product was obtained as a white solid (1.27 g, 90\% yield).

\footnotetext{
${ }^{16}$ McCammant, M. S.; Thompson, S.; Brooks, A. F.; Krska, S. W.; Scott, P. J. H.; Sanford, M. S. Org. Lett. 2017, 19, 3939-3942.

${ }^{17}$ Merritt, E. A.; Carneiro, V. M. T.; Silva, L. F.; Olofsson, B. J. Org. Chem. 2010, 75, 7416-7419.

${ }^{18}$ Saltzman, H.; Sharefkin J. G. Org. Synth. 1963, 43, 60.
} 


$$
\overbrace{\mathrm{OMe}}^{\mathrm{N}}
$$

2-Methoxyiodosylbenzene. The title compound was prepared from 2-methoxy(diacetoxyiodo)benzene in $3 \mathrm{mmol}$ scale, following the same procedure as for iodosylbenzene. The product was obtained as a yellowish solid (415 mg, 55\% yield).<smiles>Cc1cc(C)c(I=O)c(C)c1</smiles>

2,4,6-Trimethyliodosylbenzene. The title compound was prepared from 1-[hydroxy(tosyloxy)iodo]2,4,6-trimethylbenzene in $68.2 \mathrm{mmol}$ scale, following the same procedure as for iodosylbenzene with the reaction time extended to $16 \mathrm{~h}$. The product was obtained as a yellowish solid (15.8 g, $88 \%$ yield).

\subsubsection{Synthesis of Trimethylsilylalkynes}

Starting materials for synthesis of 2-\{3-[2-(trimethylsilyl)ethynyl]phenyl $\}-2,3$-dihydro- $1 \mathrm{H}$ isoindole-1,3-dione and 4-\{2-[2-(Trimethylsilyl)ethynyl]benzenesulfonyl\}morpholine were prepared according to following procedures.

\section{Scheme S6.}<smiles>Nc1cccc(Br)c1</smiles><smiles>O=C1c2ccccc2C(=O)N1c1cccc(Br)c1</smiles>

$N$-(3-bromophenyl)phthalimide. ${ }^{19}$ Phthalic anhydride $(1.5 \mathrm{~g}, 10 \mathrm{mmol})$ and 3-bromoaniline $(1.09 \mathrm{~mL}$, $10 \mathrm{mmol})$ were added to $\mathrm{AcOH}(60 \mathrm{~mL})$ and refluxed overnight. After cooling to room temperature, water $(50 \mathrm{~mL})$ was added and the resulting suspension was stirred at room temperature for 15 minutes. Obtained solid was filtered off, washed with water $(2 \times 20 \mathrm{~mL})$, and dried under high vacuum, providing the product as a white solid $\left(2.79 \mathrm{~g}, 92 \%\right.$ yield). ${ }^{1} \mathrm{H} \mathrm{NMR}\left(400 \mathrm{MHz}, \mathrm{CDCl}_{3}\right) \delta 7.96(\mathrm{dd}, J=5.5,3.1$ $\mathrm{Hz}, 2 \mathrm{H}), 7.80(\mathrm{dd}, J=5.5,3.0 \mathrm{~Hz}, 2 \mathrm{H}), 7.65-7.61(\mathrm{~m}, 2 \mathrm{H}), 7.37-7.34(\mathrm{~m}, 2 \mathrm{H})$. The spectral data are in accordance with literature. ${ }^{20}$

\section{Scheme S7.}

\footnotetext{
${ }^{19}$ The procedure is a modified version of the procedure given in: Yuan, Y.-C.; Kamaraj, R.; Bruneau, C.; Labasque, T.; Roisnel, T.; GramageDoria, R. Org. Lett. 2017, 19, 6404-6407.

${ }^{20}$ Shrestha, R.; Mukherjee, P.; Tan, Y.; Litman, Z. C.; Hartwig, J. F. J. Am. Chem. Soc. 2013, 135, 8480-8483.
} 


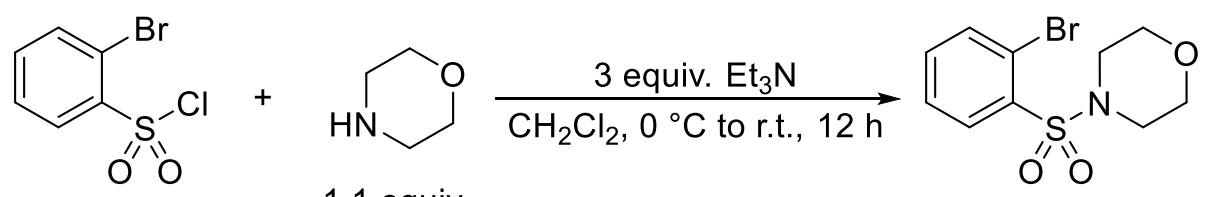

1.1 equiv.

4-(2-Bromobenzenesulfonyl)morpholine. ${ }^{21}$ A round-bottom flask was charged with 2bromobenzenesulfonyl chloride $(1.28 \mathrm{~g}, 5.0 \mathrm{mmol})$. Next, $\mathrm{CH}_{2} \mathrm{Cl}_{2}(25 \mathrm{~mL})$ and $\mathrm{Et}_{3} \mathrm{~N}$ (anhydrous, 2.08 $\mathrm{mL}, 15 \mathrm{mmol})$ were added. The reaction mixture was cooled down to $0{ }^{\circ} \mathrm{C}$ and morpholine $(484 \mu \mathrm{L}, 5.5$ mmol) was added dropwise. After the addition was completed, the cooling bath was removed and reaction mixture was stirred at room temperature for $12 \mathrm{~h}$. The volatiles were removed under reduced pressure, and $\mathrm{CH}_{2} \mathrm{Cl}_{2}(25 \mathrm{~mL})$ and water $(25 \mathrm{~mL})$ were added to the residue. The organic phase was separated and the aqueous phase was further extracted with $\mathrm{CH}_{2} \mathrm{Cl}_{2}(2 \times 25 \mathrm{~mL})$. The combined organic phases were dried over $\mathrm{MgSO}_{4}$, filtered, and evaporated under reduced pressure. The product was purified by column chromatography (silica, petroleum ether:ethyl acetate/4:1) and was obtained as a colorless solid (1.45 g, 95\%). ${ }^{1} \mathrm{H}$ NMR $\left(400 \mathrm{MHz}, \mathrm{CDCl}_{3}\right) \delta 8.10-8.07(\mathrm{~m}, 1 \mathrm{H}), 7.79-7.75(\mathrm{~m}, 1 \mathrm{H})$, $7.49-7.38(\mathrm{~m}, 2 \mathrm{H}), 3.75-3.71(\mathrm{~m}, 4 \mathrm{H}), 3.32-3.28(\mathrm{~m}, 4 \mathrm{H})$. The spectral data are in accordance with literature. $^{22}$

Trimethylsilylalkynes was prepared according to the following procedure. ${ }^{10}$

\section{Scheme S8.}<smiles>[X]c1cccc([X])c1</smiles>

$\mathrm{X}=\mathrm{Br}, \mathrm{I}$

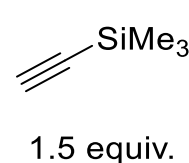

1.5 equiv.

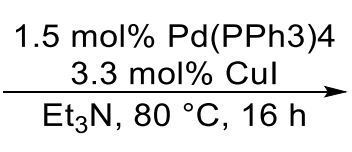

$\underset{\mathrm{Et}_{3} \mathrm{~N}, 80^{\circ} \mathrm{C}, 16 \mathrm{~h}}{\mathrm{~mol}}$

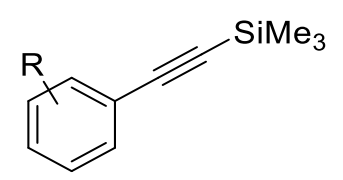

\section{General Procedure 1}

In a nitrogen-atmosphere glovebox, an oven-dried pressure ampoule (or an oven-dried $30 \mathrm{~mL}$ vial, depending on the reaction scale) was charged with aryl halide (1.0 equiv.), $\mathrm{Pd}\left(\mathrm{PPh}_{3}\right)_{4}(1.5 \mathrm{~mol} \%)$, and $\mathrm{CuI}(3.3 \mathrm{~mol} \%)$. Next, $\mathrm{Et}_{3} \mathrm{~N}$ (degassed, $2.5 \mathrm{~mL} / \mathrm{mmol}$ of aryl halide) and trimethylsilylacetylene (1.5 equiv.) were added. The ampule was capped, removed for the glovebox, and stirred at $80^{\circ} \mathrm{C}$ for $16 \mathrm{~h}$. After cooling to room temperature, the reaction mixture was transferred to round-bottom flask with $\mathrm{CH}_{2} \mathrm{Cl}_{2}$. The volatiles were removed under reduced pressure and $\mathrm{Et}_{2} \mathrm{O}(10 \mathrm{~mL} / \mathrm{mmol})$ was added to the residue, resulting in the formation of triethylammonium halide precipitate, which was removed by filtration though short pad of silica using $\mathrm{Et}_{2} \mathrm{O}$. The filtrate was concentrated under reduced pressure and the product was purified by column chromatography.

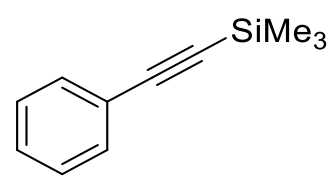

Trimethyl(2-phenylethynyl)silane. The title compound was prepared according to the General Procedure 1 in $15 \mathrm{mmol}$ scale from iodobenzene $(1.68 \mathrm{~mL}, 15 \mathrm{mmol})$, trimethylsilylacetylene $(3.28 \mathrm{~mL}$, $22.5 \mathrm{mmol}), \mathrm{Pd}\left(\mathrm{PPh}_{3}\right)_{4}(265 \mathrm{mg}, 0.225 \mathrm{mmol}), \mathrm{CuI}(94.3 \mathrm{mg}, 0.495 \mathrm{mmol})$, and $\mathrm{Et}_{3} \mathrm{~N}(37.5 \mathrm{~mL})$. The product was purified by column chromatography (silica, petroleum ether) and it was obtained as a

\footnotetext{
${ }^{21}$ The procedure is a modified version of the procedure given in: Bheeter, C. B.; Jin, R.; Bera, J. K.; Dixneuf, P. H.; Doucet, H. Adv. Synth. Catal. 2014, 356, 119-124.

${ }^{22}$ Yotphan, S.; Sumunnee, L.; Beukeaw, D.; Buathongjan, C.; Reutrakul, V. Org. Biomol. Chem. 2016, 14, $590-597$.
} 
colorless liquid (2.56 g, 98\% yield). ${ }^{1} \mathrm{H}$ NMR (400 MHz, $\left.\mathrm{CDCl}_{3}\right) \delta 7.50-7.43(\mathrm{~m}, 2 \mathrm{H}), 7.34-7.26$ (m, $3 \mathrm{H}), 0.26(\mathrm{~s}, 9 \mathrm{H})$. The spectral data are in accordance with literature. ${ }^{23}$<smiles>CCC#Cc1c(C)cccc1C</smiles>

[2-(2,6-Dimethylphenyl)ethynyl]trimethylsilane. The title compound was prepared according to the General Procedure 1 in $10 \mathrm{mmol}$ scale from 2,6-dimethyliodobenzene $(1.47 \mathrm{~mL}, 10 \mathrm{mmol})$, trimethylsilylacetylene ( $2.19 \mathrm{~mL}, 15 \mathrm{mmol}), \mathrm{Pd}\left(\mathrm{PPh}_{3}\right)_{4}(177 \mathrm{mg}, 0.15 \mathrm{mmol}), \mathrm{CuI}(62.8 \mathrm{mg}, 0.33 \mathrm{mmol})$, and $\mathrm{Et}_{3} \mathrm{~N}(25 \mathrm{~mL})$. The product was purified by column chromatography (silica, petroleum ether:ethyl acetate/100:0 to 94:6) and it was obtained as a colorless liquid (1.93 g, 96\% yield). ${ }^{1} \mathrm{H}$ NMR (400 MHz, $\left.\mathrm{CDCl}_{3}\right) \delta 7.10(\mathrm{dd}, J=8.4,6.6 \mathrm{~Hz}, 1 \mathrm{H}), 7.02(\mathrm{~d}, J=7.7 \mathrm{~Hz}, 2 \mathrm{H}), 2.43(\mathrm{~s}, 6 \mathrm{H}), 0.27(\mathrm{~s}, 9 \mathrm{H})$. The spectral data are in accordance with literature. ${ }^{24}$<smiles>CC(C)(C)C#Cc1ccc(C(C)(C)C)cc1</smiles>

[2-(4-tert-Butylphenyl)ethynyl]trimethylsilane. The title compound was prepared according to the General Procedure 1 in $4.75 \mathrm{mmol}$ scale from 4-tert-butyliodobenzene $(842 \mu \mathrm{L}, 4.75 \mathrm{mmol})$, trimethylsilylacetylene (1.05 mL, $7.13 \mathrm{mmol}), \mathrm{Pd}\left(\mathrm{PPh}_{3}\right)_{4}(84 \mathrm{mg}, 0.072 \mathrm{mmol}), \mathrm{CuI}(29.9 \mathrm{mg}, 0.157$ $\mathrm{mmol})$, and $\mathrm{Et}_{3} \mathrm{~N}(12 \mathrm{~mL})$. The product was purified by column chromatography (silica, petroleum ether) and it was obtained as a colorless solid (1.08 g, 99\% yield). ${ }^{1} \mathrm{H}$ NMR (400 MHz, $\left.\mathrm{CDCl}_{3}\right) \delta 7.41-7.38$ $(\mathrm{m}, 2 \mathrm{H}), 7.33-7.29(\mathrm{~m}, 2 \mathrm{H}), 1.30(\mathrm{~s}, 9 \mathrm{H}), 0.24(\mathrm{~s}, 9 \mathrm{H})$. The spectral data are in accordance with literature. $^{25}$<smiles>CC#Cc1cccc(-c2ccccc2)c1</smiles>

(2-\{[1,1'-Biphenyl]-3-yl\}ethynyl)trimethylsilane. The title compound was prepared according to the General Procedure 1 in $8 \mathrm{mmol}$ scale from 3-bromobiphenyl $(1.36 \mathrm{~mL}, 8 \mathrm{mmol})$, trimethylsilylacetylene (1.76 mL, $12 \mathrm{mmol}), \mathrm{Pd}\left(\mathrm{PPh}_{3}\right)_{4}(142 \mathrm{mg}, 0.12 \mathrm{mmol}), \mathrm{CuI}(50.3 \mathrm{mg}, 0.264 \mathrm{mmol})$, and $\mathrm{Et}_{3} \mathrm{~N}(20 \mathrm{~mL})$. The product was purified by column chromatography (silica, petroleum ether:ethyl acetate/20:0 to 19:1) and it was obtained as a yellowish liquid $\left(1.80 \mathrm{~g}, 90 \%\right.$ yield). ${ }^{1} \mathrm{H}$ NMR $\left(400 \mathrm{MHz}, \mathrm{CDCl}_{3}\right) \delta 7.73-7.71$ (m, 1H), $7.61-7.57(\mathrm{~m}, 2 \mathrm{H}), 7.55$ (ddd, $J=7.7,1.9,1.3 \mathrm{~Hz}, 1 \mathrm{H}), 7.47-7.42(\mathrm{~m}, 3 \mathrm{H}), 7.40-7.34$ (m, $2 \mathrm{H}), 0.28(\mathrm{~s}, 9 \mathrm{H})$.<smiles>CC#Cc1ccc2ccccc2c1</smiles>

Trimethyl[2-(naphthalen-2-yl)ethynyl]silane. The title compound was prepared according to the General Procedure 1 in $10 \mathrm{mmol}$ scale from 2-bromonaphtalene (2.07 g, $10 \mathrm{mmol})$,

\footnotetext{
${ }^{23}$ Truong, T.; Daugulis, O. Org. Lett. 2011, 13, 4172-4175.

${ }^{24}$ Panda, J.; Virkler, P. R.; Detty, M. R. J. Org. Chem. 2003, 68, 1804-1809.

${ }^{25}$ Xu, C.; Du, W.; Zeng, Y.; Dai, B.; Guo, H. Org. Lett. 2014, 16, 948-951.
} 
trimethylsilylacetylene (2.19 mL, $15 \mathrm{mmol}), \mathrm{Pd}\left(\mathrm{PPh}_{3}\right)_{4}(177 \mathrm{mg}, 0.15 \mathrm{mmol}), \mathrm{CuI}(62.8 \mathrm{mg}, 0.33 \mathrm{mmol})$, and $\mathrm{Et}_{3} \mathrm{~N}(25 \mathrm{~mL})$. The product was purified by column chromatography (silica, petroleum ether:ethyl acetate/100:0 to 94:6) and it was obtained as a yellowish solid (2.21 g, 98\% yield). ${ }^{1} \mathrm{H}$ NMR (400 MHz, $\left.\mathrm{CDCl}_{3}\right) \delta 8.00(\mathrm{~d}, J=0.4 \mathrm{~Hz}, 1 \mathrm{H}), 7.83-7.74(\mathrm{~m}, 3 \mathrm{H}), 7.54-7.45(\mathrm{~m}, 3 \mathrm{H}), 0.29(\mathrm{~s}, 9 \mathrm{H})$. The spectral data are in accordance with literature. ${ }^{26}$<smiles>CC#Cc1cc(F)cc(F)c1</smiles>

[2-(3,5-Difluorophenyl)ethynyl]trimethylsilane. The title compound was prepared according to the General Procedure 1 in $6 \mathrm{mmol}$ scale from 3,5-difluoroiodobenzene (719 $\mu \mathrm{L}, 6 \mathrm{mmol})$, trimethylsilylacetylene (1.32 mL, $9 \mathrm{mmol}), \mathrm{Pd}\left(\mathrm{PPh}_{3}\right)_{4}(106 \mathrm{mg}, 0.09 \mathrm{mmol}), \mathrm{CuI}(37.7 \mathrm{mg}, 0.198 \mathrm{mmol}$ ), and $\mathrm{Et}_{3} \mathrm{~N}(15 \mathrm{~mL})$. The product was purified by column chromatography (silica, petroleum ether:ethyl acetate/20:0 to 19:1) and it was obtained as a colorless liquid (1.24 g, 98\% yield). ${ }^{1} \mathrm{H}$ NMR (400 MHz, $\left.\mathrm{CDCl}_{3}\right) \delta 7.00-6.93(\mathrm{~m}, 2 \mathrm{H}), 6.78(\mathrm{tt}, J=9.0,2.4 \mathrm{~Hz}, 1 \mathrm{H}), 0.25(\mathrm{~s}, 9 \mathrm{H}) .{ }^{19} \mathrm{~F}$ NMR $\left(376 \mathrm{MHz}, \mathrm{CDCl}_{3}\right)$ $\delta-109.8--109.9(\mathrm{~m})$. The spectral data are in accordance with literature. ${ }^{27}$<smiles>CC#Cc1ccccc1C(F)(F)F</smiles>

Trimethyl(\{2-[2-(trifluoromethyl)phenyl]ethynyl\})silane. The title compound was prepared according to the General Procedure 1 in $10 \mathrm{mmol}$ scale from 2-(trifluoromethyl)iodobenzene $(1.44 \mathrm{~mL}$, $10 \mathrm{mmol})$, trimethylsilylacetylene (2.19 mL, $15 \mathrm{mmol}), \mathrm{Pd}\left(\mathrm{PPh}_{3}\right)_{4}(177 \mathrm{mg}, 0.15 \mathrm{mmol}), \mathrm{CuI}(62.8 \mathrm{mg}$, $0.55 \mathrm{mmol}$ ), and $\mathrm{Et}_{3} \mathrm{~N}(25 \mathrm{~mL})$. The product was purified by column chromatography (silica, petroleum ether:ethyl acetate/100:0 to 99:1) and it was obtained as a yellowish liquid (2.02 g, 83\% yield). ${ }^{1} \mathrm{H}$ NMR $\left(400 \mathrm{MHz}, \mathrm{CDCl}_{3}\right) \delta 7.63(\mathrm{dd}, J=7.8,0.6 \mathrm{~Hz}, 1 \mathrm{H}), 7.60(\mathrm{dd}, J=7.7,0.6 \mathrm{~Hz}, 1 \mathrm{H}), 7.50-7.44(\mathrm{~m}, 1 \mathrm{H})$, $7.40(\mathrm{ddd}, J=8.3,1.3,0.7 \mathrm{~Hz}, 1 \mathrm{H}), 0.26(\mathrm{~s}, 5 \mathrm{H}) .{ }^{19} \mathrm{~F} \mathrm{NMR}\left(376 \mathrm{MHz}, \mathrm{CDCl}_{3}\right) \delta-62.5(\mathrm{~s})$.<smiles>CC#Cc1ccc(Cl)c(Cl)c1</smiles>

[2-(3,4-Dichlorophenyl)ethynyl]trimethylsilane. The title compound was prepared according to the General Procedure 1 in $6 \mathrm{mmol}$ scale from 3,4-dichlorobromobenzene (1.37 g, $6 \mathrm{mmol}$ ), trimethylsilylacetylene (1.32 mL, $9 \mathrm{mmol}), \mathrm{Pd}\left(\mathrm{PPh}_{3}\right)_{4}(106 \mathrm{mg}, 0.09 \mathrm{mmol}), \mathrm{CuI}(37.7 \mathrm{mg}, 0.196 \mathrm{mmol})$, and $\mathrm{Et}_{3} \mathrm{~N}(15 \mathrm{~mL})$. The product was purified by column chromatography (silica, petroleum ether:ethyl acetate/20:0 to 19:1) and it was obtained as a colorless liquid (1.39 g, 95\% yield). ${ }^{1} \mathrm{H}$ NMR (400 MHz, $\left.\mathrm{CDCl}_{3}\right) \delta 7.55(\mathrm{~d}, J=1.9 \mathrm{~Hz}, 1 \mathrm{H}), 7.37(\mathrm{~d}, J=8.3 \mathrm{~Hz}, 1 \mathrm{H}), 7.27(\mathrm{dd}, J=8.2,1.8 \mathrm{~Hz}, 2 \mathrm{H}), 0.25(\mathrm{~s}, 9 \mathrm{H})$. The spectral data are in accordance with literature. ${ }^{28}$

\footnotetext{
${ }^{26}$ Hatial, I.; Mukherjee, R.; Senapati, K.; Basak, A. Tetrahedron Lett. 2015, 56, 4275-4279.

${ }^{27}$ Lei, Y.; Hu, T.; Wu, X.; Wu, Y.; Xiang, H.; Sun, H.; You, Q.; Zhang, X. Tetrahedron Lett. 2016, 57, $1100-1103$.

${ }^{28}$ Onda, K.; Shiraki, R.; Yonetoku, Y.; Momose, K.; Katayama, N.; Orita, M.; Yamaguchi, T.; Ohta, M.; Tsukamoto, S.-i. Bioorg. Med. Chem. 2008, 16, 8627-8634
} 
<smiles>CC#Cc1ccc(C#N)cc1</smiles>

4-[2-(Trimethylsilyl)ethynyl]benzonitrile. The title compound was prepared according to the General Procedure 1 in $4.75 \mathrm{mmol}$ scale from 4-iodobenzonitrile $(1.09 \mathrm{~g}, 4.75 \mathrm{mmol})$, trimethylsilylacetylene (1.05 mL, $7.13 \mathrm{mmol}), \mathrm{Pd}\left(\mathrm{PPh}_{3}\right)_{4}(84 \mathrm{mg}, 0.072 \mathrm{mmol}), \mathrm{CuI}(29.9 \mathrm{mg}, 0.157 \mathrm{mmol})$, and $\mathrm{Et}_{3} \mathrm{~N}(12 \mathrm{~mL})$. The product was purified by column chromatography (silica, petroleum ether:ethyl acetate/19:1 to 18:2) and it was obtained as a yellow solid (908 $\mathrm{mg}, 96 \%$ yield). ${ }^{1} \mathrm{H}$ NMR (400 $\left.\mathrm{MHz}, \mathrm{CDCl}_{3}\right) \delta 7.61-7.57$ $(\mathrm{m}, 2 \mathrm{H}), 7.55-7.51(\mathrm{~m}, 2 \mathrm{H}), 0.26(\mathrm{~s}, 9 \mathrm{H})$. The spectral data are in accordance with literature. ${ }^{29}$<smiles>CC#Cc1ccc(C(C)=O)cc1</smiles>

1-\{4-[2-(Trimethylsilyl)ethynyl]phenyl\}ethan-1-one. The title compound was prepared according to the General Procedure 1 in $10 \mathrm{mmol}$ scale from 4-iodoacetophenone (2.51 g, $10 \mathrm{mmol})$, trimethylsilylacetylene ( $2.19 \mathrm{~mL}, 15 \mathrm{mmol}), \mathrm{Pd}\left(\mathrm{PPh}_{3}\right)_{4}(177 \mathrm{mg}, 0.15 \mathrm{mmol}), \mathrm{CuI}(62.8 \mathrm{mg}, 0.55 \mathrm{mmol})$, and $\mathrm{Et}_{3} \mathrm{~N}(25 \mathrm{~mL})$. The product was purified by column chromatography (silica, petroleum ether:ethyl acetate/19:1) and it was obtained as a yellow solid (2.04 g, 94\% yield). ${ }^{1} \mathrm{H}$ NMR (400 MHz, $\left.\mathrm{CDCl}_{3}\right) \delta$ $7.91-7.86(\mathrm{~m}, 2 \mathrm{H}), 7.56-7.52(\mathrm{~m}, 2 \mathrm{H}), 2.59(\mathrm{~s}, 3 \mathrm{H}), 0.26(\mathrm{~s}, 9 \mathrm{H})$. The spectral data are in accordance with literature. ${ }^{24}$

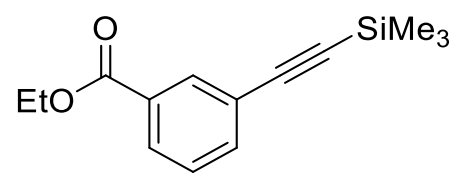

Ethyl 3-[2-(trimethylsilyl)ethynyl]benzoate. The title compound was prepared according to the General Procedure 1 in $8 \mathrm{mmol}$ scale from ethyl 3-iodobenzoate $(137 \mu \mathrm{L}, 8 \mathrm{mmol})$, trimethylsilylacetylene $(1.76 \mathrm{~mL}, 12 \mathrm{mmol}), \mathrm{Pd}\left(\mathrm{PPh}_{3}\right)_{4}(142 \mathrm{mg}, 0.12 \mathrm{mmol}), \mathrm{CuI}(50.3 \mathrm{mg}, 0.264$ $\mathrm{mmol}$ ), and $\mathrm{Et}_{3} \mathrm{~N}(20 \mathrm{~mL})$. The product was purified by column chromatography (silica, petroleum ether:ethyl acetate/19:1) and it was obtained as a yellowish liquid (1.94 g, 98\% yield). ${ }^{1} \mathrm{H}$ NMR (400 $\left.\mathrm{MHz}, \mathrm{CDCl}_{3}\right) \delta 8.13(\mathrm{td}, J=1.7,0.6 \mathrm{~Hz}, 1 \mathrm{H}), 7.98(\mathrm{ddd}, J=7.9,1.7,1.3 \mathrm{~Hz}, 1 \mathrm{H}), 7.65-7.61(\mathrm{~m}, 1 \mathrm{H})$, $7.38(\mathrm{td}, J=7.8,0.5 \mathrm{~Hz}, 1 \mathrm{H}), 4.38(\mathrm{q}, J=7.2 \mathrm{~Hz}, 2 \mathrm{H}), 1.40(\mathrm{t}, J=7.1 \mathrm{~Hz}, 3 \mathrm{H}), 0.26$ (s, 9H). The spectral data are in accordance with literature. ${ }^{30}$<smiles>COc1cccc(C#C[AsH2]C)c1</smiles>

[2-(3-Methoxyphenyl)ethynyl]trimethylsilane. The title compound was prepared according to the General Procedure 1 in $5 \mathrm{mmol}$ scale from 3-bromoanisole $(636 \mu \mathrm{L}, 5 \mathrm{mmol})$, trimethylsilylacetylene (1.1 mL, $7.5 \mathrm{mmol}), \mathrm{Pd}\left(\mathrm{PPh}_{3}\right)_{4}(88.4 \mathrm{mg}, 0.075 \mathrm{mmol}), \mathrm{CuI}(31.4 \mathrm{mg}, 0.165 \mathrm{mmol})$, and $\mathrm{Et}_{3} \mathrm{~N}(12.5$ $\mathrm{mL}$ ). The product was purified by column chromatography (silica, petroleum ether:ethyl acetate/19:1)

\footnotetext{
${ }^{29}$ Munoz, S. B.; Aloia, A. N.; Moore, A. K.; Papp, A.; Mathew, T.; Fustero, S.; Olah, G. A.; Surya Prakash, G. K. Org. Biomol. Chem. 2016, 14, 85-92.

${ }^{30}$ Iijima, T.; Endo, Y.; Tsuji, M.; Kawachi, E.; Kagechika, H.; Shudo, K. Chem. Pharm. Bull. 1999, 47, 398-404.
} 
and it was obtained as a yellowish liquid (1.01 g, 99\% yield). ${ }^{1} \mathrm{H}$ NMR (400 $\left.\mathrm{MHz}, \mathrm{CDCl}_{3}\right) \delta 7.23-7.17$ $(\mathrm{dd}, J=8.3,8.3 \mathrm{~Hz}, 1 \mathrm{H}), 7.06(\mathrm{dt}, J=7.6,1.2 \mathrm{~Hz}, 1 \mathrm{H}), 6.99$ (dd, $J=2.6,1.4 \mathrm{~Hz}, 1 \mathrm{H}), 6.87$ (ddd, $J=$ 8.3, 2.7, $1.0 \mathrm{~Hz}, 1 \mathrm{H}), 3.80(\mathrm{~s}, 3 \mathrm{H}), 0.25(\mathrm{~s}, 9 \mathrm{H})$. The spectral data are in accordance with literature. ${ }^{31}$

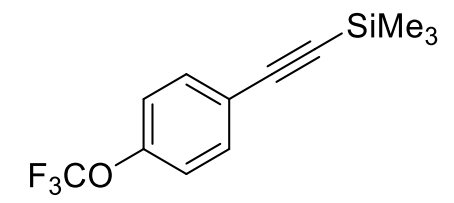

Trimethyl(\{2-[4-(trifluoromethoxy)phenyl]ethynyl\})silane. The title compound was prepared according to the General Procedure 1 in $25 \mathrm{mmol}$ scale from 4-(trifluoromethoxy)iodobenzene (3.91 $\mathrm{mL}, 25 \mathrm{mmol}$ ), trimethylsilylacetylene (5.5 mL, $37.5 \mathrm{mmol}), \mathrm{Pd}\left(\mathrm{PPh}_{3}\right)_{4}(442 \mathrm{mg}, 0.375 \mathrm{mmol}), \mathrm{CuI}$ (157 $\mathrm{mg}, 0.825 \mathrm{mmol})$, and $\mathrm{Et}_{3} \mathrm{~N}(62.5 \mathrm{~mL})$. The product was purified by column chromatography (silica, petroleum ether:ethyl acetate/100:0 to 99:1) and it was obtained as a colorless liquid (6.10 g, 95\% yield). ${ }^{1} \mathrm{H}$ NMR $\left(400 \mathrm{MHz}, \mathrm{CDCl}_{3}\right) \delta 7.51-7.46(\mathrm{~m}, 2 \mathrm{H}), 7.17-7.11(\mathrm{~m}, 2 \mathrm{H}), 0.25(\mathrm{~s}, 9 \mathrm{H}) .{ }^{19} \mathrm{~F}$ NMR (376 $\left.\mathrm{MHz}, \mathrm{CDCl}_{3}\right) \delta-57.8(\mathrm{~s})$. The spectral data are in accordance with literature. ${ }^{28}$

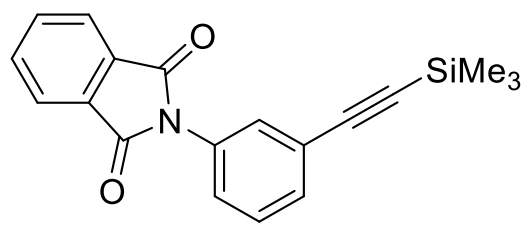

2-\{3-[2-(Trimethylsilyl)ethynyl]phenyl\}-2,3-dihydro-1H-isoindole-1,3-dione. The title compound was prepared according to the General Procedure 1 in 9.22 mmol scale from $\mathrm{N}-2$ bromophenylphthalimide ( $2.79 \mathrm{~g}, 9.22 \mathrm{mmol})$, trimethylsilylacetylene $(2.03 \mathrm{~mL}, 13.8 \mathrm{mmol}), \mathrm{Pd}\left(\mathrm{PPh}_{3}\right)_{4}$ (163 mg, $0.138 \mathrm{mmol}), \mathrm{CuI}(57.9 \mathrm{mg}, 0.304 \mathrm{mmol}), \mathrm{Et}_{3} \mathrm{~N}(23 \mathrm{~mL})$, and $\mathrm{CH}_{2} \mathrm{Cl}_{2}{ }^{32}(23 \mathrm{~mL})$. The product was purified by column chromatography (silica, petroleum ether:ethyl acetate/9:1 to 8:2) and it was obtained as a colorless solid (2.33 g, 79\% yield). ${ }^{1} \mathrm{H}$ NMR $\left(400 \mathrm{MHz}, \mathrm{CDCl}_{3}\right) \delta 7.99-7.93(\mathrm{~m}, 2 \mathrm{H})$, $7.83-7.78(\mathrm{~m}, 2 \mathrm{H}), 7.59-7.56(\mathrm{~m}, 1 \mathrm{H}), 7.51-7.47(\mathrm{~m}, 1 \mathrm{H}), 7.46-7.39(\mathrm{~m}, 2 \mathrm{H}), 0.25(\mathrm{~s}, 9 \mathrm{H})$.<smiles>CSC#Cc1ccccc1S(=O)(=O)N1CCOCC1</smiles>

4-\{2-[2-(Trimethylsilyl)ethynyl]benzenesulfonyl\}morpholine. The title compound was prepared according to the General Procedure 1 in $4.75 \mathrm{mmol}$ scale from 4-(2-bromobenzenesulfonyl)morpholine (1.45 g, $4.75 \mathrm{mmol})$, trimethylsilylacetylene (1.05 mL, $7.13 \mathrm{mmol}), \mathrm{Pd}\left(\mathrm{PPh}_{3}\right)_{4}(84 \mathrm{mg}, 0.072 \mathrm{mmol})$, $\mathrm{CuI}(29.9 \mathrm{mg}, 0.157 \mathrm{mmol})$, and $\mathrm{Et}_{3} \mathrm{~N}(12 \mathrm{~mL})$. The product was purified by column chromatography (silica, petroleum ether) and it was obtained as a yellow solid (1.34 g, 87\% yield). ${ }^{1} \mathrm{H}$ NMR (400 MHz, $\left.\mathrm{CDCl}_{3}\right) \delta 7.94-7.90(\mathrm{~m}, 1 \mathrm{H}), 7.69-7.65(\mathrm{~m}, 1 \mathrm{H}), 7.51(\mathrm{td}, J=7.6,1.4 \mathrm{~Hz}, 1 \mathrm{H}), 7.47-7.41(\mathrm{~m}, 1 \mathrm{H})$, $3.74-3.69(\mathrm{~m}, 4 \mathrm{H}), 3.26-3.22(\mathrm{~m}, 4 \mathrm{H}), 0.26(\mathrm{~s}, 9 \mathrm{H})$.

\subsubsection{Synthesis of Alkynyliodonium Salts}

Iodonium salts $\mathbf{2 f}$ and $\mathbf{2 g}$ were prepared according to following procedures:

\footnotetext{
${ }^{31}$ Ueda, H.; Yamaguchi, M.; Kameya, H.; Sugimoto, K.; Tokuyama, H. Org. Lett. 2014, 16, 4948-4951.

${ }^{32} \mathrm{CH}_{2} \mathrm{Cl}_{2}$ was used as a co-solvent due to the insolubility of substrate in $\mathrm{Et}_{3} \mathrm{~N}$, the reaction was performed at $60{ }^{\circ} \mathrm{C}$ in a pressure ampoule.
} 


\section{Scheme S9.}

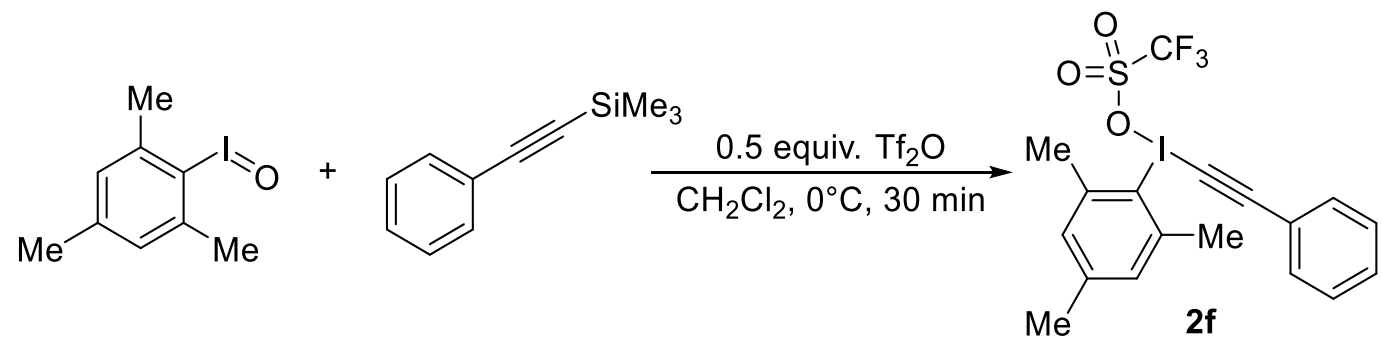

(2-phenylethynyl)(2,4,6-trimethylphenyl)iodonium trifluoromethanesulfonate (2f). ${ }^{33}$ To a solution of iodosylmesitylene (944 mg, $3.6 \mathrm{mmol})$ in $\mathrm{CH}_{2} \mathrm{Cl}_{2}(3.6 \mathrm{~mL}), \mathrm{Tf}_{2} \mathrm{O}(309 \mu \mathrm{L}, 1.8 \mathrm{mmol})$ was slowly added dropwise via syringe at $0{ }^{\circ} \mathrm{C}$. The resulting mixture was stirred at $0{ }^{\circ} \mathrm{C}$, until it become a clear yellow solution (c.a. $10 \mathrm{~min}$.). Next, trimethyl(2-phenylethynyl)silane $(628 \mathrm{mg}, 3.6 \mathrm{mmol})$ solution in $\mathrm{CH}_{2} \mathrm{Cl}_{2}(3.6 \mathrm{~mL})$ was added via syringe and the reaction mixture was stirred at $0{ }^{\circ} \mathrm{C}$ for $30 \mathrm{~min}$. The volatiles were removed under reduced pressure and $\mathrm{Et}_{2} \mathrm{O}(10 \mathrm{~mL})$ was added to the residue. Precipitated solid was washed with $\mathrm{Et}_{2} \mathrm{O}(2 \times 5 \mathrm{~mL})$ and dried under high vacuum, providing the product as colorless crystals (730 mg, $41 \%$ yield). ${ }^{1} \mathrm{H}$ NMR $\left(400 \mathrm{MHz}, \mathrm{CDCl}_{3}\right) \delta 7.49-7.43(\mathrm{~m}, 3 \mathrm{H}), 7.41-7.34(\mathrm{~m}, 2 \mathrm{H})$, $7.15(\mathrm{~s}, 2 \mathrm{H}), 2.78(\mathrm{~s}, 6 \mathrm{H}), 2.38(\mathrm{~s}, 3 \mathrm{H}) .{ }^{19} \mathrm{~F}$ NMR $\left(376 \mathrm{MHz}, \mathrm{CDCl}_{3}\right) \delta-78.2(\mathrm{~s})$. The spectral data are in accordance with literature. ${ }^{33}$

Scheme S10.

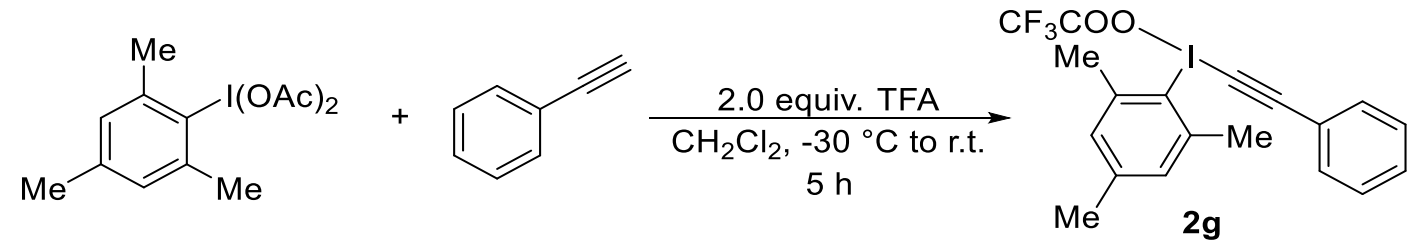

(2-phenylethynyl)(2,4,6-trimethylphenyl)iodonium trifluoroacetate (2g). ${ }^{34}$ To a solution of 2,4,6trimethyl-(diacetoxyiodo)benzene ( $839 \mathrm{mg}, 2.27 \mathrm{mmol}$ ) in $\mathrm{CH}_{2} \mathrm{Cl}_{2}(13.6 \mathrm{~mL}$ ), trifluoroacetic acid (355 $\mu \mathrm{L}, 4.54 \mathrm{mmol}$ ) was slowly added dropwise via syringe at $-30{ }^{\circ} \mathrm{C}$. The reaction mixture was stirred at $-30{ }^{\circ} \mathrm{C}$ for 30 minutes and for further $1 \mathrm{~h}$ at room temperature. Next, phenylacetylene $(249 \mu \mathrm{L}, 2.27$ mmol) was added via syringe and the rection mixture was stirred at room temperature in darkness for $3.5 \mathrm{~h}$. The volatiles were removed under reduced pressure, and $\mathrm{Et}_{2} \mathrm{O}(10 \mathrm{~mL})$ and petroleum ether $(10$ $\mathrm{mL}$ ) were added to the residue, which initiated the crystallization of product. After being placed in a freezer $\left(-28^{\circ} \mathrm{C}\right)$ overnight, the product was filtered off and dried under high vacuum, providing colorless crystals (434 mg, $42 \%$ yield). ${ }^{1} \mathrm{H}$ NMR $\left(400 \mathrm{MHz}, \mathrm{CDCl}_{3}\right) \delta 7.43-7.37(\mathrm{~m}, 3 \mathrm{H}), 7.36-7.30(\mathrm{~m}, 2 \mathrm{H})$, $7.10(\mathrm{~s}, 2 \mathrm{H}), 2.79(\mathrm{~s}, 6 \mathrm{H}), 2.35$ (s, 3H). ${ }^{19} \mathrm{~F}$ NMR $\left(376 \mathrm{MHz}, \mathrm{CDCl}_{3}\right) \delta-75.3$ (s). The spectral data are in accordance with literature. ${ }^{34}$

Iodonium salts $\mathbf{2 a - e}$ and $\mathbf{2 h}-\mathbf{v}$ were prepared according to following procedure: ${ }^{35}$

\footnotetext{
${ }^{33}$ Bachi, M. D.; Bar-Ner, N.; Crittell, C. M.; Stang, P. J.; Williamson, B. L. J. Org. Chem. 1991, 56, 3912-3915.

${ }^{34}$ Dixon, L. I.; Carroll, M. A.; Gregson, T. J.; Ellames, G. J.; Harrington, R. W.; Clegg, W. Eur. J. Org. Chem. 2013, 2334-2345.

${ }^{35}$ Slightly modified version of the procedure given in Stang, P. J.; Kitamura, T. Org. Synth. 1992, 70, 215.
} 
Scheme S11.

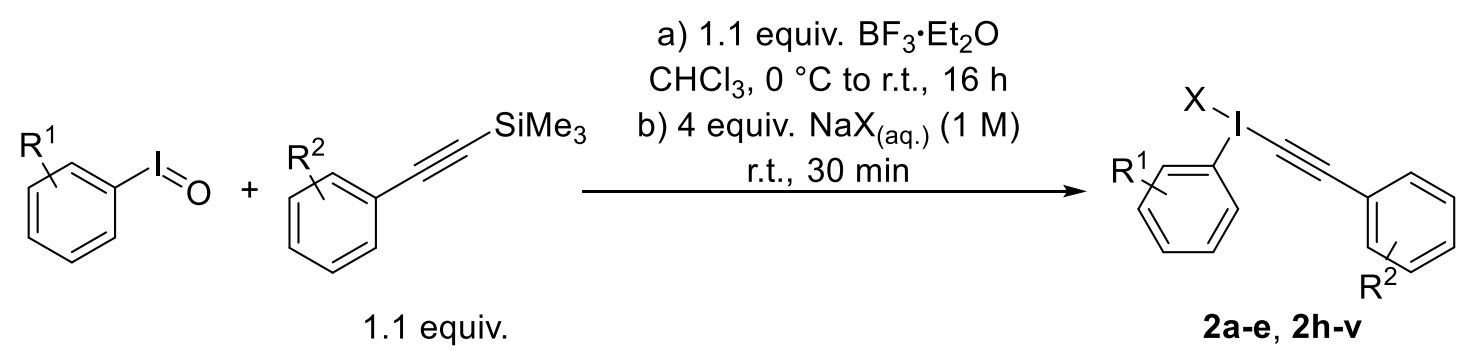

\section{General Procedure 2}

A round bottom flask was charged with iodosylarene (1 equiv.) and solid (trimethylsilylethynyl)arene (1.1 equiv.). The flask was capped with a rubber septum and evacuated/back-filled with nitrogen. Next, $\mathrm{CHCl}_{3}(2 \mathrm{~mL} / \mathrm{mmol}$ substrate) was added via syringe, followed by liquid (trimethylsilylethynyl)arene. The resulting mixture was cooled down to $0{ }^{\circ} \mathrm{C}$ and $\mathrm{BF}_{3} \cdot \mathrm{Et}_{2} \mathrm{O}$ (1.1 equiv.) was added dropwise via syringe. After the addition was complete, the cooling bath was removed, and the reaction mixture was stirred at room temperature for $16 \mathrm{~h}$. Aqueous $\mathrm{NaX}(1 \mathrm{M}, 4$ equiv.) was added via syringe and the resulting mixture was stirred vigorously at room temperature for 30 minutes. Next, the biphasic mixture was transferred to separatory funnel and the organic phase was separated. The aqueous phase was extracted with $\mathrm{CH}_{2} \mathrm{Cl}_{2}(2 \times 1 \mathrm{~mL} / \mathrm{mmol}$ substrate $)$ and the combined organic phases were dried over anhydrous $\mathrm{MgSO}_{4}$, filtered, and concentrated under reduced pressure. $\mathrm{Et}_{2} \mathrm{O}(2 \mathrm{~mL} / \mathrm{mmol}$ substrate $)$ was added to the residue, inducing the precipitation of iodonium salt. ${ }^{36}$ The flask was kept at $4{ }^{\circ} \mathrm{C}$ or $-30{ }^{\circ} \mathrm{C}$ for $1 \mathrm{~h}$, the solid was filtered off, washed several times with $\mathrm{Et}_{2} \mathrm{O}(0.5 \mathrm{~mL} / \mathrm{mmol}$ of substrate for each washing), and dried under high vacuum.<smiles>Cc1ccc(S(=O)(=O)OI(C#Cc2ccccc2)c2c(C)cc(C)cc2C)cc1</smiles>

(2-Phenylethynyl)(2,4,6-trimethylphenyl)iodonium $p$-toluenosulfonate (2a). The title compound was prepared according to the General Procedure 2 in $15 \mathrm{mmol}$ scale from iodosylmesitylene $(3.93 \mathrm{~g}$, $15 \mathrm{mmol})$, trimethyl(2-phenylethynyl)silane $(2.88 \mathrm{~g}, 16.5 \mathrm{mmol})$, and boron trifluoride etherate (2.06 $\mathrm{mL}, 16.5 \mathrm{mmol})$ in $30 \mathrm{~mL}$ of $\mathrm{CHCl}_{3}$, using $60 \mathrm{~mL}$ of $1 \mathrm{M}$ aqueous sodium $p$-toluenosulfonate $(11.7 \mathrm{~g}$, $60 \mathrm{mmol}$ ) in the second step. The product was precipitated from $30 \mathrm{~mL}$ of $\mathrm{Et}_{2} \mathrm{O}$ and after drying under high vacuum it was obtained as a yellowish solid (4.15 g, 53\% yield). ${ }^{1} \mathrm{H}$ NMR (400 $\left.\mathrm{MHz}, \mathrm{CDCl}_{3}\right) \delta$ $7.53-7.49(\mathrm{~m}, 2 \mathrm{H}), 7.43-7.38(\mathrm{~m}, 3 \mathrm{H}), 7.36-7.31(\mathrm{~m}, 2 \mathrm{H}), 7.08-7.04(\mathrm{~m}, 2 \mathrm{H}), 7.03(\mathrm{~s}, 2 \mathrm{H}), 2.73$ (s, 6H), $2.33(\mathrm{~s}, J=1.3 \mathrm{~Hz}, 3 \mathrm{H}), 2.32(\mathrm{~s}, 3 \mathrm{H})$.

${ }^{36}$ Sometimes for the better quality of the precipitate, the crude residue was first dissolved in a minimal amount of $\mathrm{CH}_{2} \mathrm{Cl}_{2}(1-2 \mathrm{~mL})$, and then $\mathrm{Et}_{2} \mathrm{O}$ was added in one portion. 


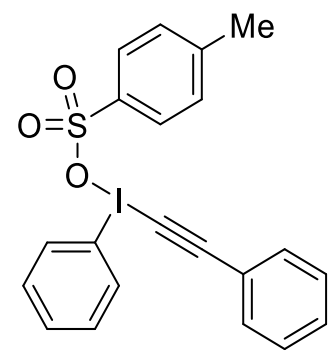

2b

Phenyl(2-phenylethynyl)iodonium p-toluenosulfonate (2b). The title compound was prepared according to the General Procedure 2 in $4 \mathrm{mmol}$ scale from iodosylbenzene ( $880 \mathrm{mg}, 4 \mathrm{mmol}$ ), trimethyl(2-phenylethynyl)silane ( $767 \mathrm{mg}, 4.4 \mathrm{mmol})$, and boron trifluoride etherate $(549 \mu \mathrm{L}, 4.4 \mathrm{mmol})$ in $8 \mathrm{~mL}$ of $\mathrm{CHCl}_{3}$, using $16 \mathrm{~mL}$ of $1 \mathrm{M}$ aqueous sodium $p$-toluenosulfonate $(3.27 \mathrm{~g}, 16 \mathrm{mmol})$ in the second step. The product was precipitated from $8 \mathrm{~mL}$ of $\mathrm{Et}_{2} \mathrm{O}$ and after drying under high vacuum it was obtained as an ivory solid (627 mg, 33\% yield). ${ }^{1} \mathrm{H}$ NMR (400 MHz, $\left.\mathrm{CDCl}_{3}\right) \delta 8.18-8.14(\mathrm{~m}, 2 \mathrm{H}), 7.69$ $-7.64(\mathrm{~m}, 2 \mathrm{H}), 7.61-7.56(\mathrm{~m}, 1 \mathrm{H}), 7.50-7.42(\mathrm{~m}, 5 \mathrm{H}), 7.40-7.34(\mathrm{~m}, 2 \mathrm{H}), 7.12(\mathrm{~d}, J=8.0 \mathrm{~Hz}, 2 \mathrm{H})$, $2.33(\mathrm{~s}, 3 \mathrm{H})$. The spectral data are in accordance with literature. ${ }^{37}$

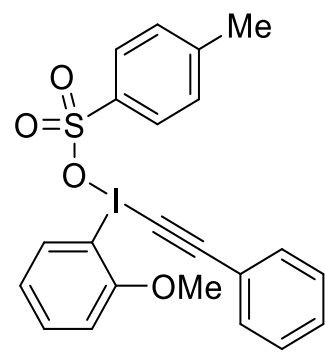

2c

(2-Methoxyphenyl)(2-phenylethynyl)iodanium $p$-toluenosulfonate (2c). The title compound was prepared according to the General Procedure 2 in $2 \mathrm{mmol}$ scale from 2-methoxy-iodosylbenzene (500 $\mathrm{mg}, 2 \mathrm{mmol}$ ), trimethyl(2-phenylethynyl)silane ( $384 \mathrm{mg}, 2.2 \mathrm{mmol}$ ), and boron trifluoride etherate (274 $\mu \mathrm{L}, 2.2 \mathrm{mmol})$ in $4 \mathrm{~mL}$ of $\mathrm{CHCl}_{3}$, using $8 \mathrm{~mL}$ of $1 \mathrm{M}$ aqueous sodium $p$-toluenosulfonate $(1.64 \mathrm{~g}, 8$ $\mathrm{mmol})$ in the second step. The product was precipitated from $4 \mathrm{~mL}$ of $\mathrm{Et}_{2} \mathrm{O}$ and after drying under high vacuum it was obtained as an orange solid ( $380 \mathrm{mg}, 38 \%$ yield). ${ }^{1} \mathrm{H}$ NMR $\left(400 \mathrm{MHz}, \mathrm{CDCl}_{3}\right) \delta 1 \mathrm{H} \mathrm{NMR}$ $\left(400 \mathrm{MHz}, \mathrm{CDCl}_{3}\right) \delta 7.51(\mathrm{~d}, J=8.2 \mathrm{~Hz}, 2 \mathrm{H}), 7.23(\mathrm{~d}, J=8.0 \mathrm{~Hz}, 1 \mathrm{H}), 7.06(\mathrm{~d}, J=7.9 \mathrm{~Hz}, 2 \mathrm{H}), 7.03$ (s, 2H), $7.01-6.98(\mathrm{~m}, 1 \mathrm{H}), 6.95$ (ddd, $J=8.4,2.6,0.9 \mathrm{~Hz}, 1 \mathrm{H}), 6.91$ (dd, $J=2.4,1.4 \mathrm{~Hz}, 1 \mathrm{H}), 3.78$ (s, $3 \mathrm{H}), 2.73(\mathrm{~s}, 6 \mathrm{H}), 2.33(\mathrm{~s}, 3 \mathrm{H}), 2.32(\mathrm{~s}, 3 \mathrm{H})$. The spectral data are in accordance with literature. ${ }^{38}$<smiles>Cc1ccc(S(=O)(=O)OI(C#Cc2ccccc2)c2ccccc2C)cc1</smiles>

2d

(2-Methylphenyl)(2-phenylethynyl)iodonium $p$-toluenosulfonate (2d). The title compound was prepared according to the General Procedure 2 in $5 \mathrm{mmol}$ scale from 2-methyl-iodosylbenzene $(1.17 \mathrm{~g}$,

\footnotetext{
${ }^{37}$ Bouma, M. J.; Olofsson, B. Chem. Eur. J. 2012, 18, 14242-14245.

${ }^{38}$ Hamnett, D. J.; Moran, W. J. Org. Biomol. Chem. 2014, 12, 4156-4162.
} 
$5 \mathrm{mmol})$, trimethyl(2-phenylethynyl)silane ( $959 \mathrm{mg}, 5.5 \mathrm{mmol})$, and boron trifluoride etherate $(686 \mu \mathrm{L}$, $5.5 \mathrm{mmol}$ ) in $10 \mathrm{~mL}$ of $\mathrm{CHCl}_{3}$, using $20 \mathrm{~mL}$ of $1 \mathrm{M}$ aqueous sodium $p$-toluenosulfonate $(4.09 \mathrm{~g}, 20$ $\mathrm{mmol}$ ) in the second step. The product was precipitated from $10 \mathrm{~mL}$ of $\mathrm{Et}_{2} \mathrm{O}$ and after drying under high vacuum it was obtained as an off-white solid ( $478 \mathrm{mg}, 20 \%$ yield). ${ }^{1} \mathrm{H} \mathrm{NMR}\left(400 \mathrm{MHz}, \mathrm{CDCl}_{3}\right) \delta 8.16$ $(\mathrm{dd}, J=8.2,1.1 \mathrm{~Hz}, 1 \mathrm{H}), 7.56-7.53(\mathrm{~m}, 2 \mathrm{H}), 7.50(\mathrm{dd}, J=7.4,1.0 \mathrm{~Hz}, 1 \mathrm{H}), 7.45(\mathrm{dd}, J=7.6,1.4 \mathrm{~Hz}$, 1H), $7.44-7.38(\mathrm{~m}, 3 \mathrm{H}), 7.36-7.31(\mathrm{~m}, 2 \mathrm{H}), 7.23-7.18(\mathrm{~m}, 1 \mathrm{H}), 7.10-7.04(\mathrm{~m}, 2 \mathrm{H}), 2.76(\mathrm{~s}, 3 \mathrm{H})$, $2.32(\mathrm{~s}, 3 \mathrm{H})$.<smiles>Cc1ccc(S(=O)(=O)OI(C#Cc2ccccc2)c2c(C)cccc2C)cc1</smiles>

2e

(2,6-Dimethylphenyl)(2-phenylethynyl)iodonium $p$-toluenosulfonate (2e). The title compound was prepared according to the General Procedure 2 in $5 \mathrm{mmol}$ scale from 2,6-dmethyl-iodosylbenzene (1.24 g, $5 \mathrm{mmol}$ ), trimethyl(2-phenylethynyl)silane $(959 \mathrm{mg}, 5.5 \mathrm{mmol})$, and boron trifluoride etherate (686 $\mu \mathrm{L}, 5.5 \mathrm{mmol})$ in $10 \mathrm{~mL}$ of $\mathrm{CHCl}_{3}$, using $20 \mathrm{~mL}$ of $1 \mathrm{M}$ aqueous sodium $p$-toluenosulfonate $(4.09 \mathrm{~g}, 20$ $\mathrm{mmol}$ ) in the second step. The product was precipitated from $10 \mathrm{~mL}$ of $\mathrm{Et}_{2} \mathrm{O}$ and after drying under high vacuum it was obtained as an off-white solid (1.60 g, 63\% yield). ${ }^{1} \mathrm{H} \mathrm{NMR}\left(400 \mathrm{MHz}, \mathrm{CDCl}_{3}\right) \delta 7.51-$ $7.46(\mathrm{~m}, 2 \mathrm{H}), 7.44-7.30(\mathrm{~m}, 6 \mathrm{H}), 7.24(\mathrm{~d}, J=7.4 \mathrm{~Hz}, 2 \mathrm{H}), 7.08-7.02(\mathrm{~m}, 2 \mathrm{H}), 2.78(\mathrm{~s}, 3 \mathrm{H}), 2.32$ (s, $3 \mathrm{H})$.

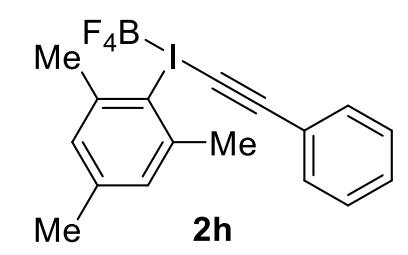

(2-Phenylethynyl)(2,4,6-trimethylphenyl)iodonium tetrafluoroborate (2h). The title compound was prepared according to the General Procedure 2 in $1.3 \mathrm{mmol}$ scale from iodosylmesitylene ( $341 \mathrm{mg}, 1.3$ $\mathrm{mmol}$ ), trimethyl(2-phenylethynyl)silane $(249 \mathrm{mg}, 1.43 \mathrm{mmol})$, and boron trifluoride etherate $(178 \mu \mathrm{L}$, $1.43 \mathrm{mmol}$ ) in $3 \mathrm{~mL}$ of $\mathrm{CHCl}_{3}$, using $6 \mathrm{~mL}$ of $0.87 \mathrm{M}$ aqueous sodium tetrafluoroborate $(583 \mathrm{mg}, 5.2$ $\mathrm{mmol}$ ) in the second step. The product was precipitated from $3 \mathrm{~mL}$ of $\mathrm{Et}_{2} \mathrm{O}$ and after drying under high vacuum it was obtained as a brownish solid $\left(169 \mathrm{mg}, 30 \%\right.$ yield). ${ }^{1} \mathrm{H} \mathrm{NMR}\left(400 \mathrm{MHz}, \mathrm{CDCl}_{3}\right) \delta 7.53-$ $7.44(\mathrm{~m}, 3 \mathrm{H}), 7.41-7.35$ (m, 2H), 7.15 (s, 2H), $2.78(\mathrm{~s}, 6 \mathrm{H}), 2.38(\mathrm{~s}, 3 \mathrm{H}) .{ }^{19} \mathrm{~F}$ NMR $\left(376 \mathrm{MHz}, \mathrm{CDCl}_{3}\right)$ $\delta-146.7(\mathrm{~s})$.<smiles>Cc1ccc(S(=O)(=O)OI(C#Cc2c(C)cccc2C)c2c(C)cc(C)cc2C)cc1</smiles> 
[2-(2,6-dimethylphenyl)ethynyl](2,4,6-trimethylphenyl)iodonium $p$-toluenosulfonate (2i). The title compound was prepared according to the General Procedure 2 in $3.1 \mathrm{mmol}$ scale from iodosylmesitylene (810 mg, $3.1 \mathrm{mmol})$, [2-(2,6-dimethylphenyl)ethynyl]trimethylsilane $(688 \mathrm{mg}, 3.41 \mathrm{mmol})$, and boron trifluoride etherate $(424 \mu \mathrm{L}, 3.41 \mathrm{mmol})$ in $6.2 \mathrm{~mL}$ of $\mathrm{CHCl}_{3}$, using $12.4 \mathrm{~mL}$ of $1 \mathrm{M}$ aqueous sodium $p$ toluenosulfonate $(2.4 \mathrm{~g}, 12.4 \mathrm{mmol})$. The product was precipitated from $6 \mathrm{~mL}$ of $\mathrm{Et}_{2} \mathrm{O}$ and after drying under high vacuum it was obtained as a yellowish solid (905 mg, 54\% yield). ${ }^{1} \mathrm{H}$ NMR (400 $\mathrm{MHz}$, $\left.\mathrm{CDCl}_{3}\right) \delta 7.55-7.50(\mathrm{~m}, 2 \mathrm{H}), 7.19-7.13(\mathrm{~m}, 1 \mathrm{H}), 7.06(\mathrm{~d}, J=8.0 \mathrm{~Hz}, 2 \mathrm{H}), 7.03(\mathrm{~s}, 2 \mathrm{H}), 7.02(\mathrm{~d}, J=$ $8.2 \mathrm{~Hz}, 2 \mathrm{H}), 2.75$ (s, 6H), 2.33 (s, 6H), $2.30(\mathrm{~s}, 6 \mathrm{H})$.

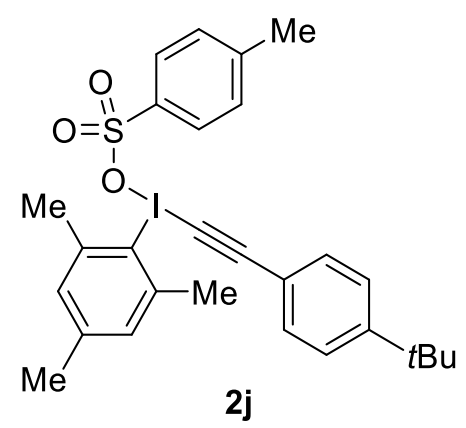

[2-(4-tert-Butylphenyl)ethynyl](2,4,6-trimethylphenyl)iodonium $p$-toluenosulfonate (2j). The title compound was prepared according to the General Procedure 2 in 2 mmol scale from iodosylmesitylene (524 mg, $2 \mathrm{mmol}$ ), [2-(4-tert-butylphenyl)ethynyl]trimethylsilane $(507 \mathrm{mg}, 2.2 \mathrm{mmol}$ ), and boron trifluoride etherate $(274 \mu \mathrm{L}, 2.2 \mathrm{mmol})$ in $4 \mathrm{~mL}$ of $\mathrm{CHCl}_{3}$, using $8 \mathrm{~mL}$ of $1 \mathrm{M}$ aqueous sodium $p$ toluenosulfonate $(1.64 \mathrm{~g}, 8 \mathrm{mmol})$ in the second step. The product was precipitated from $4 \mathrm{~mL}$ of $\mathrm{Et}_{2} \mathrm{O}$ and after drying under high vacuum it was obtained as a white solid (556 mg, $48 \%$ yield). ${ }^{1} \mathrm{H}$ NMR (400 $\left.\mathrm{MHz}, \mathrm{CDCl}_{3}\right) \delta 7.53-7.49(\mathrm{~m}, 2 \mathrm{H}), 7.35(\mathrm{~s}, 4 \mathrm{H}), 7.08-7.04(\mathrm{~m}, 2 \mathrm{H}), 7.02(\mathrm{~s}, 2 \mathrm{H}), 2.73(\mathrm{~s}, 6 \mathrm{H}), 2.33$ $(\mathrm{s}, 6 \mathrm{H}), 1.28(\mathrm{~s}, 9 \mathrm{H})$.<smiles>Cc1ccc(S(=O)(=O)OI(C#Cc2cccc(-c3ccccc3)c2)c2c(C)cc(C)cc2C)cc1</smiles>

(2-\{[1,1'-Biphenyl]-3-yl\}ethynyl)(2,4,6-trimethylphenyl)iodonium $p$-toluenosulfonate (2k). The title compound was prepared according to the General Procedure 2 in 4 mmol scale from iodosylmesitylene (1.05 g, $4 \mathrm{mmol}),\left(2-\left\{\left[1,1^{\prime}\right.\right.\right.$-biphenyl]-3-yl $\}$ ethynyl)trimethylsilane $(1.10 \mathrm{~g}, 4.4$ $\mathrm{mmol}$ ), and boron trifluoride etherate $(549 \mu \mathrm{L}, 4.4 \mathrm{mmol})$ in $8 \mathrm{~mL}$ of $\mathrm{CHCl}_{3}$, using $16 \mathrm{~mL}$ of $1 \mathrm{M}$ aqueous sodium $p$-toluenosulfonate $(3.11 \mathrm{~g}, 16 \mathrm{mmol})$ in the second step. The product was precipitated from $8 \mathrm{~mL}$ of $\mathrm{Et}_{2} \mathrm{O}$ and after drying under high vacuum it was obtained as a brownish solid $(1.20 \mathrm{~g}, 51 \%$ yield). ${ }^{1} \mathrm{H}$ NMR $\left(400 \mathrm{MHz}, \mathrm{CDCl}_{3}\right) \delta 7.63-7.59(\mathrm{~m}, 2 \mathrm{H}), 7.54-7.49(\mathrm{~m}, 4 \mathrm{H}), 7.46-7.35(\mathrm{~m}, 5 \mathrm{H})$, $7.04(\mathrm{~d}, J=8.8 \mathrm{~Hz}, 2 \mathrm{H}), 7.03(\mathrm{~s}, 2 \mathrm{H}), 2.74(\mathrm{~s}, 6 \mathrm{H}), 2.33$ (s, 3H), 2.31 (s, 3H). 
<smiles>Cc1ccc(S(=O)(=O)OI(C#Cc2ccc3ccccc3c2)c2c(C)cc(C)cc2C)cc1</smiles>

[2-(Naphthalen-2-yl)ethynyl](2,4,6-trimethylphenyl)iodonium $p$-toluenosulfonate (2l). The title compound was prepared according to the General Procedure 2 in 4 mmol scale from iodosylmesitylene (1.05 g, $4 \mathrm{mmol}$ ), trimethyl[2-(naphthalen-2-yl)ethynyl]silane ( $987 \mathrm{mg}, 4.4 \mathrm{mmol})$, and boron trifluoride etherate $(549 \mu \mathrm{L}, 4.4 \mathrm{mmol})$ in $8 \mathrm{~mL}$ of $\mathrm{CHCl}_{3}$, using $16 \mathrm{~mL}$ of $1 \mathrm{M}$ aqueous sodium $p$-toluenosulfonate $(3.11 \mathrm{~g}, 16 \mathrm{mmol})$ in the second step. The product was precipitated from $8 \mathrm{~mL}$ of $\mathrm{Et}_{2} \mathrm{O}$ and after drying under high vacuum it was obtained as a brown solid (764 mg, $34 \%$ yield). ${ }^{1} \mathrm{H}$ NMR (400 MHz, $\mathrm{CDCl}_{3}$ ) $\delta 7.96(\mathrm{~d}, J=0.9 \mathrm{~Hz}, 1 \mathrm{H}), 7.85-7.75(\mathrm{~m}, 3 \mathrm{H}), 7.58-7.50(\mathrm{~m}, 4 \mathrm{H}), 7.40(\mathrm{dd}, J=8.5,1.6 \mathrm{~Hz}, 1 \mathrm{H}), 7.06$ (dd, $J=10.1,0.5 \mathrm{~Hz}, 2 \mathrm{H}), 7.05$ (s, 2H), 2.76 (s, 6H), 2.34 (s, 3H), 2.32 (s, 3H).<smiles>Cc1ccc(S(=O)(=O)OI(C#Cc2cc(F)cc(F)c2)c2c(C)cc(C)cc2C)cc1</smiles>

[2-(3,5-Difluorophenyl)ethynyl](2,4,6-trimethylphenyl)iodonium $p$-toluenosulfonate (2m). The title compound was prepared according to the General Procedure 2 in 4 mmol scale from iodosylmesitylene (1.05 g, $4 \mathrm{mmol})$, [2-(3,5-difluorophenyl)ethynyl]trimethylsilane (925 mg, 4.4 mmol), and boron trifluoride etherate $(549 \mu \mathrm{L}, 4.4 \mathrm{mmol})$ in $8 \mathrm{~mL}$ of $\mathrm{CHCl}_{3}$, using $16 \mathrm{~mL}$ of $1 \mathrm{M}$ aqueous sodium $p$-toluenosulfonate $(3.11 \mathrm{~g}, 16 \mathrm{mmol})$ in the second step. The product was precipitated from $8 \mathrm{~mL}$ of $\mathrm{Et}_{2} \mathrm{O}$ and after drying under high vacuum it was obtained as an off-white solid $(1.49 \mathrm{~g}$, $67 \%$ yield). ${ }^{1} \mathrm{H}$ NMR $\left(400 \mathrm{MHz}, \mathrm{CDCl}_{3}\right) \delta 7.52-7.47(\mathrm{~m}, 2 \mathrm{H}), 7.04(\mathrm{~d}, J=8.0 \mathrm{~Hz}, 2 \mathrm{H}), 7.02(\mathrm{~s}, 2 \mathrm{H})$, $6.91-6.81(\mathrm{~m}, 3 \mathrm{H}), 2.70(\mathrm{~s}, 6 \mathrm{H}), 2.33(\mathrm{~s}, 3 \mathrm{H}), 2.32(\mathrm{~s}, 3 \mathrm{H}) .{ }^{19} \mathrm{~F} \mathrm{NMR}\left(376 \mathrm{MHz}, \mathrm{CDCl}_{3}\right) \delta-108.1--$ $108.2(\mathrm{~m})$.<smiles>Cc1ccc(S(=O)(=O)OI(C#Cc2ccccc2C(F)(F)F)c2c(C)cc(C)cc2C)cc1</smiles>

\{2-[2-(Trifluoromethyl)phenyl]ethynyl\}(2,4,6-trimethylphenyl)iodonium $p$-toluenosulfonate (2n). The title compound was prepared according to the General Procedure 2 in $2 \mathrm{mmol}$ scale from iodosylmesitylene (524 mg, $2 \mathrm{mmol}$ ), trimethyl(\{2-[2-(trifluoromethyl)phenyl]ethynyl $\})$ silane (533 mg, 
$2.2 \mathrm{mmol}$ ), and boron trifluoride etherate $(274 \mu \mathrm{L}, 2.2 \mathrm{mmol})$ in $4 \mathrm{~mL}$ of $\mathrm{CHCl}_{3}$, using $8 \mathrm{~mL}$ of $1 \mathrm{M}$ aqueous sodium $p$-toluenosulfonate $(1.64 \mathrm{~g}, 8 \mathrm{mmol})$ in the second step. The product was precipitated from $4 \mathrm{~mL}$ of $\mathrm{Et}_{2} \mathrm{O}$ and after drying under high vacuum it was obtained as a yellowish solid $(589 \mathrm{mg}$, $50 \%$ yield). ${ }^{1} \mathrm{H}$ NMR $\left(400 \mathrm{MHz}, \mathrm{CDCl}_{3}\right) \delta 7.66-7.63(\mathrm{~m}, 1 \mathrm{H}), 7.59-7.50(\mathrm{~m}, 3 \mathrm{H}), 7.48(\mathrm{~d}, J=8.2$ $\mathrm{Hz}, 2 \mathrm{H}), 7.05(\mathrm{~d}, J=8.0 \mathrm{~Hz}, 2 \mathrm{H}), 7.03(\mathrm{~s}, 2 \mathrm{H}), 2.72(\mathrm{~s}, 6 \mathrm{H}), 2.33(\mathrm{~s}, 3 \mathrm{H}), 2.32(\mathrm{~s}, 3 \mathrm{H}) .{ }^{19} \mathrm{~F} \mathrm{NMR}(376$ $\left.\mathrm{MHz}, \mathrm{CDCl}_{3}\right) \delta-62.2(\mathrm{~s})$.<smiles>Cc1ccc(S(=O)(=O)OI(C#Cc2ccc(Cl)c(Cl)c2)c2c(C)cc(C)cc2C)cc1</smiles>

[2-(3,4-Dichlorophenyl)ethynyl](2,4,6-trimethylphenyl)iodonium $p$-toluenosulfonate (20). The title compound was prepared according to the General Procedure 2 in 2 mmol scale from iodosylmesitylene (524 mg, $2 \mathrm{mmol}$ ), [2-(3,4-dichlorophenyl)ethynyl]trimethylsilane (535 mg, $2.2 \mathrm{mmol})$, and boron trifluoride etherate $(274 \mu \mathrm{L}, 2.2 \mathrm{mmol})$ in $4 \mathrm{~mL}$ of $\mathrm{CHCl}_{3}$, using $8 \mathrm{~mL}$ of $1 \mathrm{M}$ aqueous sodium $p$ toluenosulfonate $(1.64 \mathrm{~g}, 8 \mathrm{mmol})$ in the second step. The product was precipitated from $4 \mathrm{~mL}$ of $\mathrm{Et}_{2} \mathrm{O}$ and after drying under high vacuum it was obtained as an off-white solid (605 mg, 52\% yield). ${ }^{1} \mathrm{H}$ NMR $\left(400 \mathrm{MHz}, \mathrm{CDCl}_{3}\right) \delta 7.50(\mathrm{~d}, J=8.1 \mathrm{~Hz}, 2 \mathrm{H}), 7.47(\mathrm{~d}, J=1.9 \mathrm{~Hz}, 1 \mathrm{H}), 7.41(\mathrm{~d}, J=8.3 \mathrm{~Hz}, 1 \mathrm{H}), 7.23$ (dd, $J=8.3,1.9 \mathrm{~Hz}, 1 \mathrm{H}), 7.06(\mathrm{~d}, J=8.5 \mathrm{~Hz}, 2 \mathrm{H}), 7.04(\mathrm{~s}, 2 \mathrm{H}), 2.71(\mathrm{~s}, 6 \mathrm{H}), 2.34(\mathrm{~s}, 3 \mathrm{H}), 2.33(\mathrm{~s}, 3 \mathrm{H})$.<smiles>Cc1ccc(S(=O)(=O)OI(C#Cc2ccc(C#N)cc2)c2c(C)cc(C)cc2C)cc1</smiles>

[2-(4-Cyanophenyl)ethynyl](2,4,6-trimethylphenyl)iodonium $p$-toluenosulfonate (2p). The title compound was prepared according to the General Procedure 2 in $2 \mathrm{mmol}$ scale from iodosylmesitylene (524 mg, $2 \mathrm{mmol}$ ), 4-[2-(trimethylsilyl)ethynyl]benzonitrile (439 mg, $2.2 \mathrm{mmol}$ ), and boron trifluoride etherate $(274 \mu \mathrm{L}, 2.2 \mathrm{mmol})$ in $4 \mathrm{~mL}$ of $\mathrm{CHCl}_{3}$, using $8 \mathrm{~mL}$ of $1 \mathrm{M}$ aqueous sodium $p$-toluenosulfonate $(1.64 \mathrm{~g}, 8 \mathrm{mmol})$ in the second step. The product was precipitated from $4 \mathrm{~mL}$ of $\mathrm{Et}_{2} \mathrm{O}$ and after drying under high vacuum it was obtained as an off-white solid (414 mg, 38\% yield). ${ }^{1} \mathrm{H}$ NMR (400 MHz, $\left.\mathrm{CDCl}_{3}\right) \delta 7.62-7.58(\mathrm{~m}, 2 \mathrm{H}), 7.50-7.45(\mathrm{~m}, 4 \mathrm{H}), 7.04(\mathrm{~d}, J=8.1 \mathrm{~Hz}, 2 \mathrm{H}), 7.03(\mathrm{~s}, 2 \mathrm{H}), 2.70(\mathrm{~s}, 6 \mathrm{H})$, $2.33(\mathrm{~s}, 3 \mathrm{H}), 2.32(\mathrm{~s}, 3 \mathrm{H})$. 
<smiles>CC(=O)c1ccc(C#CI(OS(=O)(=O)c2ccc(C)cc2)c2c(C)cc(C)cc2C)cc1</smiles>

[2-(4-Acetylphenyl)ethynyl](2,4,6-trimethylphenyl)iodonium $p$-toluenosulfonate (2q). The title compound was prepared according to the General Procedure 2 in $4 \mathrm{mmol}$ scale from iodosylmesitylene (1.05 mg, $4 \mathrm{mmol}), 1-\{4$-[2-(trimethylsilyl)ethynyl]phenyl \}ethan-1-one (952 mg, $4.4 \mathrm{mmol})$, and boron trifluoride etherate $(549 \mu \mathrm{L}, 4.4 \mathrm{mmol})$ in $8 \mathrm{~mL}$ of $\mathrm{CHCl}_{3}$, using $16 \mathrm{~mL}$ of $1 \mathrm{M}$ aqueous sodium $p$ toluenosulfonate $(3.27 \mathrm{~g}, 16 \mathrm{mmol})$ in the second step. The product was precipitated from $8 \mathrm{~mL}$ of $\mathrm{Et}_{2} \mathrm{O}$ and after drying under high vacuum it was obtained as an orange solid (921 mg, $41 \%$ yield). ${ }^{1} \mathrm{H}$ NMR $\left(400 \mathrm{MHz}, \mathrm{CDCl}_{3}\right) \delta 7.93-7.88(\mathrm{~m}, 2 \mathrm{H}), 7.53-7.46(\mathrm{~m}, 4 \mathrm{H}), 7.05(\mathrm{~d}, J=10.5 \mathrm{~Hz}, 2 \mathrm{H}), 7.04(\mathrm{~s}, 2 \mathrm{H})$, $2.73(\mathrm{~s}, 6 \mathrm{H}), 2.59(\mathrm{~s}, 3 \mathrm{H}), 2.34(\mathrm{~s}, 3 \mathrm{H}), 2.33(\mathrm{~s}, 3 \mathrm{H})$.<smiles>CCOC(=O)c1cccc(C#CI(OS(=O)(=O)c2ccc(C)cc2)c2c(C)cc(C)cc2C)c1</smiles>

\{2-[3-(Ethoxycarbonyl)phenyl]ethynyl\}(2,4,6-trimethylphenyl)iodonium $p$-toluenosulfonate (2r). The title compound was prepared according to the General Procedure 2 in $4 \mathrm{mmol}$ scale from iodosylmesitylene (1.05 g, $4 \mathrm{mmol})$, ethyl 3-[2-(trimethylsilyl)ethynyl]benzoate (1.08 g, $4.4 \mathrm{mmol})$, and boron trifluoride etherate $(549 \mu \mathrm{L}, 4.4 \mathrm{mmol})$ in $8 \mathrm{~mL}$ of $\mathrm{CHCl}_{3}$, using $16 \mathrm{~mL}$ of $1 \mathrm{M}$ aqueous sodium $p$-toluenosulfonate $(3.27 \mathrm{~g}, 16 \mathrm{mmol})$ in the second step. The product was precipitated from $8 \mathrm{~mL}$ of $\mathrm{Et}_{2} \mathrm{O}$ and after drying under high vacuum it was obtained as a yellowish solid $\left(1.27 \mathrm{~g}, 54 \%\right.$ yield). ${ }^{1} \mathrm{H}$ NMR (400 MHz, $\left.\mathrm{CDCl}_{3}\right) \delta 8.08-8.04(\mathrm{~m}, 2 \mathrm{H}), 7.58(\mathrm{dt}, J=7.7,1.4 \mathrm{~Hz}, 1 \mathrm{H}), 7.53-7.49(\mathrm{~m}, 2 \mathrm{H}), 7.45$ $-7.40(\mathrm{~m}, 1 \mathrm{H}), 7.06(\mathrm{dd}, J=8.4,0.5 \mathrm{~Hz}, 2 \mathrm{H}), 7.04(\mathrm{~s}, 2 \mathrm{H}), 4.38(\mathrm{q}, J=7.1 \mathrm{~Hz}, 2 \mathrm{H}), 2.73(\mathrm{~s}, 6 \mathrm{H}), 2.34$ (s, 3H), 2.33 (s, 3H), 1.39 (t, $J=7.1 \mathrm{~Hz}, 3 \mathrm{H})$.<smiles>COc1cccc(C#CI(OS(=O)(=O)c2ccc(C)cc2)c2c(C)cc(C)cc2C)c1</smiles>

[2-(3-Methoxyphenyl)ethynyl](2,4,6-trimethylphenyl)iodonium $p$-toluenosulfonate (2s). The title compound was prepared according to the General Procedure 2 in $11.1 \mathrm{mmol}$ scale from iodosylmesitylene $(2.91 \mathrm{~g}, 11.1 \mathrm{mmol})$, [2-(3-methoxyphenyl)ethynyl]trimethylsilane $(2.50 \mathrm{~g}, 12.2$ 
mmol), and boron trifluoride etherate $(1.52 \mathrm{~mL}, 12.2 \mathrm{mmol})$ in $22 \mathrm{~mL}$ of $\mathrm{CHCl}_{3}$, using $44 \mathrm{~mL}$ of $1 \mathrm{M}$ aqueous sodium $p$-toluenosulfonate $(8.62 \mathrm{~g}, 44.4 \mathrm{mmol})$ in the second step. The product was precipitated from $22 \mathrm{~mL}$ of $\mathrm{Et}_{2} \mathrm{O}$ and after drying under high vacuum it was obtained as a reddish solid $(1.85 \mathrm{~g}, 30 \%$ yield). ${ }^{1} \mathrm{H}$ NMR $\left(400 \mathrm{MHz}, \mathrm{CDCl}_{3}\right) \delta 7.53-7.48(\mathrm{~m}, 1 \mathrm{H}), 7.26-7.21(\mathrm{~m}, 1 \mathrm{H}), 7.05(\mathrm{~d}, J=8.0 \mathrm{~Hz}, 2 \mathrm{H})$, $7.03(\mathrm{~s}, 2 \mathrm{H}), 6.99(\mathrm{dt}, J=7.6,1.1 \mathrm{~Hz}, 1 \mathrm{H}), 6.95(\mathrm{ddd}, J=8.4,2.6,0.9 \mathrm{~Hz}, 1 \mathrm{H}), 6.91(\mathrm{dd}, J=2.5,1.4$ $\mathrm{Hz}, 1 \mathrm{H}), 3.78$ (s, 3H), 2.73 (s, 6H), 2.33 (s, 3H), 2.32 (s, 3H).

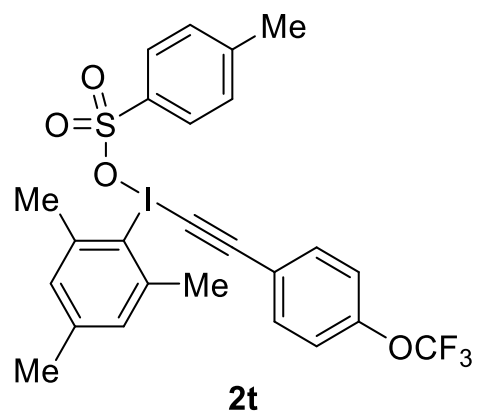

\{2-[4-(Trifluoromethoxy)phenyl]ethynyl\}(2,4,6-trimethylphenyl)iodonium $\quad p$-toluenosulfonate (2t). The title compound was prepared according to the General Procedure 2 in 24 mmol scale from iodosylmesitylene $(6.29 \mathrm{~g}, 24 \mathrm{mmol})$, trimethyl(\{2-[4-(trifluoromethoxy)phenyl]ethynyl $\})$ silane (6.82 $\mathrm{g}, 26.4 \mathrm{mmol})$, and boron trifluoride etherate $(3.29 \mathrm{~mL}, 26.4 \mathrm{mmol})$ in $48 \mathrm{~mL}$ of $\mathrm{CHCl}_{3}$, using $96 \mathrm{~mL}$ of $1 \mathrm{M}$ aqueous sodium $p$-toluenosulfonate $(18.6 \mathrm{~g}, 96 \mathrm{mmol})$ in the second step. The product was precipitated from $50 \mathrm{~mL}$ of $\mathrm{Et}_{2} \mathrm{O}$ and after drying under high vacuum it was obtained as an off-white solid (6.19 g, 43\% yield). ${ }^{1} \mathrm{H}$ NMR (400 MHz, $\left.\mathrm{CDCl}_{3}\right) \delta 7.52-7.47(\mathrm{~m}, 2 \mathrm{H}), 7.45-7.40(\mathrm{~m}, 2 \mathrm{H}), 7.18$ $-7.14(\mathrm{~m}, 2 \mathrm{H}), 7.06-7.02(\mathrm{~m}, 2 \mathrm{H}), 7.02(\mathrm{~s}, J=5.6 \mathrm{~Hz}, 2 \mathrm{H}), 2.71(\mathrm{~s}, 6 \mathrm{H}), 2.32$ (s, 3H), $2.32(\mathrm{~s}, 3 \mathrm{H})$. ${ }^{19} \mathrm{~F}$ NMR $\left(376 \mathrm{MHz}, \mathrm{CDCl}_{3}\right) \delta-57.8(\mathrm{~s})$.

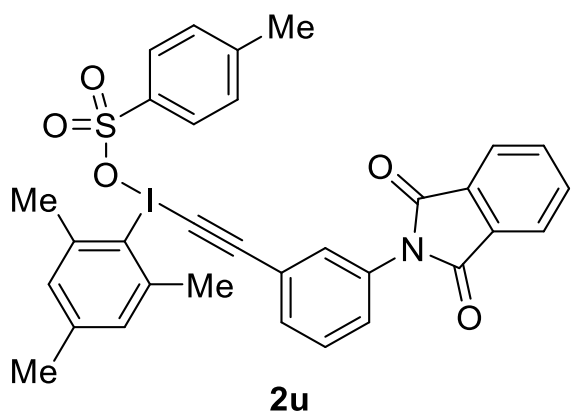

\{2-[3-(1,3-Dioxo-2,3-dihydro-1H-isoindol-2-yl)phenyl]ethynyl\}(2,4,6-trimethylphenyl)iodonium $p$-toluenosulfonate (2u). The title compound was prepared according to the General Procedure 2 in 6 mmol scale from iodosylmesitylene $(1.57 \mathrm{~g}, 6 \mathrm{mmol}), 2-\{3-[2$-(trimethylsilyl)ethynyl]phenyl $\}-2,3-$ dihydro-1H-isoindole-1,3-dione $(2.11 \mathrm{~g}, 6.6 \mathrm{mmol})$, and boron trifluoride etherate $(823 \mu \mathrm{L}, 6.6 \mathrm{mmol})$ in $12 \mathrm{~mL}$ of $\mathrm{CHCl}_{3}$, using $24 \mathrm{~mL}$ of $1 \mathrm{M}$ aqueous sodium $p$-toluenosulfonate (4.66 g, $24 \mathrm{mmol}$ ) in the second step. The product was precipitated from $12 \mathrm{~mL}$ of $\mathrm{Et}_{2} \mathrm{O}$ and after drying under high vacuum it was obtained as a brownish solid $\left(1.35 \mathrm{~g}, 34 \%\right.$ yield). ${ }^{1} \mathrm{H} \mathrm{NMR}\left(400 \mathrm{MHz}, \mathrm{CDCl}_{3}\right) \delta 7.99-7.93(\mathrm{~m}$, 2H), $7.84-7.78(\mathrm{~m}, 2 \mathrm{H}), 7.55-7.41(\mathrm{~m}, 6 \mathrm{H}), 7.06(\mathrm{~d}, J=7.9 \mathrm{~Hz}, 2 \mathrm{H}), 7.04(\mathrm{~s}, 2 \mathrm{H}), 2.73(\mathrm{~s}, 6 \mathrm{H}), 2.33$ (s, 3H), 2.33 (s, 3H). 
<smiles>Cc1ccc(S(=O)(=O)OI(C#Cc2ccccc2S(=O)(=O)N2CCOCC2)c2c(C)cc(C)cc2C)cc1</smiles>

\{2-[2-(Morpholine-4-sulfonyl)phenyl]ethynyl\}(2,4,6-trimethylphenyl)iodonium $\boldsymbol{p}$-toluenosulfonate (2v). The title compound was prepared according to the General Procedure 2 in $3.77 \mathrm{mmol}$ scale from iodosylmesitylene (988 mg, $3.77 \mathrm{mmol}$ ), 4-\{2-[2-(trimethylsilyl)ethynyl]benzenesulfonyl \}morpholine $(1.34 \mathrm{~g}, 4.15 \mathrm{mmol})$, and boron trifluoride etherate $(517 \mu \mathrm{L}, 4.15 \mathrm{mmol})$ in $7.5 \mathrm{~mL}$ of $\mathrm{CHCl}_{3}$, using 15 $\mathrm{mL}$ of $1 \mathrm{M}$ aqueous sodium $p$-toluenosulfonate $(3.08 \mathrm{~g}, 15.1 \mathrm{mmol})$ in the second step. The product was precipitated from $12 \mathrm{~mL}$ of $\mathrm{Et}_{2} \mathrm{O}$ and after drying under high vacuum it was obtained as an orange solid (1.37 g, 54\% yield). ${ }^{1} \mathrm{H}$ NMR $\left(400 \mathrm{MHz}, \mathrm{CDCl}_{3}\right) \delta 7.85-7.82(\mathrm{~m}, 1 \mathrm{H}), 7.67-7.63(\mathrm{~m}, 1 \mathrm{H}), 7.57-$ $7.51(\mathrm{~m}, 2 \mathrm{H}), 7.50-7.46(\mathrm{~m}, 2 \mathrm{H}), 7.04(\mathrm{~d}, J=8.0 \mathrm{~Hz}, 2 \mathrm{H}), 7.01(\mathrm{~s}, 2 \mathrm{H}), 3.49-3.45(\mathrm{~m}, 4 \mathrm{H}), 2.75(\mathrm{dd}$, $J=5.6,3.8 \mathrm{~Hz}, 4 \mathrm{H}), 2.72(\mathrm{~s}, 6 \mathrm{H}), 2.32(\mathrm{~s}, 6 \mathrm{H})$.

\subsubsection{Synthesis of $\left[2\right.$-phenyl $\left(1-{ }^{13} C\right)$ ethynyl] $(2,4,6$-trimethylphenyl) iodonium $p$-toluenosulfonate (2w)}

The title compound was prepared in a following sequence.

\section{Scheme S12.}

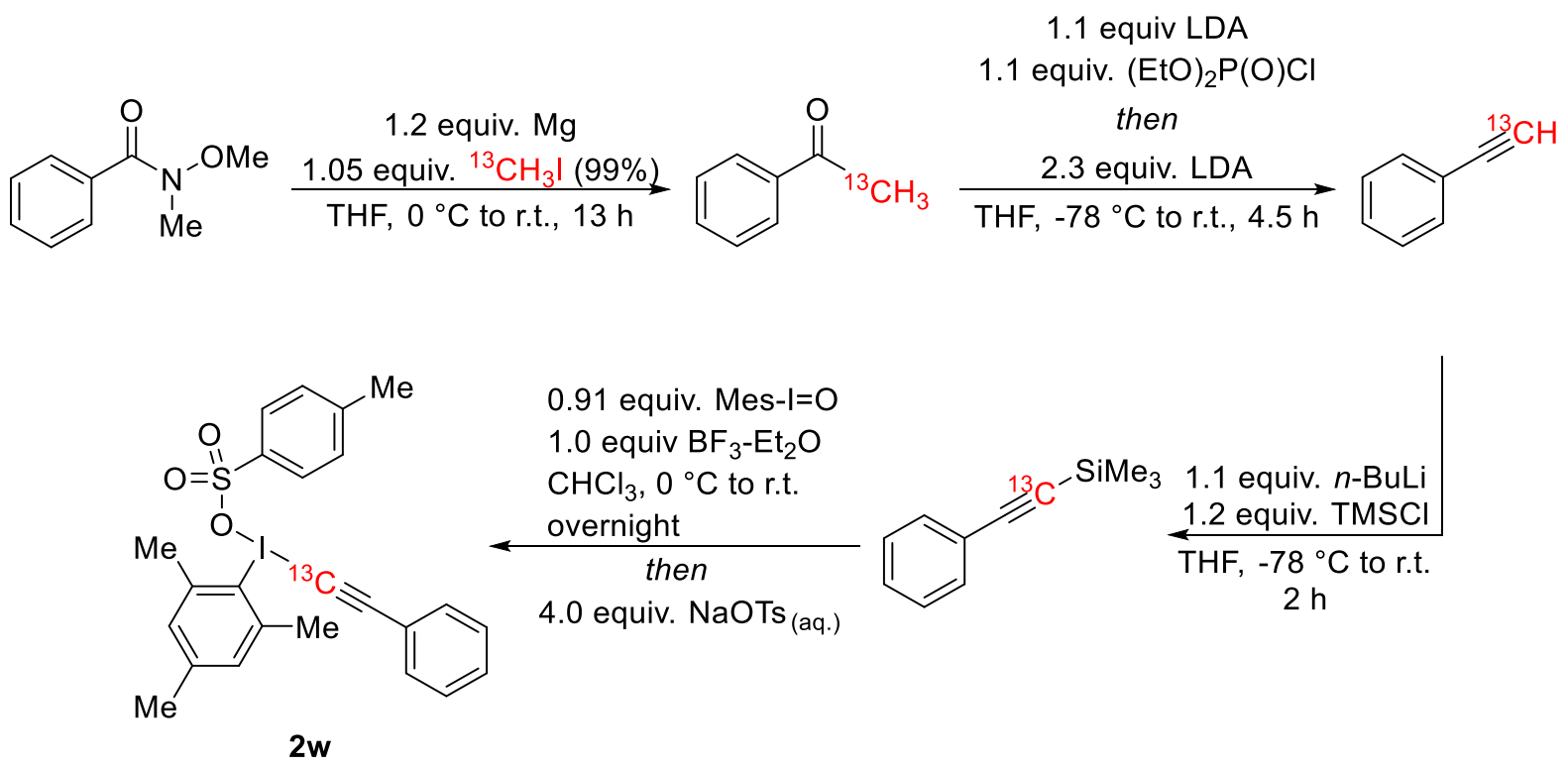

1-Phenyl $\left(2-{ }^{13} \mathrm{C}\right)$ ethan-1-one. ${ }^{39}$ Under nitrogen atmosphere, $\left[{ }^{13} \mathrm{C}\right]$-iodomethane $\left(99 \%{ }^{13} \mathrm{C} ; 1.09 \mathrm{~mL}\right.$, $17.3 \mathrm{mmol}$,) was added via syringe to a stirred suspension of magnesium turnings ( $486 \mathrm{mg}, 19.8 \mathrm{mmol}$ ) in $\mathrm{Et}_{2} \mathrm{O}$ (anhydrous, $33 \mathrm{~mL}$ ) at $0{ }^{\circ} \mathrm{C}$. After the addition was complete, the cooling bath was removed and the reaction mixture was stirred at room temperature for $2 \mathrm{~h}$, providing a solution of $\left[{ }^{13} \mathrm{C}\right]-$

${ }^{39}$ Zeng, M.; Li, L.; Herzon, S. B. J. Am. Chem. Soc. 2014, 136, 7058-7067. 
methylmagnesium iodide (nominally $0.5 \mathrm{M}$ ). This solution was transferred to a dropping funnel via a cannula under nitrogen overpressure and it was slowly added to a solution of $\mathrm{N}$-methoxy- $\mathrm{N}$ methylbenzamide $(2.73 \mathrm{~g}, 16.5 \mathrm{mmol})$ in THF (anhydrous, $23 \mathrm{~mL}$ ) over a period of 20 minutes at $0{ }^{\circ} \mathrm{C}$ under nitrogen atmosphere. Upon the completion of the addition, the cooling bath was removed and the reaction mixture was stirred at room temperature for $13 \mathrm{~h}$. Next, saturated aqueous $\mathrm{NH}_{4} \mathrm{Cl}(30 \mathrm{~mL})$ was added, the biphasic mixture was transferred to a separatory funnel, and the aqueous layer was discarded. The organic phase was washed sequentially with water $(30 \mathrm{~mL})$ and brine $(30 \mathrm{~mL})$, and it was dried over anhydrous $\mathrm{Na}_{2} \mathrm{SO}_{4}$, filtered, and concentrated under reduced pressure. The product was purified by column chromatography (silica, petroleum ether:diethyl ether/18:2 to 17:3) and it was obtained as a colorless liquid (1.47 g, 73\% yield). ${ }^{1} \mathrm{H}$ NMR $\left(400 \mathrm{MHz}, \mathrm{CDCl}_{3}\right) \delta 7.98-7.94(\mathrm{~m}, 2 \mathrm{H}), 7.59-7.54(\mathrm{~m}$, $1 \mathrm{H}), 7.50-7.43(\mathrm{~m}, 2 \mathrm{H}), 2.61\left(\mathrm{~d},{ }^{1} J_{13 \mathrm{C}-H}=127.5 \mathrm{~Hz}, 3 \mathrm{H}\right) .{ }^{13} \mathrm{C} \mathrm{NMR}\left(101 \mathrm{MHz}, \mathrm{CDCl}_{3}\right) \delta 198.1,137.3$, $133.2,128.7,128.4,26.8\left({ }^{13} \mathrm{C}\right.$ label $)$. The spectral data are in accordance with literature. ${ }^{39}$

$\left[\left(2-{ }^{13} \boldsymbol{C}\right)\right.$ Ethynyl]benzene. ${ }^{39}$ An oven-dried round bottom flask was capped with septum and evacuated/back-filled with nitrogen 3 times, a freshly prepared solution of LDA in THF (1 M, $13.2 \mathrm{~mL}$, $13.2 \mathrm{mmol}$ ) was added, and the flask was cooled down to $-78{ }^{\circ} \mathrm{C}$. Next, the solution of 1-phenyl(2${ }^{13} \mathrm{C}$ )ethan-1-one (1.47 g, $12 \mathrm{mmol}$ ) in THF (anhydrous, $7.2 \mathrm{~mL}$ ) was added dropwise via syringe. Upon completion of the addition, the mixture was stirred at $-78^{\circ} \mathrm{C}$ for $1 \mathrm{~h}$. Next, diethylchlorophosphate $(1.97$ $\mathrm{mL}, 13.2 \mathrm{mmol}$ ) was added dropwise via syringe and the resulting mixture was warmed to room temperature over $30 \mathrm{~min}$. The reaction mixture was transferred via cannula under nitrogen overpressure to a freshly prepared solution of LDA in THF $(1 \mathrm{M}, 27.6 \mathrm{~mL}, 27.6 \mathrm{mmol})$ cooled to $-78{ }^{\circ} \mathrm{C}$. After the addition was complete, the reaction mixture was gradually warmed up to room temperature over $3 \mathrm{~h}$. Water $(40 \mathrm{~mL})$ was added and the biphasic mixture was transferred to a separatory funnel. The organic layer was separated and the aqueous layer was extracted with petroleum ether $(50 \mathrm{~mL})$. The combined organic phases were washed sequentially with water $(50 \mathrm{~mL})$ and saturated aqueous $\mathrm{NaHCO}_{3}(50 \mathrm{~mL})$, dried with anhydrous $\mathrm{Na}_{2} \mathrm{SO}_{4}$, filtered, and concentrated under reduced pressure. The product was purified by column chromatography (silica, petroleum ether) and it was obtained as a colorless liquid (437 mg, 35\% yield). ${ }^{1} \mathrm{H}$ NMR (400 MHz, $\left.\mathrm{CDCl}_{3}\right) \delta 7.53-7.48(\mathrm{~m}, 2 \mathrm{H}), 7.38-7.30(\mathrm{~m}, 3 \mathrm{H}), 3.08(\mathrm{~d}$, $\left.J_{13 C-H}=251.2 \mathrm{~Hz}, 1 \mathrm{H}\right) .{ }^{13} \mathrm{C} \mathrm{NMR}\left(101 \mathrm{MHz}, \mathrm{CDCl}_{3}\right) \delta 132.3(\mathrm{~d}, J=2.7 \mathrm{~Hz}), 128.9(\mathrm{~d}, J=0.9 \mathrm{~Hz})$, $128.4,122.2,84.1(\mathrm{~d}, J=139.2 \mathrm{~Hz}), 77.3\left({ }^{13} \mathrm{C}\right.$ label $)$. The spectral data are in accordance with literature. ${ }^{39}$

Trimethyl[2-phenyl(1-13 $\mathrm{C})$ ethynyl]silane. ${ }^{40}$ Under nitrogen atmosphere, a solution of $n$-BuLi in hexanes $(2.5 \mathrm{M}, 1.87 \mathrm{~mL}, 4.66 \mathrm{mmol})$ was added dropwise via syringe to solution of [(2${ }^{13} \mathrm{C}$ )ethynyl]benzene (437 mg, $4.24 \mathrm{mmol}$ ) in THF (anhydrous, $4.2 \mathrm{~mL}$ ) at $-78{ }^{\circ} \mathrm{C}$. After stirring for 30 min at $-78{ }^{\circ} \mathrm{C}$, trimethylsilyl chloride $(0.65 \mathrm{~mL}, 5.09 \mathrm{mmol})$ was added dropwise via syringe over a period of $10 \mathrm{~min}$. The reaction mixture was stirred at $-78^{\circ} \mathrm{C}$ for 30 minutes and for further 1.5 hour at room temperature. Next, the reaction mixture was cooled down to $0{ }^{\circ} \mathrm{C}$, and saturated aqueous $\mathrm{NH}_{4} \mathrm{Cl}$ $(10 \mathrm{~mL})$ was added. The biphasic mixture was transferred to a separatory funnel and the organic layer was separated. The aqueous phase was extracted with $\mathrm{Et}_{2} \mathrm{O}(2 \times 10 \mathrm{~mL})$ and the combined organic phases were washed with brine $(10 \mathrm{~mL})$, dried over anhydrous $\mathrm{Na}_{2} \mathrm{SO}_{4}$, filtered, and concentrated under reduced pressure. The residue was dissolved in petroleum ether $(5 \mathrm{~mL})$ and it was filtered through a short pad of silica using petroleum ether $(20 \mathrm{~mL})$. After concentration under reduced pressure, the product obtained as a colorless oil, that was used in the next step without further purification (595 mg, $90 \%$ yield). ${ }^{1} \mathrm{H}$ NMR $\left(400 \mathrm{MHz}, \mathrm{CDCl}_{3}\right) \delta 7.49-7.44(\mathrm{~m}, 2 \mathrm{H}), 7.33-7.27(\mathrm{~m}, 3 \mathrm{H}), 0.25\left(\mathrm{~d}, J_{13 \mathrm{C}-H}=2.7 \mathrm{~Hz}, 9 \mathrm{H}\right) .{ }^{13} \mathrm{C}$ NMR $\left(101 \mathrm{MHz}, \mathrm{CDCl}_{3}\right) \delta 132.1(\mathrm{~d}, J=2.3 \mathrm{~Hz}), 128.6(\mathrm{~d}, J=0.8 \mathrm{~Hz}), 128.3,123.3,105.3(\mathrm{~d}, J=135.9$ $\mathrm{Hz}), 94.2\left({ }^{13} \mathrm{C}\right.$ label $), 0.1(\mathrm{~d}, J=5.5 \mathrm{~Hz})$.

\footnotetext{
${ }^{40}$ Boelke, A.; Caspers, L. D.; Nachtsheim, B. J. Org. Lett. 2017, 19, 5344-5347.
} 
[2-Phenyl $\left(1-{ }^{13} C\right)$ ethynyl](2,4,6-trimethylphenyl) iodonium $p$-toluenosulfonate $(2 \mathrm{w}){ }^{35}$ The title compound was prepared according to General Procedure 2 in $3.08 \mathrm{mmol}$ scale from iodosylmesitylene (807 mg, $3.08 \mathrm{mmol})$, trimethyl[2-phenyl $\left(1-{ }^{13} \mathrm{C}\right)$ ethynyl]silane $(595 \mathrm{mg}, 3.39 \mathrm{mmol})$, and boron trifluoride etherate $(442 \mu \mathrm{L}, 3.39 \mathrm{mmol})$ in $6 \mathrm{~mL}$ of $\mathrm{CHCl}_{3}$, using $12 \mathrm{~mL}$ of $1 \mathrm{M}$ aqueous sodium $p$ toluenosulfonate $(2.39 \mathrm{~g}, 12.3 \mathrm{mmol})$ in the second step. The product was precipitated from $6 \mathrm{~mL}$ of $\mathrm{Et}_{2} \mathrm{O}$ and after drying under high vacuum it was obtained as a yellowish solid (947 mg, 61\% yield). ${ }^{1} \mathrm{H}$ NMR (400 MHz, CDCl $) \delta 7.53-7.48(\mathrm{~m}, 2 \mathrm{H}), 7.43-7.37(\mathrm{~m}, 3 \mathrm{H}), 7.36-7.30(\mathrm{~m}, 2 \mathrm{H}), 7.05(\mathrm{~d}, J=$ $8.0 \mathrm{~Hz}, 2 \mathrm{H}), 7.03(\mathrm{~s}, 2 \mathrm{H}), 2.73(\mathrm{~s}, 6 \mathrm{H}), 2.33(\mathrm{~s}, 3 \mathrm{H}), 2.32(\mathrm{~s}, 3 \mathrm{H}) .{ }^{13} \mathrm{C} \mathrm{NMR}\left(126 \mathrm{MHz}, \mathrm{CDCl}_{3}\right) \delta 143.4$, 141.5, 141.1, 139.9, 132.9 (d, $J=3.7 \mathrm{~Hz}), 130.6,129.8,128.5(\mathrm{~d}, J=9.0 \mathrm{~Hz}), 127.8,126.0,120.4,120.4$, $102.0(\mathrm{~d}, J=168.2 \mathrm{~Hz}), 37.2\left({ }^{13} \mathrm{C}\right.$ label $), 27.1,21.4,21.1 .{ }^{13} \mathrm{C}$ NMR spectra without NOE shows that the compound contains $99 \%{ }^{13} \mathrm{C}$ at the $\alpha$-position. FT-IR-ATR: 3038, 2981, 2916, 2128, 1443, 1380, 1225 , 1157, 1142, 1116, 1003, 758, 690, $679 \mathrm{~cm}^{-1}$. HRMS (ESI): $\mathrm{m} / \mathrm{z} 348.0323\left([\mathrm{M}]^{+}, \mathrm{C}_{16}{ }^{13} \mathrm{CH}_{16} \mathrm{I}^{+}\right.$calcd. $348.0325)$.

\section{NHC-Catalyzed Propargylation of Aldehydes with Alkynyliodonium Salts}

\section{General Procedure 3}

An oven-dried $20 \mathrm{~mL}$ vial was charged with catalyst precursolr NHC-1 (18 mg, $0.05 \mathrm{mmol}, 10$ mol\%), alkynyl(2,4,6-trimethylphenyl)iodonium $p$-toluenosulfonate $2(0.60 \mathrm{mmol})$ and aldehyde $\mathbf{1}$ $(0.50 \mathrm{mmol})$. The vial was capped and evacuated/back-filled with nitrogen three times. Toluene (anhydrous, $10 \mathrm{~mL}$ ) was added via syringe, and the vial was cooled to $-40^{\circ} \mathrm{C}$. Next, TMEDA $(112 \mu \mathrm{L}$, $0.75 \mathrm{mmol}$ ) was added via syringe, and the reaction mixture was stirred at $-40{ }^{\circ} \mathrm{C}$ for $24 \mathrm{~h}$. After warming to room temperature, the reaction mixture was concentrated under reduced pressure. The product was purified by column chromatography. The procedure could be scaled-up to $6.0 \mathrm{mmol}$ of aldehyde without loss in yield (see compound $\mathbf{3 y}$ ).

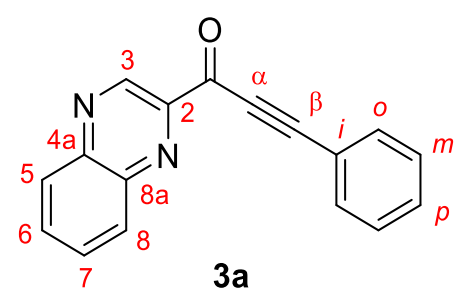

3-Phenyl-1-(quinoxalin-2-yl)prop-2-yn-1-one (3a). The title compound was prepared according to the General Procedure 3 from quinoxaline-2-carbaldehyde (1a) and (2-phenylethynyl)(2,4,6trimethylphenyl)iodonium $p$-toluenosulfonate (2a). After purification by column chromatography (silica, petroleum ether:ethyl acetate/9:1 to 8:2), the product was obtained as a yellow solid (103 mg, $80 \%$ yield). $\mathrm{R}_{\mathrm{f}}=0.46$ (petroleum ether:ethyl acetate/8:2). ${ }^{1} \mathrm{H} \mathrm{NMR}\left(400 \mathrm{MHz}, \mathrm{CDCl}_{3}\right) \delta 9.60(\mathrm{~s}, 1 \mathrm{H}$, $\left.H^{3}\right), 8.33\left(\mathrm{dd}, J=8.2,1.3 \mathrm{~Hz}, 1 \mathrm{H}, H^{8}\right), 8.20\left(\mathrm{dd}, J=8.3,1.3 \mathrm{~Hz}, 1 \mathrm{H}, H^{5}\right), 7.91$ (dddd, $J=18.7,8.3,6.9$, $\left.1.5 \mathrm{~Hz}, 2 \mathrm{H}, H^{6}, H^{7}\right), 7.80-7.76\left(\mathrm{~m}, 2 \mathrm{H}, H^{o}\right), 7.55-7.49\left(\mathrm{~m}, 1 \mathrm{H}, H^{p}\right), 7.48-7.43\left(\mathrm{~m}, 2 \mathrm{H}, H^{m}\right) .{ }^{13} \mathrm{C}$ NMR $\left(126 \mathrm{MHz}, \mathrm{CDCl}_{3}\right) \delta 177.6\left(C^{C=O}\right), 147.0\left(C^{2}\right), 144.1\left(C^{8 a}\right), 143.7\left(\mathrm{~d}, J=20.1 \mathrm{~Hz}, C^{3}\right), 141.6\left(C^{4 a}\right)$, $133.8\left(C^{o}\right), 132.8\left(C^{6}\right), 131.4\left(C^{p}\right), 131.13\left(C^{7}\right), 131.10\left(C^{8}\right), 129.6\left(C^{5}\right), 128.9\left(C^{m}\right), 120.1\left(C^{i}\right), 97.3$ $\left(C^{\beta}\right), 87.7\left(C^{\alpha}\right)$. FT-IR-ATR: 3053, 3036, 2195, 1638, 1326, 1202, 1130, 965, 766, 751, $687 \mathrm{~cm}^{-1}$. HRMS (ESI): $m / z 259.0865\left([\mathrm{M}+\mathrm{H}]^{+}, \mathrm{C}_{17} \mathrm{H}_{11} \mathrm{~N}_{2} \mathrm{O}^{+}\right.$calcd. 259.0866). 


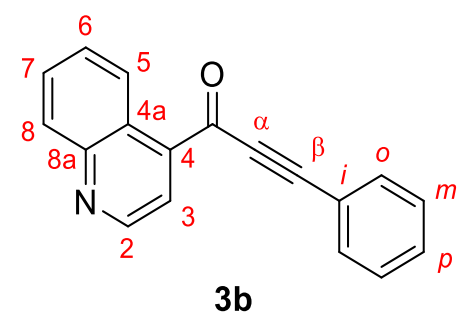

3-Phenyl-1-(quinolin-4-yl)prop-2-yn-1-one (3b). The title compound was prepared according to the General Procedure 3 from quinoline-4-carbaldehyde (1b) and (2-phenylethynyl)(2,4,6trimethylphenyl)iodonium $p$-toluenosulfonate (2a). After purification by column chromatography (silica, petroleum ether:ethyl acetate/8:2 to 1:1), the product was obtained as a red solid $(83 \mathrm{mg}, 65 \%$ yield). $\mathrm{R}_{\mathrm{f}}=0.16$ (petroleum ether:ethyl acetate/8:2). ${ }^{1} \mathrm{H} \mathrm{NMR}\left(400 \mathrm{MHz}, \mathrm{CDCl}_{3}\right) \delta 9.16(\mathrm{~d}, J=4.4 \mathrm{~Hz}$, $\left.1 \mathrm{H}, H^{2}\right), 8.98\left(\mathrm{~d}, J=8.6 \mathrm{~Hz}, 1 \mathrm{H}, H^{5}\right), 8.26\left(\mathrm{~d}, J=4.4 \mathrm{~Hz}, 1 \mathrm{H}, H^{3}\right), 8.23\left(\mathrm{~d}, J=8.4 \mathrm{~Hz}, 1 \mathrm{H}, H^{8}\right), 7.82$ (ddd, $\left.J=8.3,7.0,1.3 \mathrm{~Hz}, 1 \mathrm{H}, H^{7}\right), 7.72\left(\mathrm{ddd}, J=15.2,7.7,1.3 \mathrm{~Hz}, 3 \mathrm{H}, H^{o}, H^{6}\right), 7.54-7.50(\mathrm{~m}, 1 \mathrm{H}$, $\left.H^{p}\right), 7.45\left(\mathrm{t}, J=7.5 \mathrm{~Hz}, 2 \mathrm{H}, H^{m}\right) .{ }^{13} \mathrm{C}$ NMR $\left(126 \mathrm{MHz}, \mathrm{CDCl}_{3}\right) \delta 179.1\left(C^{C=O}\right), 149.9\left(C^{2}\right), 149.2\left(C^{8 a}\right)$, 134.0 $\left(C^{4}\right), 133.4\left(C^{o}\right), 131.5\left(C^{p}\right), 130.3\left(C^{7}\right), 130.0\left(C^{8}\right), 129.3\left(C^{6}\right), 129.0\left(C^{m}\right), 125.7\left(C^{5}\right), 124.2\left(C^{3}\right)$, $119.7\left(C^{i}\right), 94.0\left(C^{\beta}\right), 88.2\left(C^{\alpha}\right)$. The spectral data are in accordance with literature. ${ }^{41}$

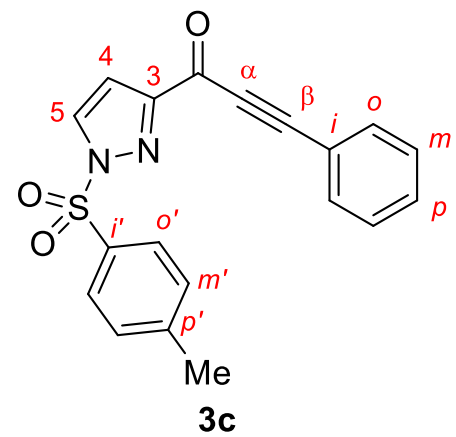

1-[1-(4-Methylbenzenesulfonyl)-1H-pyrazol-3-yl]-3-phenylprop-2-yn-1-one $\quad$ (3c). The title compound was prepared according to the General Procedure 3 from 1-(4-methylbenzenesulfonyl)- $1 \mathrm{H}$ pyrazole-3-carbaldehyde (1c) and (2-phenylethynyl)(2,4,6-trimethylphenyl)iodonium $p$ toluenosulfonate (2a). After purification by column chromatography (silica, petroleum ether:ethyl acetate/9:1 to 8:2), the product was obtained as a yellow solid (139 $\mathrm{mg}, 79 \%$ yield). $\mathrm{R}_{\mathrm{f}}=0.42$ (petroleum ether:ethyl acetate/8:2). ${ }^{1} \mathrm{H}$ NMR $\left(400 \mathrm{MHz}, \mathrm{CDCl}_{3}\right) \delta 8.15\left(\mathrm{~d}, J=2.8 \mathrm{~Hz}, 1 \mathrm{H}, H^{5}\right), 8.02-7.97(\mathrm{~m}, 2 \mathrm{H}$, $\left.H^{o^{\prime}}\right), 7.69-7.64\left(\mathrm{~m}, 2 \mathrm{H}, H^{o}\right), 7.53-7.48\left(\mathrm{~m}, 1 \mathrm{H}, H^{p}\right), 7.46-7.41\left(\mathrm{~m}, 2 \mathrm{H}, H^{m}\right), 7.39-7.34(\mathrm{~m}, 2 \mathrm{H}$, $\left.H^{m}\right), 6.94\left(\mathrm{~d}, J=2.8 \mathrm{~Hz}, 1 \mathrm{H}, H^{4}\right), 2.43\left(\mathrm{~s}, 3 \mathrm{H}, \mathrm{CH}_{3}\right) .{ }^{13} \mathrm{C}$ NMR $\left(126 \mathrm{MHz}, \mathrm{CDCl}_{3}\right) \delta 171.5\left(C^{C=O}\right), 155.3$ $\left(C^{3}\right), 146.9\left(C^{p^{\prime}}\right), 133.6\left(C^{o}\right), 133.3\left(C^{i^{\prime}}\right), 132.3\left(C^{5}\right), 131.2\left(C^{p}\right), 130.4\left(C^{m}\right), 128.81,128.80\left(C^{o^{\prime}}, C^{m}\right)$, $120.1\left(C^{i}\right), 108.8\left(C^{4}\right), 94.4\left(C^{\beta}\right), 87.2\left(C^{\alpha}\right), 21.9\left(C_{3}\right)$. FT-IR-ATR: 3140, 3125, 2925, 2201, 1646, 1382, 1196, 1120, 1074, 1034, 959, 798, 756, $668 \mathrm{~cm}^{-1}$. HRMS (ESI): $\mathrm{m} / z 351.0796\left([\mathrm{M}+\mathrm{H}]^{+}\right.$, $\mathrm{C}_{19} \mathrm{H}_{15} \mathrm{~N}_{2} \mathrm{O}_{3} \mathrm{~S}^{+}$calcd. 351.0798).

\footnotetext{
${ }^{41}$ Boersch, C.; Merkul, E.; Müller, T. J. J. Angew. Chem. Int. Ed. 2011, 50, 10448-10452.
} 


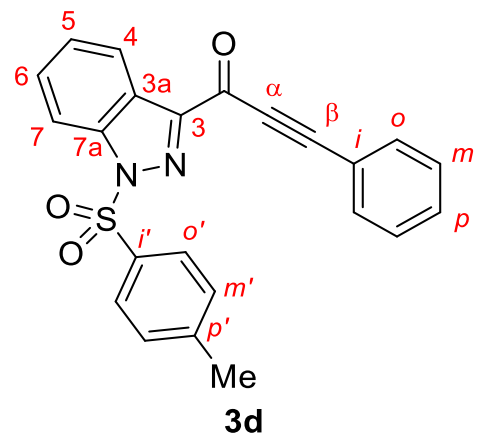

1-[1-(4-Methylbenzenesulfonyl)-1H-indazol-3-yl]-3-phenylprop-2-yn-1-one $\quad$ (3d). The title compound was prepared according to the General Procedure 3 from 1-(4-methylbenzenesulfonyl)- $1 \mathrm{H}$ indazole-3-carbaldehyde (1d) and (2-phenylethynyl)(2,4,6-trimethylphenyl)iodonium $p$ toluenosulfonate (2a). After purification by column chromatography (silica, petroleum ether:ethyl acetate/18:2 to 17:3), the product was obtained as a yellowish solid (169 $\mathrm{mg}, 84 \%$ yield). $\mathrm{R}_{\mathrm{f}}=0.52$ (petroleum ether:ethyl acetate/8:2). ${ }^{1} \mathrm{H}$ NMR $\left(400 \mathrm{MHz}, \mathrm{CDCl}_{3}\right) \delta 8.34\left(\mathrm{~d}, J=8.1 \mathrm{~Hz}, 1 \mathrm{H}, H^{4}\right), 8.25(\mathrm{~d}$, $\left.J=8.6 \mathrm{~Hz}, 1 \mathrm{H}, H^{7}\right), 7.99\left(\mathrm{~d}, J=8.4 \mathrm{~Hz}, 2 \mathrm{H}, H^{\circ}\right), 7.78-7.73\left(\mathrm{~m}, 2 \mathrm{H}, H^{o}\right), 7.61(\mathrm{ddd}, J=8.4,7.1,1.1$ $\left.\mathrm{Hz}, 1 \mathrm{H}, H^{6}\right), 7.55-7.50\left(\mathrm{~m}, 1 \mathrm{H}, H^{p}\right), 7.49-7.42\left(\mathrm{~m}, 3 \mathrm{H}, \mathrm{H} 5, H^{m}\right), 7.29\left(\mathrm{~d}, J=8.2 \mathrm{~Hz}, 2 \mathrm{H}, H^{m^{\prime}}\right), 2.37$ (s, 3H, $\left.\mathrm{CH}_{3}\right) .{ }^{13} \mathrm{C}$ NMR $\left(126 \mathrm{MHz}, \mathrm{CDCl}_{3}\right) \delta 172.6\left(C^{C=O}\right), 148.0,141.6\left(C^{3}, C^{7 a}\right), 146.3\left(C^{p^{\prime}}\right), 134.2$ $\left(C^{i^{\prime}}\right), 133.6\left(C^{o}\right), 131.2\left(C^{p}\right), 130.2\left(C^{m}\right), 129.8\left(C^{6}\right), 128.8\left(C^{m}\right), 128.2\left(C^{o}\right), 126.0\left(C^{5}\right), 123.4\left(C^{3 a}\right)$, 123.0 $\left(C^{4}\right), 120.2\left(C^{i}\right), 113.2\left(C^{7}\right), 94.5\left(C^{\beta}\right), 87.4\left(C^{\alpha}\right), 21.8\left(C_{3}\right)$. FT-IR-ATR: 3086, 3037, 2921, $2195,1642,1473,1272,1128,1082,950,749 \mathrm{~cm}^{-1}$. HRMS (ESI): $\mathrm{m} / z 401.0954\left([\mathrm{M}+\mathrm{H}]^{+}, \mathrm{C}_{23} \mathrm{H}_{17} \mathrm{~N}_{2} \mathrm{O}_{3} \mathrm{~S}^{+}\right.$ calcd. 401.0954).

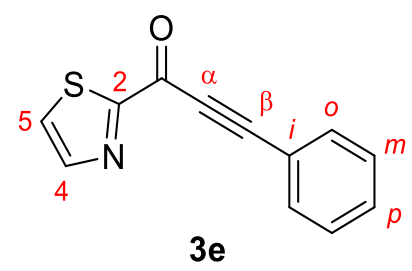

3-Phenyl-1-(1,3-thiazol-2-yl)prop-2-yn-1-one (3e). The title compound was prepared according to the General Procedure 3 from 1,3-thiazole-2-carbaldehyde (1e) and (2-phenylethynyl)(2,4,6trimethylphenyl)iodonium $p$-toluenosulfonate (2a). After purification by column chromatography (silica, petroleum ether:ethyl acetate/18:2 to 17:3), the product was obtained as a yellow solid (90 $\mathrm{mg}$, $84 \%$ yield). $\mathrm{R}_{\mathrm{f}}=0.42$ (petroleum ether:ethyl acetate/8:2). ${ }^{1} \mathrm{H} \mathrm{NMR}\left(400 \mathrm{MHz}, \mathrm{CDCl}_{3}\right) \delta 8.13(\mathrm{~d}, J=3.0$ $\left.\mathrm{Hz}, 1 \mathrm{H}, H^{4}\right), 7.74\left(\mathrm{~d}, J=3.0 \mathrm{~Hz}, 1 \mathrm{H}, H^{5}\right), 7.73-7.70\left(\mathrm{~m}, 2 \mathrm{H}, H^{o}\right), 7.51-7.46\left(\mathrm{~m}, 1 \mathrm{H}, H^{p}\right), 7.43-7.38$ $\left(\mathrm{m}, 2 \mathrm{H}, H^{m}\right) .{ }^{13} \mathrm{C}$ NMR $\left(126 \mathrm{MHz}, \mathrm{CDCl}_{3}\right) \delta 169.8\left(C^{C=O}\right), 166.9\left(C^{2}\right), 145.8\left(C^{5}\right), 133.6\left(C^{o}\right), 131.4$ $\left(C^{p}\right), 128.8\left(C^{m}\right), 126.8\left(C^{4}\right), 119.7\left(C^{i}\right), 95.9\left(C^{\beta}\right), 86.6\left(C^{\alpha}\right)$. FT-IR-ATR: 3103, 3085, 2186, 1630, 1384, 1325, 1310, 1216, 1062, 977, 750, $679 \mathrm{~cm}^{-1}$. HRMS (ESI): $\mathrm{m} / z 214.0321\left([\mathrm{M}+\mathrm{H}]^{+}, \mathrm{C}_{12} \mathrm{H}_{8} \mathrm{NOS}^{+}\right.$calcd. 214.0321).

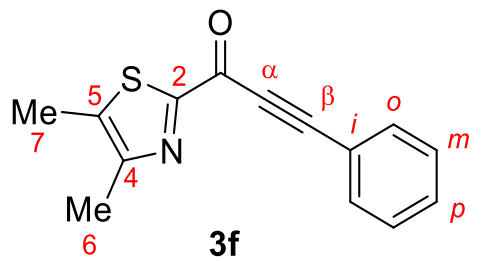

1-(4,5-Dimethyl-1,3-thiazol-2-yl)-3-phenylprop-2-yn-1-one (3f). The title compound was prepared according to the General Procedure 3 from 4,5-dimethyl-1,3-thiazole-2-carbaldehyde (1f) and (2- 
phenylethynyl)(2,4,6-trimethylphenyl)iodonium $p$-toluenosulfonate (2a). After purification by column chromatography (silica, petroleum ether:ethyl acetate/18:2 to 17:3), the product was obtained as a yellow solid (108 mg, 90\% yield). $\mathrm{R}_{\mathrm{f}}=0.46$ (petroleum ether:ethyl acetate/8:2). ${ }^{1} \mathrm{H} \mathrm{NMR}(400 \mathrm{MHz}$, $\left.\mathrm{CDCl}_{3}\right) \delta 7.73-7.70\left(\mathrm{~m}, 2 \mathrm{H}, H^{o}\right), 7.51-7.46\left(\mathrm{~m}, 1 \mathrm{H}, H^{p}\right), 7.44-7.39\left(\mathrm{~m}, 2 \mathrm{H}, H^{m}\right), 2.49(\mathrm{~d}, J=0.5 \mathrm{~Hz}$, $\left.3 \mathrm{H}, H^{7}\right), 2.48\left(\mathrm{~d}, J=0.6 \mathrm{~Hz}, 3 \mathrm{H}, H^{6}\right) .{ }^{13} \mathrm{C}$ NMR $\left(126 \mathrm{MHz}, \mathrm{CDCl}_{3}\right) \delta 169.2\left(C^{C=O}\right), 161.4\left(C^{2}\right), 153.0$ $\left(C^{4}\right), 137.1\left(C^{5}\right), 133.5\left(C^{o}\right), 131.1\left(C^{p}\right), 128.7\left(C^{m}\right), 120.0\left(C^{i}\right), 94.7\left(C^{\beta}\right), 86.8\left(C^{\alpha}\right), 15.1\left(C^{6}\right), 12.3\left(C^{7}\right)$. FT-IR-ATR: 3067, 2923, 2855, 2195, 1616, 1419, 1308, 1285, 1175, 966, 763, $689 \mathrm{~cm}^{-1}$. HRMS (ESI): $m / z 242.0634\left([\mathrm{M}+\mathrm{H}]^{+}, \mathrm{C}_{14} \mathrm{H}_{12} \mathrm{NOS}^{+}\right.$calcd. 242.0634).

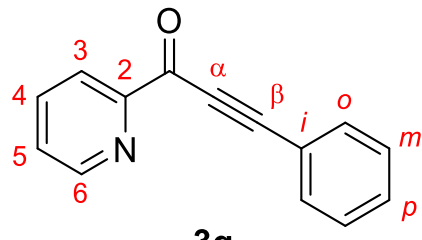

$3 g$

3-Phenyl-1-(pyridin-2-yl)prop-2-yn-1-one (3g). The title compound was prepared according to the General Procedure 3 from pyridine-2-carbaldehyde (1g) and (2-phenylethynyl)(2,4,6trimethylphenyl)iodonium $p$-toluenosulfonate (2a). After purification by column chromatography (silica, petroleum ether:ethyl acetate/18:2 to 17:3), the product was obtained as a yellow liquid (96 mg, 93\% yield) which turned to blue color upon standing. $\mathrm{R}_{\mathrm{f}}=0.33$ (petroleum ether:ethyl acetate/8:2). ${ }^{1} \mathrm{H}$ $\operatorname{NMR}\left(400 \mathrm{MHz}, \mathrm{CDCl}_{3}\right) \delta 8.84\left(\mathrm{ddd}, J=4.7,1.7,0.9 \mathrm{~Hz}, 1 \mathrm{H}, H^{6}\right), 8.21-8.17\left(\mathrm{~m}, 1 \mathrm{H}, H^{3}\right), 7.92-7.86$ $\left(\mathrm{m}, 1 \mathrm{H}, H^{4}\right), 7.74\left(\mathrm{ddd}, J=6.9,3.5,1.7 \mathrm{~Hz}, 2 \mathrm{H}, H^{\circ}\right), 7.53\left(\mathrm{ddd}, J=7.6,4.7,1.2 \mathrm{~Hz}, 1 \mathrm{H}, H^{5}\right), 7.51-7.46$ $\left(\mathrm{m}, 1 \mathrm{H}, H^{p}\right), 7.44-7.39\left(\mathrm{~m}, 2 \mathrm{H}, H^{m}\right) .{ }^{13} \mathrm{C}$ NMR $\left(126 \mathrm{MHz}, \mathrm{CDCl}_{3}\right) \delta 178.3\left(C^{C=O}\right), 153.3\left(C^{2}\right), 150.0$ $\left(C^{6}\right), 137.1\left(C^{4}\right), 133.5\left(C^{o}\right), 131.0\left(C^{p}\right), 128.7\left(C^{m}\right), 127.6\left(C^{5}\right), 123.5\left(C^{3}\right), 120.3\left(C^{i}\right), 95.6\left(C^{\beta}\right), 88.0$ $\left(C^{\alpha}\right)$. The spectral data are in accordance with literature. ${ }^{42}$

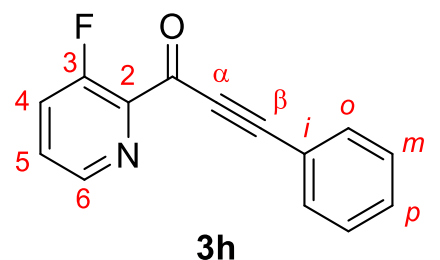

1-(3-Fluoropyridin-2-yl)-3-phenylprop-2-yn-1-one (3h). The title compound was prepared according to the General Procedure 3 from 3-fluoropyridine-2-carbaldehyde (1h) and (2-phenylethynyl)(2,4,6trimethylphenyl)iodonium $p$-toluenosulfonate (2a). After purification by column chromatography (silica, petroleum ether:ethyl acetate/16:4 to 12:8), the product was obtained as a brownish solid $(90 \mathrm{mg}$, $80 \%$ yield). $\mathrm{R}_{\mathrm{f}}=0.26$ (petroleum ether:ethyl acetate/8:2). ${ }^{1} \mathrm{H}$ NMR $\left(400 \mathrm{MHz}, \mathrm{CDCl}_{3}\right) \delta 8.65-8.62(\mathrm{~m}$, $\left.1 \mathrm{H}, H^{6}\right), 7.72-7.68\left(\mathrm{~m}, 2 \mathrm{H}, H^{o}\right), 7.62-7.54\left(\mathrm{~m}, 2 \mathrm{H}, H^{4}, H^{5}\right), 7.51-7.46\left(\mathrm{~m}, 1 \mathrm{H}, H^{p}\right), 7.44-7.38(\mathrm{~m}$, $\left.2 \mathrm{H}, H^{m}\right) .{ }^{13} \mathrm{C}$ NMR $\left(126 \mathrm{MHz}, \mathrm{CDCl}_{3}\right) \delta 175.1\left(\mathrm{~d}, J=5.2 \mathrm{~Hz}, C^{C=O}\right), 159.4\left(\mathrm{~d}, J=274.5 \mathrm{~Hz}, C^{3}\right), 145.5$ $\left(\mathrm{d}, J=5.3 \mathrm{~Hz}, C^{\sigma}\right), 141.5\left(\mathrm{~d}, J=5.8 \mathrm{~Hz}, C^{2}\right), 133.5\left(C^{o}\right), 131.1\left(C^{p}\right), 129.1\left(\mathrm{~d}, J=5.1 \mathrm{~Hz}, C^{5}\right), 128.7$ $\left(C^{m}\right), 125.8\left(\mathrm{~d}, J=19.3 \mathrm{~Hz}, C^{4}\right), 120.1\left(C^{i}\right), 95.1\left(C^{\beta}\right), 88.6\left(C^{\alpha}\right) .{ }^{19} \mathrm{~F} \mathrm{NMR}\left(471 \mathrm{MHz}, \mathrm{CDCl}_{3}\right) \delta-119.4$ (dd, $J=9.0,4.9$ Hz). FT-IR-ATR: 3078, 2199, 1653, 1443, 1312, 1279, 1180, 1016, 994, 821, 767, 682 $\mathrm{cm}^{-1}$. HRMS (ESI): $\mathrm{m} / z 226.0663\left([\mathrm{M}+\mathrm{H}]^{+}, \mathrm{C}_{14} \mathrm{H}_{9} \mathrm{FNO}^{+}\right.$calcd. 226.0663).

\footnotetext{
${ }^{42}$ Friel, D. K.; Snapper, M. L.; Hoveyda, A. H. J. Am. Chem. Soc. 2008, 130, 9942-9951.
} 


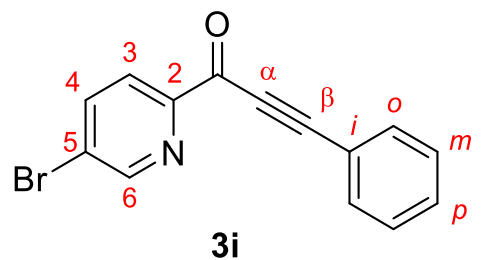

1-(5-Bromopyridin-2-yl)-3-phenylprop-2-yn-1-one (3i). The title compound was prepared according to the General Procedure 3 from 5-bromopyridine-2-carbaldehyde (1i) and (2-phenylethynyl)(2,4,6trimethylphenyl)iodonium $p$-toluenosulfonate (2a). After purification by column chromatography (silica, petroleum ether:ethyl acetate/8:2), the product was obtained as a greenish solid (129 $\mathrm{mg}, 90 \%$ yield). $\mathrm{R}_{\mathrm{f}}=0.71$ (petroleum ether:ethyl acetate/8:2). ${ }^{1} \mathrm{H} \mathrm{NMR}\left(400 \mathrm{MHz}, \mathrm{CDCl}_{3}\right) \delta 8.87(\mathrm{dd}, J=2.2$, $\left.0.8 \mathrm{~Hz}, 1 \mathrm{H}, H^{6}\right), 8.06\left(\mathrm{dd}, J=8.4,0.8 \mathrm{~Hz}, 1 \mathrm{H}, H^{3}\right), 8.02\left(\mathrm{dd}, J=8.3,2.1 \mathrm{~Hz}, 1 \mathrm{H}, H^{4}\right), 7.74-7.70(\mathrm{~m}$, $\left.2 \mathrm{H}, H^{o}\right), 7.52-7.47\left(\mathrm{~m}, 1 \mathrm{H}, H^{p}\right), 7.45-7.39\left(\mathrm{~m}, 2 \mathrm{H}, H^{m}\right) .{ }^{13} \mathrm{C} \mathrm{NMR}\left(126 \mathrm{MHz}, \mathrm{CDCl}_{3}\right) \delta 177.3\left(C^{C=O}\right)$, 151.7 $\left(C^{2}\right), 151.2\left(C^{6}\right), 139.8\left(C^{4}\right), 133.5\left(C^{o}\right), 131.1\left(C^{p}\right), 128.7\left(C^{m}\right), 126.0\left(C^{5}\right), 124.4\left(C^{3}\right), 120.1\left(C^{i}\right)$, $96.1\left(C^{\beta}\right), 87.8\left(C^{\alpha}\right)$. FT-IR-ATR: 3036, 2199, 1653, 1600, 1366, 1306, 1212, 1197, 1084, 996, 869, 750, $678 \mathrm{~cm}^{-1}$. HRMS (ESI): $\mathrm{m} / z 285.9862\left([\mathrm{M}+\mathrm{H}]^{+}, \mathrm{C}_{14} \mathrm{H}_{9} \mathrm{BrNO}^{+}\right.$calcd. 285.9862).

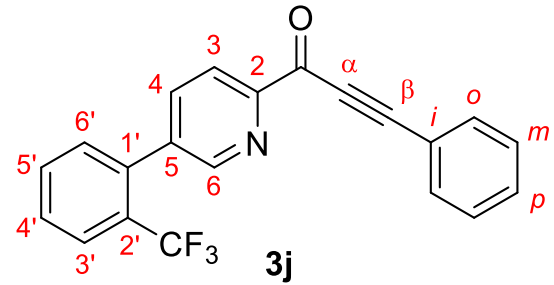

3-Phenyl-1-\{5-[2-(trifluoromethyl)phenyl]pyridin-2-yl\}prop-2-yn-1-one (3j). The title compound was prepared according to the General Procedure 3 from 5-[2-(trifluoromethyl)phenyl]pyridine-2carbaldehyde (1j) and (2-phenylethynyl)(2,4,6-trimethylphenyl)iodonium $p$-toluenosulfonate (2a). After purification by column chromatography (silica, petroleum ether:ethyl acetate/18:2 to 17:3), the product was obtained as a reddish solid $\left(169 \mathrm{mg}, 96 \%\right.$ yield). $\mathrm{R}_{\mathrm{f}}=0.20$ (petroleum ether:ethyl acetate/9:1). ${ }^{1} \mathrm{H}$ NMR $\left(400 \mathrm{MHz}, \mathrm{CDCl}_{3}\right) \delta 8.79\left(\mathrm{~d}, J=2.1 \mathrm{~Hz}, 1 \mathrm{H}, H^{6}\right), 8.25(\mathrm{dd}, J=8.0,0.8 \mathrm{~Hz}, 1 \mathrm{H}$, $\left.H^{3}\right), 7.89-7.85\left(\mathrm{~m}, 1 \mathrm{H}, H^{4}\right), 7.85-7.81\left(\mathrm{~m}, 1 \mathrm{H}, H^{3}\right), 7.77-7.73\left(\mathrm{~m}, 2 \mathrm{H}, H^{o}\right), 7.69-7.63\left(\mathrm{~m}, 1 \mathrm{H}, H^{5^{\prime}}\right)$, $7.62-7.56\left(\mathrm{~m}, 1 \mathrm{H}, H^{4}\right), 7.52-7.46\left(\mathrm{~m}, 1 \mathrm{H}, H^{p}\right), 7.45-7.39\left(\mathrm{~m}, 2 \mathrm{H}, H^{m}\right), 7.37-7.33\left(\mathrm{~m}, 1 \mathrm{H}, H^{6}\right) .{ }^{13} \mathrm{C}$ NMR $\left(126 \mathrm{MHz}, \mathrm{CDCl}_{3}\right) \delta 177.9\left(C^{C=0}\right), 152.6\left(C^{2}\right), 149.8\left(C^{6}\right), 139.6,136.6\left(C^{1}, C^{5}\right), 137.5\left(C^{4}\right)$, $133.6\left(C^{o}\right), 132.0,131.9\left(C^{5^{\prime}}, C^{6^{\prime}}\right), 131.0\left(C^{p}\right), 129.0\left(\mathrm{q}, J=30.4 \mathrm{~Hz}, C^{2}\right), 129.0\left(C^{4^{\prime}}\right), 128.7\left(C^{m}\right), 126.7$ $\left(\mathrm{q}, J=5.2 \mathrm{~Hz}, C^{3}\right), 123.9\left(\mathrm{q}, J=273.9 \mathrm{~Hz}, C \mathrm{~F}_{3}\right), 122.6\left(C^{3}\right), 120.3\left(C^{i}\right), 95.8\left(C^{\beta}\right), 88.1\left(C^{\alpha}\right) .{ }^{19} \mathrm{~F}$ NMR $\left(471 \mathrm{MHz}, \mathrm{CDCl}_{3}\right) \delta$-56.7 (s). FT-IR-ATR: 3061, 2198, 1635, 1313, 1264, 1114, 1108, 1036, 997, 760, $693 \mathrm{~cm}^{-1}$. HRMS (ESI): $\mathrm{m} / z 352.0943\left([\mathrm{M}+\mathrm{H}]^{+}, \mathrm{C}_{21} \mathrm{H}_{13} \mathrm{~F}_{3} \mathrm{NO}^{+}\right.$calcd. 352.0944).

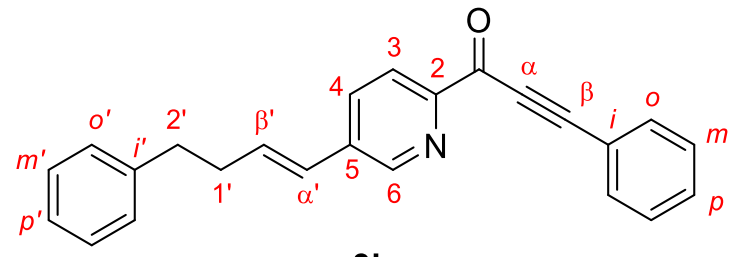

$3 \mathbf{k}$

3-Phenyl-1-\{5-[(1E)-3-phenylprop-1-en-1-yl]pyridin-2-yl\}prop-2-yn-1-one $\quad(3 \mathrm{k}) . \quad$ The title compound was prepared according to the General Procedure 3 from 5-[(1E)-4-phenylbut-1-en-1yl]pyridine-2-carbaldehyde (1k) and (2-phenylethynyl)(2,4,6-trimethylphenyl)iodonium $p$ toluenosulfonate (2a). After purification by column chromatography (silica, petroleum ether:ethyl acetate/18:2 to $17: 3$ ), the product was obtained as a yellow solid (154 mg, 91\% yield). $R_{\mathrm{f}}=0.20$ 
(petroleum ether:ethyl acetate/9:1). ${ }^{1} \mathrm{H}$ NMR $\left(400 \mathrm{MHz}, \mathrm{CDCl}_{3}\right) \delta 8.73\left(\mathrm{~d}, J=1.7 \mathrm{~Hz}, 1 \mathrm{H}, H^{6}\right), 8.12$ $\left(\mathrm{dd}, J=8.2,0.5 \mathrm{~Hz}, 1 \mathrm{H}, H^{3}\right), 7.79\left(\mathrm{dd}, J=8.2,2.2 \mathrm{~Hz}, 1 \mathrm{H}, H^{4}\right), 7.74-7.71\left(\mathrm{~m}, 2 \mathrm{H}, H^{o}\right), 7.50-7.45(\mathrm{~m}$, $\left.1 \mathrm{H}, H^{p}\right), 7.44-7.39\left(\mathrm{~m}, 2 \mathrm{H}, H^{m}\right), 7.34-7.29\left(\mathrm{~m}, 2 \mathrm{H}, H^{o}\right), 7.25-7.19\left(\mathrm{~m}, 3 \mathrm{H}, H^{p^{\prime}}, H^{m^{\prime}}\right), 6.53(\mathrm{dt}, J=$ $\left.15.9,5.8 \mathrm{~Hz}, 1 \mathrm{H}, H^{\beta^{\prime}}\right), 6.47\left(\mathrm{~d}, J=16.1 \mathrm{~Hz}, 1 \mathrm{H}, H^{\alpha^{\prime}}\right), 2.87-2.82\left(\mathrm{~m}, 2 \mathrm{H}, H^{2^{\prime}}\right), 2.65-2.59(\mathrm{~m}, 2 \mathrm{H}$, $\left.H^{l^{\prime}}\right) .{ }^{13} \mathrm{C}$ NMR $\left(126 \mathrm{MHz}, \mathrm{CDCl}_{3}\right) \delta 177.8\left(C^{C=0}\right), 151.7\left(C^{2}\right), 148.1\left(C^{6}\right), 141.2\left(C^{i^{\prime}}\right), 137.2\left(C^{5}\right), 136.1$ $\left(C^{\alpha^{\prime}}\right), 133.4\left(C^{o}\right), 133.1\left(C^{4}\right), 130.8\left(C^{m}\right), 128.6\left(C^{p}\right), 128.55,128.51\left(C^{o}, C^{m}\right), 126.5\left(C^{\beta^{\prime}}\right), 126.2\left(C^{p^{\prime}}\right)$, 123.6 $\left(C^{3}\right), 120.4\left(C^{i}\right), 95.1\left(C^{\beta}\right), 88.1\left(C^{\alpha}\right), 35.4\left(C^{2}\right), 35.1\left(C^{l^{\prime}}\right)$. FT-IR-ATR: 3058, 2927, 2853, 2199 , 1635, 1580, 1490, 1319, 1206, 1123, 1016, 963, 861, 765, $691 \mathrm{~cm}^{-1}$. HRMS (ESI): $\mathrm{m} / \mathrm{z} 338.1538$ $\left([\mathrm{M}+\mathrm{H}]^{+}, \mathrm{C}_{24} \mathrm{H}_{20} \mathrm{NO}^{+}\right.$calcd. 338.1539).

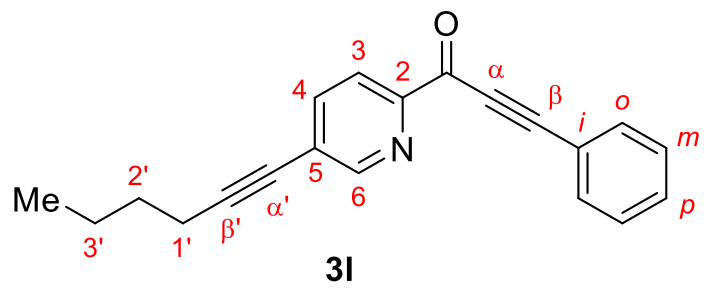

1-[5-(Hex-1-yn-1-yl)pyridin-2-yl]-3-phenylprop-2-yn-1-one (3l). The title compound was prepared according to the General Procedure 3 from 5-(hex-1-yn-1-yl)pyridine-2-carbaldehyde (11) and (2phenylethynyl)(2,4,6-trimethylphenyl)iodonium $p$-toluenosulfonate (2a). After purification by column chromatography (silica, petroleum ether:ethyl acetate/18:2 to 17:3), the product was obtained as a reddish liquid (126 mg, 88\% yield). $\mathrm{R}_{\mathrm{f}}=0.75$ (petroleum ether:ethyl acetate/8:2). ${ }^{1} \mathrm{H}$ NMR $(400 \mathrm{MHz}$, $\left.\mathrm{CDCl}_{3}\right) \delta 8.77\left(\mathrm{dd}, J=2.0,0.8 \mathrm{~Hz}, 1 \mathrm{H}, H^{6}\right), 8.10\left(\mathrm{dd}, J=8.1,0.8 \mathrm{~Hz}, 1 \mathrm{H}, H^{3}\right), 7.82(\mathrm{dd}, J=8.1,2.0 \mathrm{~Hz}$, $\left.1 \mathrm{H}, H^{4}\right), 7.74-7.70\left(\mathrm{~m}, 2 \mathrm{H}, H^{o}\right), 7.51-7.45\left(\mathrm{~m}, 1 \mathrm{H}, H^{p}\right), 7.44-7.38\left(\mathrm{~m}, 2 \mathrm{H}, H^{m}\right), 2.48(\mathrm{t}, J=7.1 \mathrm{~Hz}$, $\left.2 \mathrm{H}, H^{l}\right), 1.68-1.58\left(\mathrm{~m}, 2 \mathrm{H}, H^{2}\right), 1.55-1.45\left(\mathrm{~m}, 2 \mathrm{H}, H^{3}\right), 0.97\left(\mathrm{t}, J=7.3 \mathrm{~Hz}, 3 \mathrm{H}, \mathrm{CH}_{3}\right) .{ }^{13} \mathrm{C} \mathrm{NMR}$ $\left(126 \mathrm{MHz}, \mathrm{CDCl}_{3}\right) \delta 177.5\left(C^{C=O}\right), 152.4\left(C^{6}\right), 151.0\left(C^{2}\right), 139.3\left(C^{4}\right), 133.5\left(C^{o}\right), 131.0\left(C^{p}\right), 128.7$ $\left(C^{m}\right), 125.5\left(C^{5}\right), 122.8\left(C^{3}\right), 120.3\left(C^{i}\right), 98.6\left(C^{\beta^{\prime}}\right), 95.6\left(C^{\beta}\right), 88.0\left(C^{\alpha}\right), 77.5\left(C^{\alpha^{\prime}}\right), 30.5\left(C^{2}\right), 22.1\left(C^{3^{\prime}}\right)$, $19.4\left(C^{l^{\prime}}\right), 13.7\left(\mathrm{CH}_{3}\right)$. FT-IR-ATR: 3058, 2958, 2933, 2871, 2195, 2118, 1646, 1576, 1490, 1313, 1211 , 1019, 997, 858, 756, $685 \mathrm{~cm}^{-1}$. HRMS (ESI): $\mathrm{m} / z 288.1381\left([\mathrm{M}+\mathrm{H}]^{+}, \mathrm{C}_{20} \mathrm{H}_{18} \mathrm{NO}^{+}\right.$calcd. 288.1383).

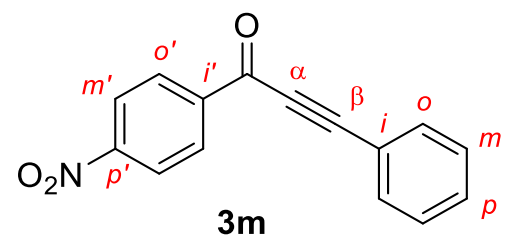

1-(4-Nitrophenyl)-3-phenylprop-2-yn-1-one (3m). The title compound was prepared according to the General Procedure 3 from 4-nitrobenzaldehyde (1m) and (2-phenylethynyl)(2,4,6trimethylphenyl)iodonium $p$-toluenosulfonate (2a). After purification by column chromatography (silica, petroleum ether:ethyl acetate/18:2 to 17:3), the product was obtained as a white solid (39 $\mathrm{mg}$, $31 \%$ yield). $\mathrm{R}_{\mathrm{f}}=0.69$ (petroleum ether:ethyl acetate/8:2). ${ }^{1} \mathrm{H}$ NMR $\left(400 \mathrm{MHz}, \mathrm{CDCl}_{3}\right) \delta 8.41-8.35(\mathrm{~m}$, $\left.4 \mathrm{H}, H^{o^{\prime}}, H^{m^{\prime}}\right), 7.74-7.70\left(\mathrm{~m}, 2 \mathrm{H}, H^{o}\right), 7.57-7.52\left(\mathrm{~m}, 1 \mathrm{H}, H^{p}\right), 7.49-7.44\left(\mathrm{~m}, 2 \mathrm{H}, H^{m}\right) .{ }^{13} \mathrm{C}$ NMR $(126$ $\left.\mathrm{MHz}, \mathrm{CDCl}_{3}\right) \delta 176.0\left(C^{C=O}\right), 151.0\left(C^{p^{\prime}}\right), 141.2\left(C^{\prime}\right), 133.4\left(C^{o}\right), 131.6\left(C^{p}\right), 130.6\left(C^{o}\right), 129.0\left(C^{m}\right)$, 124.0 $\left(C^{m}\right), 119.6\left(C^{i}\right), 95.5\left(C^{\beta}\right), 86.7\left(C^{\alpha}\right)$. The spectral data are in accordance with literature. ${ }^{43}$

\footnotetext{
${ }^{43}$ Tang, T.; Fei, X.-D.; Ge, Z.-Y.; Chen, Z.; Zhu, Y.-M.; Ji, S.-J. J. Org. Chem. 2013, 78, 3170-3175.
} 


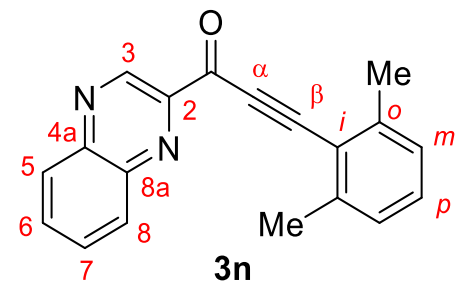

3-(2,6-Dimethylphenyl)-1-(quinoxalin-2-yl)prop-2-yn-1-one (3n). The title compound was prepared according to the General Procedure 3 from quinoxaline-2-carbaldehyde (1a) and [2-(2,6dimethylphenyl)ethynyl](2,4,6-trimethylphenyl)iodonium $p$-toluenosulfonate (2i). After purification by column chromatography (silica, petroleum ether:ethyl acetate/17:3), the product was obtained as a yellow solid (130 mg, 83\% yield). $\mathrm{R}_{\mathrm{f}}=0.63$ (petroleum ether:ethyl acetate/8:2). ${ }^{1} \mathrm{H}$ NMR $(400 \mathrm{MHz}$, $\left.\mathrm{CDCl}_{3}\right) \delta 9.62\left(\mathrm{~s}, 1 \mathrm{H}, H^{3}\right), 8.26-8.20\left(\mathrm{~m}, 2 \mathrm{H}, H^{5}, H^{8}\right), 7.91$ (dddd, $J=18.0,8.4,6.9,1.6 \mathrm{~Hz}, 2 \mathrm{H}, H^{6}$, $\left.H^{7}\right), 7.32-7.27\left(\mathrm{~m}, 1 \mathrm{H}, H^{p}\right), 7.15\left(\mathrm{~d}, J=7.7 \mathrm{~Hz}, 2 \mathrm{H}, H^{m}\right), 2.72\left(\mathrm{~s}, 6 \mathrm{H}, \mathrm{C} H_{3}\right) .{ }^{13} \mathrm{C}$ NMR $(126 \mathrm{MHz}$, $\left.\mathrm{CDCl}_{3}\right) \delta 177.6\left(C^{C=O}\right), 147.2\left(C^{2}\right), 144.0\left(C^{8 a}\right), 143.8\left(C^{o}\right), 143.5\left(C^{3}\right), 141.6\left(C^{4 a}\right), 132.7\left(C^{6}\right), 131.02$ $\left(C^{p}\right), 131.00\left(C^{7}\right), 130.7\left(C^{8}\right), 129.6\left(C^{5}\right), 127.2\left(C^{m}\right), 120.0\left(C^{i}\right), 95.6,95.5\left(C^{\alpha}, C^{\beta}\right), 21.3\left(C_{3}\right)$. FT-IRATR: $3061,2921,2855,2176,1640,1507,1457,1313,1244,1198,1023,965,763 \mathrm{~cm}^{-1}$. HRMS (ESI): $m / z$ 287.1177 $\left([\mathrm{M}+\mathrm{H}]^{+}, \mathrm{C}_{19} \mathrm{H}_{15} \mathrm{~N}_{2} \mathrm{O}^{+}\right.$calcd. 287.1179).

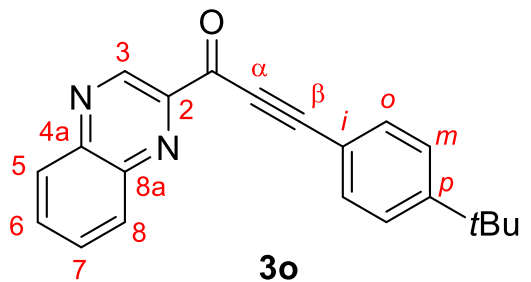

3-(4-tert-Butylphenyl)-1-(quinoxalin-2-yl)prop-2-yn-1-one (3o). The title compound was prepared according to the General Procedure 3 from quinoxaline-2-carbaldehyde (1a) and [2-(4-tertbutylphenyl)ethynyl](2,4,6-trimethylphenyl)iodonium $p$-toluenosulfonate (2j). After purification by column chromatography (silica, petroleum ether:ethyl acetate/17:3), the product was obtained as a yellow solid (132 mg, 92\% yield). $\mathrm{R}_{\mathrm{f}}=0.43$ (petroleum ether:ethyl acetate/8:2). ${ }^{1} \mathrm{H}$ NMR (400 MHz, $\left.\mathrm{CDCl}_{3}\right) \delta 9.62\left(\mathrm{~s}, 1 \mathrm{H}, H^{3}\right), 8.35-8.32\left(\mathrm{~m}, 1 \mathrm{H}, H^{8}\right), 8.23-8.20\left(\mathrm{~m}, 1 \mathrm{H}, H^{5}\right), 7.96-7.88\left(\mathrm{~m}, 2 \mathrm{H}, H^{6}\right.$, $\left.H^{7}\right), 7.75-7.71\left(\mathrm{~m}, 2 \mathrm{H}, H^{o}\right), 7.50-7.46\left(\mathrm{~m}, 2 \mathrm{H}, H^{m}\right), 1.36\left(\mathrm{~s}, J=2.1 \mathrm{~Hz}, 9 \mathrm{H}, \mathrm{C}\left(\mathrm{CH}_{3}\right)\right) .{ }^{13} \mathrm{C} \mathrm{NMR}(126$ $\left.\mathrm{MHz}, \mathrm{CDCl}_{3}\right) \delta 177.5\left(C^{C=O}\right), 155.3\left(C^{p}\right), 147.1\left(C^{2}\right), 144.0\left(C^{8 a}\right), 143.8\left(C^{3}\right), 141.6\left(C^{4 a}\right), 133.7\left(C^{o}\right)$, $132.8\left(C^{6}\right), 131.10,131.07\left(C^{7}, C^{8}\right), 129.6\left(C^{5}\right), 125.9\left(C^{m}\right), 117.0\left(C^{i}\right), 98.1\left(C^{\beta}\right), 87.7\left(C^{\alpha}\right), 35.3$ $\left(\boldsymbol{C}\left(\mathrm{CH}_{3}\right)\right)$, $31.2\left(\mathrm{C}\left(\boldsymbol{C H}_{3}\right)\right)$. FT-IR-ATR: 3065, 2962, 2924, 2869, 2195, 1641, 1570, 1496, 1322, 1201, 1108, 1025, 967, 836, $767 \mathrm{~cm}^{-1}$. HRMS (ESI): $\mathrm{m} / z 315.1490\left([\mathrm{M}+\mathrm{H}]^{+}, \mathrm{C}_{21} \mathrm{H}_{19} \mathrm{~N}_{2} \mathrm{O}^{+}\right.$calcd. 315.1492).

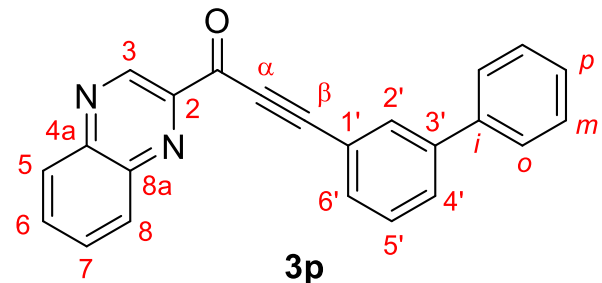

3-\{[1,1'-Biphenyl]-3-yl\}-1-(quinoxalin-2-yl)prop-2-yn-1-one (3p). The title compound was prepared according to the General Procedure 3 from quinoxaline-2-carbaldehyde (1a) and (2-\{[1,1'-biphenyl $]-3$ yl ethynyl)(2,4,6-trimethylphenyl)iodonium $p$-toluenosulfonate (2k). After purification by column chromatography (silica, petroleum ether:ethyl acetate/17:3), the product was obtained as an orange solid (135 mg, 81\% yield). $\mathrm{R}_{\mathrm{f}}=0.49$ (petroleum ether:ethyl acetate/8:2). ${ }^{1} \mathrm{H}$ NMR $\left(400 \mathrm{MHz}, \mathrm{CDCl}_{3}\right) \delta 9.63$ $\left(\mathrm{s}, 1 \mathrm{H}, H^{3}\right), 8.37-8.33\left(\mathrm{~m}, 1 \mathrm{H}, H^{8}\right), 8.24-8.20\left(\mathrm{~m}, 1 \mathrm{H}, H^{5}\right), 8.01\left(\mathrm{dd}, J=2.5,1.0 \mathrm{~Hz}, 1 \mathrm{H}, H^{2}\right), 7.97-$ 
$7.88\left(\mathrm{~m}, 2 \mathrm{H}, H^{6}, H^{7}\right), 7.79-7.73\left(\mathrm{~m}, 2 \mathrm{H}, H^{4^{\prime}}, H^{6^{\prime}}\right), 7.62\left(\mathrm{dq}, J=2.9,1.8 \mathrm{~Hz}, 2 \mathrm{H}, H^{o}\right), 7.54(\mathrm{t}, J=7.6$ $\left.\mathrm{Hz}, 1 \mathrm{H}, H^{5^{\prime}}\right), 7.52-7.47\left(\mathrm{~m}, 2 \mathrm{H}, H^{m}\right), 7.44-7.39\left(\mathrm{~m}, 1 \mathrm{H}, H^{p}\right) .{ }^{13} \mathrm{C} \mathrm{NMR}\left(126 \mathrm{MHz}, \mathrm{CDCl}_{3}\right) \delta 177.6$ $\left(C^{C=0}\right), 146.9\left(C^{2}\right), 144.1\left(C^{8 a}\right), 143.7\left(C^{3}\right), 142.0\left(C^{3}\right), 141.6\left(C^{4 a}\right), 139.7\left(C^{i}\right), 132.8\left(C^{6}\right), 132.4\left(C^{6}\right)$, $132.3\left(C^{4^{\prime}}\right), 131.12,131.10\left(C^{7}, C^{8}\right), 130.2\left(C^{4}\right), 129.6\left(C^{5}\right), 129.3\left(C^{5}\right), 129.1\left(C^{m}\right), 128.1\left(C^{p}\right), 127.2$ $\left(C^{o}\right), 120.6\left(C^{l}\right), 97.2\left(C^{\beta}\right), 87.7\left(C^{\alpha}\right)$. FT-IR-ATR: 3058, 3031, 2188, 1635, 1570, 1324, 1288, 1126, 1021, 965, 801, 752, $692 \mathrm{~cm}^{-1}$. HRMS (ESI): $\mathrm{m} / z 335.1178\left([\mathrm{M}+\mathrm{H}]^{+}, \mathrm{C}_{23} \mathrm{H}_{15} \mathrm{~N}_{2} \mathrm{O}^{+}\right.$calcd. 335.1179).

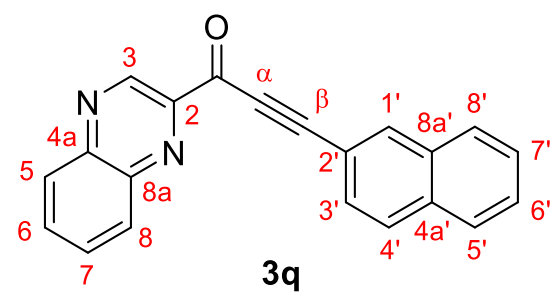

3-(Naphthalen-2-yl)-1-(quinoxalin-2-yl)prop-2-yn-1-one (3q). The title compound was prepared according to the General Procedure 3 from quinoxaline-2-carbaldehyde (1a) and [2-(naphthalen-2yl)ethynyl](2,4,6-trimethylphenyl)iodonium $p$-toluenosulfonate (2l). After purification by column chromatography (silica, petroleum ether:ethyl acetate/17:3), the product was obtained as a red solid (103 mg, 67\% yield). $\mathrm{R}_{\mathrm{f}}=0.48$ (petroleum ether:ethyl acetate/8:2). ${ }^{1} \mathrm{H} \mathrm{NMR}\left(400 \mathrm{MHz}, \mathrm{CDCl}_{3}\right) \delta 9.64$ (s, 1H, H3), 8.40 - 8.36 (m, 2H, H8, H1 '), 8.25 - 8.21 (m, 1H, H5), 7.98 - 7.86 (m, 5H, H6, H7, H4', H5', $\left.\mathrm{H} 8^{\prime}\right), 7.77$ (dd, $J=8.5,1.6 \mathrm{~Hz}, 1 \mathrm{H}, \mathrm{H} 3$ ') $7.63-7.55$ (m, 2H, H6', H7'). ${ }^{13} \mathrm{C} \mathrm{NMR}^{2}\left(126 \mathrm{MHz}, \mathrm{CDCl}_{3}\right)$ $\delta 177.5(\mathrm{CC}=\mathrm{O}), 147.0(\mathrm{C} 2), 144.0(\mathrm{C} 8 \mathrm{a}), 143.7(\mathrm{C} 3), 141.6(\mathrm{C} 4 \mathrm{a}), 135.3\left(\mathrm{C} 1{ }^{\prime}\right), 134.3$ (s), $132.8(\mathrm{C} 6)$, 132.7 (s), 131.1 (C7, C8), 129.6 (C5), 128.8 (C3'), 128.6, 128.5, 128.4, 128.0 (C4', C5', C7', C8'), 127.2 (C6'), 117.2 (C1'), 97.8 (C $\alpha$ ), 88.0 (C $\beta$ ). FT-IR-ATR: 3058, 2175, 1640, 1570, 1465, 1319, 1229 , 1130, 1028, 970, 813, $759 \mathrm{~cm}^{-1}$. HRMS (ESI): $\mathrm{m} / z$ 309.1021 ([M+H] $]^{+}, \mathrm{C}_{21} \mathrm{H}_{13} \mathrm{~N}_{2} \mathrm{O}^{+}$calcd. 309.1022).<smiles>O=C(C#Cc1cc(F)cc(F)c1)c1cnc2ccccc2n1</smiles>

3-(3,5-Difluorophenyl)-1-(quinoxalin-2-yl)prop-2-yn-1-one (3r). The title compound was prepared according to the General Procedure 3 from quinoxaline-2-carbaldehyde (1a) and [2-(3,5difluorophenyl)ethynyl](2,4,6-trimethylphenyl)iodonium $p$-toluenosulfonate (2m). After purification by column chromatography (silica, petroleum ether:ethyl acetate/17:3), the product was obtained as a yellowish solid (143 mg, 97\% yield). $\mathrm{R}_{\mathrm{f}}=0.47$ (petroleum ether:ethyl acetate/8:2). ${ }^{1} \mathrm{H}$ NMR (400 MHz, $\left.\mathrm{CDCl}_{3}\right) \delta 9.58\left(\mathrm{~s}, 1 \mathrm{H}, H^{3}\right), 8.35-8.31\left(\mathrm{~m}, 1 \mathrm{H}, H^{8}\right), 8.24-8.21\left(\mathrm{~m}, 1 \mathrm{H}, H^{5}\right), 7.99-7.89\left(\mathrm{~m}, 2 \mathrm{H}, H^{6}\right.$, $\left.H^{7}\right), 7.34-7.26\left(\mathrm{~m}, 2 \mathrm{H}, H^{o}\right), 7.00\left(\mathrm{tt}, J=8.8,2.4 \mathrm{~Hz}, 1 \mathrm{H}, H^{p}\right) .{ }^{13} \mathrm{C} \mathrm{NMR}\left(126 \mathrm{MHz}, \mathrm{CDCl}_{3}\right) \delta 177.4$ $\left(C^{C=O}\right), 162.9\left(\mathrm{dd}, J=250.9,12.9 \mathrm{~Hz}, C^{m}\right), 146.6\left(C^{2}\right), 144.3\left(C^{8 a}\right), 143.5\left(C^{3}\right), 141.6\left(C^{4 a}\right), 133.1\left(C^{6}\right)$, $131.3\left(C^{7}\right), 131.1\left(C^{8}\right), 129.7\left(C^{5}\right), 122.8\left(\mathrm{t}, J=11.6 \mathrm{~Hz}, C^{i}\right), 116.5\left(\mathrm{dd}, J=20.5,6.9 \mathrm{~Hz}, C^{o}\right), 107.5(\mathrm{t}$, $\left.J=25.2 \mathrm{~Hz}, C^{p}\right), 93.2\left(\mathrm{t}, J=4.0 \mathrm{~Hz}, C^{\beta}\right), 88.1\left(C^{\alpha}\right) .{ }^{19} \mathrm{~F} \mathrm{NMR}\left(376 \mathrm{MHz}, \mathrm{CDCl}_{3}\right) \delta-108.0--108.1(\mathrm{~m})$. FT-IR-ATR: 3078, 3050, 3035, 2204, 1653, 1592, 1430, 1301, 1290, 1122, 1050, 927, 863, 768, 671 $\mathrm{cm}^{-1}$. HRMS (ESI): $\mathrm{m} / z 295.0677\left([\mathrm{M}+\mathrm{H}]^{+}, \mathrm{C}_{19} \mathrm{H}_{9} \mathrm{~F}_{2} \mathrm{~N}_{2} \mathrm{O}^{+}\right.$calcd. 295.0678). 


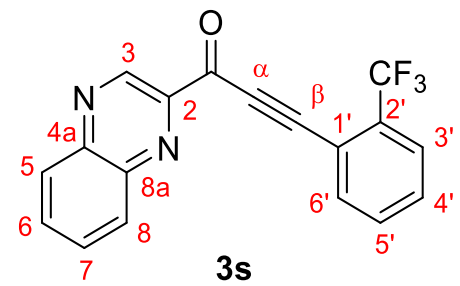

1-(Quinoxalin-2-yl)-3-[2-(trifluoromethyl)phenyl]prop-2-yn-1-one (3s). The title compound was prepared according to the General Procedure 3 from quinoxaline-2-carbaldehyde (1a) and $\{2-[2-$ (trifluoromethyl)phenyl]ethynyl\}(2,4,6-trimethylphenyl)iodonium $\quad p$-toluenosulfonate (2n). After purification by column chromatography (silica, petroleum ether:ethyl acetate/17:3), the product was obtained as a yellow solid (120 mg, 74\% yield). $R_{\mathrm{f}}=0.37$ (petroleum ether:ethyl acetate/8:2). ${ }^{1} \mathrm{H}$ NMR $\left(400 \mathrm{MHz}, \mathrm{CDCl}_{3}\right) \delta 9.60\left(\mathrm{~s}, 1 \mathrm{H}, H^{3}\right), 8.35-8.31\left(\mathrm{~m}, 1 \mathrm{H}, H^{8}\right), 8.23-8.20\left(\mathrm{~m}, 1 \mathrm{H}, H^{5}\right), 7.98-7.88(\mathrm{~m}$, $\left.3 \mathrm{H}, H^{6}, H^{7}, H^{6^{\prime}}\right), 7.83-7.78\left(\mathrm{~m}, 1 \mathrm{H}, H^{3^{\prime}}\right), 7.69-7.60\left(\mathrm{~m}, 2 \mathrm{H}, H^{4^{\prime}}, H^{5^{\prime}}\right) .{ }^{13} \mathrm{C} \mathrm{NMR}\left(126 \mathrm{MHz}, \mathrm{CDCl}_{3}\right) \delta$ $177.4\left(C^{C=O}\right), 146.8\left(C^{2}\right), 144.1\left(C^{8 a}\right), 143.5\left(C^{3}\right), 141.7\left(C^{4 a}\right), 136.2\left(C^{6}\right), 133.2\left(\mathrm{q}, J=31.3 \mathrm{~Hz}, C^{2 \prime}\right)$, $133.0\left(C^{6}\right), 131.9\left(C^{5^{\prime}}\right), 131.18\left(C^{7}\right), 131.16\left(C^{8}\right), 131.0\left(C^{4^{\prime}}\right), 129.5\left(C^{5}\right), 126.5\left(\mathrm{q}, J=5.0 \mathrm{~Hz}, C^{3^{\prime}}\right)$, $123.3\left(\mathrm{q}, J=273.8 \mathrm{~Hz}, C \mathrm{~F}_{3}\right), 118.3\left(\mathrm{~d}, J=2.1 \mathrm{~Hz}, C^{l^{\prime}}\right), 91.5\left(C^{\beta}\right), 91.3\left(C^{\alpha}\right) .{ }^{19} \mathrm{~F}$ NMR $(376 \mathrm{MHz}$, $\left.\mathrm{CDCl}_{3}\right) \delta$-61.6 (s). FT-IR-ATR: 3058, 3011, 2196, 1648, 1570, 1448, 1312, 1121, 1060, 963, 769, 665 $\mathrm{cm}^{-1}$. HRMS (ESI): $\mathrm{m} / z 327.0738\left([\mathrm{M}+\mathrm{H}]^{+}, \mathrm{C}_{18} \mathrm{H}_{10} \mathrm{~F}_{3} \mathrm{~N}_{2} \mathrm{O}^{+}\right.$calcd. 327.0740).<smiles>O=C(C#Cc1ccc(Cl)c(Cl)c1)c1cnc2ccccc2n1</smiles>

3-(3,4-Dichlorophenyl)-1-(quinoxalin-2-yl)prop-2-yn-1-one (3t). The title compound was prepared according to the General Procedure 3 from quinoxaline-2-carbaldehyde (1a) and [2-(3,4dichlorophenyl)ethynyl](2,4,6-trimethylphenyl)iodonium $p$-toluenosulfonate (2o). After purification by column chromatography (silica, petroleum ether:ethyl acetate/18:2 to 14:6), the product was obtained as a yellow solid (130 mg, 80\% yield). $\mathrm{R}_{\mathrm{f}}=0.55$ (petroleum ether:ethyl acetate/8:2). ${ }^{1} \mathrm{H}$ NMR (400 $\left.\mathrm{MHz}, \mathrm{CDCl}_{3}\right) \delta 9.59\left(\mathrm{~s}, 1 \mathrm{H}, H^{3}\right), 8.36-8.31\left(\mathrm{~m}, 1 \mathrm{H}, H^{8}\right), 8.24-8.20\left(\mathrm{~m}, 1 \mathrm{H}, H^{5}\right), 7.99-7.89(\mathrm{~m}, 2 \mathrm{H}$, $\left.H^{6}, H^{7}\right), 7.87\left(\mathrm{~d}, J=1.8 \mathrm{~Hz}, 1 \mathrm{H}, H^{2}\right), 7.61\left(\mathrm{dd}, J=8.3,1.9 \mathrm{~Hz}, 1 \mathrm{H}, H^{6^{\prime}}\right), 7.55\left(\mathrm{~d}, J=8.4 \mathrm{~Hz}, 1 \mathrm{H}, H^{5^{\prime}}\right)$. ${ }^{13} \mathrm{C}$ NMR $\left(126 \mathrm{MHz}, \mathrm{CDCl}_{3}\right) \delta 177.3\left(C^{C=O}\right), 146.6\left(C^{2}\right), 144.1\left(C^{8 a}\right), 143.4\left(\mathrm{~d}, J=19.6 \mathrm{~Hz}, C^{3}\right), 141.4$ $\left(C^{4 a}\right), 136.1\left(C^{3^{\prime}}\right), 134.9\left(C^{2^{\prime}}\right), 133.3\left(C^{4^{\prime}}\right), 132.9\left(C^{6}\right), 132.4\left(C^{6^{\prime}}\right), 131.1\left(C^{5^{\prime}}\right), 130.94,130.90\left(C^{7}\right.$, $\left.C^{8}\right), 129.6\left(C^{5}\right), 112.0\left(C^{1}\right), 93.6\left(C^{\beta}\right), 88.5\left(C^{\alpha}\right)$. FT-IR-ATR: 3061, 2199, 1646, 1465, 1327, 1128, $1029,969,853,766 \mathrm{~cm}^{-1}$. HRMS (ESI): $\mathrm{m} / z 327.0086\left([\mathrm{M}+\mathrm{H}]^{+}, \mathrm{C}_{17} \mathrm{H}_{9} \mathrm{Cl}_{2} \mathrm{~N}_{2} \mathrm{O}^{+}\right.$calcd. 327.0086).<smiles>N#Cc1ccc(C#CC(=O)c2cnc3ccccc3n2)cc1</smiles>

4-[3-Oxo-3-(quinoxalin-2-yl)prop-1-yn-1-yl]benzonitrile (3u). The title compound was prepared according to the General Procedure 3 from quinoxaline-2-carbaldehyde (1a) and [2-(4cyanophenyl)ethynyl](2,4,6-trimethylphenyl)iodonium $p$-toluenosulfonate (2p). After purification by column chromatography (silica, petroleum ether:ethyl acetate/16:4 to 15:5), the product was obtained as a yellow solid ( $84 \mathrm{mg}, 59 \%$ yield). $\mathrm{R}_{\mathrm{f}}=0.33$ (petroleum ether:ethyl acetate/8:2). ${ }^{1} \mathrm{H}$ NMR (400 MHz, $\left.\mathrm{CDCl}_{3}\right) \delta 9.59\left(\mathrm{~s}, 1 \mathrm{H}, H^{3}\right), 8.34-8.30\left(\mathrm{~m}, 1 \mathrm{H}, H^{8}\right), 8.25-8.22\left(\mathrm{~m}, 1 \mathrm{H}, H^{5}\right), 7.94(\mathrm{dddd}, J=18.8,8.4$, 
6.9, $\left.1.6 \mathrm{~Hz}, 2 \mathrm{H}, H^{6}, H^{7}\right), 7.89-7.85\left(\mathrm{~m}, 2 \mathrm{H}, H^{o}\right), 7.78-7.74\left(\mathrm{~m}, 2 \mathrm{H}, H^{m}\right) .{ }^{13} \mathrm{C} \mathrm{NMR}\left(126 \mathrm{MHz}, \mathrm{CDCl}_{3}\right)$ $\delta 177.5\left(C^{C=O}\right), 146.6\left(C^{2}\right), 144.3\left(C^{8 a}\right), 143.5\left(\mathrm{~d}, J=13.6 \mathrm{~Hz}, C^{3}\right), 141.6\left(C^{4 a}\right), 133.8\left(C^{o}\right), 133.2\left(C^{6}\right)$, $132.4\left(C^{m}\right), 131.3\left(C^{7}\right), 131.0\left(C^{8}\right), 129.7\left(C^{5}\right), 125.0\left(C^{i}\right), 118.0(\boldsymbol{C N}), 114.5\left(C^{p}\right), 93.4\left(C^{\beta}\right), 89.9\left(C^{\alpha}\right)$. FT-IR-ATR: 3064, 2202, 1653, 1507, 1457, 1319, 1204, 1128, 1026, 962, 842, $768 \mathrm{~cm}^{-1}$. HRMS (ESI): $m / z 284.0818\left([\mathrm{M}+\mathrm{H}]^{+}, \mathrm{C}_{18} \mathrm{H}_{10} \mathrm{~N}_{3} \mathrm{O}^{+}\right.$calcd. 284.0818).

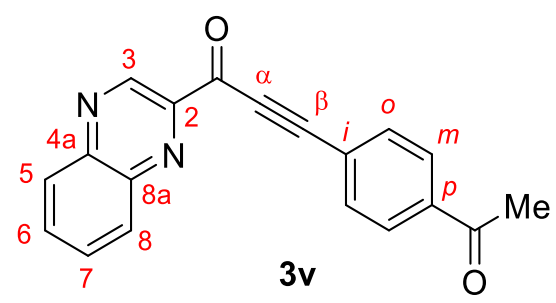

3-(4-Acetylphenyl)-1-(quinoxalin-2-yl)prop-2-yn-1-one (3v). The title compound was prepared according to the General Procedure 3 from quinoxaline-2-carbaldehyde (1a) and [2-(4acetylphenyl)ethynyl](2,4,6-trimethylphenyl)iodonium $p$-toluenosulfonate (2q). After purification by column chromatography (silica, petroleum ether:ethyl acetate/8:2), the product was obtained as a red solid (129 mg, 86\% yield). $\mathrm{R}_{\mathrm{f}}=0.23$ (petroleum ether:ethyl acetate/8:2). ${ }^{1} \mathrm{H}$ NMR $\left(400 \mathrm{MHz}, \mathrm{CDCl}_{3}\right) \delta$ $9.60\left(\mathrm{~s}, 1 \mathrm{H}, H^{3}\right), 8.32\left(\mathrm{dd}, J=8.4,1.2 \mathrm{~Hz}, 1 \mathrm{H}, H^{8}\right), 8.21\left(\mathrm{dd}, J=8.3,1.1 \mathrm{~Hz}, 1 \mathrm{H}, H^{5}\right), 8.02(\mathrm{~d}, J=8.4$ $\left.\mathrm{Hz}, 2 \mathrm{H}, H^{m}\right), 7.92$ (dddd, $\left.J=20.4,8.3,6.9,1.5 \mathrm{~Hz}, 2 \mathrm{H}, H^{6}, H^{7}\right), 7.86\left(\mathrm{~d}, J=8.4 \mathrm{~Hz}, 2 \mathrm{H}, H^{o}\right), 2.66$ (s, $\left.3 \mathrm{H}, \mathrm{CH}_{3}\right) .{ }^{13} \mathrm{C}$ NMR $\left(126 \mathrm{MHz}, \mathrm{CDCl}_{3}\right) \delta 197.2\left(\mathrm{O}=C-\mathrm{CH}_{3}\right), 177.6\left(C^{C=O}\right), 146.7\left(C^{2}\right), 144.2\left(C^{8 a}\right), 143$. $6\left(\mathrm{~d}, J=15.3 \mathrm{~Hz}, C^{3}\right), 141.6\left(C^{4 a}\right), 138.5\left(C^{p}\right), 133.7\left(C^{o}\right), 133.0\left(C^{6}\right), 131.2\left(C^{7}\right), 131.1\left(C^{8}\right), 129.7\left(C^{5}\right)$, $128.5\left(C^{m}\right), 124.7\left(C^{i}\right), 95.1\left(C^{\beta}\right), 89.3\left(C^{\alpha}\right), 26.9\left(C_{3}\right)$. FT-IR-ATR: 3061, 2195, 1690, 1636, 1507, $1465,1319,1262,1126,1030,962,825,778 \mathrm{~cm}^{-1}$. HRMS (ESI): $\mathrm{m} / z 301.0971\left([\mathrm{M}+\mathrm{H}]^{+}, \mathrm{C}_{19} \mathrm{H}_{13} \mathrm{~N}_{2} \mathrm{O}_{2}{ }^{+}\right.$ calcd. 301.0972).

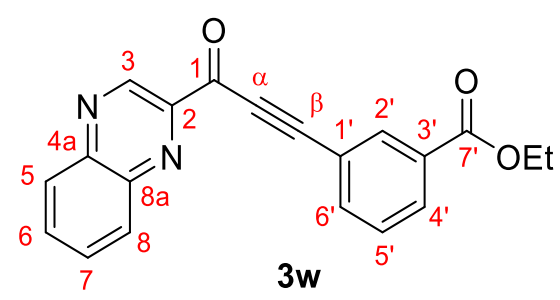

Ethyl 3-[3-oxo-3-(quinoxalin-2-yl)prop-1-yn-1-yl]benzoate (3w). The title compound was prepared according to the General Procedure 3 from quinoxaline-2-carbaldehyde (1a) and $\{2-[3-$ (ethoxycarbonyl)phenyl]ethynyl $\}$ (2,4,6-trimethylphenyl)iodonium $\quad$-toluenosulfonate (2r). After purification by column chromatography (silica, petroleum ether:ethyl acetate/17:3), the product was obtained as a yellow solid (124 mg, 75\% yield). $\mathrm{R}_{\mathrm{f}}=0.38$ (petroleum ether:ethyl acetate/8:2). ${ }^{1} \mathrm{H}$ NMR $\left(400 \mathrm{MHz}, \mathrm{CDCl}_{3}\right) \delta 9.59\left(\mathrm{~s}, 1 \mathrm{H}, H^{3}\right), 8.44\left(\mathrm{t}, J=1.5 \mathrm{~Hz}, 1 \mathrm{H}, H^{2}\right), 8.33\left(\mathrm{dd}, J=7.9,1.7 \mathrm{~Hz}, 1 \mathrm{H}, H^{8}\right)$, $8.20-8.16\left(\mathrm{~m}, 2 \mathrm{H}, H^{5}, H^{4^{\prime}}\right), 7.96-7.90\left(\mathrm{~m}, 2 \mathrm{H}, H^{6}, H^{7}\right), 7.89\left(\mathrm{ddd}, J=8.3,6.9,1.6 \mathrm{~Hz}, 1 \mathrm{H}, H^{6^{\prime}}\right), 7.54$ $\left(\mathrm{t}, J=7.8 \mathrm{~Hz}, 1 \mathrm{H}, H^{5^{\prime}}\right), 4.43\left(\mathrm{q}, J=7.1 \mathrm{~Hz}, 2 \mathrm{H}, \mathrm{CH}_{2}\right), 1.42\left(\mathrm{t}, J=7.1 \mathrm{~Hz}, 3 \mathrm{H}, \mathrm{CH}_{3}\right) .{ }^{13} \mathrm{C} \mathrm{NMR}(126$ $\left.\mathrm{MHz}, \mathrm{CDCl}_{3}\right) \delta 177.6\left(C^{1}\right), 165.4\left(C^{7^{\prime}}\right), 146.8\left(C^{2}\right), 144.2\left(C^{8 a}\right), 143.6\left(C^{3}\right), 141.6\left(C^{4 a}\right), 137.4\left(C^{6^{\prime}}\right)$, $134.7\left(C^{2^{\prime}}\right), 132.9\left(C^{6}\right), 132.2\left(C^{4^{\prime}}\right), 131.4\left(C^{3^{\prime}}\right), 131.2\left(C^{7}\right), 131.1\left(C^{8}\right), 129.6\left(C^{5}\right), 129.0\left(C^{5^{\prime}}\right), 120.6$ $\left(C^{l^{\prime}}\right), 95.6\left(C^{\beta}\right), 87.9\left(C^{\alpha}\right), 61.6\left(C_{2}\right), 14.4\left(C \mathrm{CH}_{3}\right)$. FT-IR-ATR: 3064, 2925, 2195, 1714, 1653, 1465 , 1318, 1205, 1103, 1031, 971, 751, $680 \mathrm{~cm}^{-1}$. HRMS (ESI): $\mathrm{m} / z 331.1076\left([\mathrm{M}+\mathrm{H}]^{+}, \mathrm{C}_{20} \mathrm{H}_{15} \mathrm{~N}_{2} \mathrm{O}_{3}{ }^{+}\right.$calcd. 331.1077). 


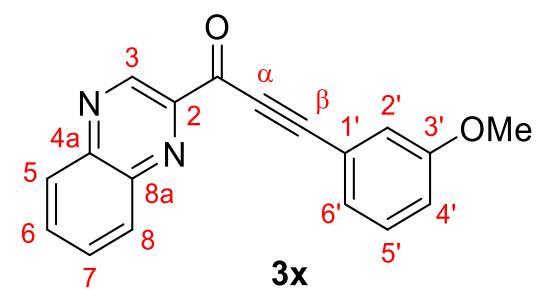

3-(3-Methoxyphenyl)-1-(quinoxalin-2-yl)prop-2-yn-1-one (3x). The title compound was prepared according to the General Procedure 3 from quinoxaline-2-carbaldehyde (1a) and [2-(3methoxyphenyl)ethynyl](2,4,6-trimethylphenyl)iodonium $p$-toluenosulfonate (2s). After purification by column chromatography (silica, petroleum ether:ethyl acetate/17:3), the product was obtained as a red solid (99 mg, 69\% yield). $\mathrm{R}_{\mathrm{f}}=0.34$ (petroleum ether:ethyl acetate/8:2). ${ }^{1} \mathrm{H}$ NMR $\left(400 \mathrm{MHz}, \mathrm{CDCl}_{3}\right) \delta$ $9.59\left(\mathrm{~s}, 1 \mathrm{H}, H^{3}\right), 8.31\left(\mathrm{dd}, J=8.4,1.2 \mathrm{~Hz}, 1 \mathrm{H}, H^{8}\right), 8.21-8.17\left(\mathrm{~m}, 1 \mathrm{H}, H^{5}\right), 7.90(\mathrm{dtd}, J=15.0,7.0,1.4$ $\left.\mathrm{Hz}, 2 \mathrm{H}, H^{6}, H^{7}\right), 7.40-7.32\left(\mathrm{~m}, 2 \mathrm{H}, H^{5^{\prime}}, H^{6^{\prime}}\right), 7.28-7.25\left(\mathrm{~m}, 1 \mathrm{H}, H^{2}\right), 7.06(\mathrm{ddd}, J=7.9,2.5,1.3 \mathrm{~Hz}$, $\left.1 \mathrm{H}, H^{4^{\prime}}\right), 3.85\left(\mathrm{~s}, 3 \mathrm{H}, \mathrm{CH}_{3}\right) .{ }^{13} \mathrm{C} \mathrm{NMR}\left(126 \mathrm{MHz}, \mathrm{CDCl}_{3}\right) \delta 177.5\left(C^{C=O}\right), 159.5\left(C^{3^{\prime}}\right), 146.8\left(C^{2}\right), 144.0$ $\left(C^{8 a}\right), 143.6\left(\mathrm{~d}, J=15.0 \mathrm{~Hz}, C^{3}\right), 141.5\left(C^{4 a}\right), 132.7\left(C^{6}\right), 131.01\left(C^{7}\right), 130.98\left(C^{8}\right), 129.8\left(C^{6^{\prime}}\right), 129.5$ $\left(C^{5}\right), 126.2\left(C^{5^{\prime}}\right), 120.9\left(C^{l^{\prime}}\right), 118.1\left(C^{4^{\prime}}\right), 118.0\left(C^{2^{\prime}}\right), 97.1\left(C^{\beta}\right), 87.2\left(C^{\alpha}\right), 55.5\left(C_{3}\right)$. FT-IR-ATR: 3067, 2925, 2855, 2186, 1637, 1576, 1484, 1224, 1169, 1046, 970, 887, 769, $683 \mathrm{~cm}^{-1}$. HRMS (ESI): $m / z 289.0970\left([\mathrm{M}+\mathrm{H}]^{+}, \mathrm{C}_{18} \mathrm{H}_{13} \mathrm{~N}_{2} \mathrm{O}_{2}{ }^{+}\right.$calcd. 289.0972).

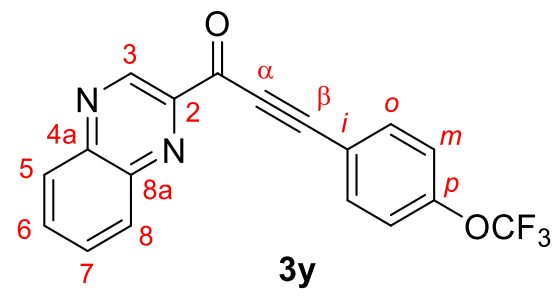

1-(Quinoxalin-2-yl)-3-[4-(trifluoromethoxy)phenyl]prop-2-yn-1-one (3y). The title compound was prepared according to the General Procedure 3 from quinoxaline-2-carbaldehyde (1a) and $\{2-[4-$ (trifluoromethoxy)phenyl]ethynyl\}(2,4,6-trimethylphenyl)iodonium $p$-toluenosulfonate (2t). After purification by column chromatography (silica, petroleum ether:ethyl acetate/18:2 to 17:3), the product was obtained as a yellow solid $(139 \mathrm{mg}, 81 \%$ yield). This product was also synthesized in a $6.0 \mathrm{mmol}$ scale in $80 \%$ yield $(1.64 \mathrm{~g}) . \mathrm{R}_{\mathrm{f}}=0.46$ (petroleum ether:ethyl acetate/8:2). ${ }^{1} \mathrm{H}$ NMR $\left(400 \mathrm{MHz}, \mathrm{CDCl}_{3}\right)$ $\delta 9.60\left(\mathrm{~s}, 1 \mathrm{H}, H^{3}\right), 8.34-8.31\left(\mathrm{~m}, 1 \mathrm{H}, H^{8}\right), 8.24-8.21\left(\mathrm{~m}, 1 \mathrm{H}, H^{5}\right), 7.98-7.89\left(\mathrm{~m}, 2 \mathrm{H}, H^{6}, H^{7}\right), 7.85-$ $7.81\left(\mathrm{~m}, 2 \mathrm{H}, H^{o}\right), 7.34-7.28\left(\mathrm{~m}, 2 \mathrm{H}, H^{m}\right) .{ }^{13} \mathrm{C} \mathrm{NMR}\left(126 \mathrm{MHz}, \mathrm{CDCl}_{3}\right) \delta 177.5\left(C^{C=O}\right), 151.2(\mathrm{~d}, J=$ $\left.1.7 \mathrm{~Hz}, C^{p}\right), 146.8\left(C^{2}\right), 144.1\left(C^{8 a}\right), 143.6\left(\mathrm{~d}, J=20.0 \mathrm{~Hz}, C^{3}\right), 141.6\left(C^{4 a}\right), 135.4\left(C^{o}\right), 132.9\left(C^{6}\right), 131.2$ $\left(C^{7}\right), 131.0\left(C^{8}\right), 129.6\left(C^{5}\right), 121.0\left(C^{m}\right), 120.4\left(\mathrm{q}, J=258.9 \mathrm{~Hz}, C \mathrm{~F}_{3}\right), 118.7\left(C^{i}\right), 95.2\left(C^{\alpha}\right), 88.1\left(C^{\beta}\right)$. ${ }^{19} \mathrm{~F} \mathrm{NMR}\left(376 \mathrm{MHz}, \mathrm{CDCl}_{3}\right) \delta$-57.7 (s). FT-IR-ATR: 3106, 3067, 2195, 1642, 1506, 1493, 1369, 1251, 1156, 1026, 966, 848, $769 \mathrm{~cm}^{-1}$. HRMS (ESI): $\mathrm{m} / z 343.0689\left([\mathrm{M}+\mathrm{H}]^{+}, \mathrm{C}_{18} \mathrm{H}_{10} \mathrm{~F}_{3} \mathrm{~N}_{2} \mathrm{O}_{2}{ }^{+}\right.$calcd. 343.0689).

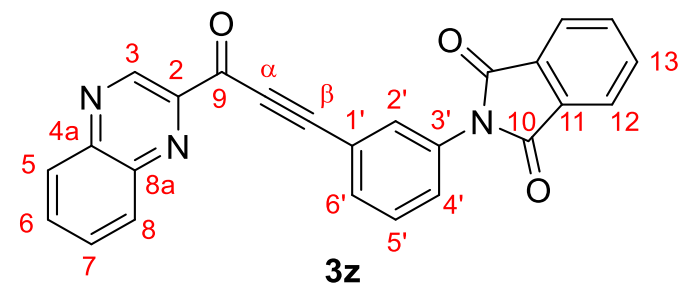

2-\{3-[3-Oxo-3-(quinoxalin-2-yl)prop-1-yn-1-yl]phenyl\}-2,3-dihydro-1H-isoindole-1,3-dione (3z). The title compound was prepared according to the General Procedure 3 from quinoxaline-2carbaldehyde (1a) and $\{2$-[3-(1,3-dioxo-2,3-dihydro-1H-isoindol-2-yl)phenyl]ethynyl $\}(2,4,6-$ trimethylphenyl)iodonium $p$-toluenosulfonate $(\mathbf{2 u})$. After purification by column chromatography 
(silica, dichloromethane:ethyl acetate/20:0 to 19:1), the product was obtained as an ivory solid (109 $\mathrm{mg}$, $54 \%$ yield). $\mathrm{R}_{\mathrm{f}}=0.40$ (petroleum ether:ethyl acetate/1:1). ${ }^{1} \mathrm{H}$ NMR $\left(400 \mathrm{MHz}, \mathrm{CDCl}_{3}\right) \delta 9.61(\mathrm{~s}, 1 \mathrm{H}$, $\left.H^{3}\right), 8.37-8.33\left(\mathrm{~m}, 1 \mathrm{H}, H^{8}\right), 8.21\left(\mathrm{dd}, J=8.3,1.4 \mathrm{~Hz}, 1 \mathrm{H}, H^{5}\right), 8.03-7.98\left(\mathrm{~m}, 2 \mathrm{H}, H^{12}\right), 7.97-7.87$ $\left(\mathrm{m}, 3 \mathrm{H}, H^{6}, H^{7}, H^{2}\right), 7.86-7.80\left(\mathrm{~m}, 3 \mathrm{H}, H^{13}, H^{6}\right), 7.68-7.64\left(\mathrm{~m}, 1 \mathrm{H}, H^{4^{\prime}}\right), 7.61(\mathrm{t}, J=7.6 \mathrm{~Hz}, 1 \mathrm{H}$, $\left.H^{5^{\prime}}\right) .{ }^{13} \mathrm{C}$ NMR $\left(126 \mathrm{MHz}, \mathrm{CDCl}_{3}\right) \delta 177.6\left(C^{9}\right), 166.9\left(C^{10}\right), 146.8\left(C^{2}\right), 144.1\left(C^{8 a}\right), 143.6\left(C^{3}\right), 141.6$ $\left(C^{4 a}\right), 134.8\left(C^{13}\right), 133.0\left(C^{6}\right), 132.9\left(C^{6}\right), 132.4\left(C^{3^{\prime}}\right), 131.7\left(C^{11}\right), 131.20,131.17,131.14\left(C^{7}, C^{8}, C^{2}\right)$, $129.7\left(C^{5^{\prime}}\right), 129.6\left(C^{5}\right), 129.3\left(C^{4}\right), 124.1\left(C^{13}\right), 121.3\left(C^{1}\right), 95.6\left(C^{\beta}\right), 88.1\left(C^{\alpha}\right)$. FT-IR-ATR: 3036, 2199, 1714, 1653, 1378, 1324, 1105, 1037, 918, 870, 713, $676 \mathrm{~cm}^{-1}$. HRMS (ESI): $\mathrm{m} / z$ 404.1029 $\left([\mathrm{M}+\mathrm{H}]^{+}, \mathrm{C}_{25} \mathrm{H}_{14} \mathrm{~N}_{3} \mathrm{O}_{3}{ }^{+}\right.$calcd. 404.1030).

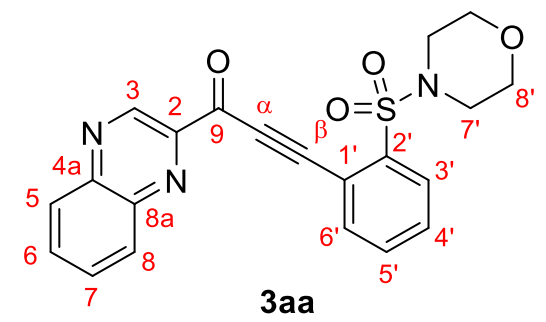

3-[2-(Morpholine-4-sulfonyl)phenyl]-1-(quinoxalin-2-yl)prop-2-yn-1-one $\quad$ (3aa). The title compound was prepared according to the General Procedure 3 from quinoxaline-2-carbaldehyde (1a) and $\quad\{2-[2-($ morpholine-4-sulfonyl)phenyl]ethynyl $\}$ (2,4,6-trimethylphenyl)iodonium $\quad p$ toluenosulfonate $(\mathbf{2 v})$. After purification by column chromatography (silica, petroleum ether:ethyl acetate/3:1 to $2: 2)$, the product was obtained as an orange solid (122 mg, 60\% yield). $R_{\mathrm{f}}=0.26$ (petroleum ether:ethyl acetate/1:1). ${ }^{1} \mathrm{H}$ NMR $\left(400 \mathrm{MHz}, \mathrm{CDCl}_{3}\right) \delta 9.59\left(\mathrm{~s}, 1 \mathrm{H}, H^{3}\right), 8.32-8.28(\mathrm{~m}, 1 \mathrm{H}$, $\left.H^{8}\right), 8.19\left(\mathrm{~d}, J=8.2 \mathrm{~Hz}, 1 \mathrm{H}, H^{5}\right), 8.04\left(\mathrm{dd}, J=7.5,1.5 \mathrm{~Hz}, 1 \mathrm{H}, \mathrm{H}, H^{3^{\prime}}\right), 7.99(\mathrm{dd}, J=7.3,1.5 \mathrm{~Hz}, 1 \mathrm{H}$, $\left.H^{6^{\prime}}\right), 7.96-7.86\left(\mathrm{~m}, 2 \mathrm{H}, H^{6}, H^{7}\right), 7.66\left(\mathrm{pd}, J=7.5,1.5 \mathrm{~Hz}, 2 \mathrm{H}, H^{4^{\prime}}, H^{5^{\prime}}\right), 3.72-3.69\left(\mathrm{~m}, 4 \mathrm{H}, H^{8^{\prime}}\right), 3.37$ $-3.33\left(\mathrm{~m}, 4 \mathrm{H}, H^{7^{\prime}}\right) .{ }^{13} \mathrm{C}$ NMR $\left(126 \mathrm{MHz}, \mathrm{CDCl}_{3}\right) \delta 177.3\left(C^{C=O}\right), 146.7\left(C^{2}\right), 144.2\left(C^{8 a}\right), 143.6\left(C^{3}\right)$, 141.6 $\left(C^{4 a}\right), 139.5\left(C^{2^{\prime}}\right), 137.2\left(C^{6^{\prime}}\right), 133.1\left(C^{6}\right), 132.7\left(C^{4 a}\right), 131.3\left(C^{7}\right), 131.1\left(C^{5^{\prime}}\right), 130.8\left(C^{8}\right), 130.6$ $\left(C^{3^{\prime}}\right), 129.7\left(C^{5}\right), 119.1\left(C^{l^{\prime}}\right), 93.2\left(C^{\beta}\right), 92.3\left(C^{\alpha}\right), 66.44\left(C^{8^{\prime}}\right), 46.14\left(C^{\gamma^{\prime}}\right)$. FT-IR-ATR: 3065, 2924, 2847, 2198, 1653, 1569, 1473, 1357, 1272, 1176, 1023, 949, 802, 736, $611 \mathrm{~cm}^{-1}$. HRMS (ESI): $\mathrm{m} / \mathrm{z}$ $408.1012\left([\mathrm{M}+\mathrm{H}]^{+}, \mathrm{C}_{21} \mathrm{H}_{18} \mathrm{~N}_{3} \mathrm{O}_{4} \mathrm{~S}^{+}\right.$calcd. 408.1013).

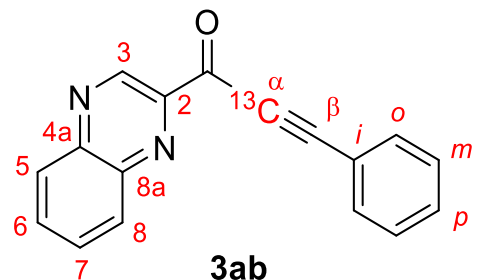

3-Phenyl-1-(quinoxalin-2-yl)prop-2-yn-1-one (3ab). The title compound was prepared according to the General Procedure 3 from quinoxaline-2-carbaldehyde (1a) and [2-phenyl( $\left.1-{ }^{13} C\right)$ ethynyl] $(2,4,6-$ trimethylphenyl) iodonium $p$-toluenosulfonate $(\mathbf{2 w})$. After purification by column chromatography (silica, petroleum ether:ethyl acetate/9:1 to 8:2), the product was obtained as a yellow solid (102 mg, $79 \%$ yield). $\mathrm{R}_{\mathrm{f}}=0.46$ (petroleum ether:ethyl acetate/8:2). ${ }^{1} \mathrm{H} \mathrm{NMR}\left(500 \mathrm{MHz}, \mathrm{CDCl}_{3}\right) \delta 9.52(\mathrm{~s}, 1 \mathrm{H}$, $\left.H^{3}\right), 8.26-8.22\left(\mathrm{~m}, 1 \mathrm{H}, H^{8}\right), 8.14-8.09\left(\mathrm{~m}, 1 \mathrm{H}, H^{5}\right), 7.87-7.78\left(\mathrm{~m}, 2 \mathrm{H}, H^{6}, H^{7}\right), 7.70(\mathrm{dt}, \mathrm{J}=8.5,1.8$ $\left.\mathrm{Hz}, 2 \mathrm{H}, H^{o}\right), 7.47-7.41\left(\mathrm{~m}, 1 \mathrm{H}, H^{p}\right), 7.40-7.33\left(\mathrm{~m}, 2 \mathrm{H}, H^{m}\right) .{ }^{13} \mathrm{C} \mathrm{NMR}\left(126 \mathrm{MHz}, \mathrm{CDCl}_{3}\right) \delta 177.6(\mathrm{~d}$, $\left.J=97.2 \mathrm{~Hz}, C^{C=O}\right), 146.9\left(\mathrm{~d}, J=19.1 \mathrm{~Hz}, C^{2}\right), 144.0\left(C^{8 a}\right), 143.7\left(\mathrm{~d}, J=21.6 \mathrm{~Hz}, C^{3}\right), 141.6\left(C^{4 a}\right), 133.7$ $\left(\mathrm{d}, J=2.5 \mathrm{~Hz}, C^{o}\right), 132.8\left(C^{6}\right), 131.4\left(C^{p}\right), 131.10\left(C^{7}\right), 131.05\left(C^{8}\right), 129.6\left(C^{5}\right), 128.8\left(C^{m}\right), 120.0(\mathrm{~d}, J$ $\left.=11.7 \mathrm{~Hz}, C^{i}\right), 97.3\left(\mathrm{~d}, J=177.4 \mathrm{~Hz}, C^{\beta}\right), 87.6\left(C^{\alpha} ;{ }^{13} \mathrm{C}\right.$ label $) .{ }^{13} \mathrm{C}$ NMR spectra without NOE shows that the compound contains $99 \%{ }^{13} \mathrm{C}$ at the $\alpha$-position. FT-IR-ATR: 3053, 3036, 2195, 1638, 1490, 
1326, 1202, 1033, 965, 766, $687 \mathrm{~cm}^{-1}$. HRMS (ESI): $\mathrm{m} / \mathrm{z} 260.0898\left([\mathrm{M}+\mathrm{H}]^{+}, \mathrm{C}_{16}{ }^{13} \mathrm{CH}_{11} \mathrm{~N}_{2} \mathrm{O}^{+}\right.$calcd 260.0899).

\section{Kinetic Investigations}

\subsection{Time-Course Experiment (Figure 1)}

In a nitrogen-atmosphere glovebox, an NMR tube was charged with aldehyde 1a (5.5 mg, 0.035 mmol), alkynyliodonium salt $\mathbf{2 a}(21.8 \mathrm{mg}, 0.042 \mathrm{mmol})$, and catalyst precursor NHC-1 (1.3 mg, 0.0035 mmol). Next, $d_{8}$-toluene ( $700 \mu \mathrm{L}$ ) was added, followed by 1 -fluorododecane (internal standard; $8.1 \mu \mathrm{L}$, $0.035 \mathrm{mmol}$ ). The NMR tube was capped, removed from the glovebox, and inserted into NMR magnet with the probe temperature set to $-40{ }^{\circ} \mathrm{C}$. After $10 \mathrm{~min}$, the time $=0$ spectra was taken. Then, the NMR tube was removed from the magnet and neat TMEDA $(7.9 \mu \mathrm{L}, 0.053 \mathrm{mmol})$ was quickly added via syringe to initiate the reaction. The NMR tube was shaken to ensure complete mixing of the solution and returned into the magnet. ${ }^{1} \mathrm{H}$ NMR spectra were taken in 5 minute intervals.

The data points for the decay of the starting material 1a align linearly in the coordinate system corresponding to the overall second order in the substrates (Figure 1b), whereas deviations from linearity are present in the coordinate systems corresponding to the 1st and 3rd overall orders (Figures S1 and S2, respectively).

Table S1. Time-course experiment - data

\begin{tabular}{|c|c|c|}
\hline time (min) & [1a] (mM) & [product] (mM) \\
\hline 0 & 38.298 & 0.000 \\
\hline 2 & 30.875 & 5.606 \\
\hline 7 & 30.284 & 6.372 \\
\hline 12 & 29.366 & 6.900 \\
\hline 17 & 28.133 & 7.192 \\
\hline 22 & 27.348 & 7.966 \\
\hline 27 & 26.568 & 8.034 \\
\hline 32 & 26.336 & 8.213 \\
\hline 37 & 25.366 & 8.745 \\
\hline 42 & 24.850 & 9.016 \\
\hline 47 & 24.233 & 9.124 \\
\hline 52 & 23.951 & 9.303 \\
\hline 57 & 23.560 & 9.629 \\
\hline 62 & 23.131 & 10.182 \\
\hline 67 & 22.453 & 10.160 \\
\hline 72 & 22.111 & 10.636 \\
\hline 77 & 21.698 & 10.704 \\
\hline 82 & 21.444 & 10.972 \\
\hline 87 & 21.280 & 11.143 \\
\hline 92 & 20.835 & 11.297 \\
\hline 97 & 20.472 & 11.710 \\
\hline 102 & 20.045 & 11.755 \\
\hline 107 & 20.018 & 11.989 \\
\hline 112 & 19.749 & 11.934 \\
\hline 117 & 19.206 & 12.236 \\
\hline 122 & 18.938 & 12.443 \\
\hline 127 & 18.466 & 12.713 \\
\hline 132 & 18.398 & 12.760 \\
\hline 137 & 18.030 & 12.877 \\
\hline 142 & 17.742 & 13.119 \\
\hline
\end{tabular}




\begin{tabular}{lll}
147 & 17.568 & 13.168 \\
152 & 17.114 & 13.329 \\
157 & 16.912 & 13.416 \\
162 & 16.609 & 13.337 \\
167 & 16.492 & 13.658 \\
172 & 16.220 & 13.842 \\
177 & 16.173 & 13.704 \\
182 & 15.927 & 13.839 \\
187 & 15.477 & 13.972 \\
192 & 15.442 & 14.010 \\
197 & 14.971 & 14.195 \\
202 & 14.815 & 14.251 \\
207 & 14.728 & 14.308 \\
212 & 14.472 & 14.561 \\
217 & 14.105 & 14.460 \\
222 & 14.006 & 14.750 \\
227 & 13.763 & 14.645 \\
232 & 13.591 & 14.704 \\
237 & 13.270 & 14.829 \\
242 & 13.110 & 15.173 \\
247 & 12.843 & 15.321 \\
252 & 12.779 & 15.195 \\
257 & 12.736 & 15.213 \\
262 & 12.567 & 15.133 \\
267 & 12.239 & 15.143 \\
272 & 12.092 & 15.409 \\
277 & 11.983 & 15.483 \\
282 & 11.551 & 15.301 \\
287 & 11.570 & 15.525 \\
292 & 11.186 & 15.888 \\
297 & 11.294 & 15.585 \\
\hline & &
\end{tabular}

Figure S1. Plot of LN $\left([\mathbf{1 a}] /[\mathbf{1 a}]_{0}\right)$ vs. time ${ }^{a}$

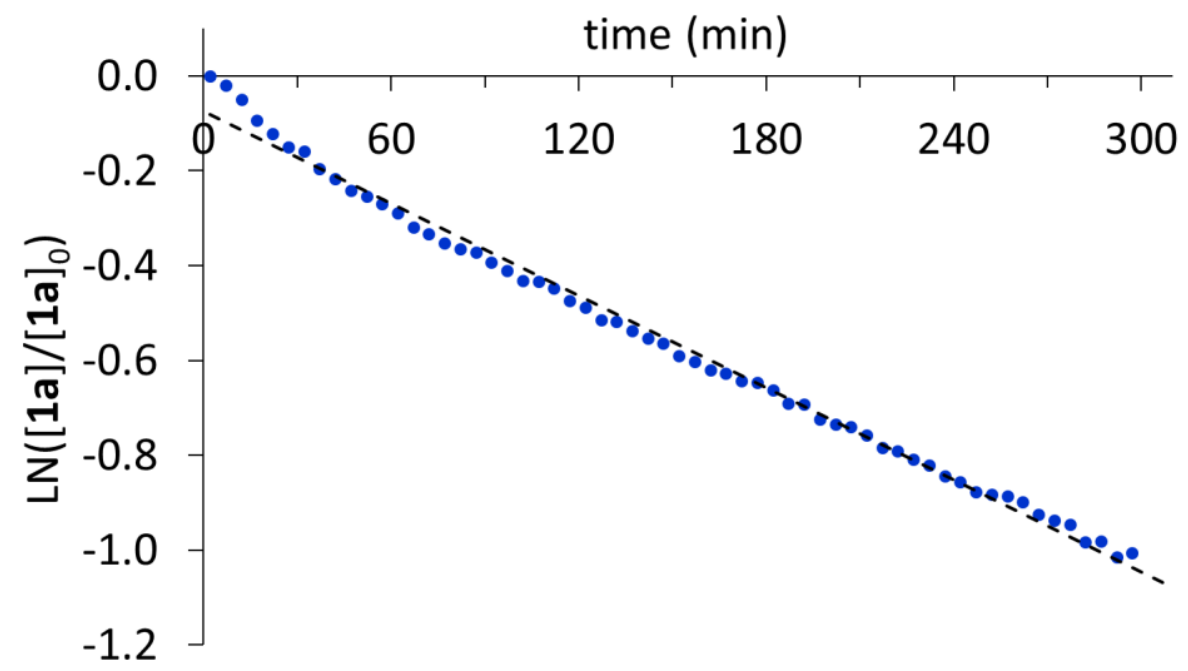

${ }^{a}[\mathbf{1 a}]_{0}$ was taken from the $\mathrm{t}=2 \mathrm{~min}$ spectra, due to the initial leap in the concentration, caused by the temporary heating of the sample during the addition of TMEDA. 
Figure S2. Plot of $[1 \mathbf{a}]^{-2}$ vs. time

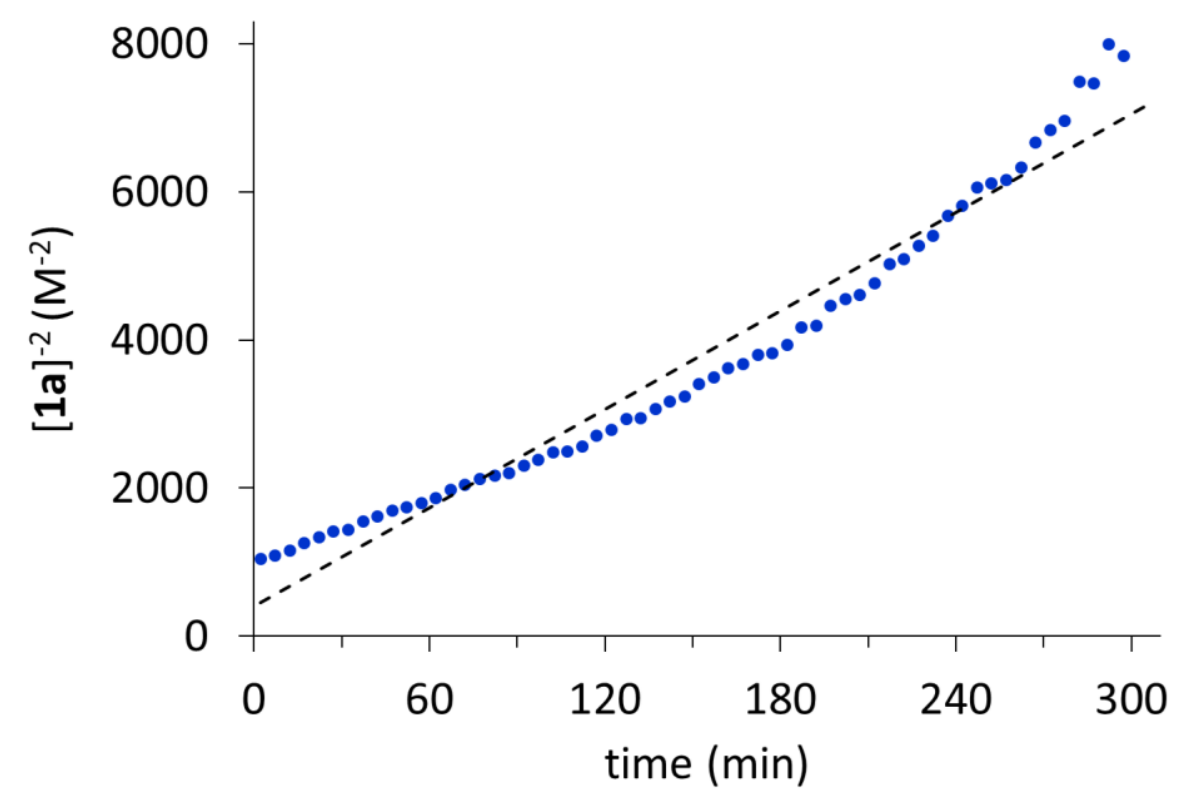

\subsection{Initial Rate Measurements (Figure 2)}

In a nitrogen-atmosphere glovebox, appropriate amounts of stock solutions (see Tables below) of aldehyde 1a, alkynyliodonium salt 2a, catalyst precursor $\mathbf{N H C - 1}$, and $\mathrm{CDCl}_{3}$ were mixed in an $\mathrm{NMR}$ tube. Next, 1-fluorododecane (internal standard) was added. The NMR tube was capped, removed from the glovebox, and inserted into NMR magnet with the probe temperature set to $-40{ }^{\circ} \mathrm{C}$. After $10 \mathrm{~min}$, the NMR tube was removed from the magnet and the appropriate amount of neat TMEDA was quickly added via syringe to initiate the reaction. The NMR tube was shaken to ensure complete mixing of the solution and returned into the magnet. After $3 \mathrm{~min}$ at $-40{ }^{\circ} \mathrm{C},{ }^{1} \mathrm{H}$ NMR spectra were taken in 2 minute intervals.

Due to the unavoidable heating of the sample during the time needed to add TMEDA, in the initial period, the reactions displayed noticeably higher and erratic rates. For this reason, the data from this initial period (first 3 minutes) was not taken into consideration in the initial rate analysis. Hence, the time was set to relative zero only when the first spectra was registered (i.e., $3 \mathrm{~min}$ after the addition of TMEDA) and the concentration of product measured in this first spectra was also set to relative zero. This data is shown in Figure 3 in the article.

In the case of aldehyde 1a and iodonium salt $\mathbf{2 a}$, whose concentrations could be directly determined from the NMR spectra, their 'initial concentrations' are these really measured in the first spectra of a given run. For NHC-1 and TMEDA, the initial concentrations are based on the amounts used when preparing the samples.

\section{Order in Aldehyde}

Table S2. Order in aldehyde - sample preparation

\begin{tabular}{|c|c|c|c|c|c|c|}
\hline run & $\begin{array}{c}\text { 1a solution } \\
26 \mathrm{mM} \text { in } \mathrm{CDCl}_{3} \\
(\mu \mathrm{L}) / \text { final conc. } \\
(\mathrm{mM})\end{array}$ & $\begin{array}{c}\text { 2a solution } \\
30 \mathrm{mM}^{\text {in } \mathrm{CDCl}_{3}} \\
(\mu \mathrm{L}) / \text { final conc. } \\
(\mathrm{mM})\end{array}$ & $\begin{array}{l}\text { NHC-1 solution } \\
88 \mathrm{mM} \text { in } \mathrm{CD}_{3} \mathrm{CN} \\
(\mu \mathrm{L}) / \text { final conc. } \\
(\mathrm{mM})\end{array}$ & $\begin{array}{c}\mathrm{CDCl}_{3} \\
(\mu \mathrm{L})\end{array}$ & $\begin{array}{c}\text { TMEDA } \\
(\mu \mathrm{L}) \\
/ \text { final conc. } \\
(\mathrm{mM}) \\
\end{array}$ & $\begin{array}{c}\mathrm{C}_{12} \mathrm{H}_{25} \mathrm{~F} \\
\mathrm{IS}(\mu \mathrm{L}) \\
/ \text { final conc. } \\
\text { (mM) }\end{array}$ \\
\hline 1 & $350 / 12.5$ & $350 / 15.0$ & $10 / 1.25$ & 0 & $2.0 / 18.7$ & $2.1 / 12.5$ \\
\hline
\end{tabular}




\begin{tabular}{ccccccc}
2 & $266 / 9.5$ & $350 / 15.0$ & $10 / 1.25$ & 84 & $2.0 / 18.7$ & $2.1 / 12.5$ \\
3 & $224 / 8.0$ & $350 / 15.0$ & $10 / 1.25$ & 126 & $2.0 / 18.7$ & $2.1 / 12.5$ \\
4 & $182 / 6.5$ & $350 / 15.0$ & $10 / 1.25$ & 168 & $2.0 / 18.7$ & $2.1 / 12.5$ \\
\hline
\end{tabular}

Table S3. Order in aldehyde - data

\begin{tabular}{|c|c|c|}
\hline $\begin{array}{l}\text { time } \\
\text { (min) }\end{array}$ & $\begin{array}{c}\text { measured } \\
\text { [product }(\mathrm{mM})\end{array}$ & $\begin{array}{c}\text { relative } \\
\text { [product] }(\mathrm{mM})\end{array}$ \\
\hline \multicolumn{3}{|c|}{ run 1 - [1a] measured in the first spectra: $6.30 \mathrm{mM}$} \\
\hline 0 & 1.970 & 0.000 \\
\hline 2 & 2.143 & 0.173 \\
\hline 4 & 2.224 & 0.253 \\
\hline 6 & 2.544 & 0.574 \\
\hline 8 & 2.704 & 0.734 \\
\hline 10 & 2.697 & 0.726 \\
\hline \multicolumn{3}{|c|}{ initial rate: $0.081 \pm 0.010 \mathrm{mM} / \mathrm{min}$} \\
\hline \multicolumn{3}{|c|}{ run 2 - [1a] measured in the first spectra: $5.1 \mathrm{mM}$} \\
\hline 0 & 1.801 & 0.000 \\
\hline 2 & 1.959 & 0.158 \\
\hline 4 & 2.170 & 0.369 \\
\hline 6 & 2.302 & 0.500 \\
\hline 8 & 2.482 & 0.680 \\
\hline 10 & 2.588 & 0.786 \\
\hline \multicolumn{3}{|c|}{ initial rate: $0.080 \pm 0.003 \mathrm{mM} / \mathrm{min}$} \\
\hline \multicolumn{3}{|c|}{ run 3 - [1a] measured in the first spectra: $3.8 \mathrm{mM}$} \\
\hline 0 & 1.033 & 0.000 \\
\hline 2 & 1.154 & 0.121 \\
\hline 4 & 1.270 & 0.237 \\
\hline 6 & 1.349 & 0.315 \\
\hline 8 & 1.463 & 0.429 \\
\hline 10 & 1.579 & 0.546 \\
\hline \multicolumn{3}{|c|}{ initial rate: $0.053 \pm 0.001 \mathrm{mM} / \mathrm{min}$} \\
\hline \multicolumn{3}{|c|}{ run 4 - [1a] measured in the first spectra: $2.2 \mathrm{mM}$} \\
\hline 0 & 1.088 & 0.000 \\
\hline 2 & 1.132 & 0.045 \\
\hline 4 & 1.156 & 0.069 \\
\hline 6 & 1.305 & 0.217 \\
\hline 8 & 1.378 & 0.290 \\
\hline 10 & 1.418 & 0.330 \\
\hline \multicolumn{3}{|c|}{ initial rate: $0.036 \pm 0.004 \mathrm{mM} / \mathrm{min}$} \\
\hline
\end{tabular}

\section{Order in alkynyliodonium salt}

Table S4. Order in alkynyliodonium salt - sample preparation

\begin{tabular}{ccccccc}
\hline run & $\begin{array}{c}\text { 1a solution } \\
90 \mathrm{mM} \text { in } \mathrm{CDCl}_{3} \\
(\mu \mathrm{L}) / \text { final conc. } \\
(\mathrm{mM})\end{array}$ & $\begin{array}{c}\text { 2a solution } \\
42 \mathrm{mM} \mathrm{in} \mathrm{CDCl})_{3} \\
(\mu \mathrm{L}) / \text { final conc. } \\
(\mathrm{mM})\end{array}$ & $\begin{array}{c}\text { NHC-1 solution } \\
\begin{array}{c}175 \mathrm{mM} \text { in } \mathrm{CD}_{3} \mathrm{CN} \\
(\mu \mathrm{L}) / \text { final conc. } \\
(\mathrm{mM})\end{array}\end{array}$ & $\begin{array}{c}\mathrm{CDCl}_{3} \\
(\mu \mathrm{L})\end{array}$ & $\begin{array}{c}\text { TMEDA } \\
(\mu \mathrm{L}) \\
/ \text { final conc. } \\
(\mathrm{mM})\end{array}$ & $\begin{array}{c}\mathrm{C}_{12} \mathrm{H}_{25} \mathrm{~F} \\
\mathrm{IS}(\mu \mathrm{L}) \\
/ \text { final conc. } \\
(\mathrm{mM})\end{array}$ \\
\hline 1 & $200 / 25.0$ & $500 / 30.0$ & $10 / 2.5$ & 0 & $7.9 / 37.4$ & $4.2 / 25.0$ \\
2 & $200 / 25.0$ & $450 / 27.0$ & $10 / 2.5$ & 50 & $7.9 / 37.4$ & $4.2 / 25.0$ \\
3 & $200 / 25.0$ & $400 / 24.0$ & $10 / 2.5$ & 100 & $7.9 / 37.4$ & $4.2 / 25.0$ \\
4 & $200 / 25.0$ & $350 / 21.0$ & $10 / 2.5$ & 150 & $7.9 / 37.4$ & $4.2 / 25.0$ \\
5 & $200 / 25.0$ & $300 / 17.0$ & $10 / 2.5$ & 200 & $7.9 / 37.4$ & $4.2 / 25.0$ \\
\hline
\end{tabular}


Table S5. Order in alkynyliodonium salt - data

\begin{tabular}{ccc}
\hline $\begin{array}{c}\text { time } \\
\text { (min) }\end{array}$ & $\begin{array}{c}\text { measured } \\
\text { [product] (mM) }\end{array}$ & $\begin{array}{c}\text { relative } \\
\text { [product] (mM) }\end{array}$ \\
\hline run 1 - [2a] & measured in the first spectra: $18.0 \mathrm{mM}$ \\
\hline 0 & 3.256 & 0.000 \\
2 & 3.626 & 0.370 \\
4 & 4.043 & 0.788 \\
6 & 4.271 & 1.015 \\
8 & 4.604 & 1.348 \\
10 & 4.937 & 1.681 \\
12 & 5.132 & 1.877 \\
initial rate: & $\mathbf{0 . 1 5 7} \mathbf{0 . 0 0 6} \mathbf{m M} /$ min \\
\hline run 2 - [2a] & \\
\hline 0 & 3.364 & 0.000 \\
2 & 3.655 & 0.291 \\
4 & 3.939 & 0.575 \\
6 & 4.158 & 0.794 \\
8 & 4.402 & 1.038 \\
10 & 4.580 & 1.215 \\
12 & 4.752 & 1.388
\end{tabular}

initial rate: $0.116 \pm 0.005 \mathrm{mM} / \mathrm{min}$

run 3 - [2a] measured in the first spectra: $13.6 \mathrm{mM}$

$\begin{array}{ccc}0 & 2.765 & 0.000 \\ 2 & 3.069 & 0.303 \\ 4 & 3.411 & 0.645 \\ 6 & 3.575 & 0.810 \\ 8 & 3.827 & 1.061 \\ 10 & 4.082 & 1.317 \\ 12 & 4.208 & 1.443\end{array}$

initial rate: $0.121 \pm 0.006 \mathrm{mM} / \mathrm{min}$

\begin{tabular}{ccc}
\hline run $\mathbf{4}$ - [2a] & measured in the first spectra: $10.6 \mathrm{mM}$ \\
\hline 0 & 3.166 & 0.000 \\
2 & 3.443 & 0.277 \\
4 & 3.714 & 0.547 \\
6 & 3.964 & 0.798 \\
8 & 4.211 & 1.045 \\
10 & 4.458 & 1.292 \\
12 & 4.574 & 1.408 \\
initial rate: $\mathbf{0 . 1 2 1} \mathbf{0 . 0 0 5} \mathbf{~ m M / m i n}$ & \\
\hline run 5 $-[\mathbf{2 a}]$ & measured in the first spectra: $9.9 \mathrm{mM}$ \\
\hline 0 & 2.596 & 0.000 \\
2 & 2.950 & 0.354 \\
4 & 3.348 & 0.752 \\
6 & 3.734 & 1.138 \\
8 & 3.923 & 1.327 \\
10 & 4.169 & 1.573 \\
12 & 4.313 & 1.717 \\
initial rate: $\mathbf{0 . 1 4 6} \pm \mathbf{0 . 0 1 1} \mathbf{m M} / \mathbf{m i n}$ &
\end{tabular}

\section{Order in TMEDA}

Table S6. Order in TMEDA - sample preparation

\begin{tabular}{|c|c|c|c|c|c|c|}
\hline run & 1a solution & $2 a$ solution & NHC-1 solution & $\begin{array}{c}\mathrm{CDCl}_{3} \\
(\mu \mathrm{L})\end{array}$ & $\begin{array}{c}\text { TMEDA } \\
(\mu \mathrm{L})\end{array}$ & $\begin{array}{l}\mathrm{C}_{12} \mathrm{H}_{25} \mathrm{~F} \\
\mathrm{IS}(\mu \mathrm{L})\end{array}$ \\
\hline
\end{tabular}




\begin{tabular}{|c|c|c|c|c|c|c|}
\hline & $\begin{array}{c}26 \mathrm{mM} \text { in } \mathrm{CDCl}_{3} \\
(\mu \mathrm{L}) / \text { final conc. } \\
(\mathrm{mM})\end{array}$ & $\begin{array}{c}30 \mathrm{mM} \text { in } \mathrm{CDCl}_{3} \\
(\mu \mathrm{L}) / \text { final conc. } \\
(\mathrm{mM})\end{array}$ & $\begin{array}{c}88 \mathrm{mM} \text { in } \mathrm{CD}_{3} \mathrm{CN} \\
(\mu \mathrm{L}) / \text { final conc. } \\
(\mathrm{mM})\end{array}$ & & $\begin{array}{l}\text { /final conc. } \\
(\mathrm{mM})\end{array}$ & $\begin{array}{l}\text { /final conc. } \\
(\mathrm{mM})\end{array}$ \\
\hline 1 & $350 / 12.5$ & $350 / 15.0$ & $10 / 1.25$ & 0 & $2.3 / 21.9$ & $2.1 / 12.5$ \\
\hline 2 & $350 / 12.5$ & $350 / 15.0$ & $10 / 1.25$ & 0 & $2.0 / 19.0$ & $2.1 / 12.5$ \\
\hline 3 & $350 / 12.5$ & $350 / 15.0$ & $10 / 1.25$ & 0 & $1.9 / 18.1$ & $2.1 / 12.5$ \\
\hline 4 & $350 / 12.5$ & $350 / 15.0$ & $10 / 1.25$ & 0 & $1.8 / 17.1$ & $2.1 / 12.5$ \\
\hline 5 & $350 / 12.5$ & $350 / 15.0$ & $10 / 1.25$ & 0 & $1.7 / 16.2$ & $2.1 / 12.5$ \\
\hline
\end{tabular}

Table S7. Order in TMEDA - data

\begin{tabular}{|c|c|c|}
\hline $\begin{array}{c}\text { time } \\
(\min )\end{array}$ & $\begin{array}{c}\text { measured } \\
\text { [product] }(\mathrm{mM})\end{array}$ & $\begin{array}{c}\text { relative } \\
\text { [product] }(\mathrm{mM}) \\
\end{array}$ \\
\hline \multicolumn{3}{|c|}{ run $1-[T M E D A]=21.9 \mathrm{mM}$} \\
\hline 2.422 & 0.000 & 2.422 \\
\hline 2.702 & 0.281 & 2.702 \\
\hline 2.911 & 0.489 & 2.911 \\
\hline 3.007 & 0.585 & 3.007 \\
\hline \multicolumn{3}{|c|}{ initial rate: $0.098 \pm 0.015 \mathrm{mM} / \mathrm{min}$} \\
\hline \multicolumn{3}{|c|}{ run $2-[T M E D A]=19.0 \mathrm{mM}$} \\
\hline 2.658 & 0.000 & 2.658 \\
\hline 2.853 & 0.195 & 2.853 \\
\hline 3.011 & 0.353 & 3.011 \\
\hline 2.965 & 0.307 & 2.965 \\
\hline \multicolumn{3}{|c|}{ initial rate: $0.054 \pm 0.020 \mathrm{mM} / \mathrm{min}$} \\
\hline \multicolumn{3}{|c|}{ run $3-[T M E D A]=18.1 \mathrm{mM}$} \\
\hline 0 & 2.490 & 0.000 \\
\hline 2 & 2.628 & 0.000 \\
\hline 4 & 2.683 & 0.055 \\
\hline 6 & 2.850 & 0.222 \\
\hline \multicolumn{3}{|c|}{ initial rate: $0.057 \pm 0.007 \mathrm{mM} / \mathrm{min}$} \\
\hline \multicolumn{3}{|c|}{ run 4 - [TMEDA] $=17.1 \mathrm{mM}$} \\
\hline 0 & 2.535 & 0.000 \\
\hline 2 & 2.593 & 0.059 \\
\hline 4 & 2.781 & 0.246 \\
\hline 6 & 2.980 & 0.446 \\
\hline \multicolumn{3}{|c|}{ initial rate: $0.076 \pm 0.012 \mathrm{mM} / \mathrm{min}$} \\
\hline \multicolumn{3}{|c|}{ run $5-[$ TMEDA] $=16.2 \mathrm{mM}$} \\
\hline 0 & 2.553 & 0.000 \\
\hline 2 & 2.667 & 0.114 \\
\hline 4 & 2.765 & 0.212 \\
\hline 6 & 2.931 & 0.378 \\
\hline \multicolumn{3}{|c|}{ initial rate: $0.062 \pm 0.005 \mathrm{mM} / \mathrm{min}$} \\
\hline
\end{tabular}

\section{Order in NHC precursor}

Table S8. Order in NHC precursor - sample preparation

\begin{tabular}{ccccccc}
\hline run & $\begin{array}{c}\text { 1a solution } \\
26 \mathrm{mM} \text { in } \mathrm{CDCl}_{3} \\
(\mu \mathrm{L}) / \text { final conc. } \\
(\mathrm{mM})\end{array}$ & $\begin{array}{c}\text { 2a solution } \\
30 \mathrm{mM} \text { in } \mathrm{CDCl}_{3} \\
(\mu \mathrm{L}) / \text { final conc. } \\
(\mathrm{mM})\end{array}$ & $\begin{array}{c}\text { NHC-1 solution } \\
88 \mathrm{mM} \text { in } \mathrm{CD}_{3} \mathrm{CN} \\
(\mu \mathrm{L}) / \text { final conc. } \\
(\mathrm{mM})\end{array}$ & $\begin{array}{c}\mathrm{CDCl}_{3} \\
(\mu \mathrm{L})\end{array}$ & $\begin{array}{c}\text { TMEDA } \\
(\mu \mathrm{L}) \\
/ \text { final conc. } \\
(\mathrm{mM})\end{array}$ & $\begin{array}{c}\mathrm{C}_{12} \mathrm{H}_{25} \mathrm{~F} \\
\text { IS }(\mu \mathrm{L}) \\
/ \text { final conc. } \\
(\mathrm{mM})\end{array}$ \\
\hline 1 & $350 / 12.5$ & $350 / 15.0$ & $20 / 2.50$ & 0 & $2.0 / 18.7$ & $2.1 / 12.5$ \\
2 & $350 / 12.5$ & $350 / 15.0$ & $18 / 2.25$ & 0 & $2.0 / 18.7$ & $2.1 / 12.5$ \\
3 & $350 / 12.5$ & $350 / 15.0$ & $16 / 2.00$ & 0 & $2.0 / 18.7$ & $2.1 / 12.5$ \\
4 & $350 / 12.5$ & $350 / 15.0$ & $14 / 1.75$ & 0 & $2.0 / 18.7$ & $2.1 / 12.5$
\end{tabular}


Table S9. Order in NHC precursor - data

\begin{tabular}{ccc}
\hline $\begin{array}{c}\text { time } \\
(\mathrm{min})\end{array}$ & $\begin{array}{c}\text { measured } \\
\text { [product] }(\mathrm{mM})\end{array}$ & $\begin{array}{c}\text { relative } \\
\text { [product] }(\mathrm{mM})\end{array}$ \\
\hline run 1 $-[$ NHC-1] $=2.50 \mathrm{mM}$ & \\
\hline 0 & 3.776 & 0.000 \\
2 & 4.279 & 0.503 \\
4 & 4.781 & 1.005 \\
6 & 4.780 & 1.004 \\
8 & 5.027 & 1.251 \\
10 & 6.004 & 2.228 \\
12 & 5.335 & 1.559
\end{tabular}

initial rate: $0.150 \pm 0.032 \mathrm{mM} / \mathrm{min}$

\begin{tabular}{ccc}
\hline run 2 - [NHC-1] $=$ & $2.25 \mathrm{mM}$ & \\
\hline 0 & 3.364 & 0.000 \\
2 & 3.644 & 0.281 \\
4 & 3.983 & 0.620 \\
6 & 4.374 & 1.010 \\
8 & 4.643 & 1.279 \\
10 & 4.761 & 1.397 \\
12 & 5.032 & 1.669
\end{tabular}

initial rate: $0.141 \pm 0.008 \mathrm{mM} / \mathrm{min}$ run 3 - [NHC-1] $=2.00 \mathrm{mM}$

$\begin{array}{ccc}0 & 4.054 & 0.000 \\ 2 & 4.372 & 0.318 \\ 4 & 4.659 & 0.605 \\ 6 & 4.739 & 0.684 \\ 8 & 5.102 & 1.048 \\ 10 & 5.137 & 1.083 \\ 12 & 5.312 & 1.258\end{array}$

initial rate: $0.103 \pm 0.009 \mathrm{mM} / \mathrm{min}$

\begin{tabular}{|c|c|c|}
\hline \multicolumn{3}{|c|}{ run 4 - [NHC-1] $=1.75 \mathrm{mM}$} \\
\hline 0 & 2.725 & 0.000 \\
\hline 2 & 2.929 & 0.204 \\
\hline 4 & 3.502 & 0.776 \\
\hline 6 & 3.876 & 1.150 \\
\hline 8 & 3.820 & 1.094 \\
\hline 10 & 4.231 & 1.505 \\
\hline 12 & 4.136 & 1.410 \\
\hline \multicolumn{3}{|c|}{ initial rate: $0.128 \pm 0.019 \mathrm{mM} / \mathrm{min}$} \\
\hline \multicolumn{3}{|c|}{ run 5 - [NHC-1]=1.50 mM } \\
\hline 0 & 2.326 & 0.000 \\
\hline 2 & 2.621 & 0.295 \\
\hline 4 & 2.688 & 0.361 \\
\hline 6 & 2.885 & 0.559 \\
\hline 8 & 3.030 & 0.704 \\
\hline 10 & 3.088 & 0.762 \\
\hline 12 & 3.427 & 1.101 \\
\hline \multicolumn{3}{|c|}{ initial rate: $0.082 \pm 0.007 \mathrm{mM} / \mathrm{min}$} \\
\hline
\end{tabular}




\section{Computational Details}

The calculations were carried out with Gaussian 16 software package ${ }^{44}$ using B3LYP functional, ${ }^{45}$ including the D3 dispersion correction with the BJ dumping ${ }^{46}$ Geometries were optimized with SMD solvation model, ${ }^{47}$ using Def2-SVPD basis set ${ }^{48}$ that includes a pseudopotential for iodine. ${ }^{49}$ For each stationary point a thorough conformational analysis was performed in order to locate the conformer with the lowest energy. This was done by identifying key rotatable bonds and movable entities (e.g. $\mathrm{BF}_{4}^{-}$ ion), and manually building possible starting geometries for optimizations.

The identified lowest energy stationary points were then characterized by frequency calculations to confirm their character as minima (no imaginary frequencies) or transition states (one single imaginary frequency). The final free energies were obtained from single-point calculations on the optimized geometries with a larger Def2-QZVP basis set ${ }^{4 a, 50}$ (with SMD solvation) and were corrected for the thermodynamic effects using the quasi-harmonic approximation ${ }^{51}$ as implemented in GoodVibes program. $^{52}$

\footnotetext{
${ }^{44}$ Gaussian 16, Revision A.03, M. J. Frisch, G. W. Trucks, H. B. Schlegel, G. E. Scuseria, M. A. Robb, J. R. Cheeseman, G. Scalmani, V. Barone, G. A. Petersson, H. Nakatsuji, X. Li, M. Caricato, A. V. Marenich, J. Bloino, B. G. Janesko, R. Gomperts, B. Mennucci, H. P. Hratchian, J. V. Ortiz, A. F. Izmaylov, J. L. Sonnenberg, D. Williams-Young, F. Ding, F. Lipparini, F. Egidi, J. Goings, B. Peng, A. Petrone, T. Henderson, D. Ranasinghe, V. G. Zakrzewski, J. Gao, N. Rega, G. Zheng, W. Liang, M. Hada, M. Ehara, K. Toyota, R. Fukuda, J. Hasegawa, M. Ishida, T. Nakajima, Y. Honda, O. Kitao, H. Nakai, T. Vreven, K. Throssell, J. A. Montgomery, Jr., J. E. Peralta, F. Ogliaro, M. J. Bearpark, J. J. Heyd, E. N. Brothers, K. N. Kudin, V. N. Staroverov, T. A. Keith, R. Kobayashi, J. Normand, K. Raghavachari, A. P. Rendell, J. C. Burant, S. S. Iyengar, J. Tomasi, M. Cossi, J. M. Millam, M. Klene, C. Adamo, R. Cammi, J. W. Ochterski, R. L. Martin, K. Morokuma, O. Farkas, J. B. Foresman, and D. J. Fox, Gaussian, Inc., Wallingford CT, 2016.

${ }^{45}$ (a) Lee, C.; Yang, W.; Parr, R. G. Phys. Rev. B 1988, 37, 785-789; (b) Becke, A. D. Phys. Rev. A 1988, 38, 3098-3100; (c) Becke, A. D. J. Chem. Phys. 1992, 96, 2155-2160; (d) Becke, A. D. J. Chem. Phys. 1992, 97, 9173-9177; (e) Becke, A. D. J. Chem. Phys. 1993, 98, 56485652.

${ }^{46}$ (a) Grimme, S.; Antony, J.; Ehrlich, S.; Krieg, H. J. Chem. Phys. 2010, 132, 154104; (b) Grimme, S.; Ehrlich, S.; Goerigk, L. J. Comput. Chem. 2011, 32, 1456-1465.

${ }^{47}$ Marenich, A. V.; Cramer, C. J.; Truhlar, D. G. J. Phys. Chem. B 2009, 113, 6378-6396.

48 (a) Weigend, F.; Ahlrichs, R. Phys. Chem. Chem. Phys. 2005, 7, 3297-3305; (b) Rappoport, D.; Furche, F. J. Chem. Phys. 2010, $133,134105$.

${ }^{49}$ Peterson, K. A.; Figgen, D.; Goll, E.; Stoll, H.; Dolg, M. J. Chem. Phys. 2003, 119, 11113-11123.

${ }^{50}$ Weigend, F.; Furche, F.; Ahlrichs, R. J. Chem. Phys. 2003, 119, 12753-12762.

${ }^{51}$ Grimme, S. Chem. Eur. J. 2012, 18, 9955-9964.

${ }^{52}$ Funes-Ardoiz, I.; Paton, R. S. GoodVibes, verison 2.01, 2018.
} 


\section{Free Energy Profile for the Reaction in $\mathrm{CHCl}_{3}$}

Figure S3. Free energy profile for the alkynylation of 2-pyridinecarboxaldehyde (1g) with (mesityl)phenylacetyleneiodonium tosylate (2a) using precatalyst $\mathbf{N H C - 1}$ in $\mathrm{CHCl}_{3}$, calculated at B3LYP-D3BJ/Def2-QZVP(SMD)//B3LYP-D3BJ/Def2-SVPD(SMD) level of theory.

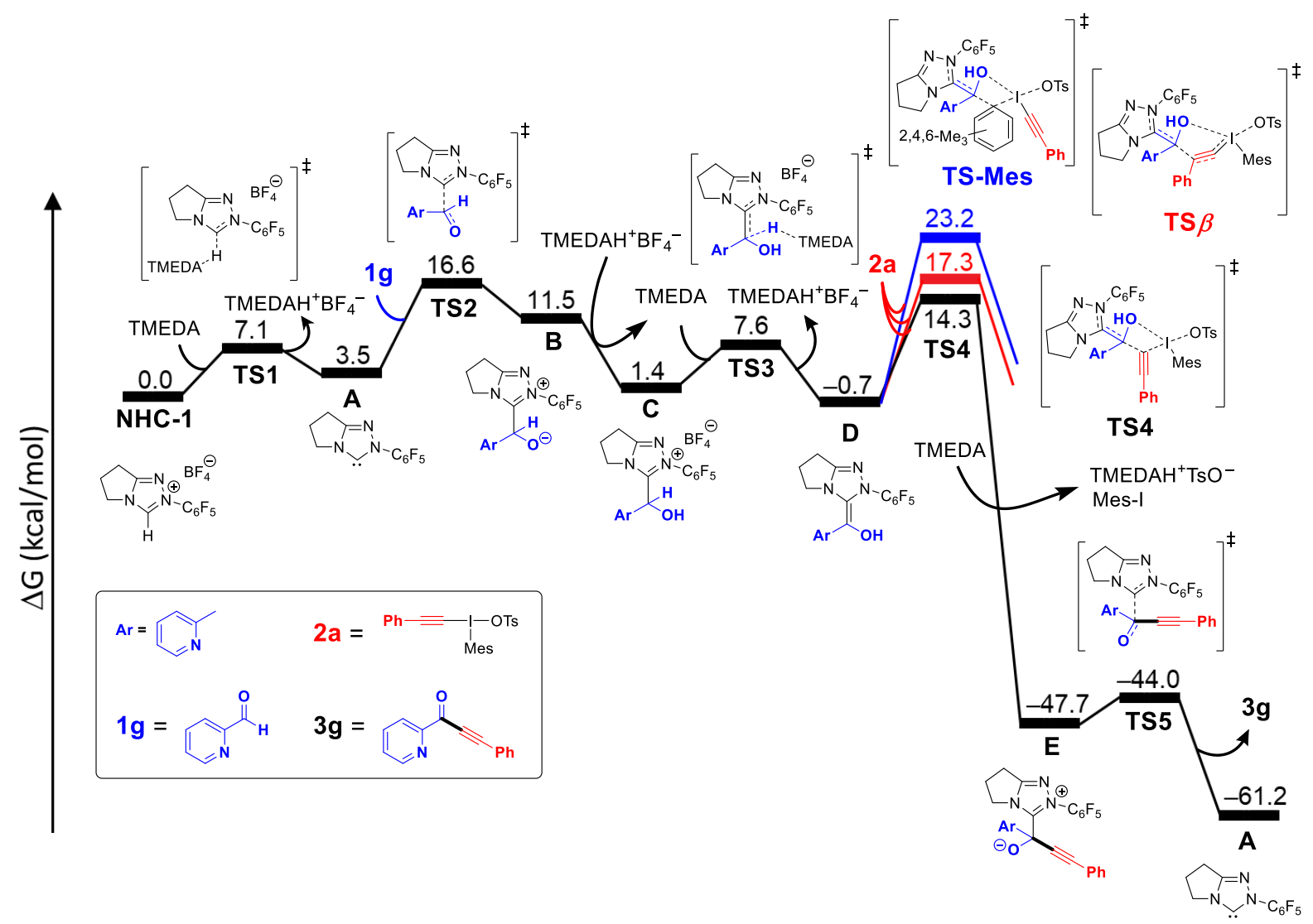

\section{Energies and Energy Corrections of Stationary Points (in atomic units)}

Table S10. Data for calculations in toluene

\begin{tabular}{crrr}
\hline $\begin{array}{c}\text { Stationary } \\
\text { point }\end{array}$ & $\begin{array}{r}\text { B3LYP-D3BJ/ } \\
\text { Def2-SVPD }(\text { SMD toluene) } \\
\text { optimization }\end{array}$ & $\begin{array}{r}\text { Def2-QZVP } \\
\text { (SMD toluene) } \\
\text { single-point }\end{array}$ & $\begin{array}{r}\text { Thermal correction to } \\
\text { Gibbs free energy } \\
\text { (at 233.15 K) }\end{array}$ \\
\hline $\mathbf{1 g}$ & -361.658223 & -361.804366 & 0.075548 \\
$\mathbf{2 a}$ & -1563.690802 & -1850.665988 & 0.365256 \\
$\mathbf{3 g}$ & -668.917231 & -669.181297 & 0.161041 \\
$\mathbf{A}$ & -1086.239763 & -1086.701756 & 0.133159 \\
$\mathbf{B}$ & -1447.904831 & -1448.509885 & 0.229864 \\
$\mathbf{C}$ & -1873.049101 & -1873.851283 & 0.253921 \\
$\mathbf{D}$ & -1447.927274 & -1448.534967 & 0.230342 \\
$\mathbf{E}$ & -1755.157362 & -1755.879604 & 0.314972 \\
Mes-I & -361.056776 & -647.605231 & 0.145528 \\
NHC-1 & -1511.368016 & -1512.027553 & 0.157098 \\
TMEDA & -347.813622 & -347.950192 & 0.197720
\end{tabular}




\begin{tabular}{crrr} 
TMEDAH $^{+} \mathrm{BF}_{4}{ }^{-}$ & -772.941928 & -773.273989 & 0.223515 \\
TMEDAH $^{+}$TsO- $^{-}$ & -1243.301284 & -1243.741586 & 0.336364 \\
TS1 & -1859.194148 & -1859.984828 & 0.371678 \\
TS2 & -1447.897757 & -1448.503254 & 0.228516 \\
TS3 & -2220.875742 & -2221.809001 & 0.468107 \\
TS4 & -3011.626023 & -3299.202145 & 0.619004 \\
TS5 & -1755.148092 & -1755.870652 & 0.313341 \\
TS $\beta$ & -3011.617075 & -3299.192656 & 0.619290 \\
TS-Mes & -3011.607351 & -3299.184117 & 0.617980 \\
\hline
\end{tabular}

Table S11. Data for calculations in $\mathrm{CHCl}_{3}$

\begin{tabular}{|c|c|c|c|}
\hline $\begin{array}{c}\text { Stationary } \\
\text { point }\end{array}$ & $\begin{array}{r}\text { B3LYP-D3BJ/ } \\
\text { Def2-SVPD (SMD CHCl }) \\
\text { optimization }\end{array}$ & $\begin{array}{r}\text { B3LYP-D3BJ/ } \\
\text { Def2-QZVP (SMD CHCl }) \\
\text { single-point }\end{array}$ & $\begin{array}{r}\text { Thermal correction to } \\
\text { Gibbs free energy } \\
\text { (at } 233.15 \mathrm{~K})\end{array}$ \\
\hline $1 \mathrm{~g}$ & -361.660059 & -361.805902 & 0.075436 \\
\hline $2 a$ & -1563.699743 & -1850.674148 & 0.364346 \\
\hline $3 g$ & -668.920149 & -669.183817 & 0.160945 \\
\hline A & -1086.243036 & -1086.704712 & 0.133009 \\
\hline B & -1447.915655 & -1448.520072 & 0.230537 \\
\hline C & -1873.064797 & -1873.866457 & 0.254010 \\
\hline D & -1447.931861 & -1448.538932 & 0.230047 \\
\hline $\mathbf{E}$ & -1755.167157 & -1755.888638 & 0.315522 \\
\hline Mes-I & -361.058298 & -647.606570 & 0.145353 \\
\hline NHC-1 & -1511.381319 & -1512.040479 & 0.156313 \\
\hline TMEDA & -347.816190 & -347.952533 & 0.197828 \\
\hline $\mathrm{TMEDAH}^{+} \mathrm{BF}_{4}^{-}$ & -772.953367 & -773.285167 & 0.223612 \\
\hline TMEDAH $^{+}$TsO $^{-}$ & -1243.310781 & -1243.750500 & 0.336521 \\
\hline TS1 & -1859.208220 & -1859.998731 & 0.371194 \\
\hline TS2 & -1447.904218 & -1448.509199 & 0.227861 \\
\hline TS3 & -2220.892385 & -2221.825560 & 0.468396 \\
\hline TS4 & -3011.638901 & -3299.214125 & 0.619415 \\
\hline TS5 & -1755.158803 & -1755.881007 & 0.313794 \\
\hline TS $\beta$ & -3011.632857 & -3299.207485 & 0.617465 \\
\hline TS-Mes & -3011.622360 & -3299.197981 & 0.617433 \\
\hline
\end{tabular}




\section{NMR Spectra of Compounds $2 \mathrm{w}$ and 3a-3ab}

${ }^{1} \mathrm{H} \mathrm{NMR}, 500 \mathrm{MHz}, \mathrm{CDCl}_{3}$
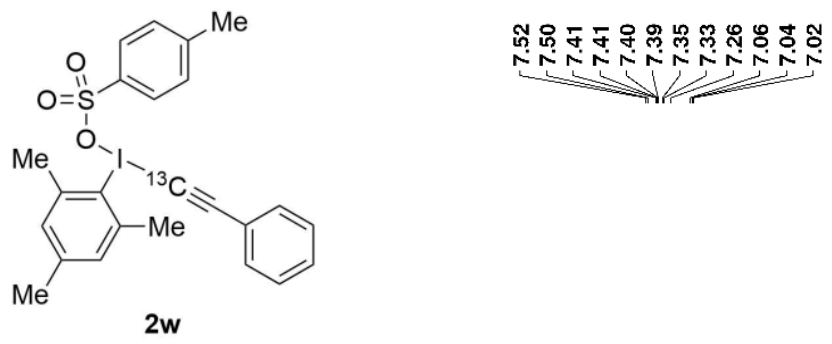

กำ

2w

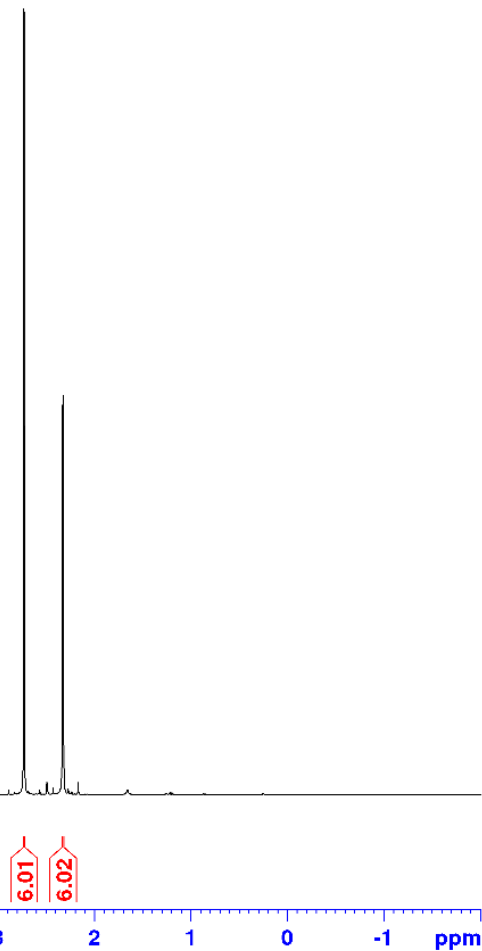

${ }^{13} \mathrm{C}$ NMR (without $\mathrm{NOE}$ ), $126 \mathrm{MHz}, \mathrm{CDCl}_{3}$

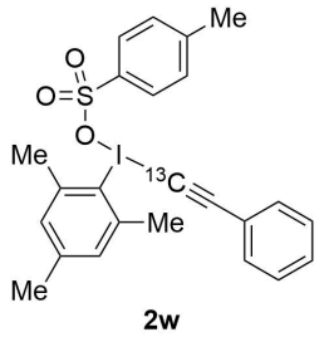

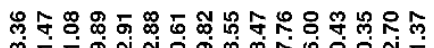
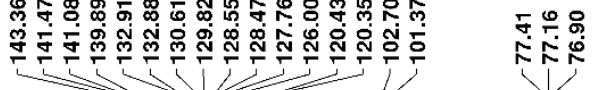

กิ นดำ

\%ำ응

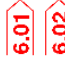

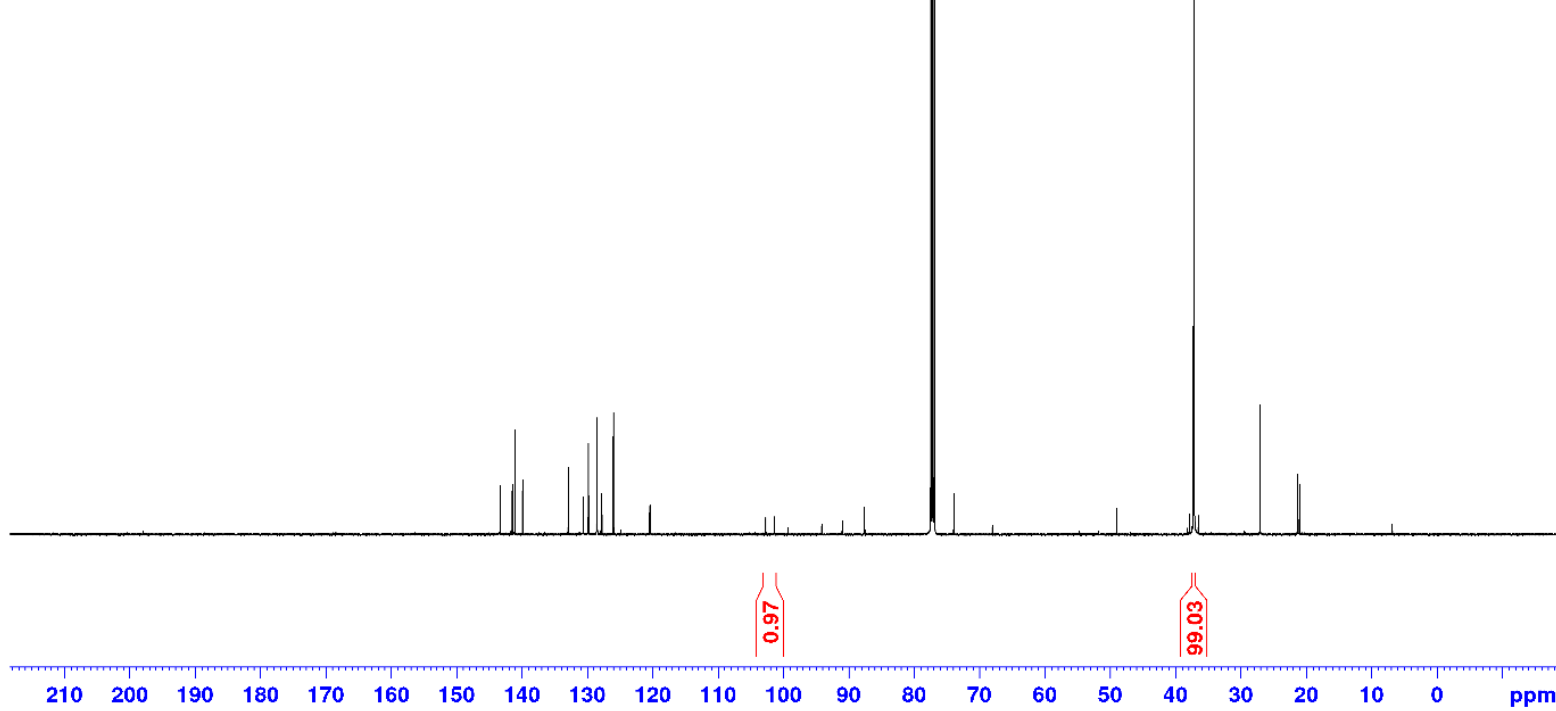


${ }^{1} \mathrm{H}$ NMR, $500 \mathrm{MHz}, \mathrm{CDCl}_{3}$

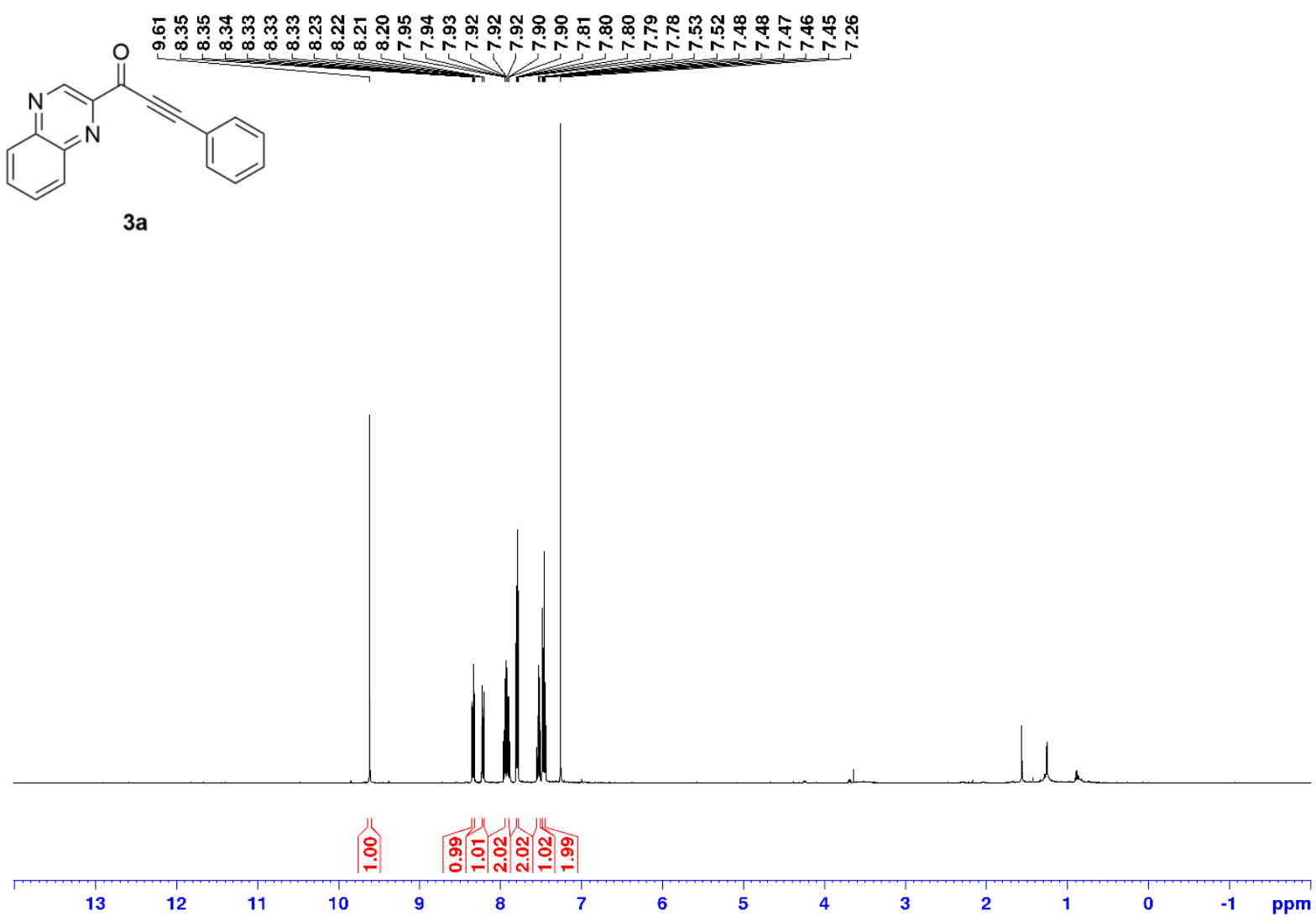

${ }^{13} \mathrm{C}$ NMR, $126 \mathrm{MHz}, \mathrm{CDCl}_{3}$

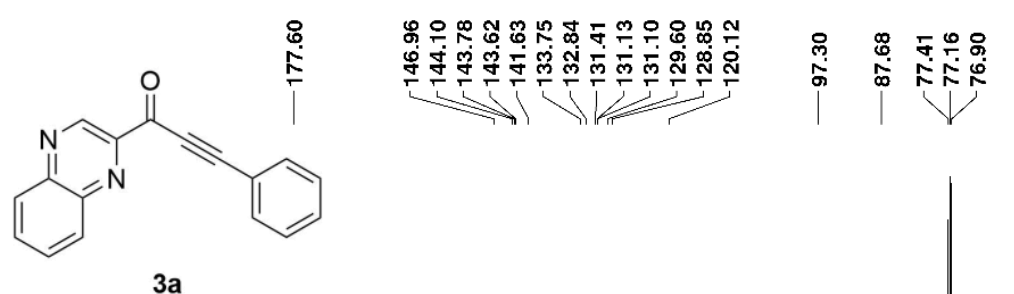

3a

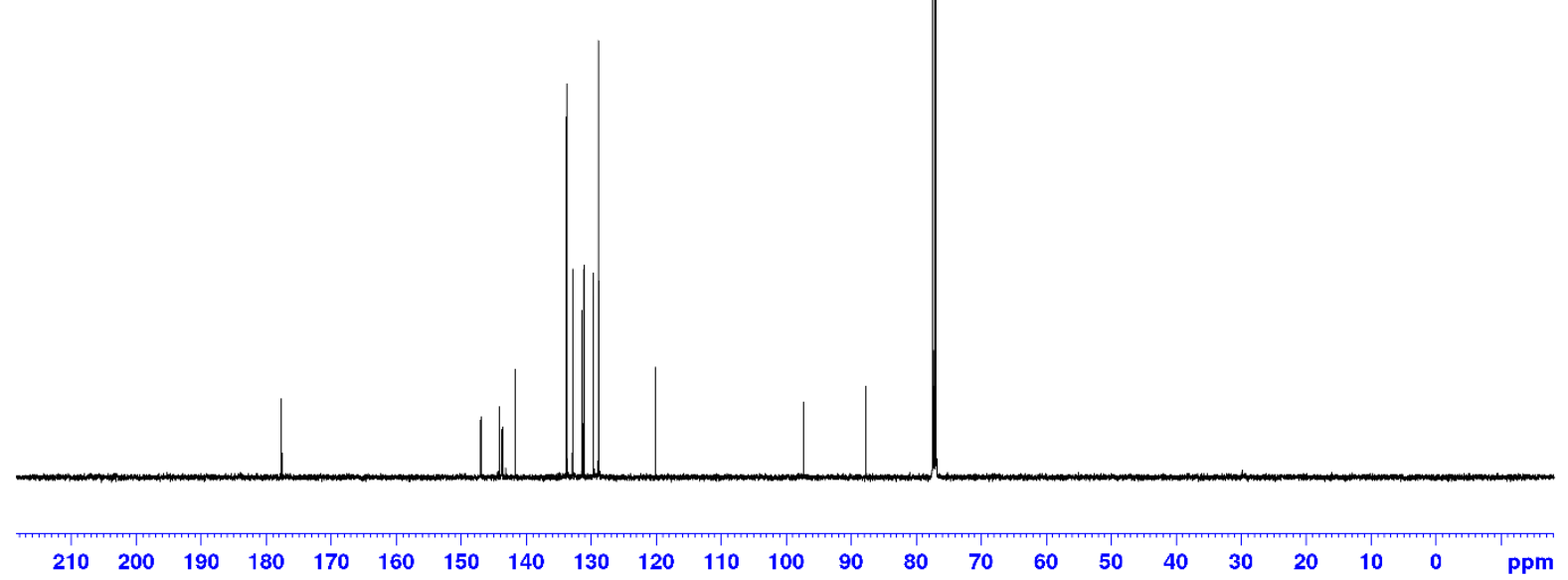


${ }^{1} \mathrm{H} \mathrm{NMR}, 500 \mathrm{MHz}, \mathrm{CDCl}_{3}$

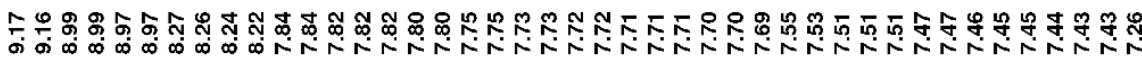

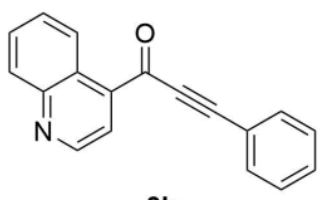

$3 b$

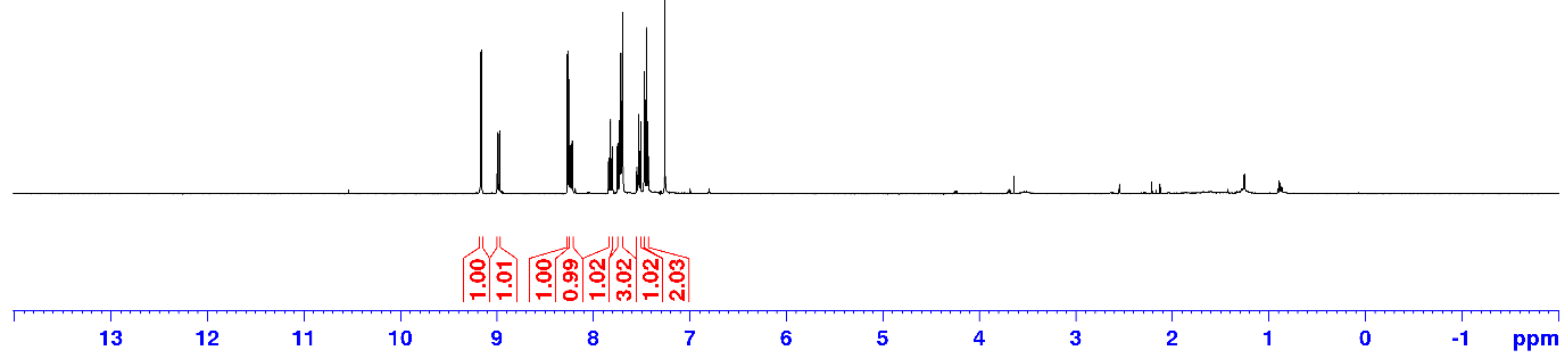

${ }^{13} \mathrm{C}$ NMR, $126 \mathrm{MHz}, \mathrm{CDCl}_{3}$

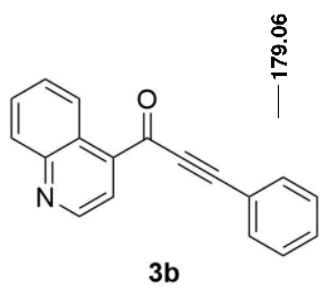

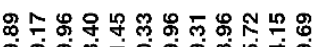

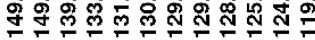

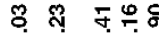

的

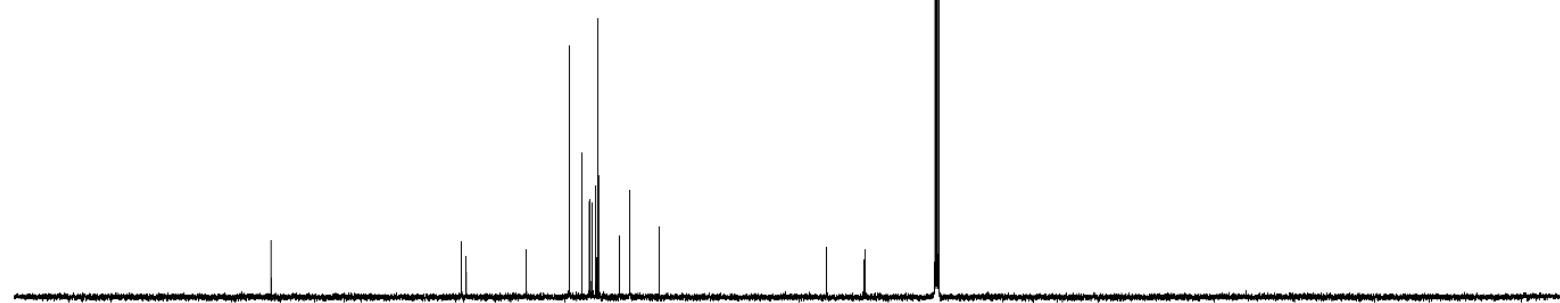

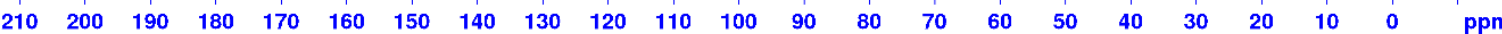


${ }^{1} \mathrm{H} \mathrm{NMR}, 500 \mathrm{MHz}, \mathrm{CDCl}_{3}$

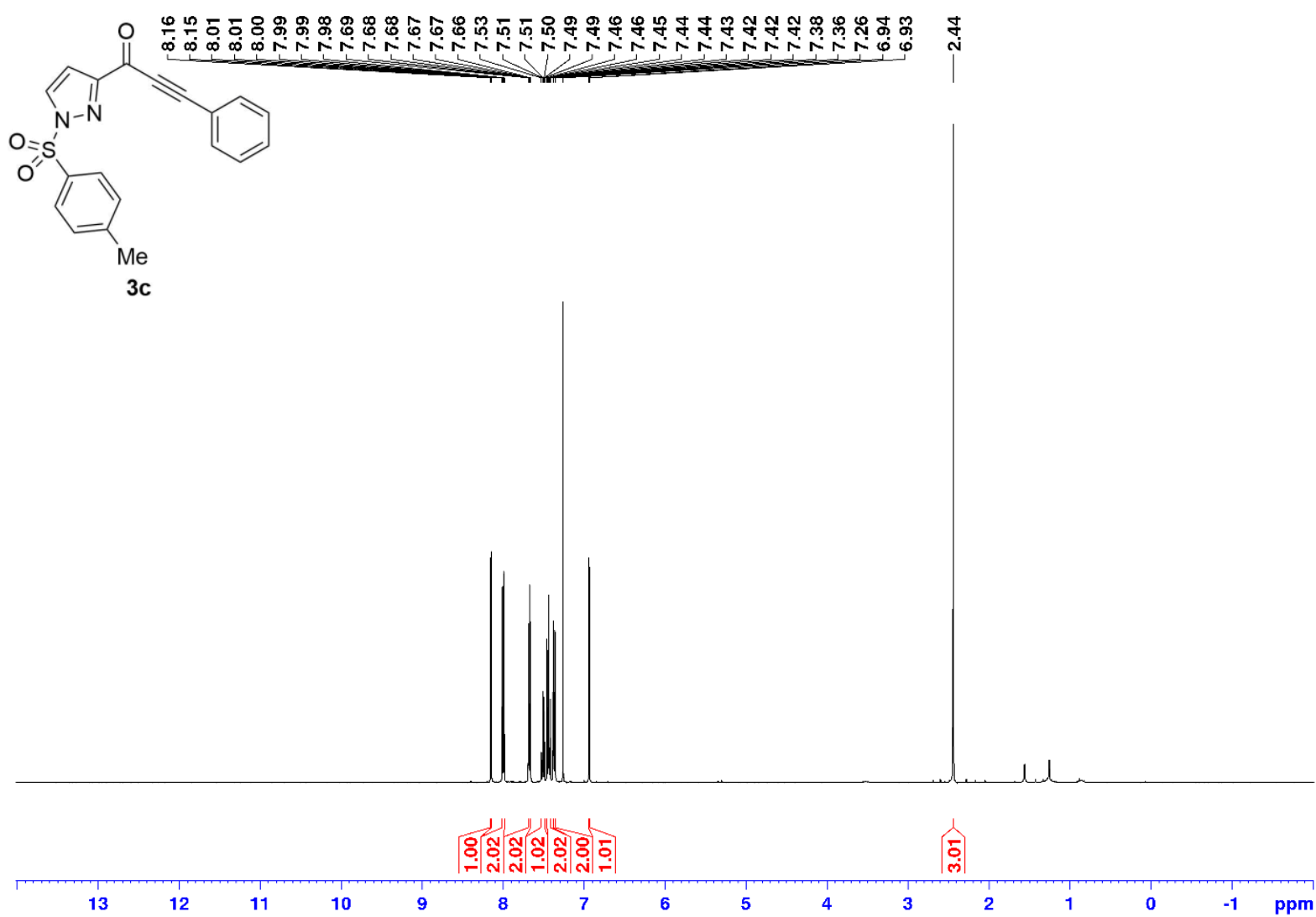

${ }^{13} \mathrm{C} \mathrm{NMR}, 126 \mathrm{MHz}, \mathrm{CDCl}_{3}$

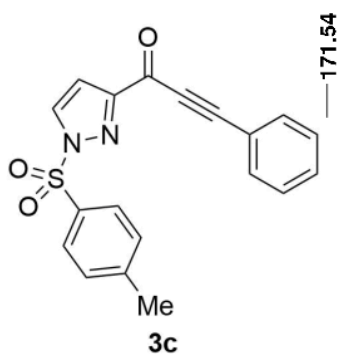

จุ

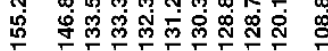

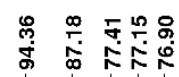

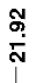

$3 c$

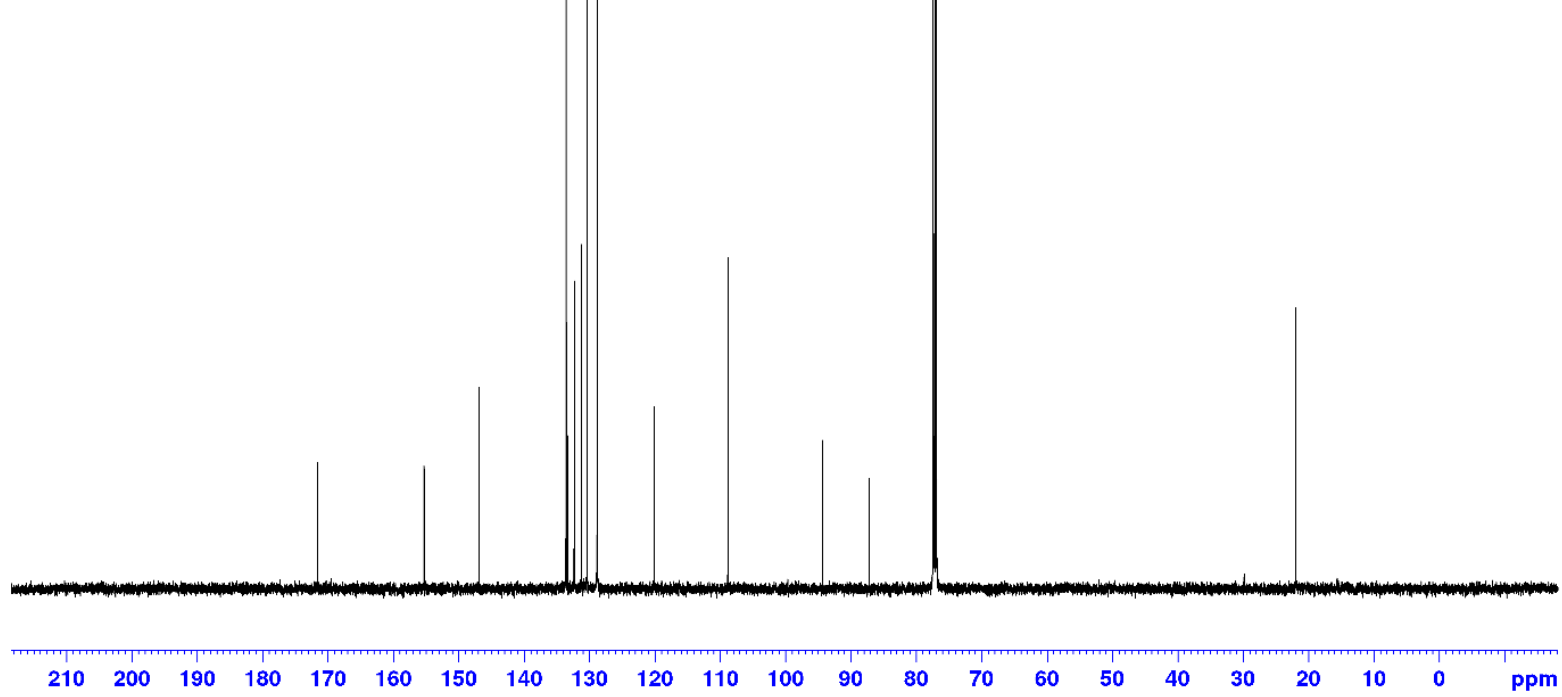


${ }^{1} \mathrm{H} \mathrm{NMR}, 500 \mathrm{MHz}, \mathrm{CDCl}_{3}$

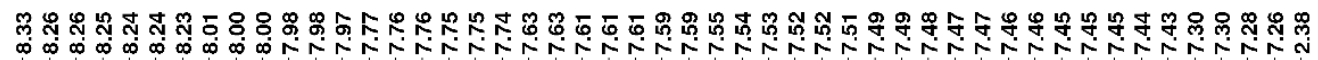

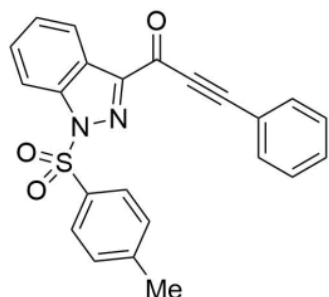

$3 d$

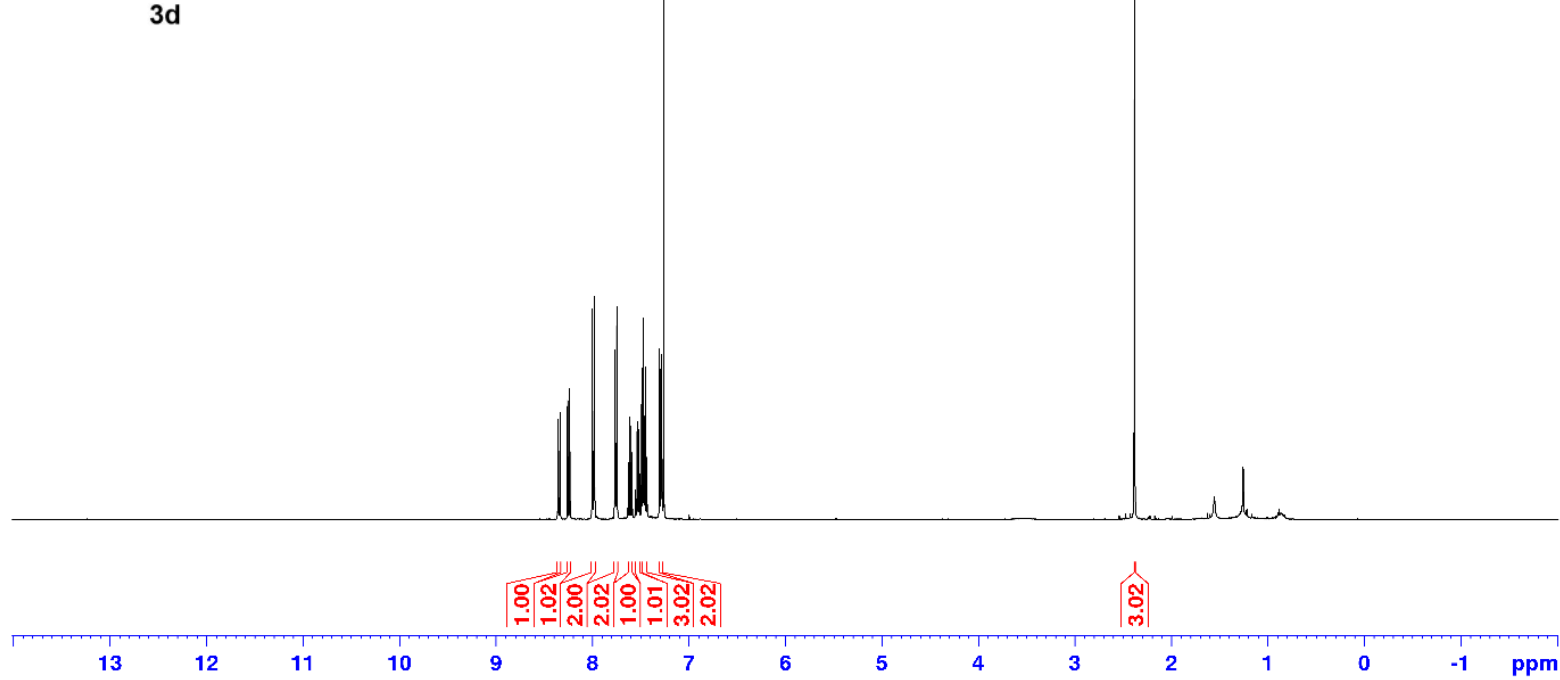

${ }^{13} \mathrm{C}$ NMR, $126 \mathrm{MHz}, \mathrm{CDCl}_{3}$

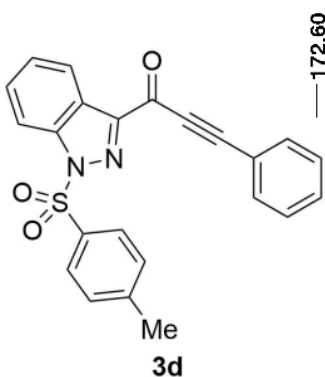

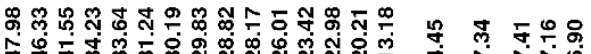

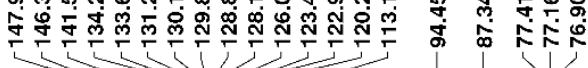

$\stackrel{\sim}{\stackrel{\sim}{\sim}}$

3d

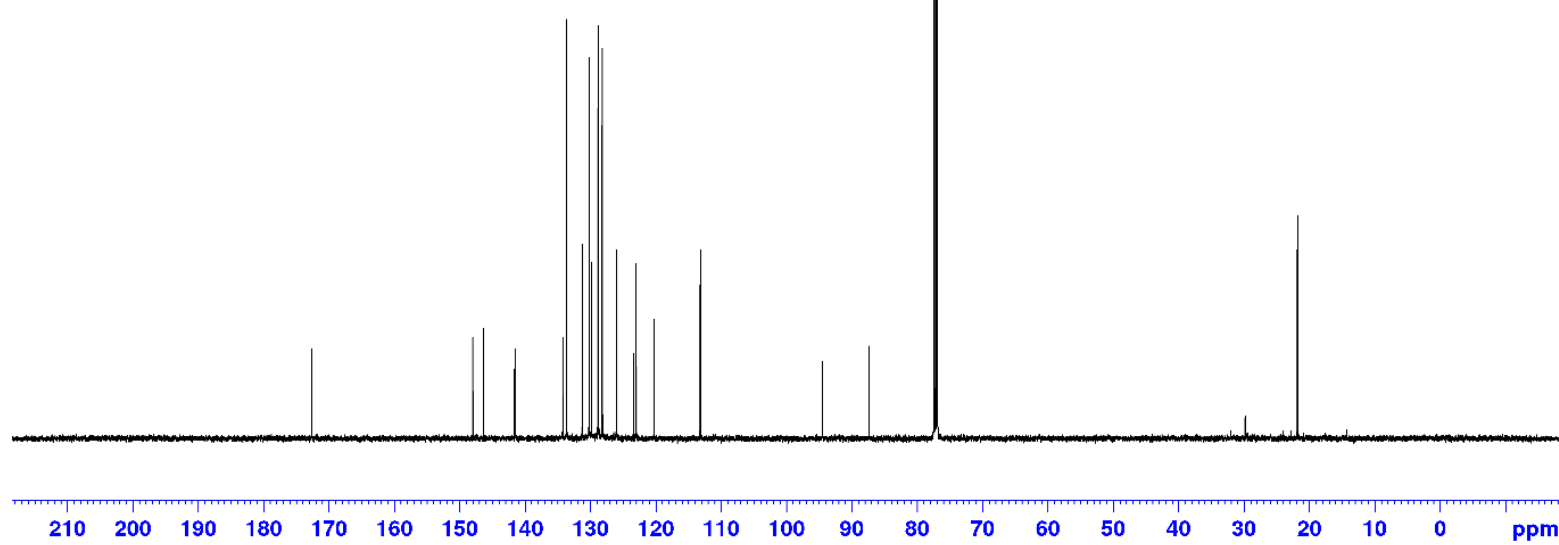


${ }^{1} \mathrm{H}$ NMR, $500 \mathrm{MHz}, \mathrm{CDCl}_{3}$

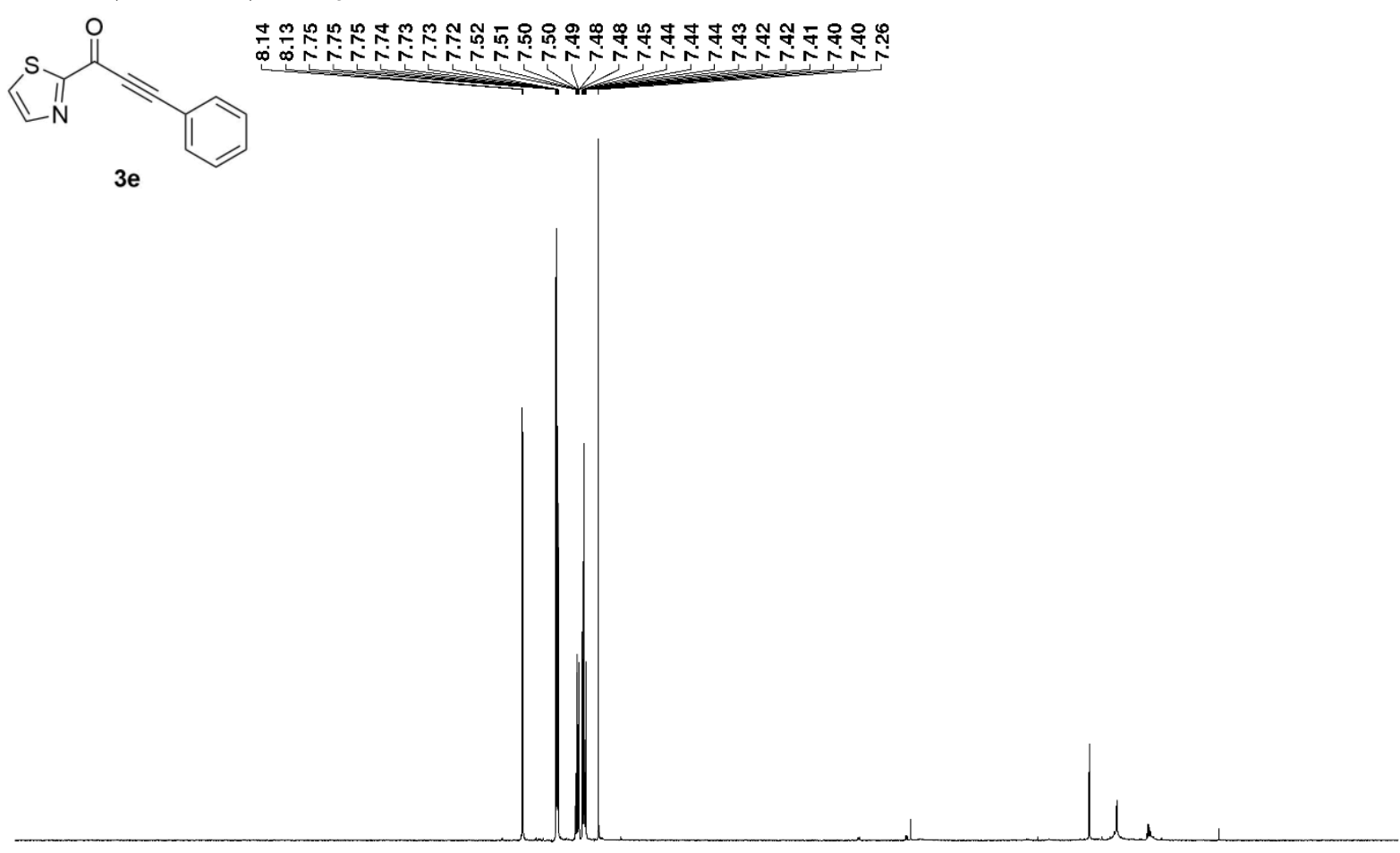

8 웅요.

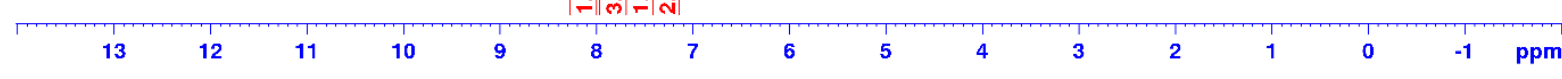

${ }^{13} \mathrm{C}$ NMR, $126 \mathrm{MHz}, \mathrm{CDCl}_{3}$

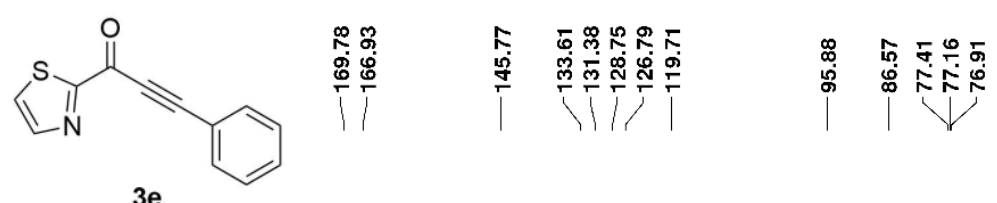

3e

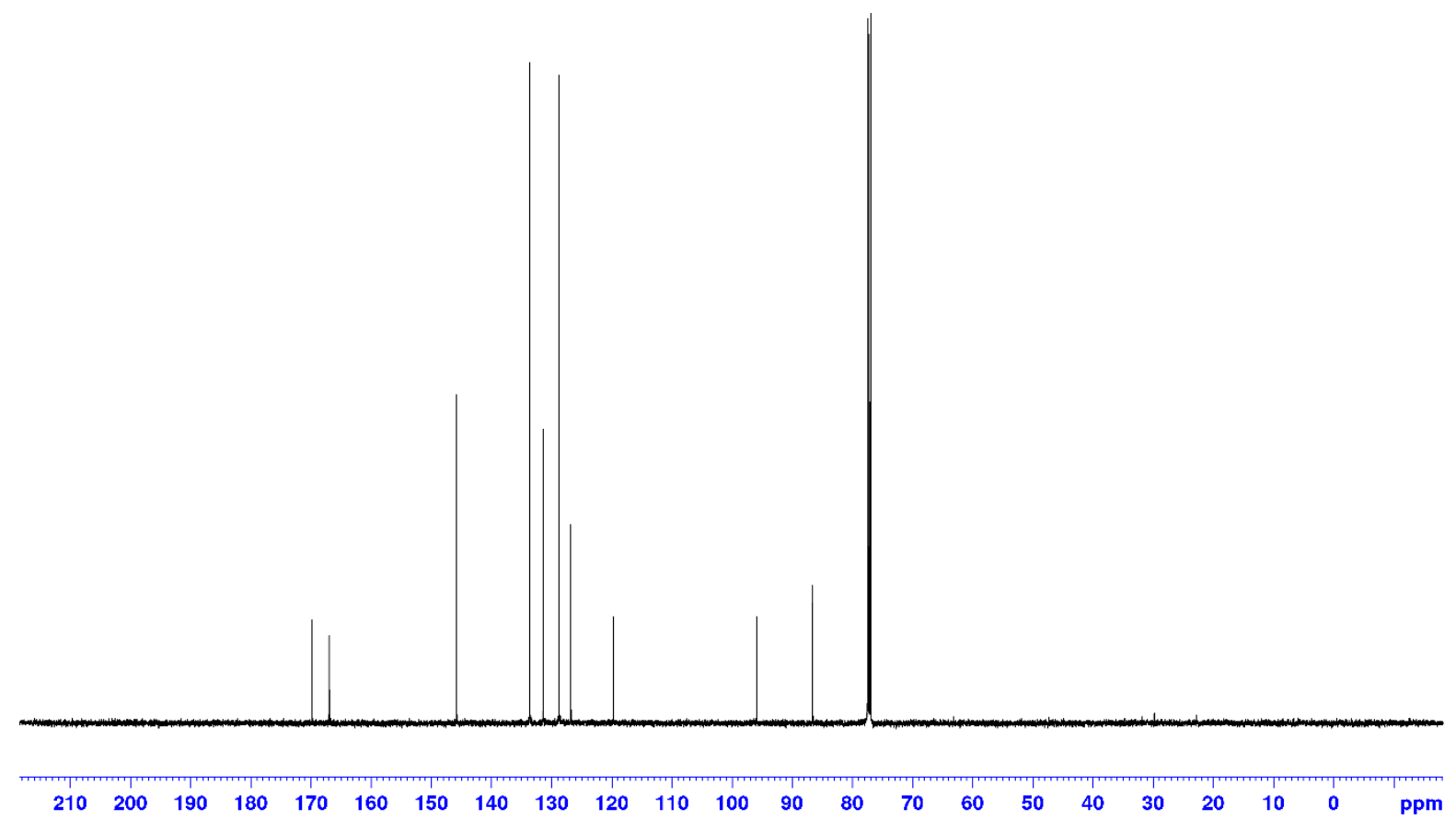


${ }^{1} \mathrm{H}$ NMR, $500 \mathrm{MHz}, \mathrm{CDCl}_{3}$
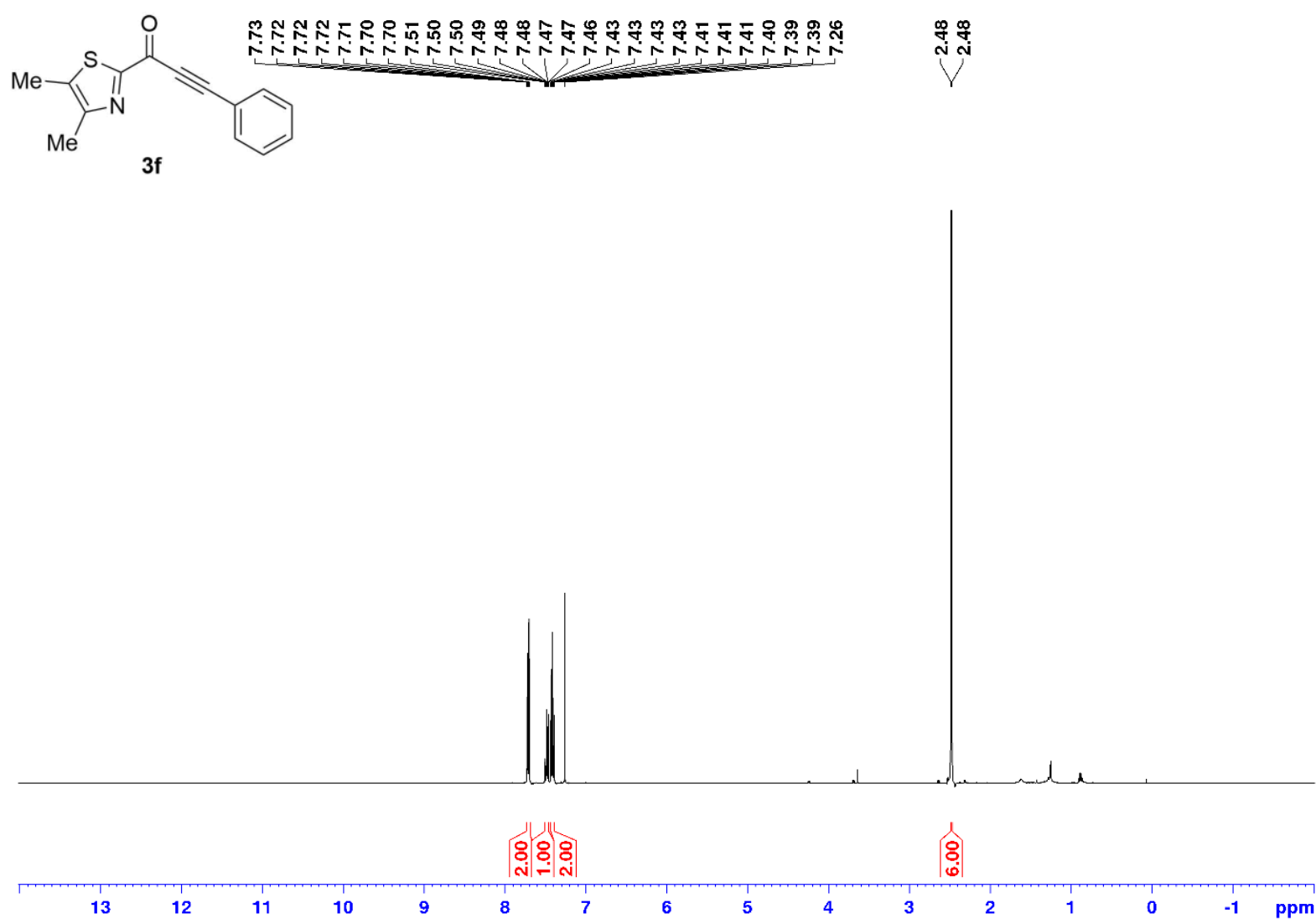

${ }^{13} \mathrm{C}$ NMR, $126 \mathrm{MHz}, \mathrm{CDCl}_{3}$

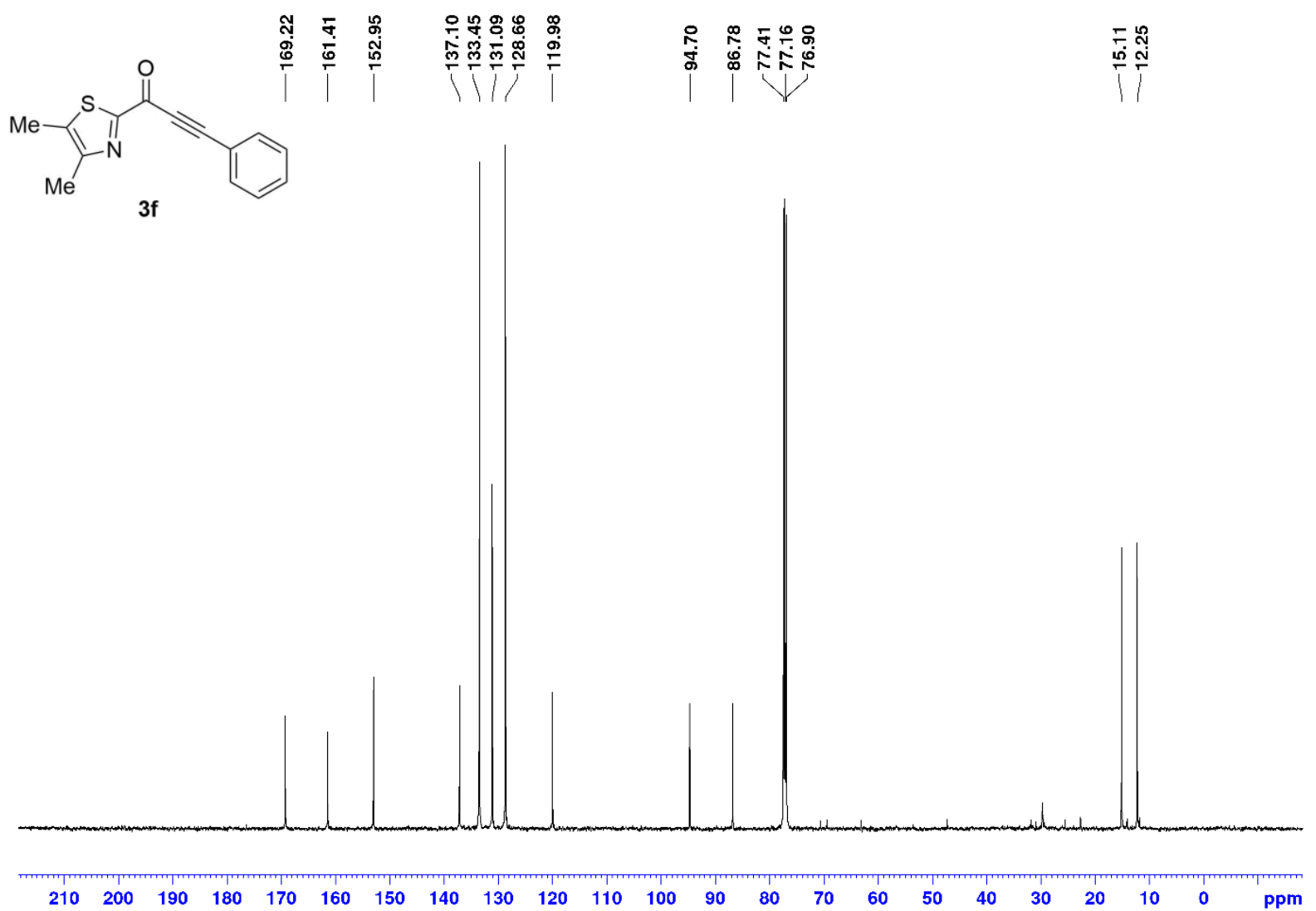


${ }^{1} \mathrm{H} \mathrm{NMR}, 500 \mathrm{MHz}, \mathrm{CDCl}_{3}$

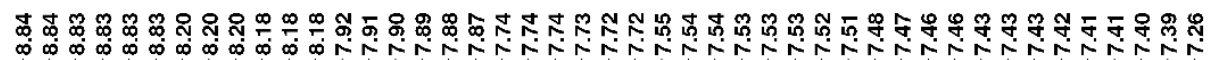

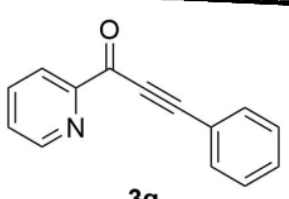

$3 g$

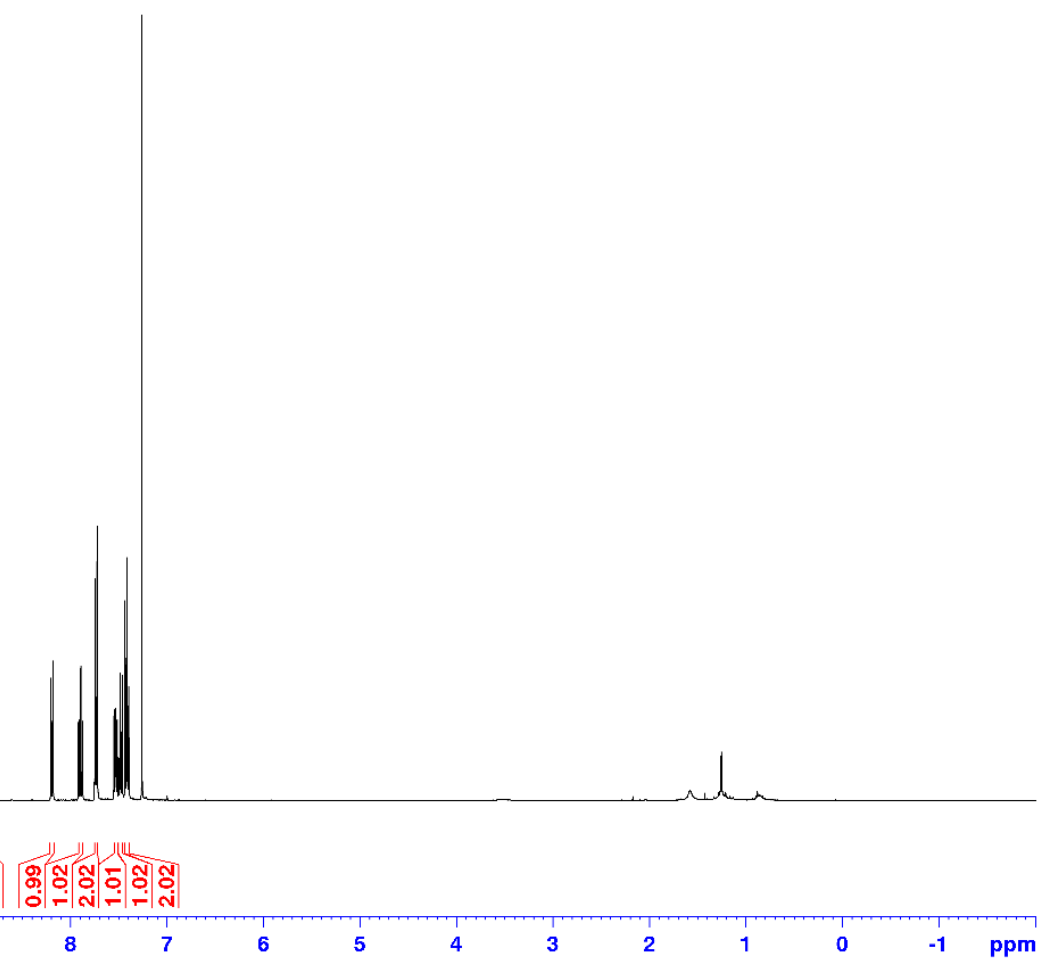

${ }^{13} \mathrm{C}$ NMR, $126 \mathrm{MHz}, \mathrm{CDCl}_{3}$

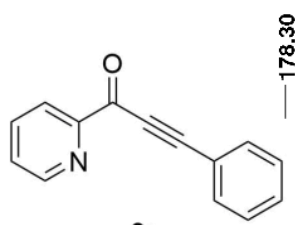

兽

1 रॉ广

草

$3 g$

i

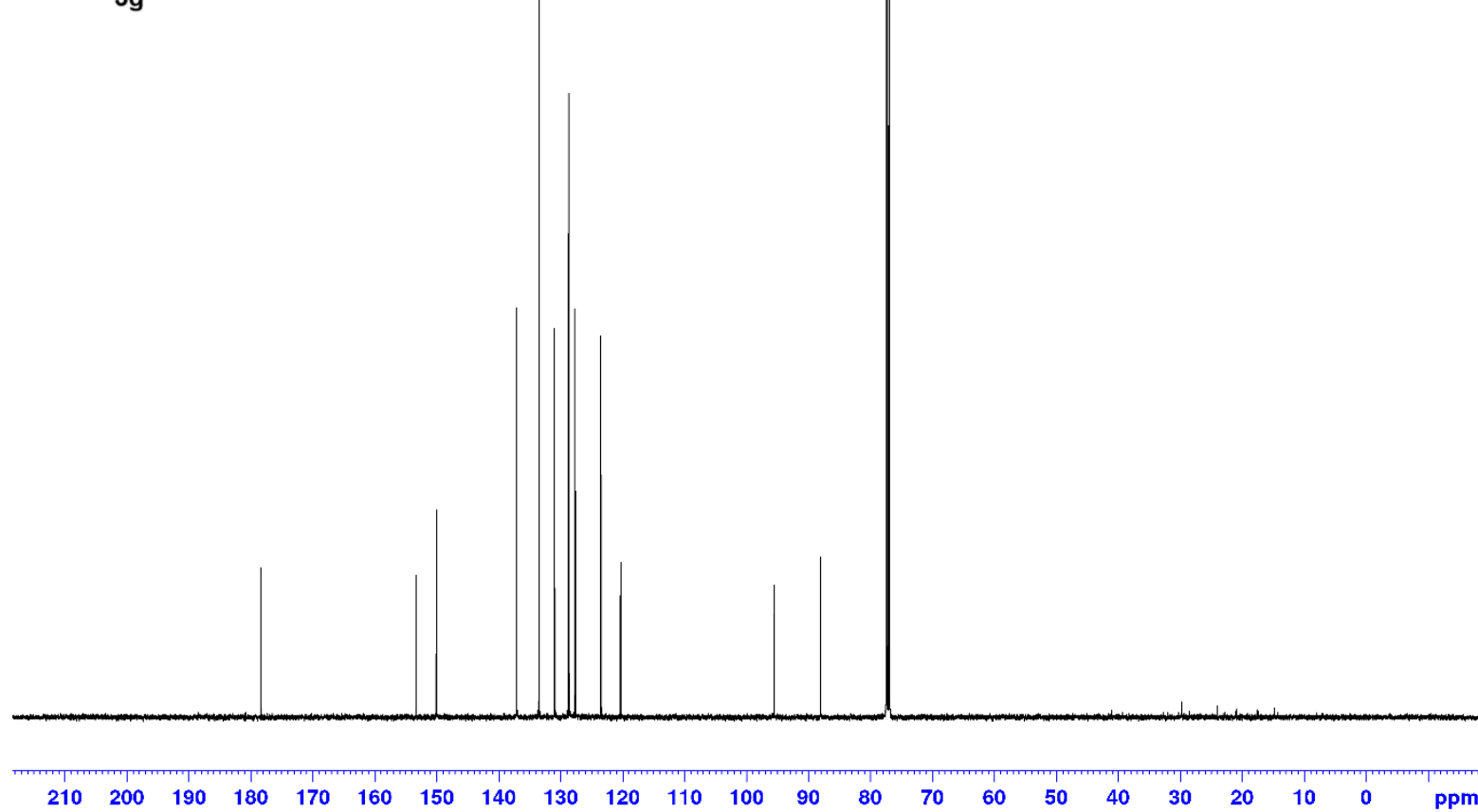


${ }^{1} \mathrm{H} \mathrm{NMR}, 500 \mathrm{MHz}, \mathrm{CDCl}_{3}$

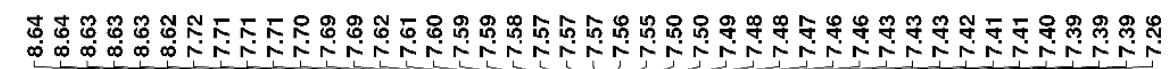<smiles>O=C(C#Cc1ccccc1)c1ncccc1F</smiles>

$3 \mathrm{~h}$

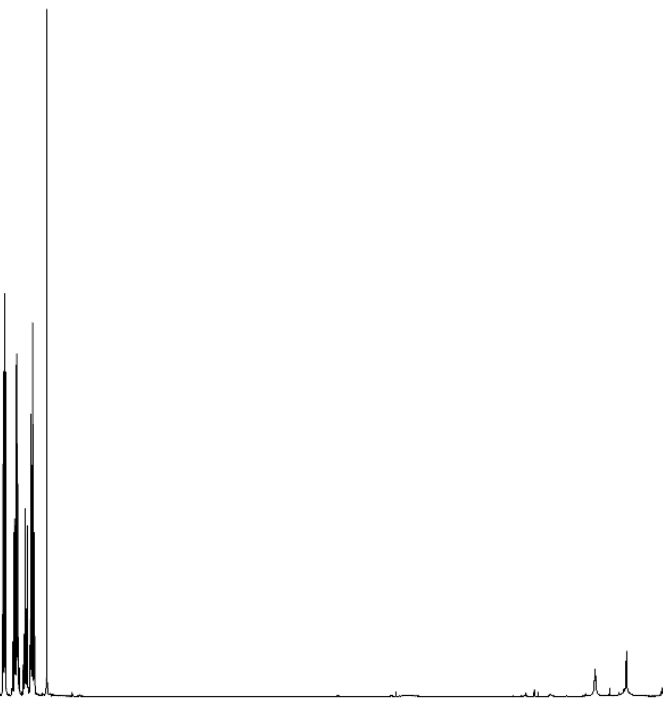

8.

${ }^{13} \mathrm{C}$ NMR, $126 \mathrm{MHz}, \mathrm{CDCl}_{3}$

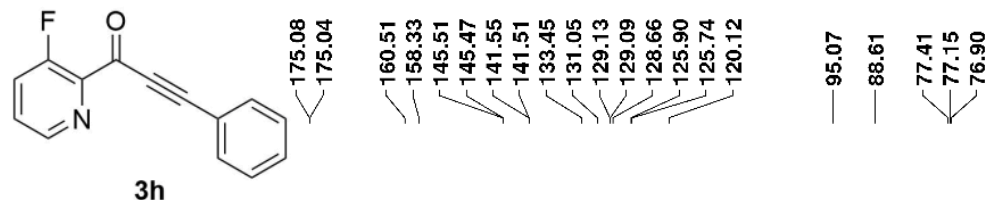

$3 \mathrm{~h}$

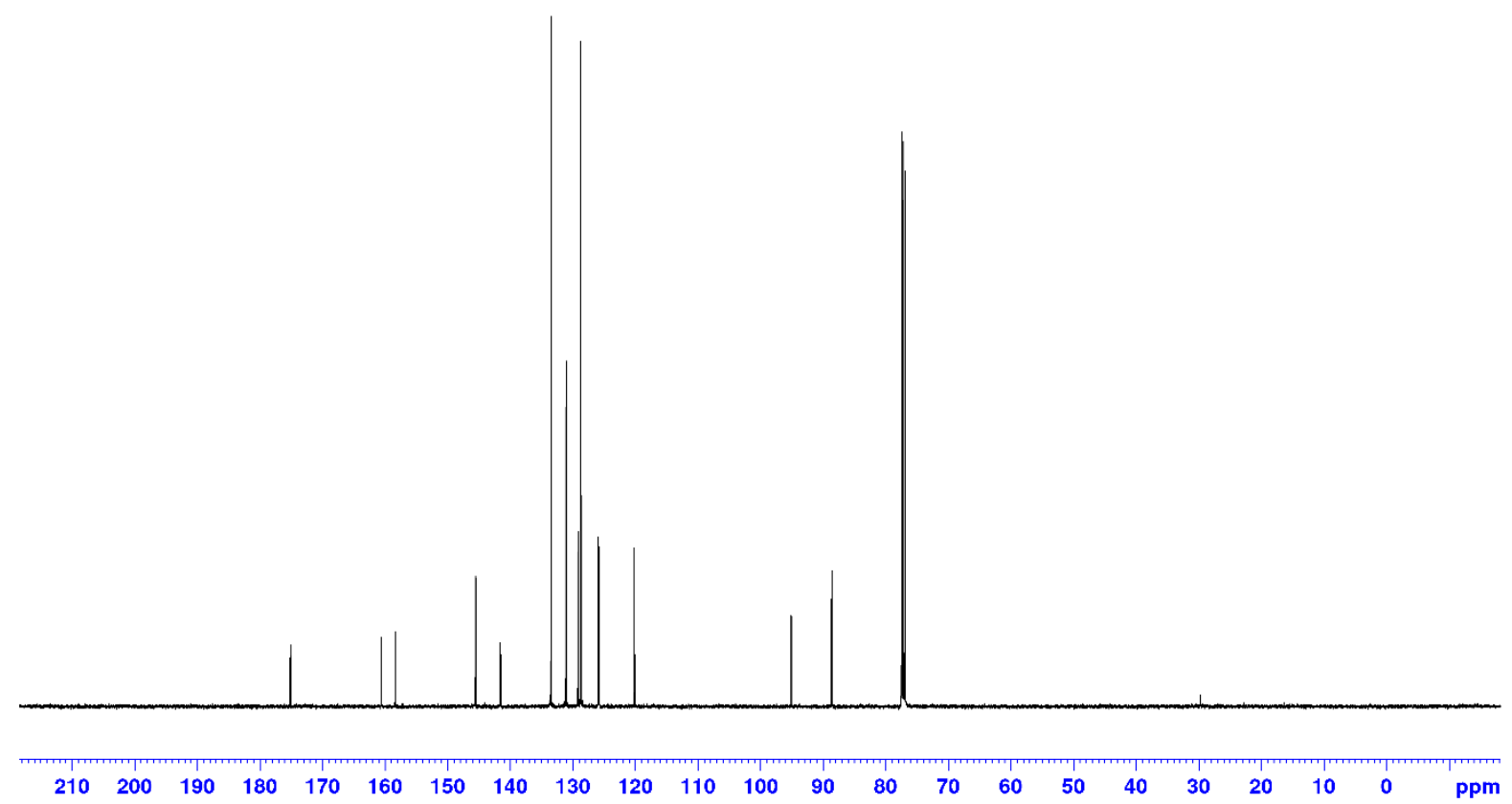


${ }^{19} \mathrm{~F}$ NMR, $471 \mathrm{MHz}, \mathrm{CDCl}_{3}$

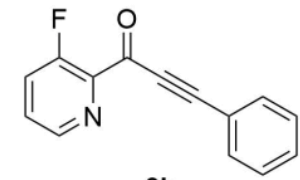

$3 \mathrm{~h}$

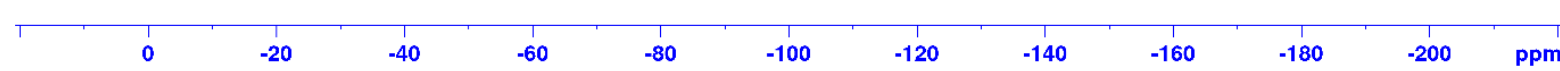

${ }^{1} \mathrm{H} \mathrm{NMR}, 500 \mathrm{MHz}, \mathrm{CDCl}_{3}$
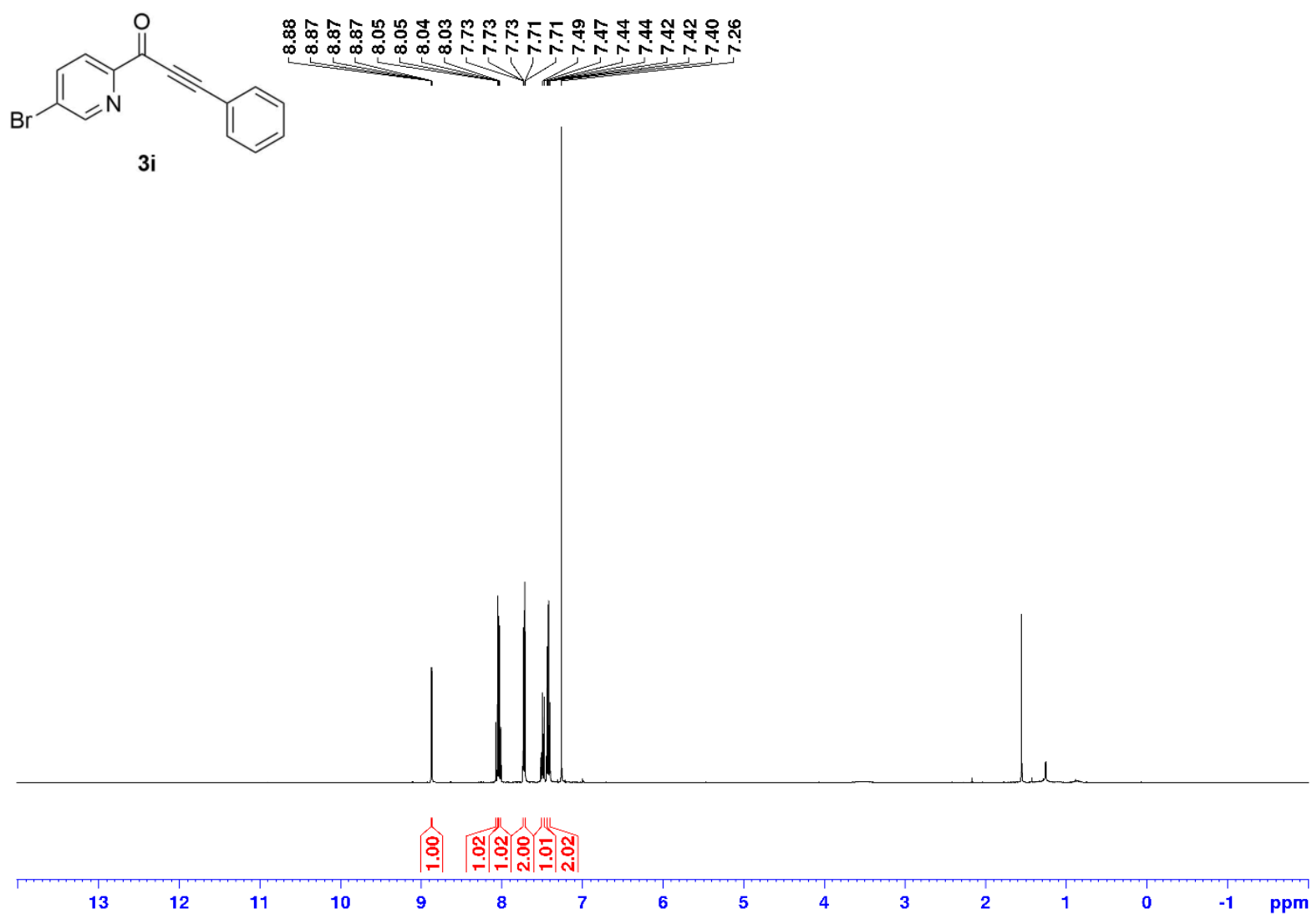
${ }^{13} \mathrm{C} \mathrm{NMR}, 126 \mathrm{MHz}, \mathrm{CDCl}_{3}$<smiles>O=C(C#Cc1ccccc1)c1ccc(Br)cn1</smiles>

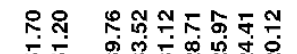

它

$3 \mathrm{i}$

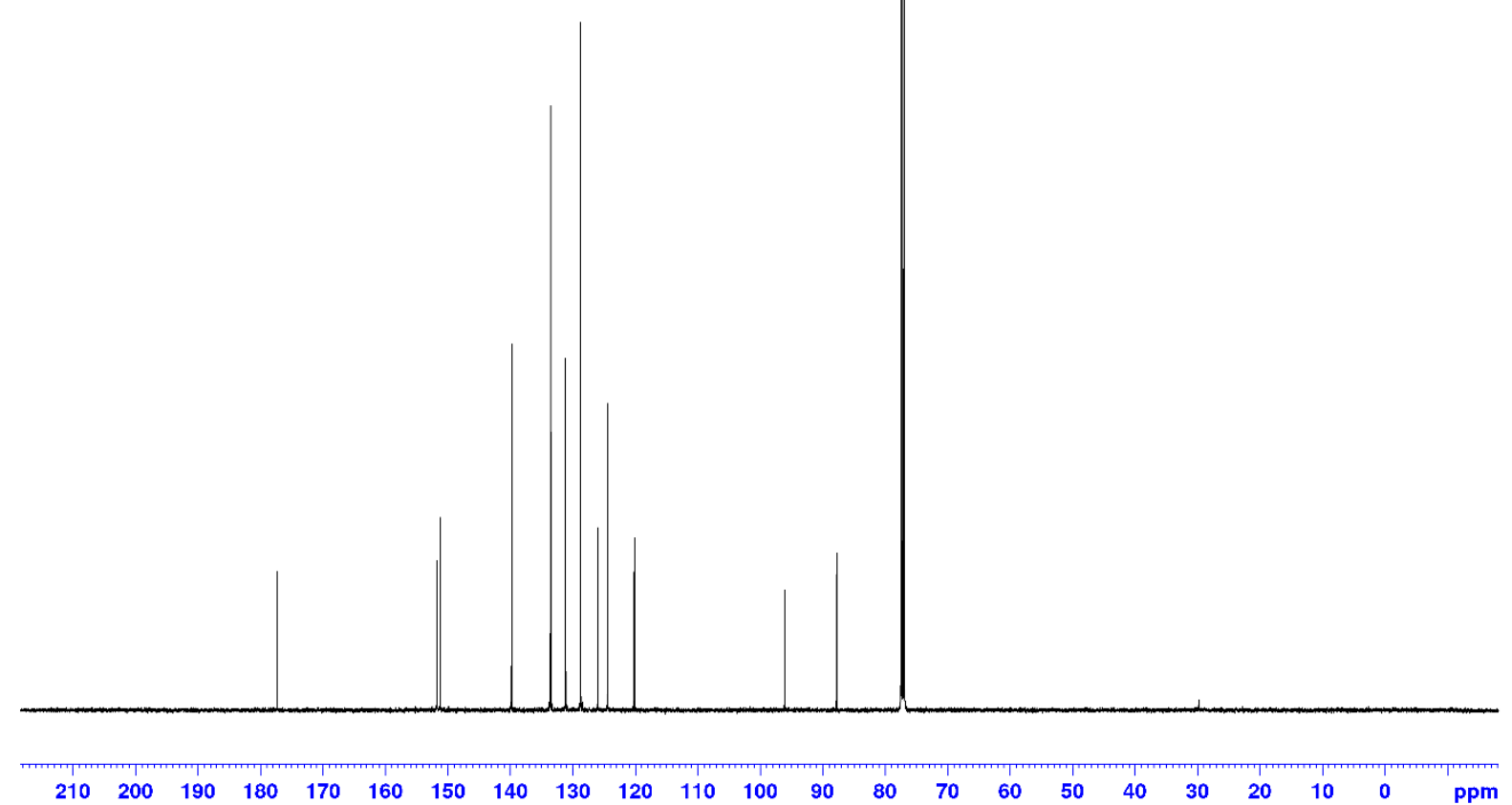

${ }^{1} \mathrm{H} \mathrm{NMR}, 500 \mathrm{MHz}, \mathrm{CDCl}_{3}$

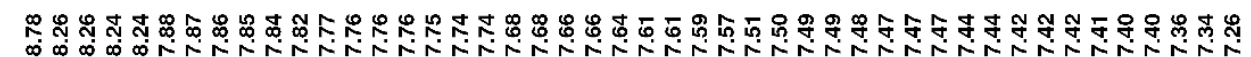<smiles>O=C(C#Cc1ccccc1)c1ccc(-c2ccccc2C(F)(F)F)cn1</smiles>

$|+|$ 
${ }^{13} \mathrm{C} \mathrm{NMR}, 126 \mathrm{MHz}, \mathrm{CDCl}_{3}$

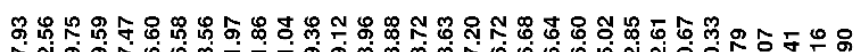

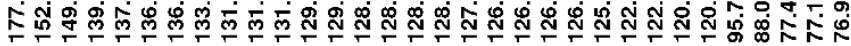<smiles>O=C(C#Cc1ccccc1)c1ccc(-c2ccccc2C(F)(F)F)cn1</smiles>

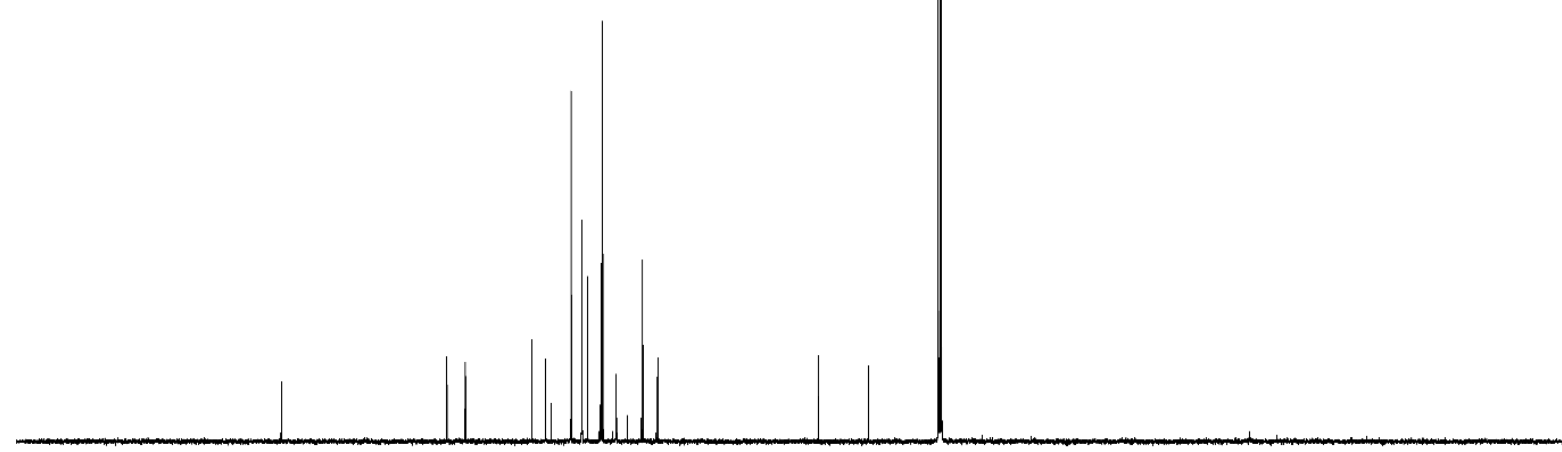

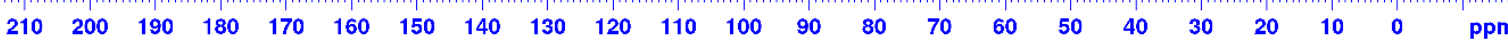

${ }^{19} \mathrm{~F}$ NMR, $471 \mathrm{MHz}, \mathrm{CDCl}_{3}$

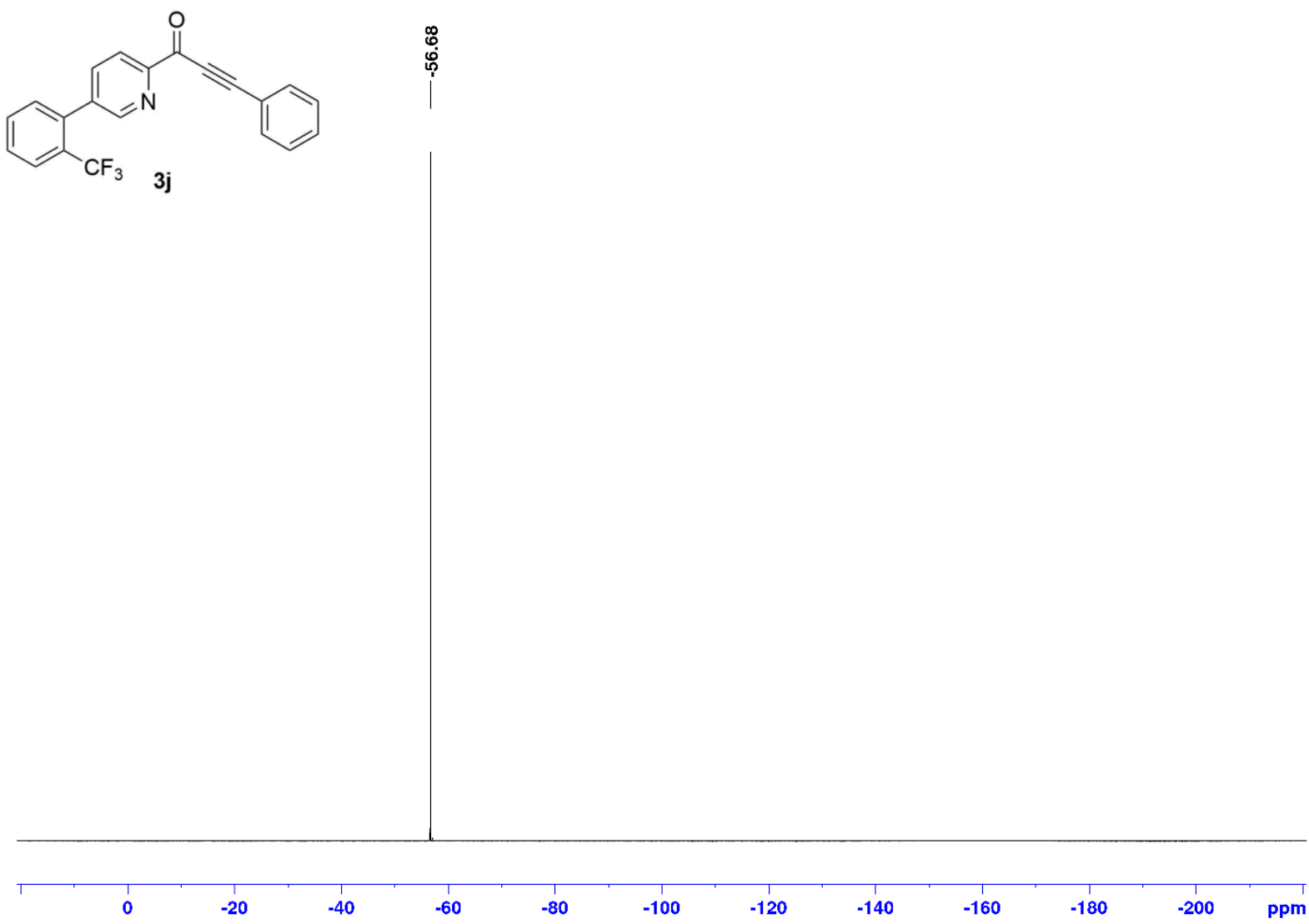


${ }^{1} \mathrm{H} \mathrm{NMR}, 500 \mathrm{MHz}, \mathrm{CDCl}_{3}$

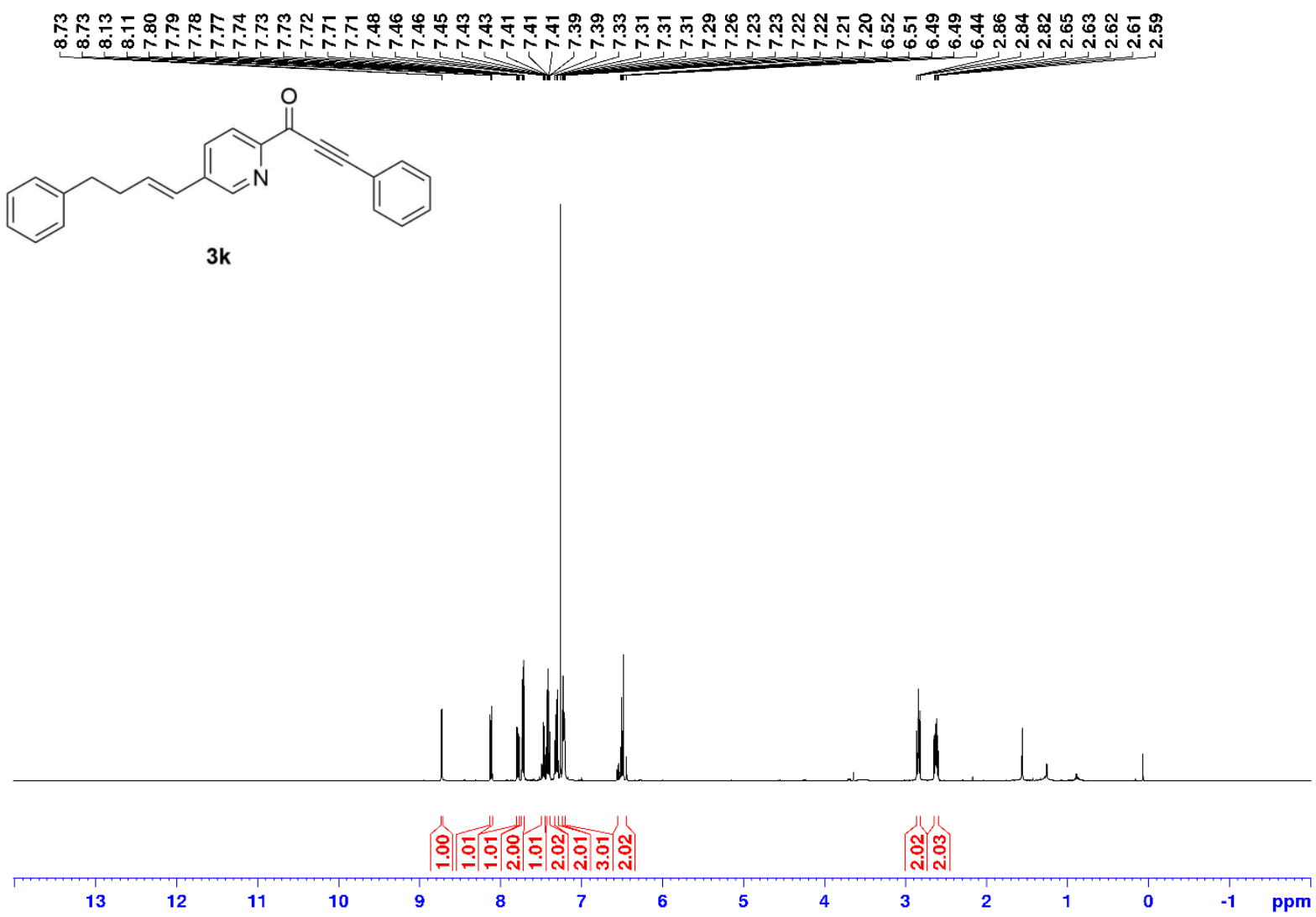

${ }^{13} \mathrm{C} \mathrm{NMR}, 126 \mathrm{MHz}, \mathrm{CDCl}_{3}$

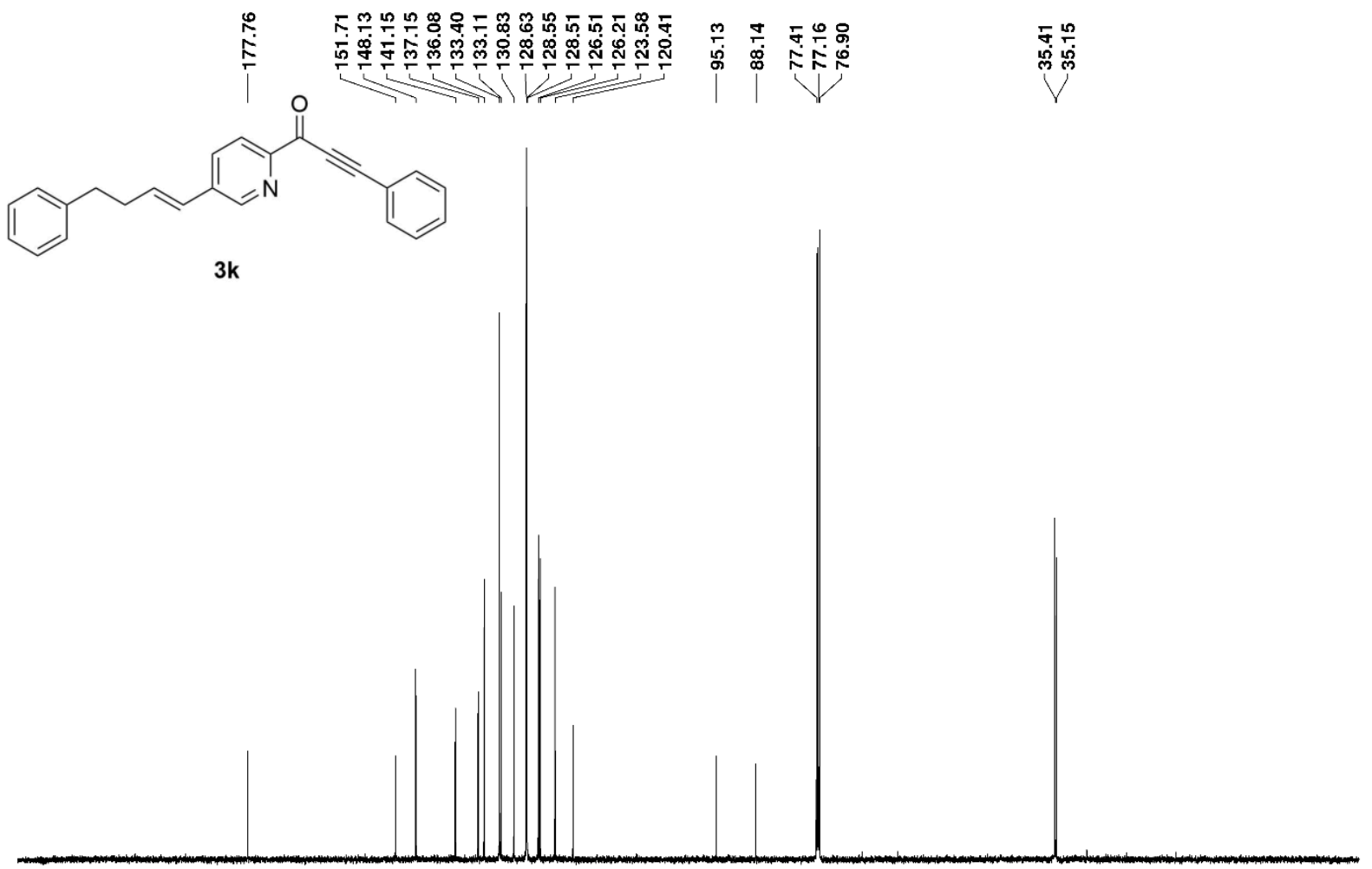

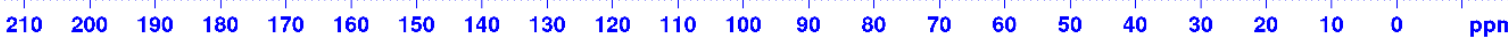


${ }^{1} \mathrm{H} \mathrm{NMR}, 500 \mathrm{MHz}, \mathrm{CDCl}_{3}$

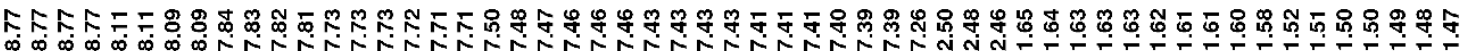

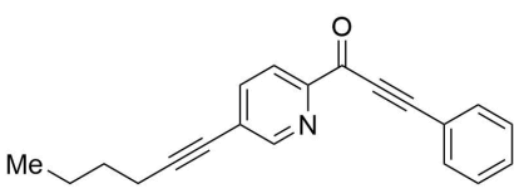

3!

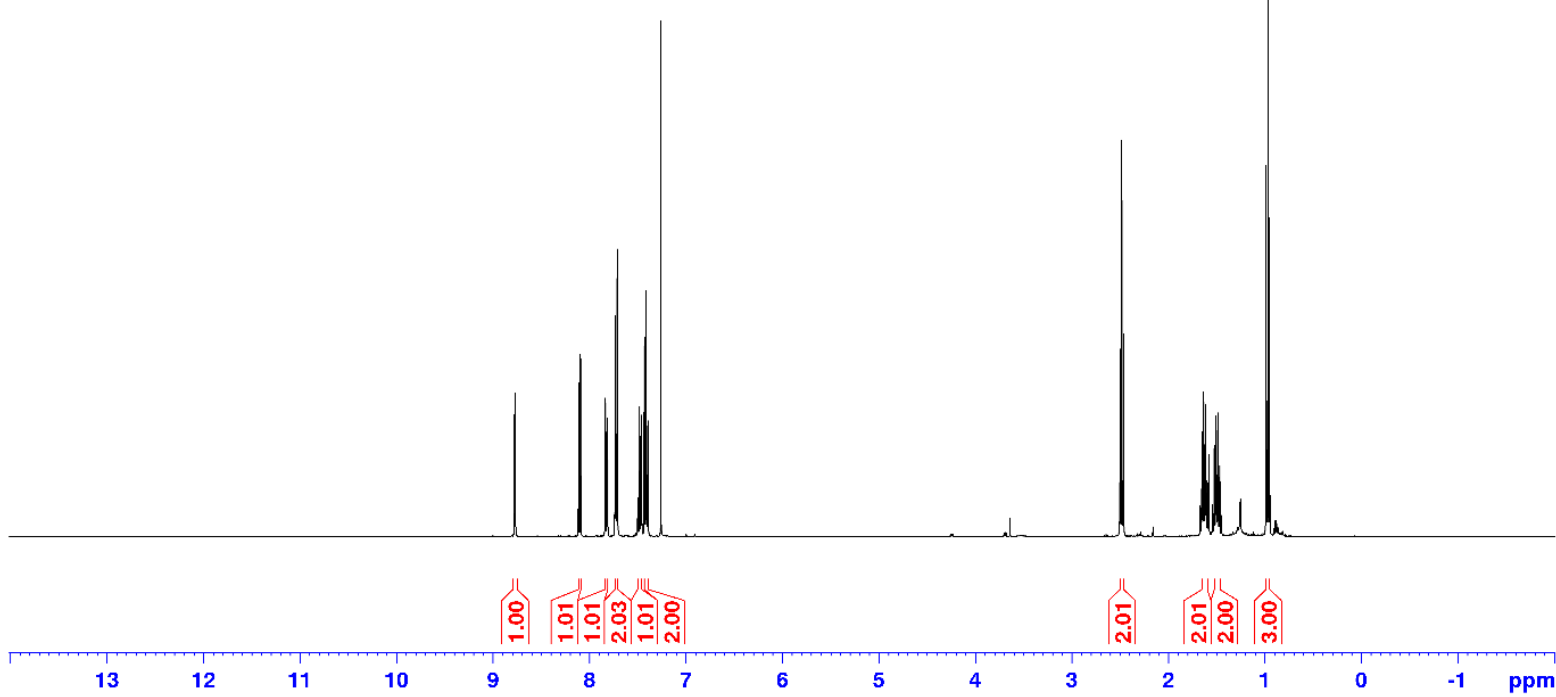

${ }^{13} \mathrm{C} \mathrm{NMR}, 126 \mathrm{MHz}, \mathrm{CDCl}_{3}$
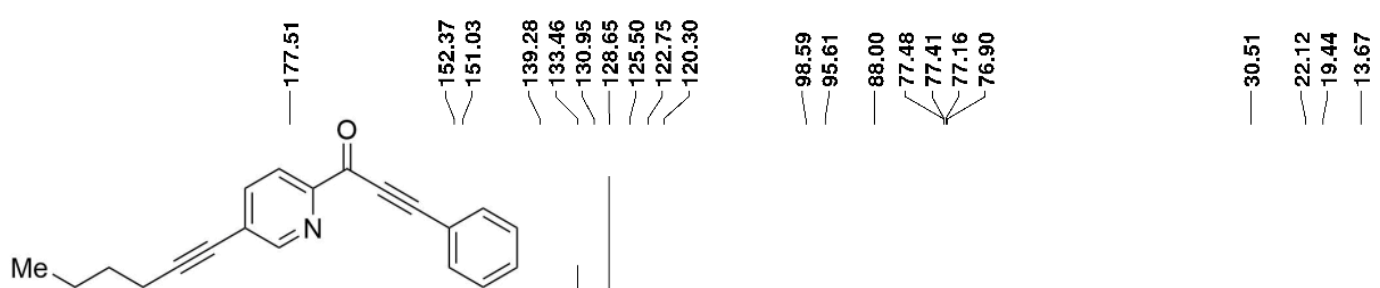

31

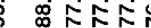

iิ

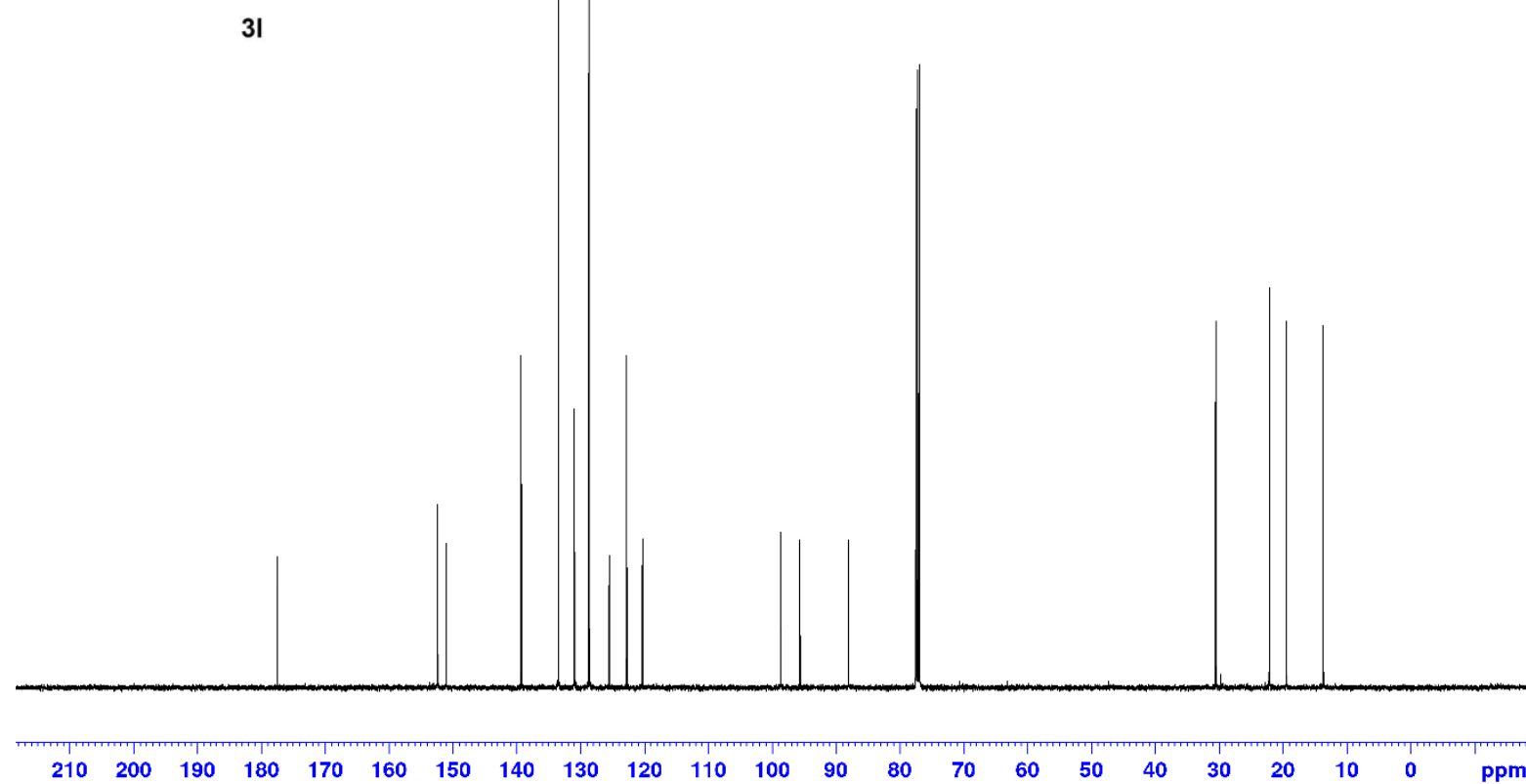


${ }^{1} \mathrm{H} \mathrm{NMR}, 500 \mathrm{MHz}, \mathrm{CDCl}_{3}$

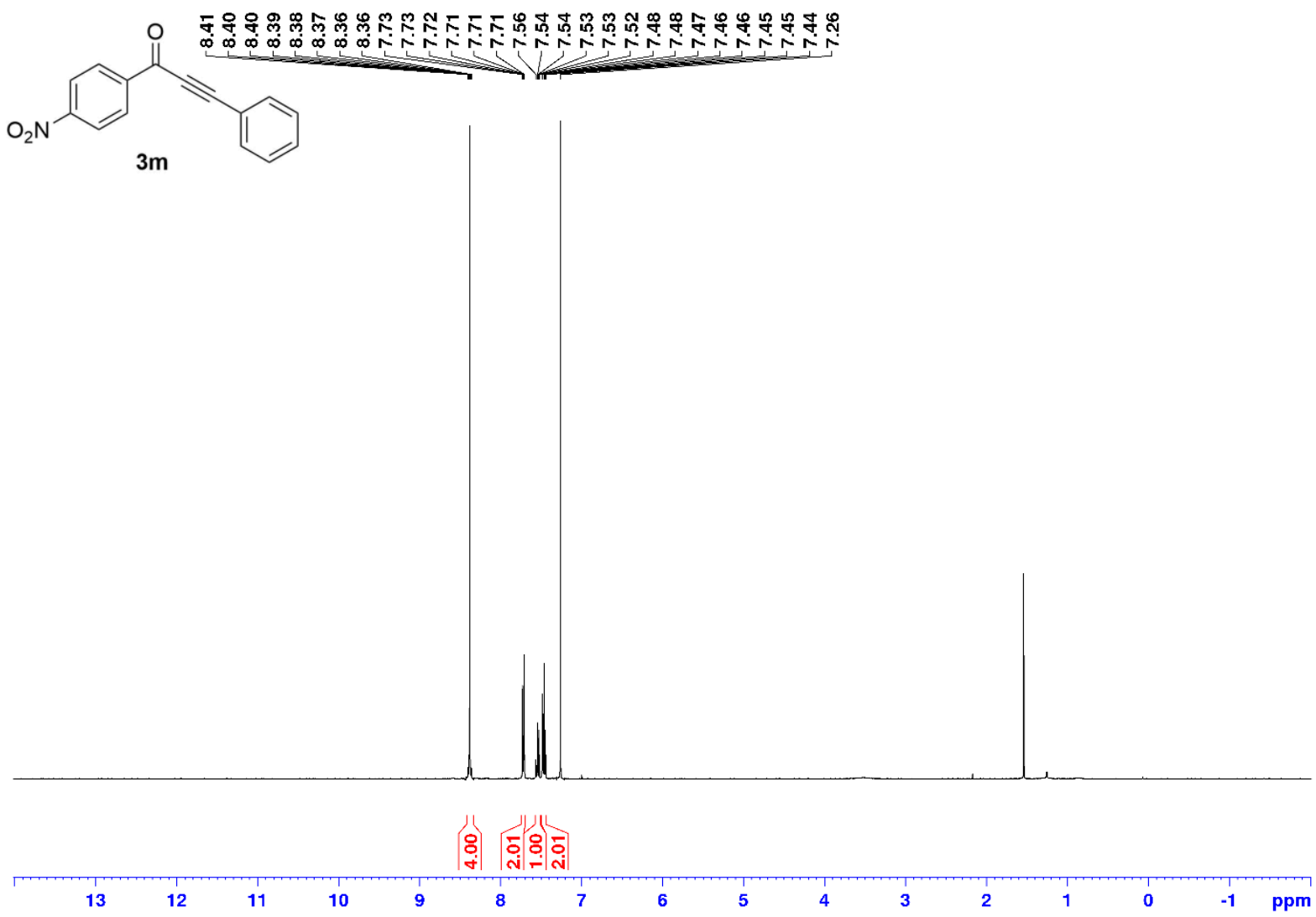

${ }^{13} \mathrm{C} \mathrm{NMR}, 126 \mathrm{MHz}, \mathrm{CDCl}_{3}$<smiles>O=C(C#Cc1ccccc1)c1ccc([N+](=O)[O-])cc1</smiles>

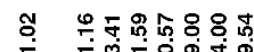

产 宁饫

象

|

$\mathrm{O}_{2} \mathrm{~N}$
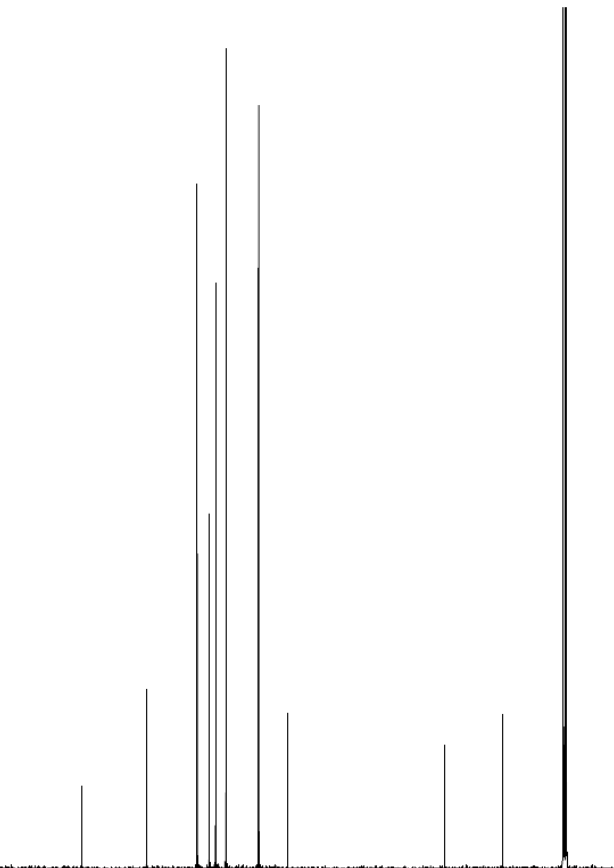

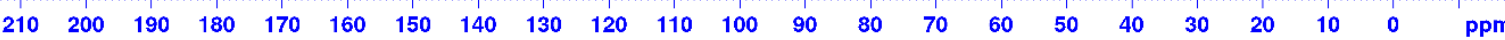


${ }^{1} \mathrm{H}$ NMR, $400 \mathrm{MHz}, \mathrm{CDCl}_{3}$

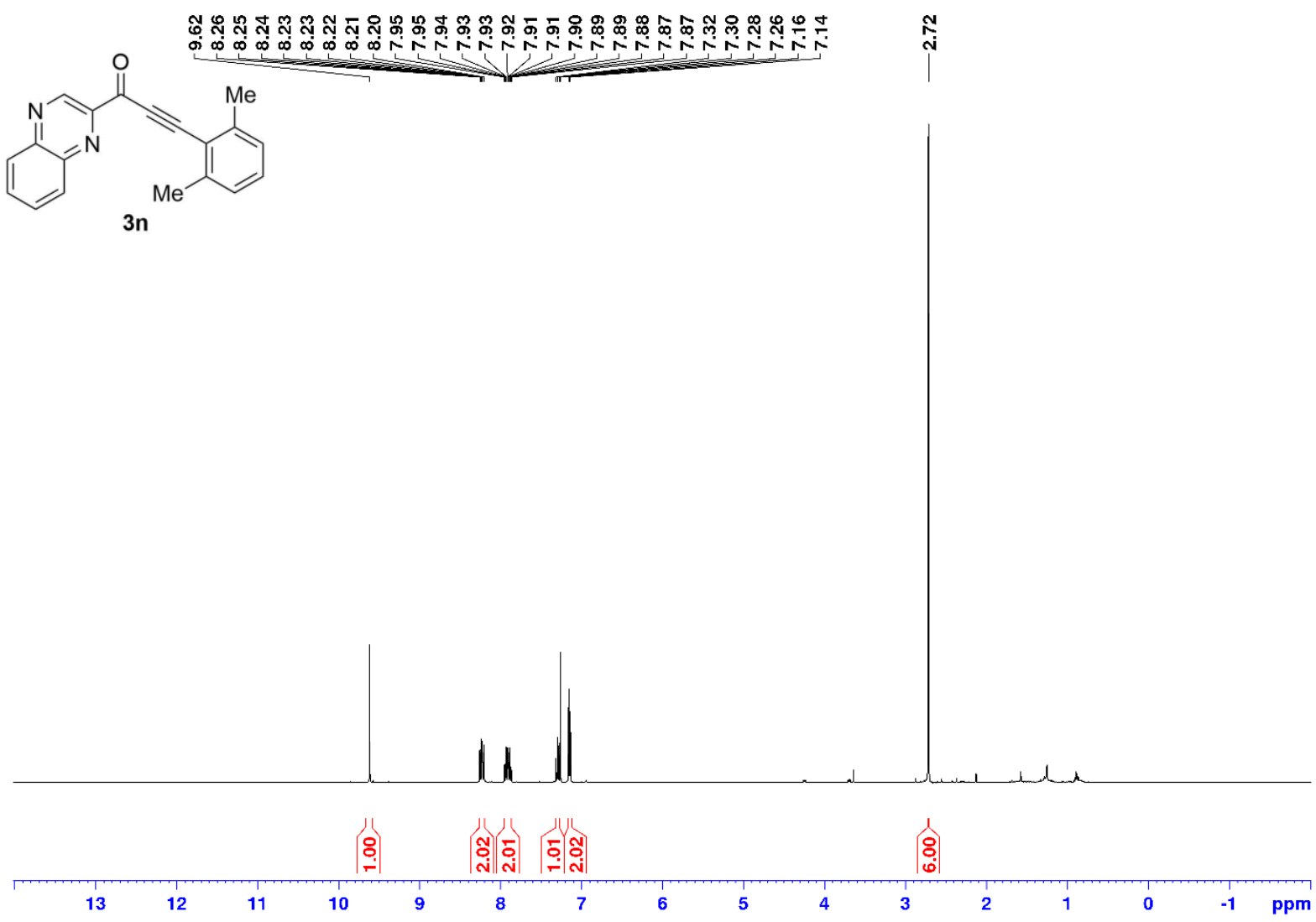

${ }^{13} \mathrm{C} \mathrm{NMR}, 126 \mathrm{MHz}, \mathrm{CDCl}_{3}$

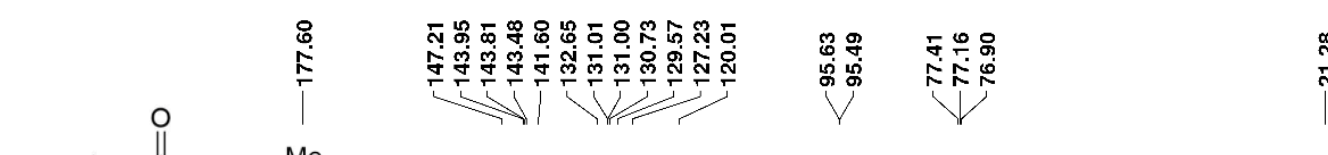<smiles>Cc1cccc(C)c1C#CC(=O)c1cnc2ccccc2n1</smiles>

3n

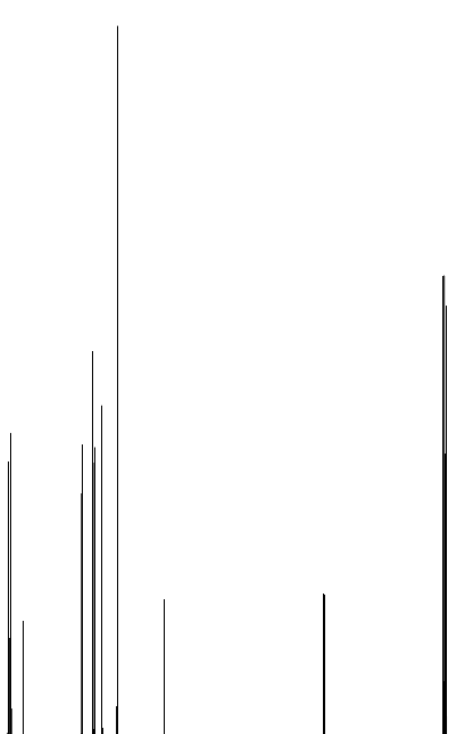

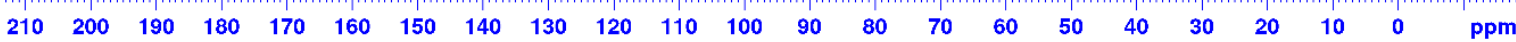


${ }^{1} \mathrm{H} \mathrm{NMR}, 400 \mathrm{MHz}, \mathrm{CDCl}_{3}$
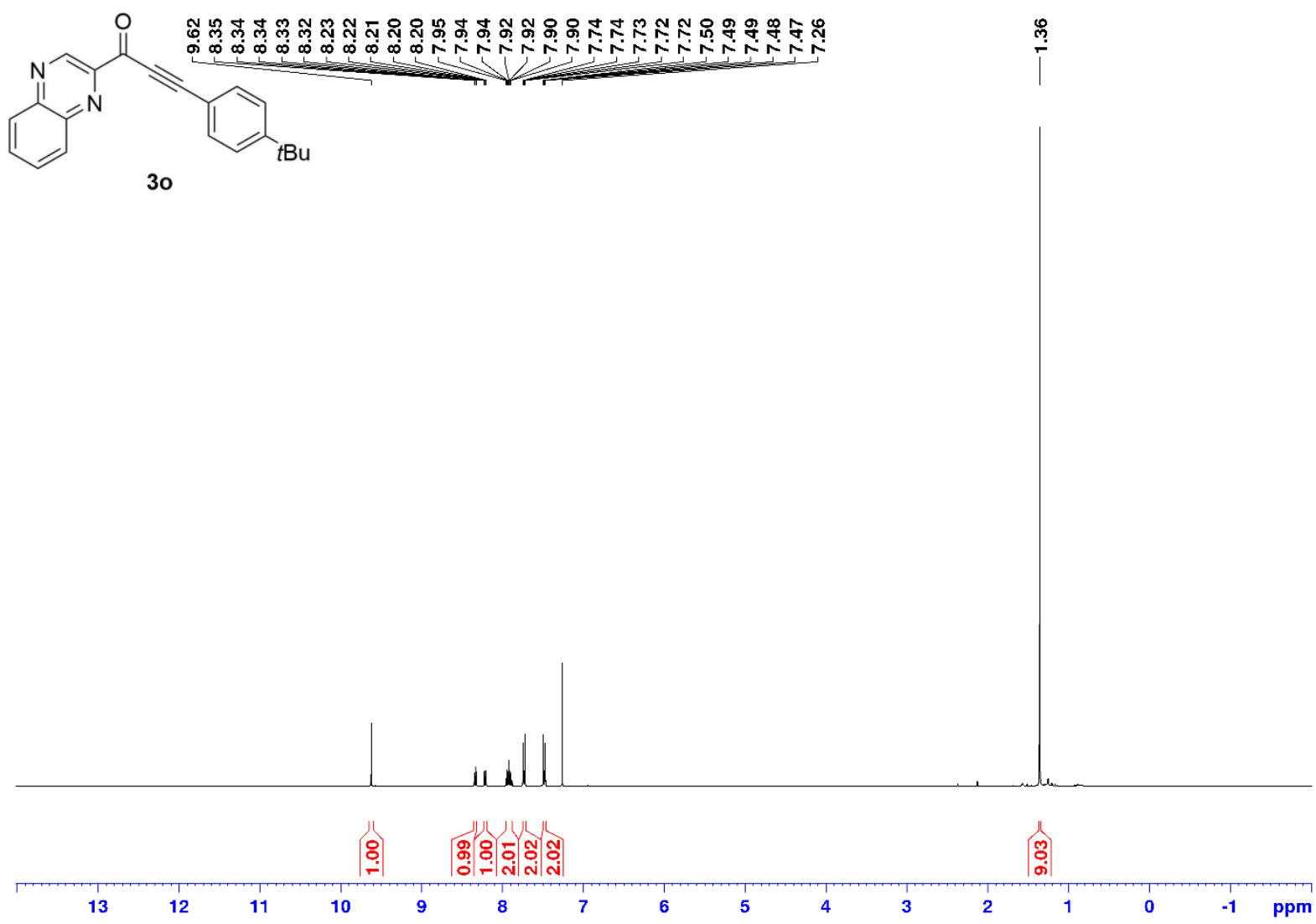

${ }^{13} \mathrm{C} \mathrm{NMR}, 126 \mathrm{MHz}, \mathrm{CDCl}_{3}$

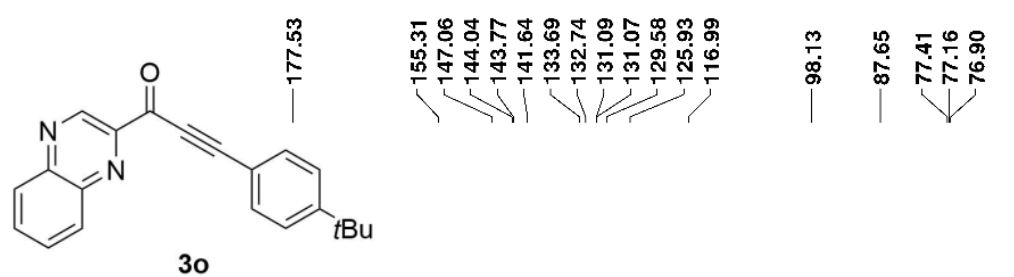

iึ

30

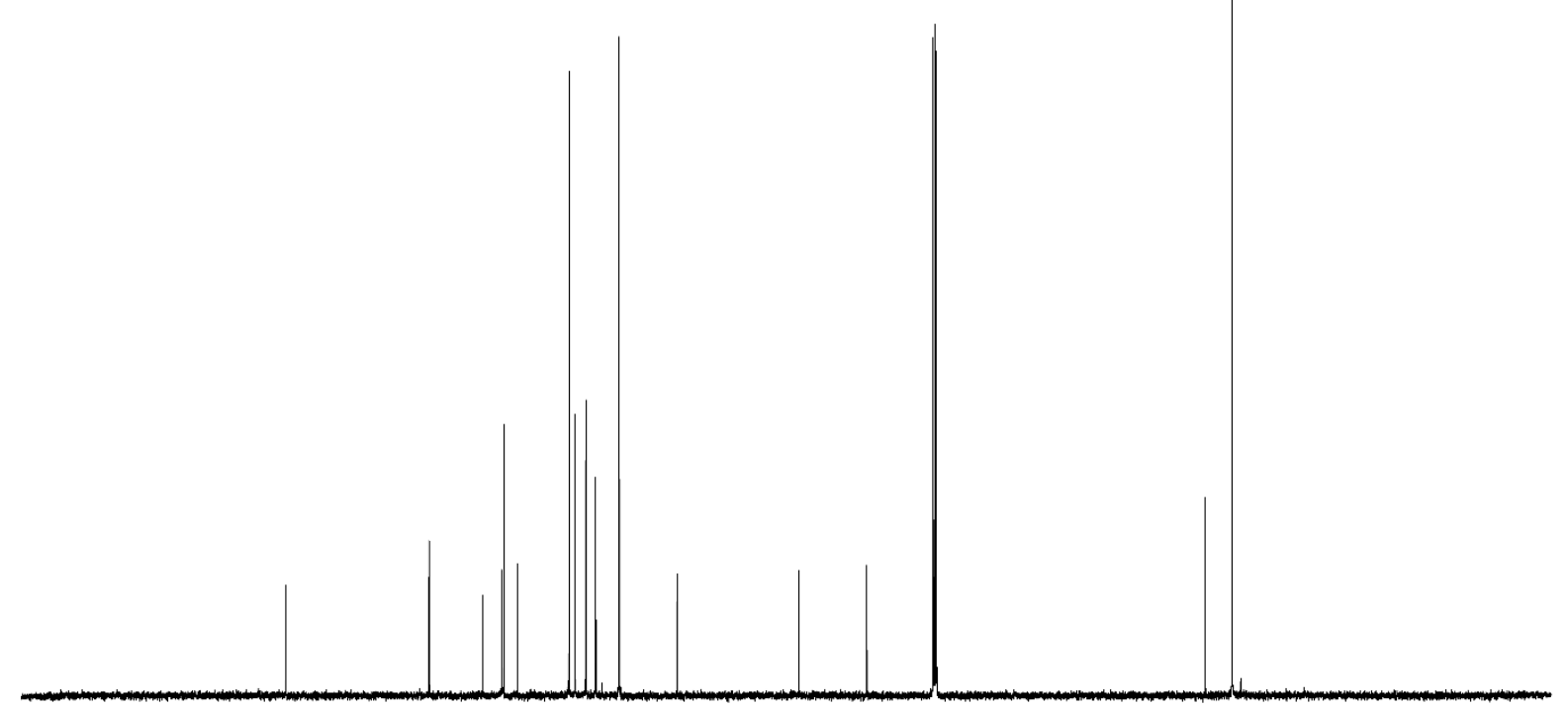

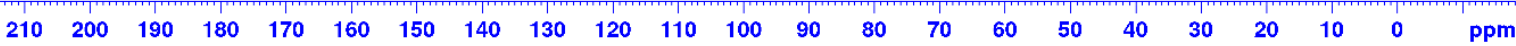


${ }^{1} \mathrm{H} \mathrm{NMR}, 400 \mathrm{MHz}, \mathrm{CDCl}_{3}$

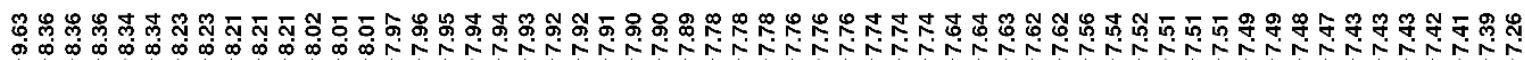<smiles>O=C(C#Cc1cccc(-c2ccccc2)c1)c1cnc2ccccc2n1</smiles>

$3 p$

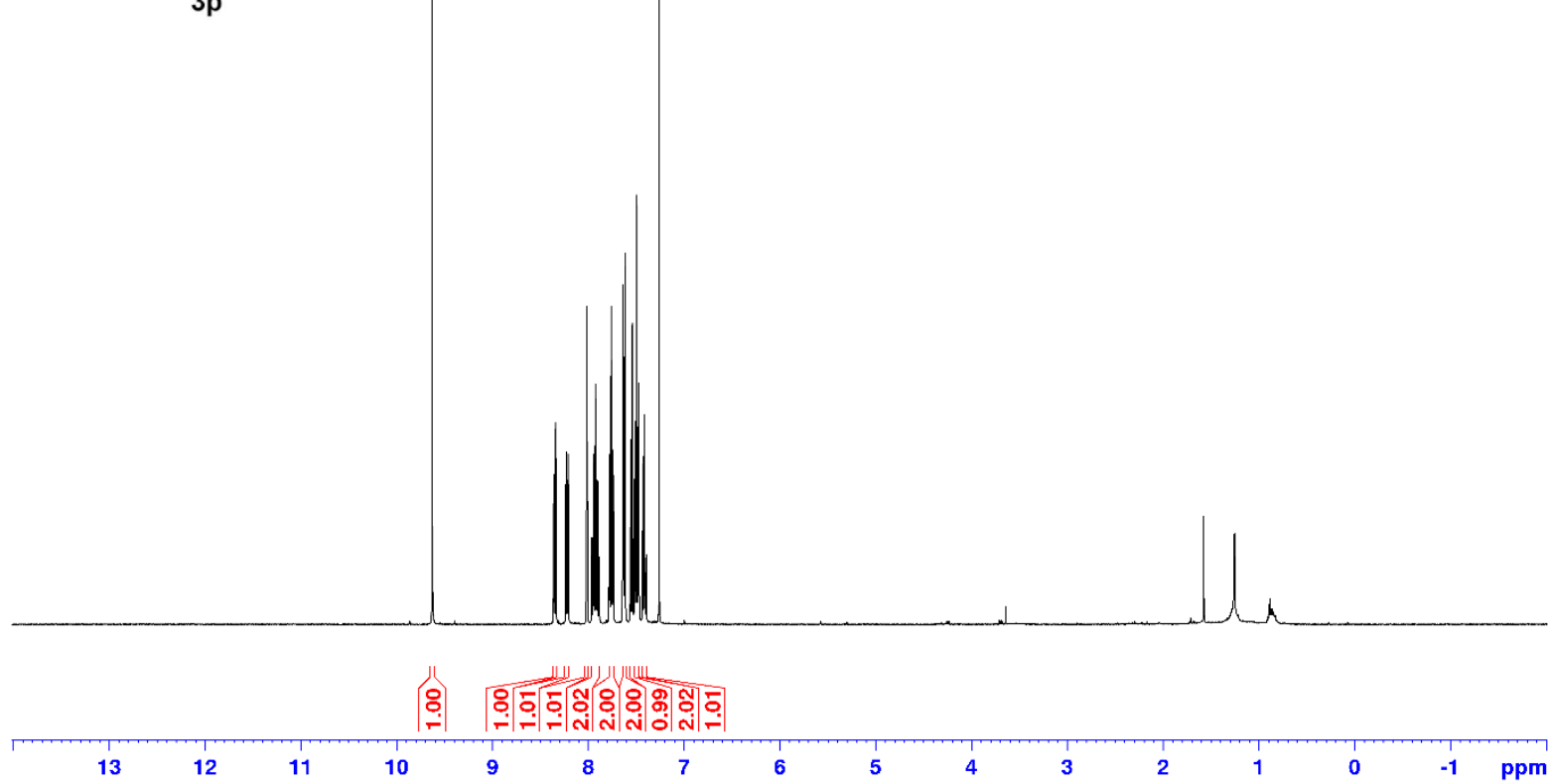

${ }^{13} \mathrm{C}$ NMR, $126 \mathrm{MHz}, \mathrm{CDCl}_{3}$

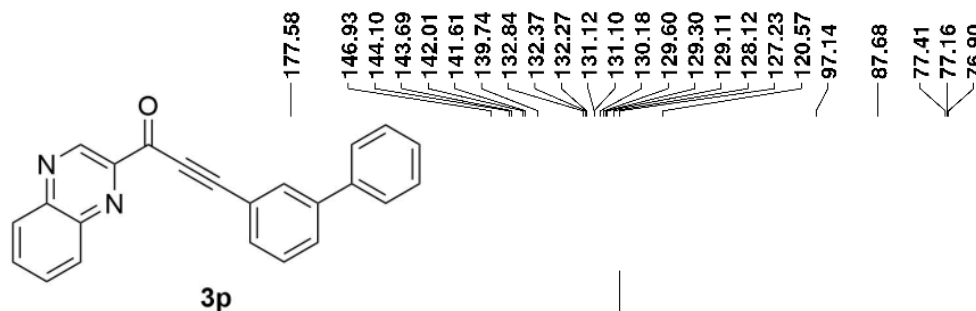

$3 p$

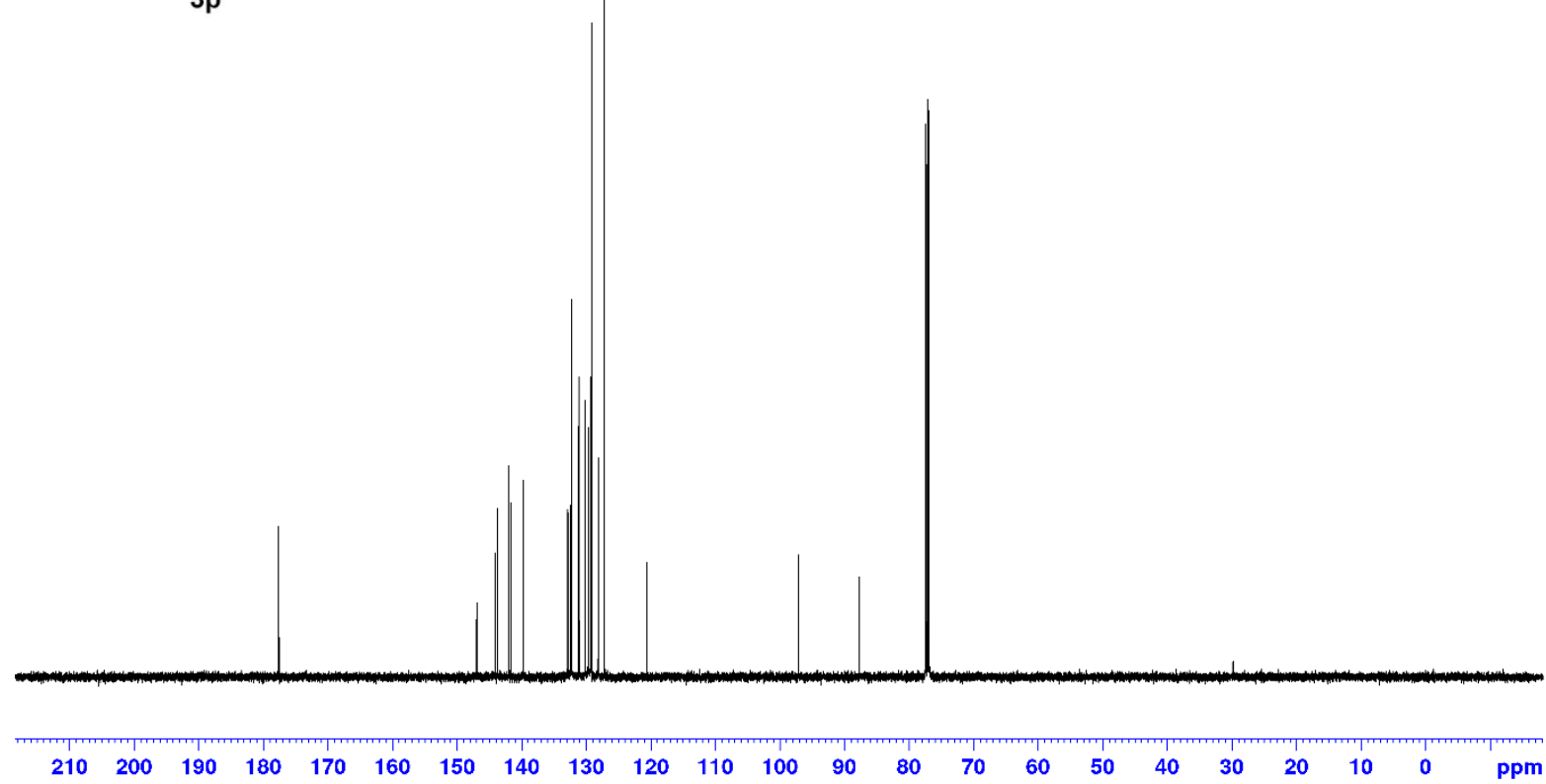


${ }^{1} \mathrm{H} \mathrm{NMR}, 400 \mathrm{MHz}, \mathrm{CDCl}_{3}$

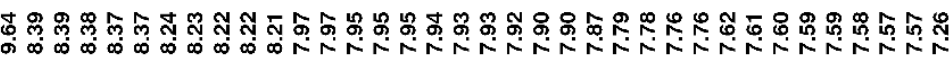<smiles>O=C(C#Cc1ccc2ccccc2c1)c1cnc2ccccc2n1</smiles>

$3 q$

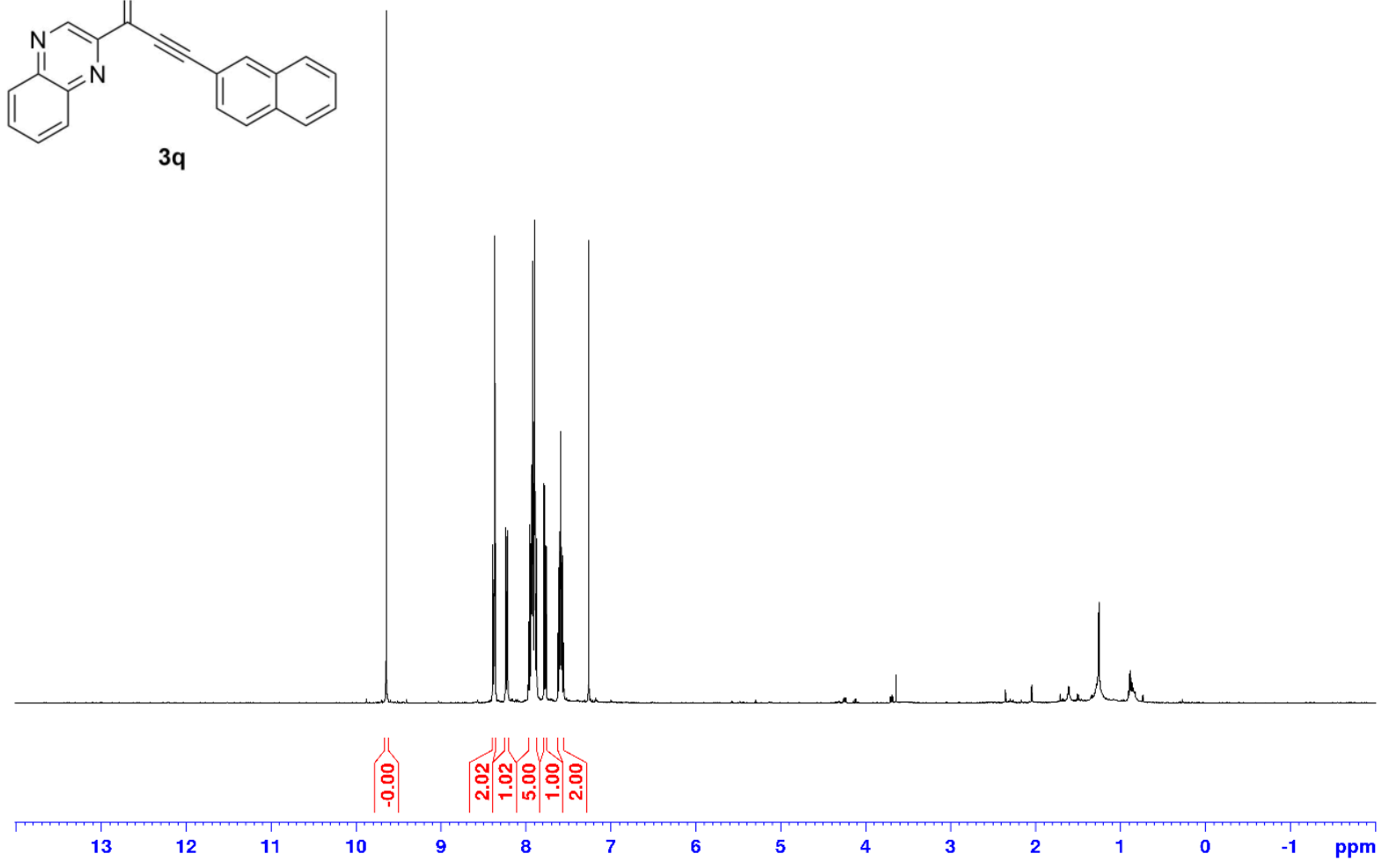

${ }^{13} \mathrm{C} \mathrm{NMR,} 126 \mathrm{MHz}, \mathrm{CDCl}_{3}$
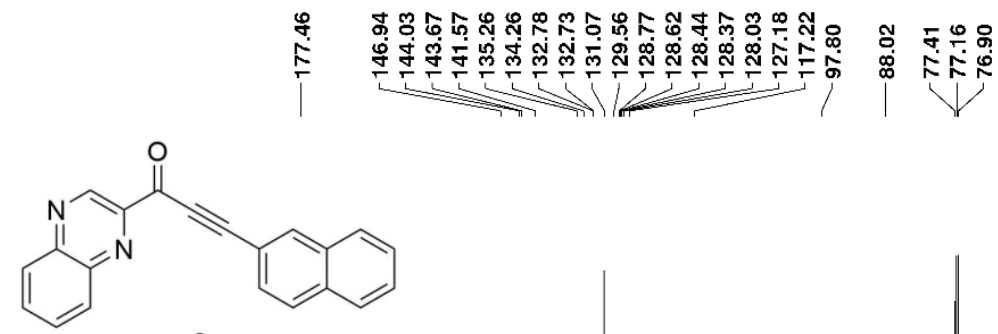

$3 q$

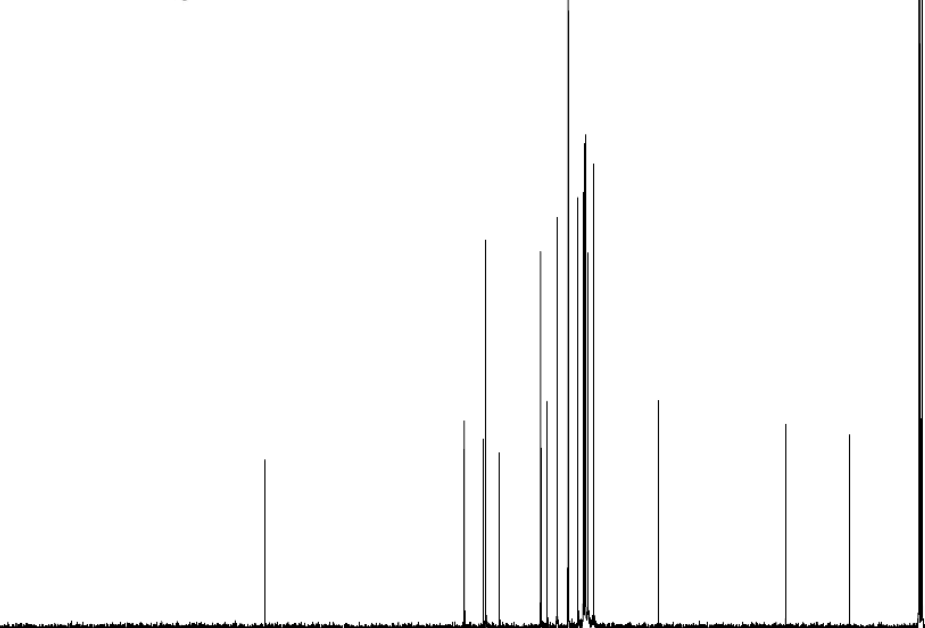

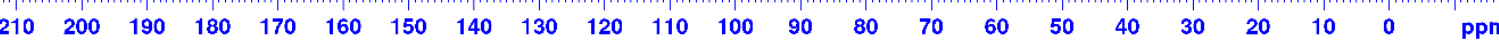


${ }^{1} \mathrm{H} \mathrm{NMR}, 400 \mathrm{MHz}, \mathrm{CDCl}_{3}$

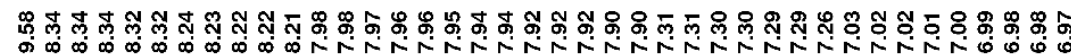<smiles>O=C(C#Cc1cc(F)cc(F)c1)c1cnc2ccccc2n1</smiles>

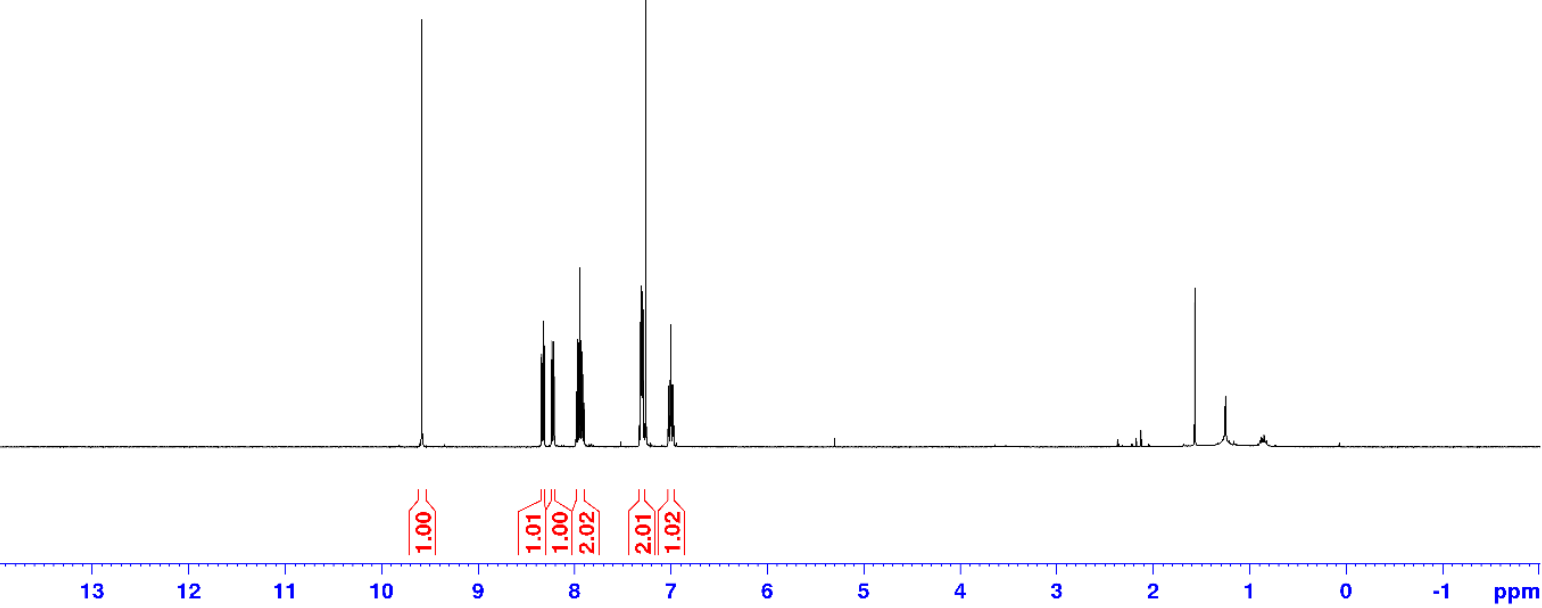

${ }^{13} \mathrm{C} \mathrm{NMR}, 126 \mathrm{MHz}, \mathrm{CDCl}_{3}$

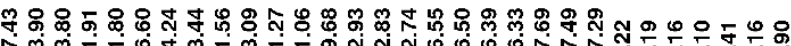<smiles>O=C(C#Cc1cc(F)cc(F)c1)c1cnc2ccccc2n1</smiles>

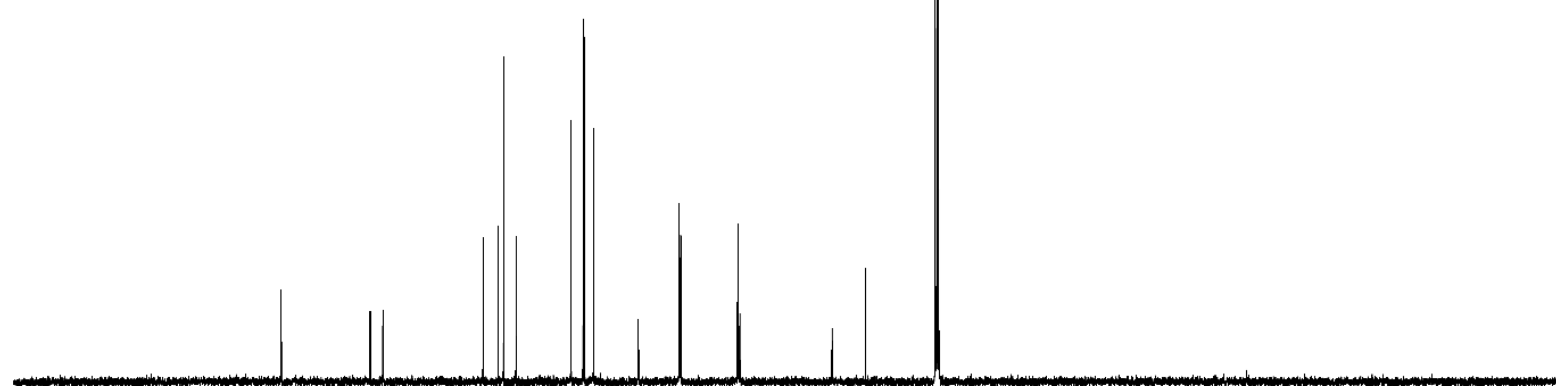

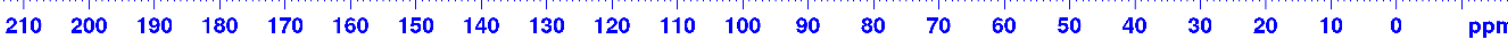


${ }^{19} \mathrm{~F} \mathrm{NMR}, 376 \mathrm{MHz}, \mathrm{CDCl}_{3}$<smiles>O=C(C#Cc1cc(F)cc(F)c1)c1cnc2ccccc2n1</smiles>

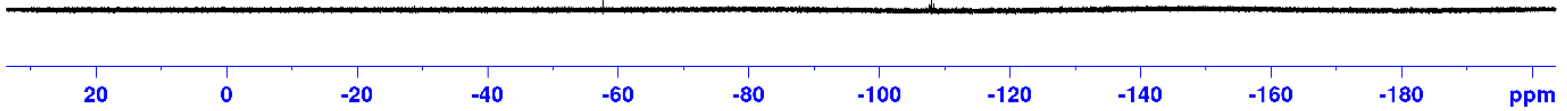

${ }^{1} \mathrm{H} \mathrm{NMR}, 400 \mathrm{MHz}, \mathrm{CDCl}_{3}$

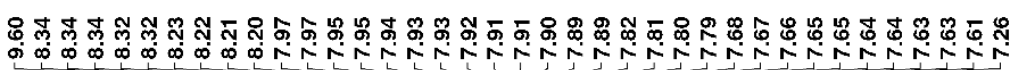<smiles>O=C(C#Cc1ccccc1C(F)(F)F)c1cnc2ccccc2n1</smiles>

3s

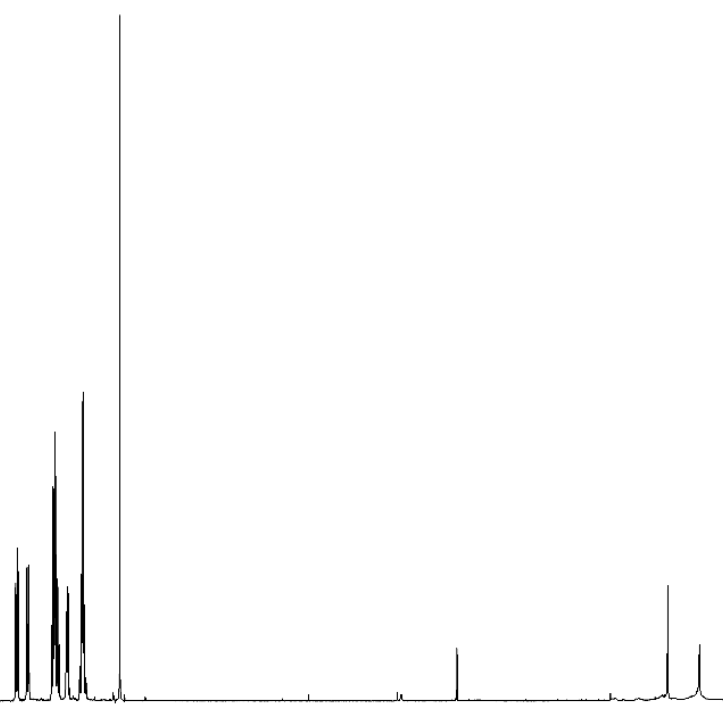

(2)

$\begin{array}{llllll}13 & 12 & 11 & 10 & 9\end{array}$

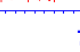

$1+1,+1$


${ }^{13} \mathrm{C} \mathrm{NMR}, 126 \mathrm{MHz}, \mathrm{CDCl}_{3}$

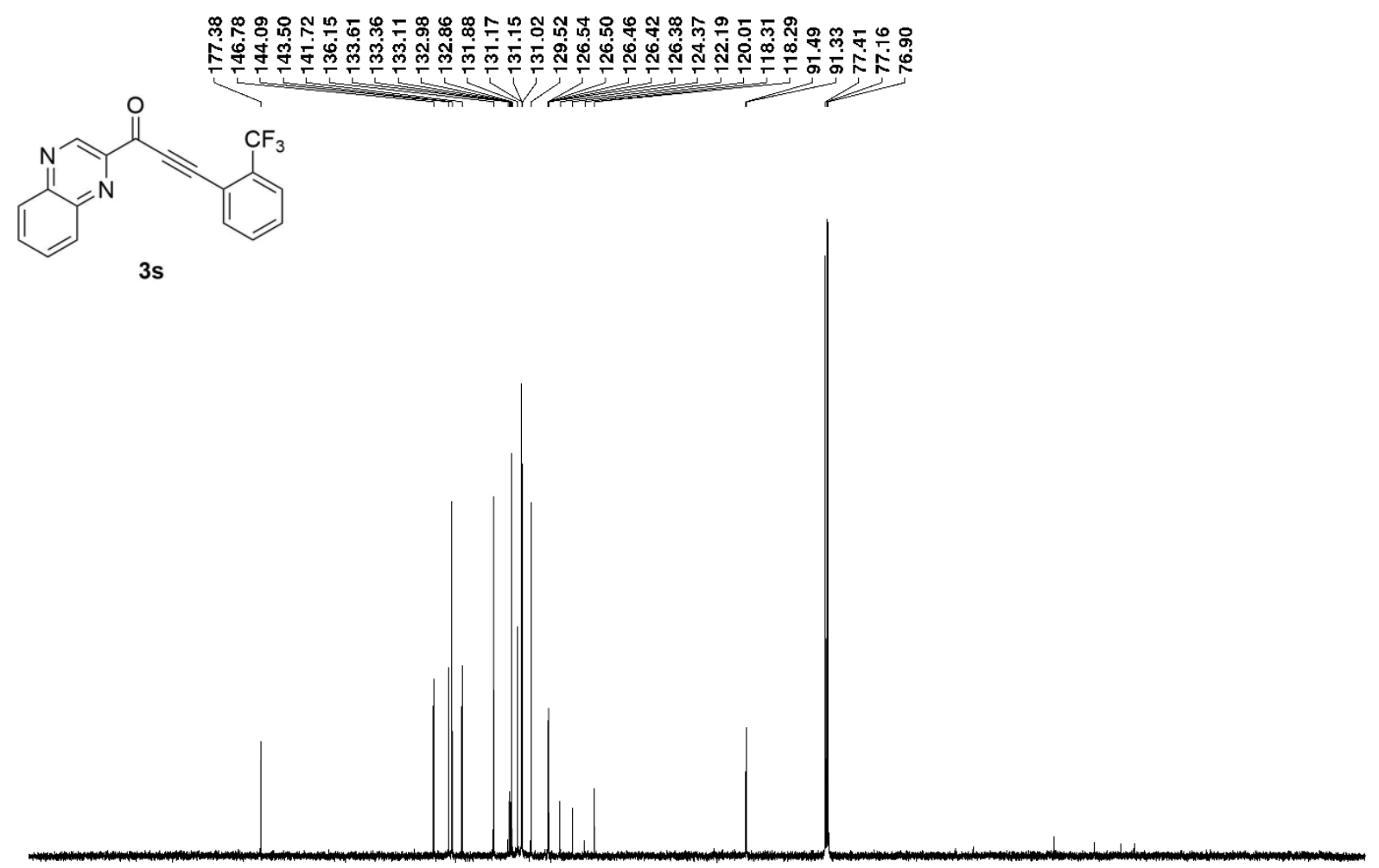

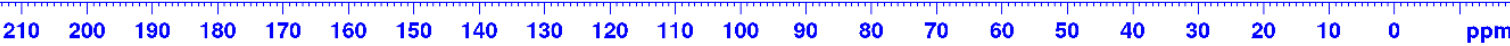

${ }^{19} \mathrm{~F}$ NMR, $376 \mathrm{MHz}, \mathrm{CDCl}_{3}$

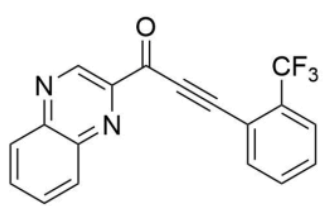

$\frac{5}{6}$

$3 s$ 
${ }^{1} \mathrm{H} \mathrm{NMR}, 400 \mathrm{MHz}, \mathrm{CDCl}_{3}$

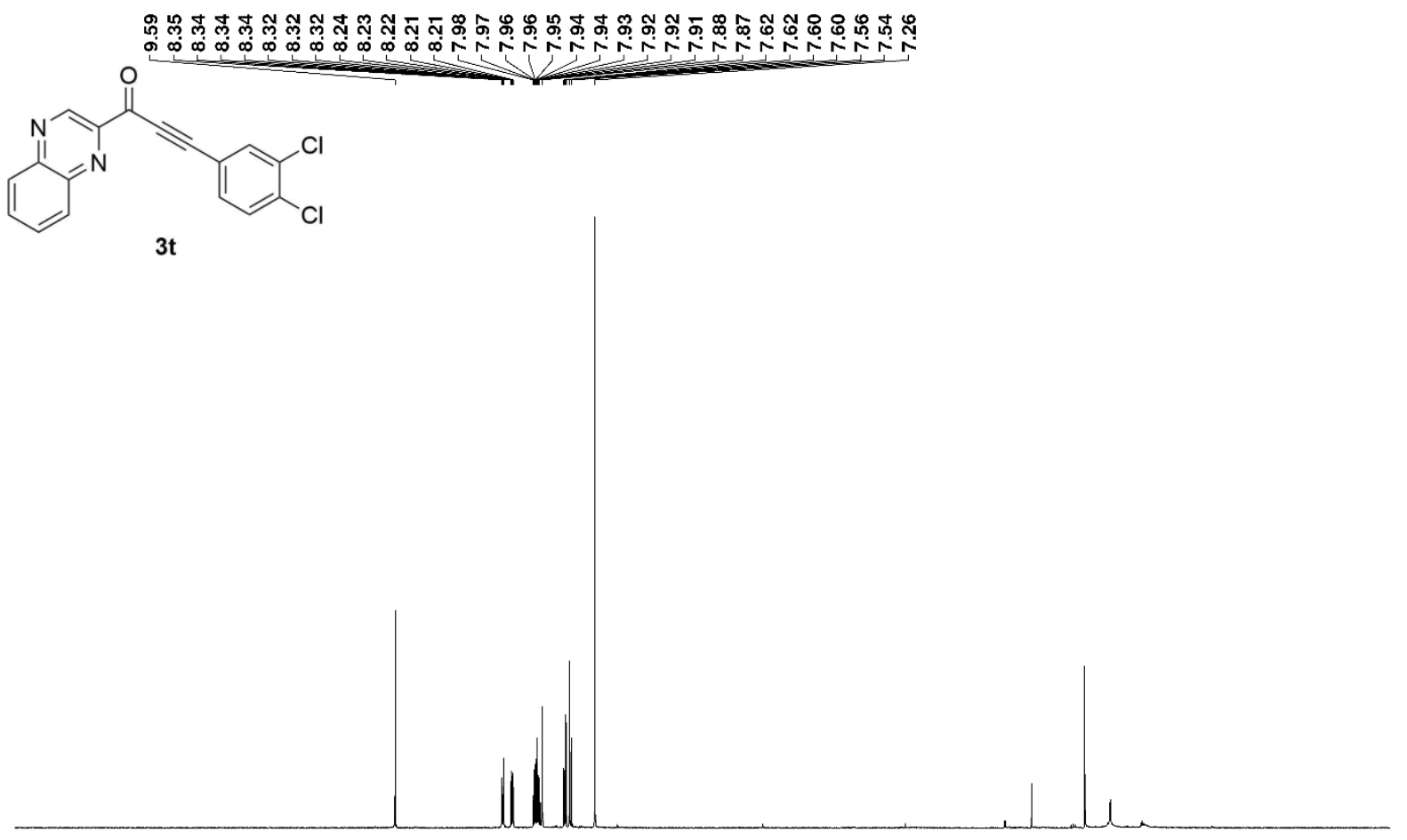

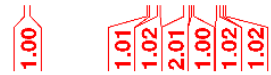

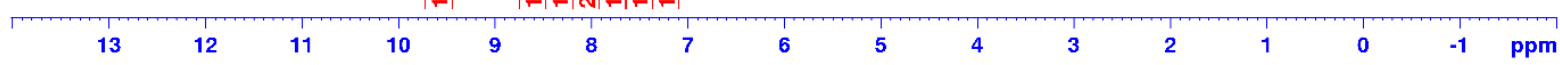

${ }^{13} \mathrm{C} \mathrm{NMR}, 126 \mathrm{MHz}, \mathrm{CDCl}_{3}$

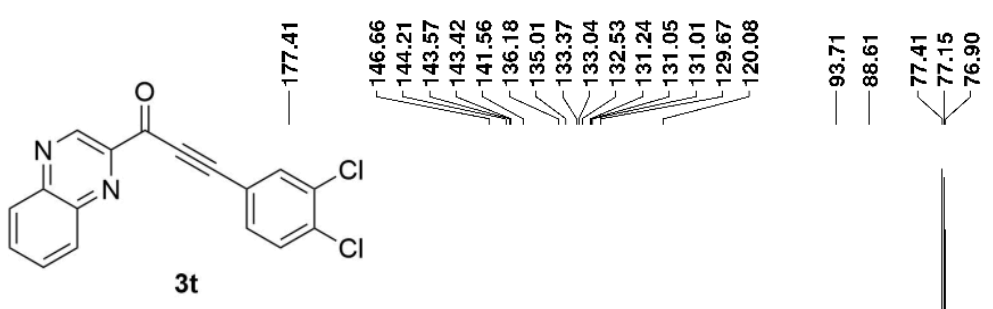

3t

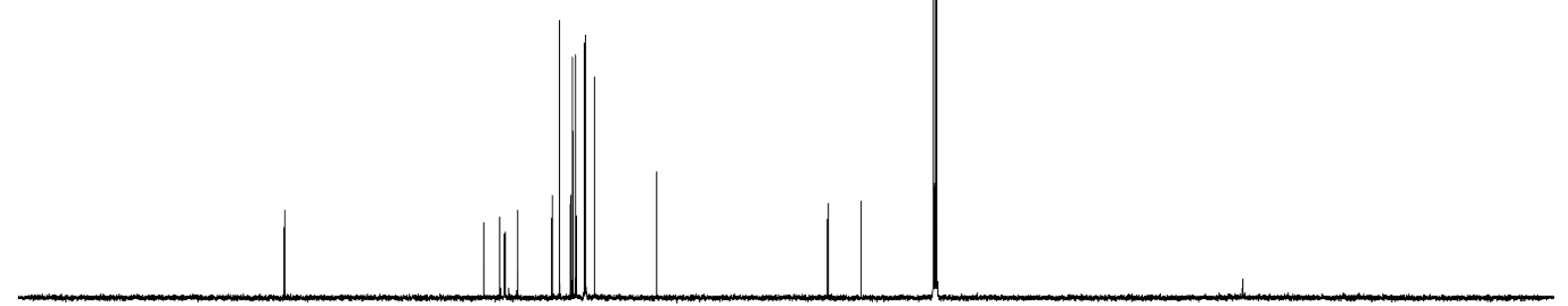

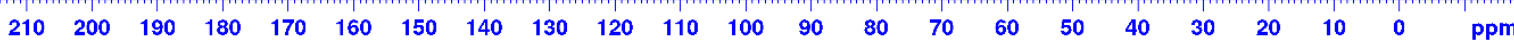


${ }^{1} \mathrm{H} \mathrm{NMR}, 400 \mathrm{MHz}, \mathrm{CDCl}_{3}$

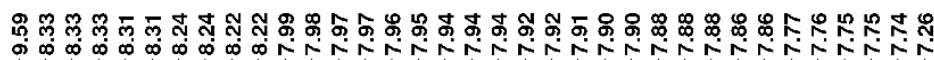<smiles>N#Cc1ccc(C#CC(=O)c2cnc3ccccc3n2)cc1</smiles>

3u

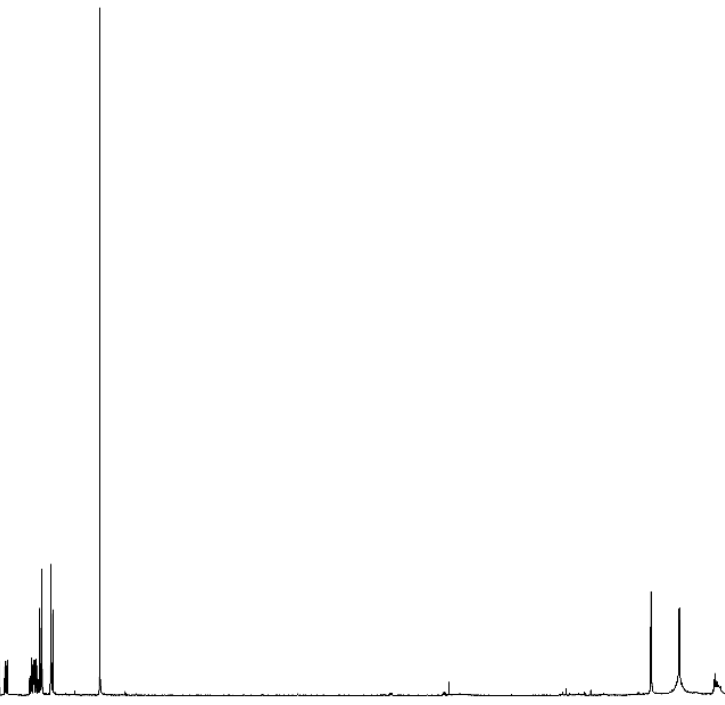

:

$13 \quad 12 \quad 11-10$

-1- ה| ता त

${ }^{13} \mathrm{C} \mathrm{NMR}, 126 \mathrm{MHz}, \mathrm{CDCl}_{3}$

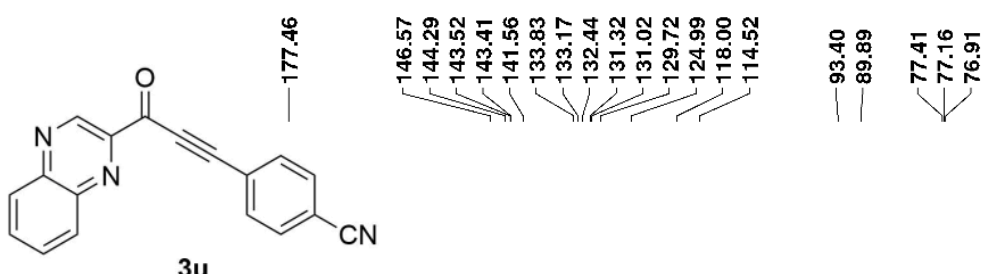

$3 u$

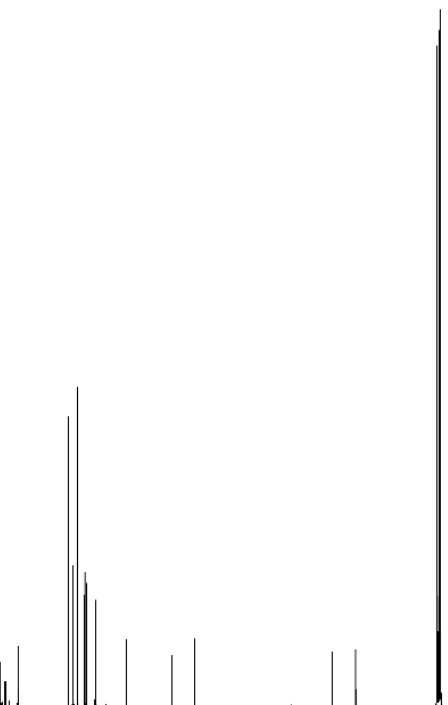

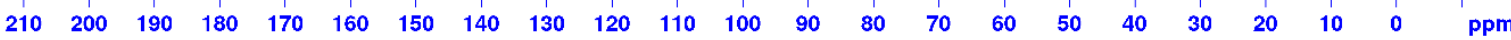


${ }^{1} \mathrm{H}$ NMR, $400 \mathrm{MHz}, \mathrm{CDCl}_{3}$
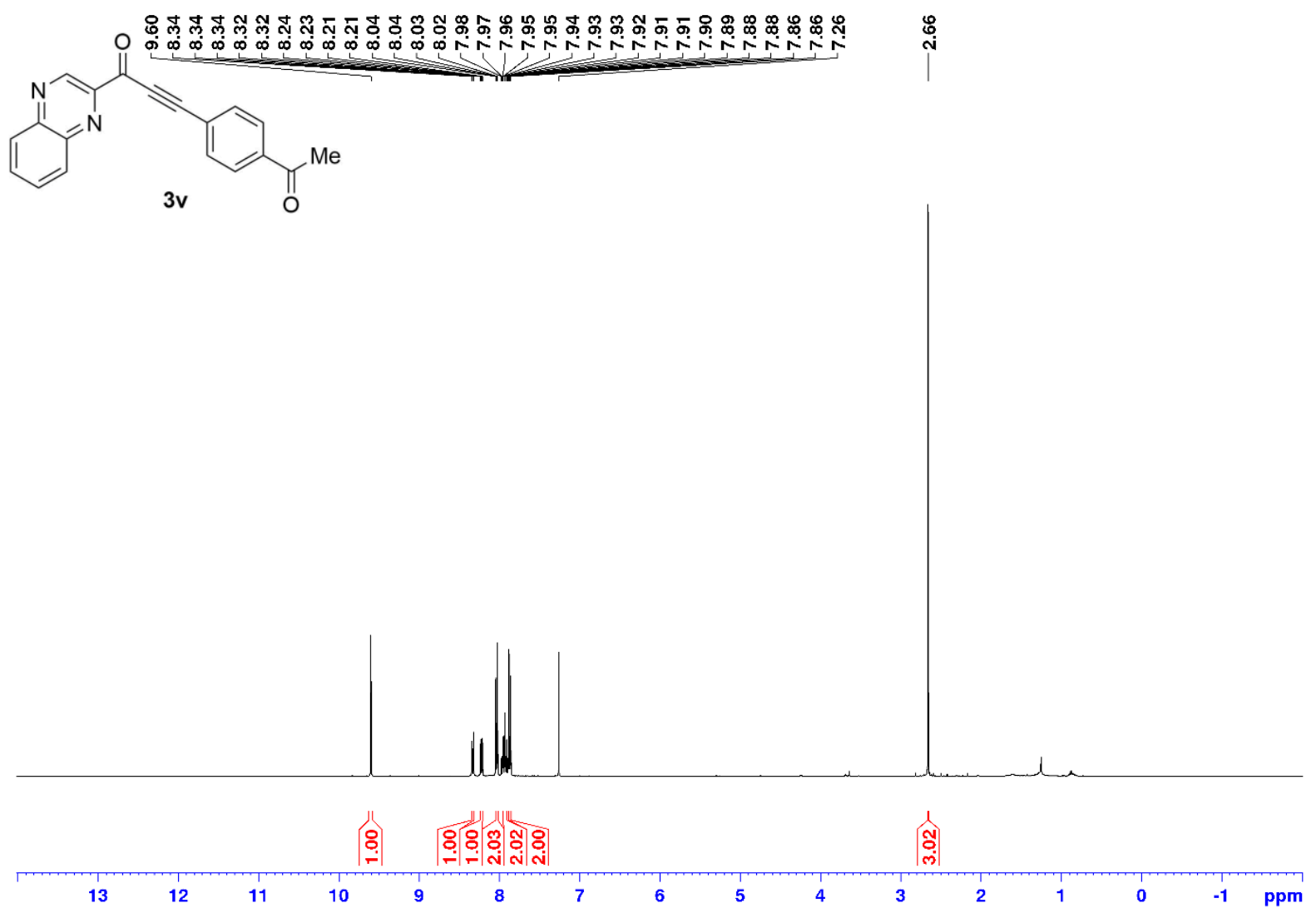

${ }^{13} \mathrm{C} \mathrm{NMR}, 126 \mathrm{MHz}, \mathrm{CDCl}_{3}$
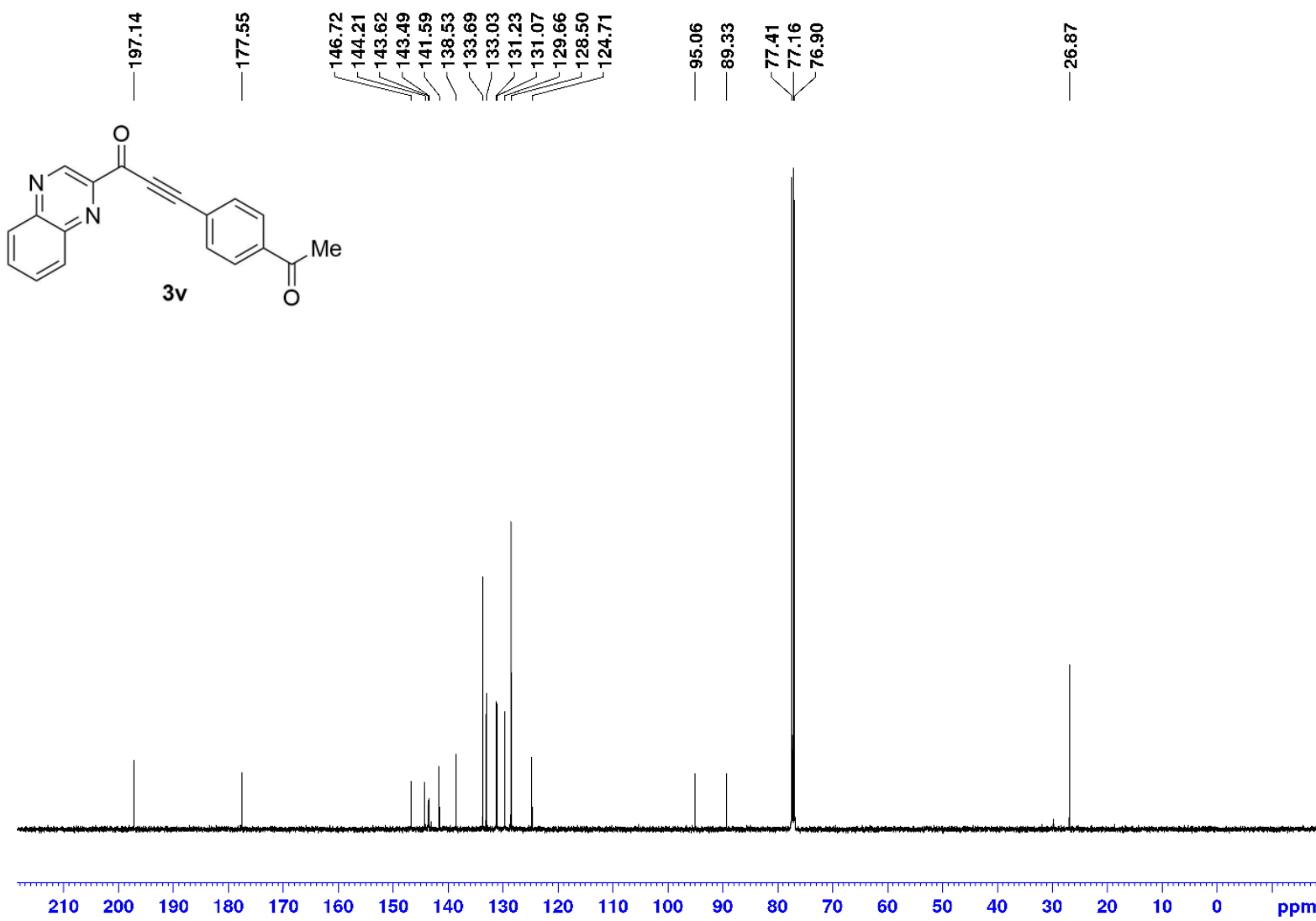
${ }^{1} \mathrm{H} \mathrm{NMR}, 400 \mathrm{MHz}, \mathrm{CDCl}_{3}$

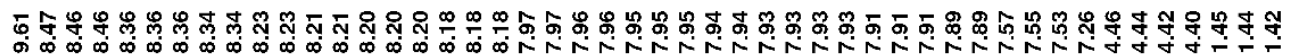

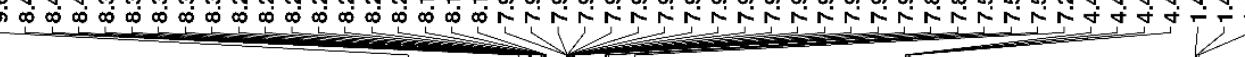<smiles>CCOC(=O)c1cccc(C#CC(=O)c2cnc3ccccc3n2)c1</smiles>

3w

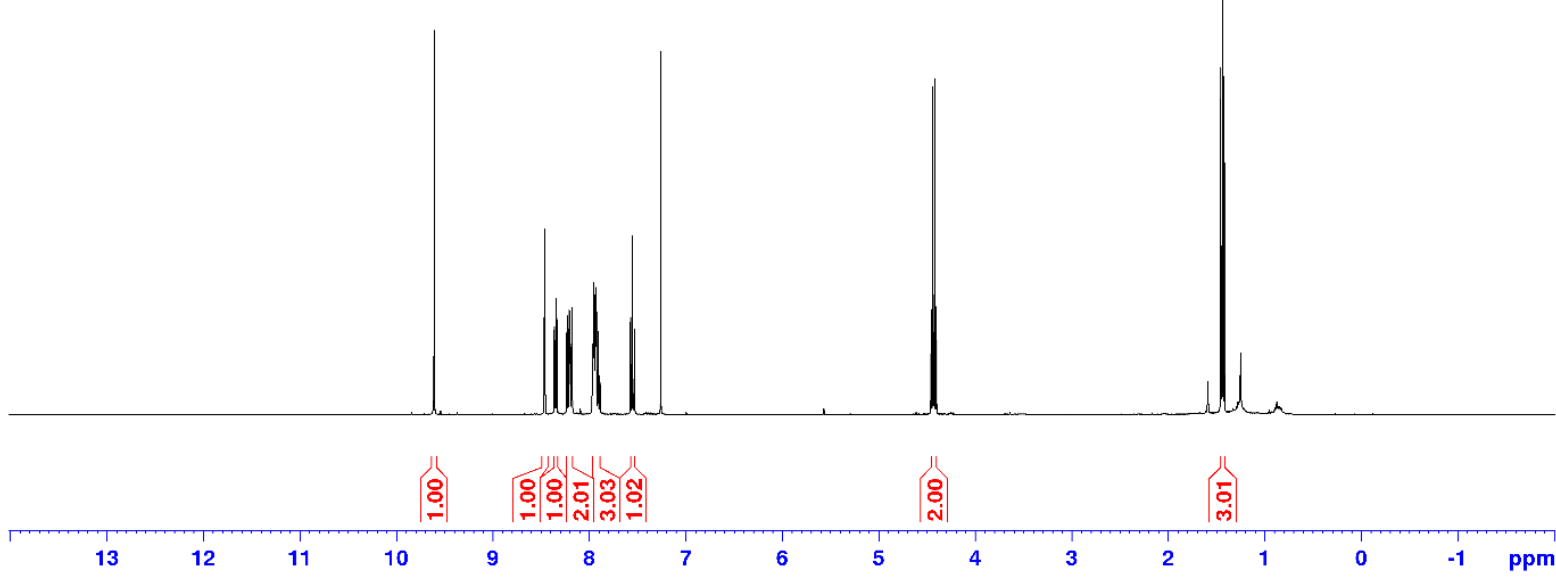

${ }^{13} \mathrm{C} \mathrm{NMR}, 126 \mathrm{MHz}, \mathrm{CDCl}_{3}$

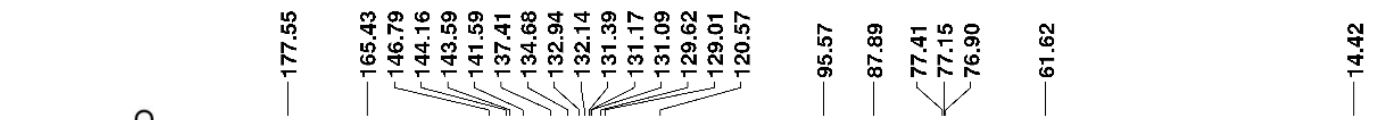<smiles>CCOC(=O)c1cccc(C#CC(=O)c2cnc3ccccc3n2)c1</smiles>

$3 w$

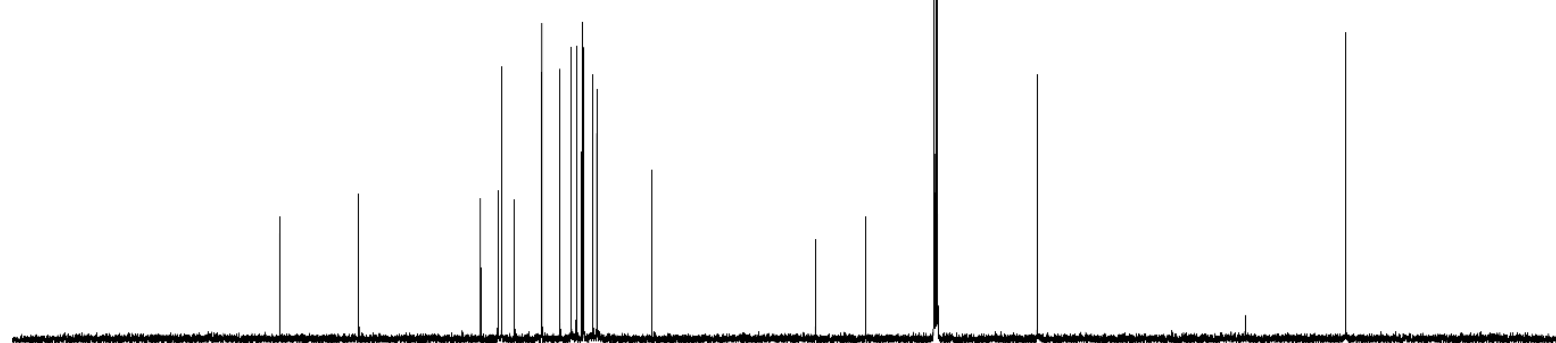

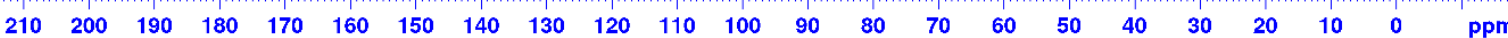


${ }^{1} \mathrm{H} \mathrm{NMR}, 400 \mathrm{MHz}, \mathrm{CDCl}_{3}$

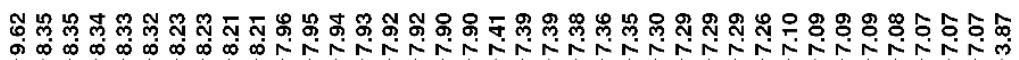<smiles>COc1cccc(C#CC(=O)c2cnc3ccccc3n2)c1</smiles>

$3 x$

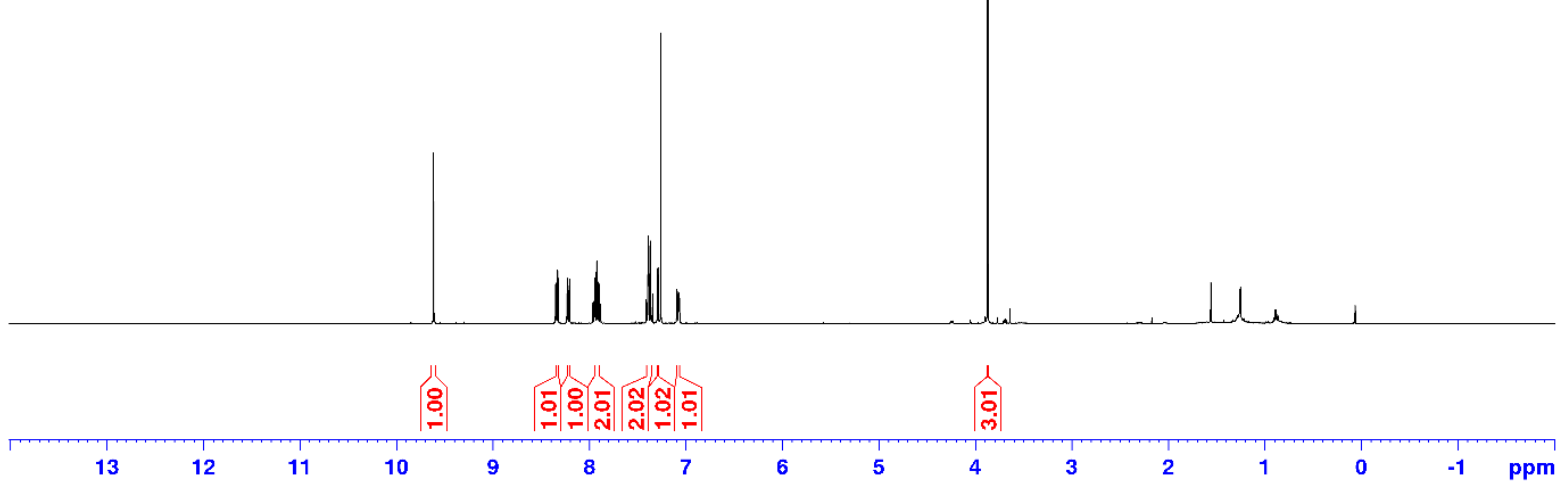

${ }^{13} \mathrm{C} \mathrm{NMR}, 126 \mathrm{MHz}, \mathrm{CDCl}_{3}$
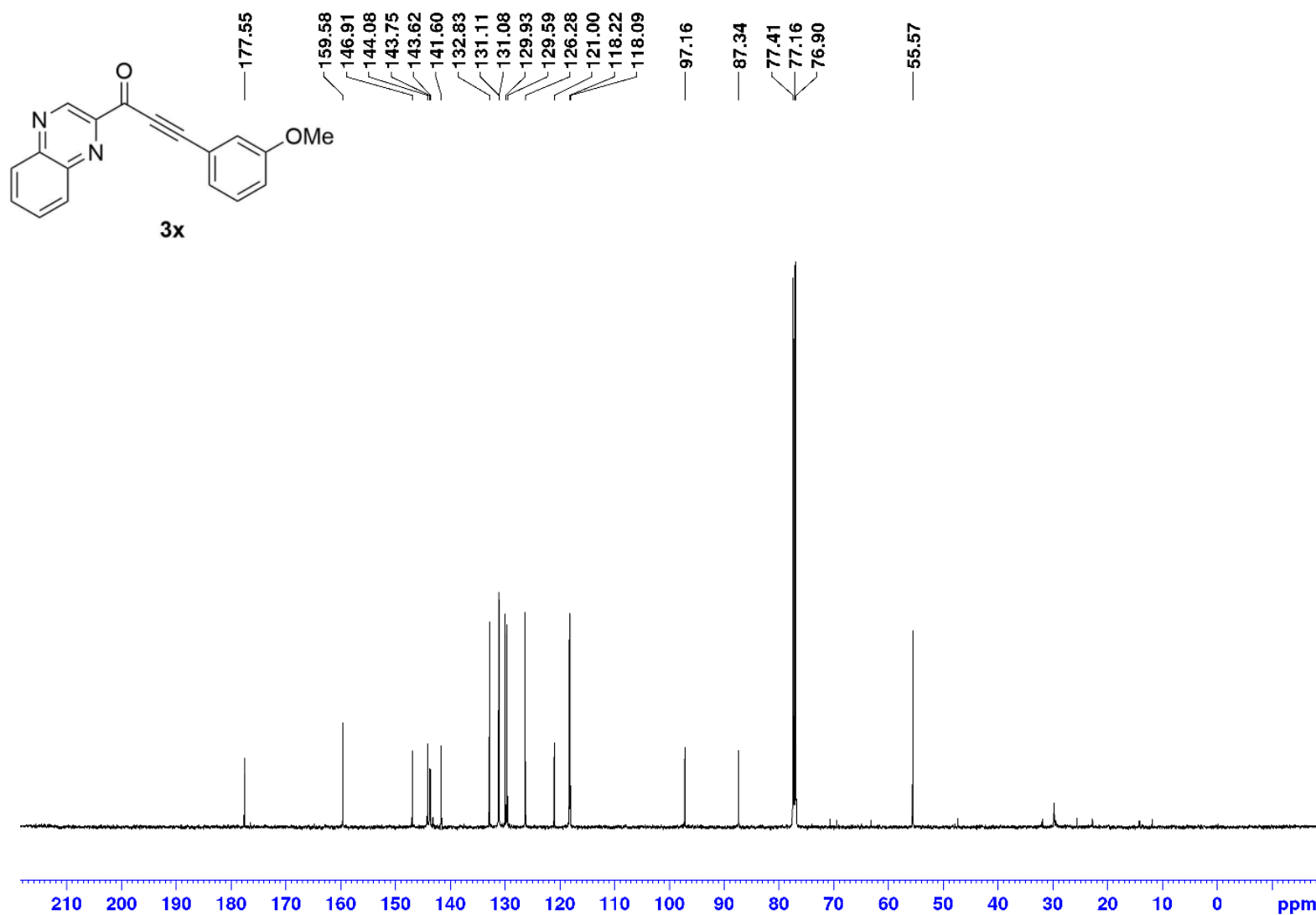
${ }^{1} \mathrm{H} \mathrm{NMR}, 400 \mathrm{MHz}, \mathrm{CDCl}_{3}$

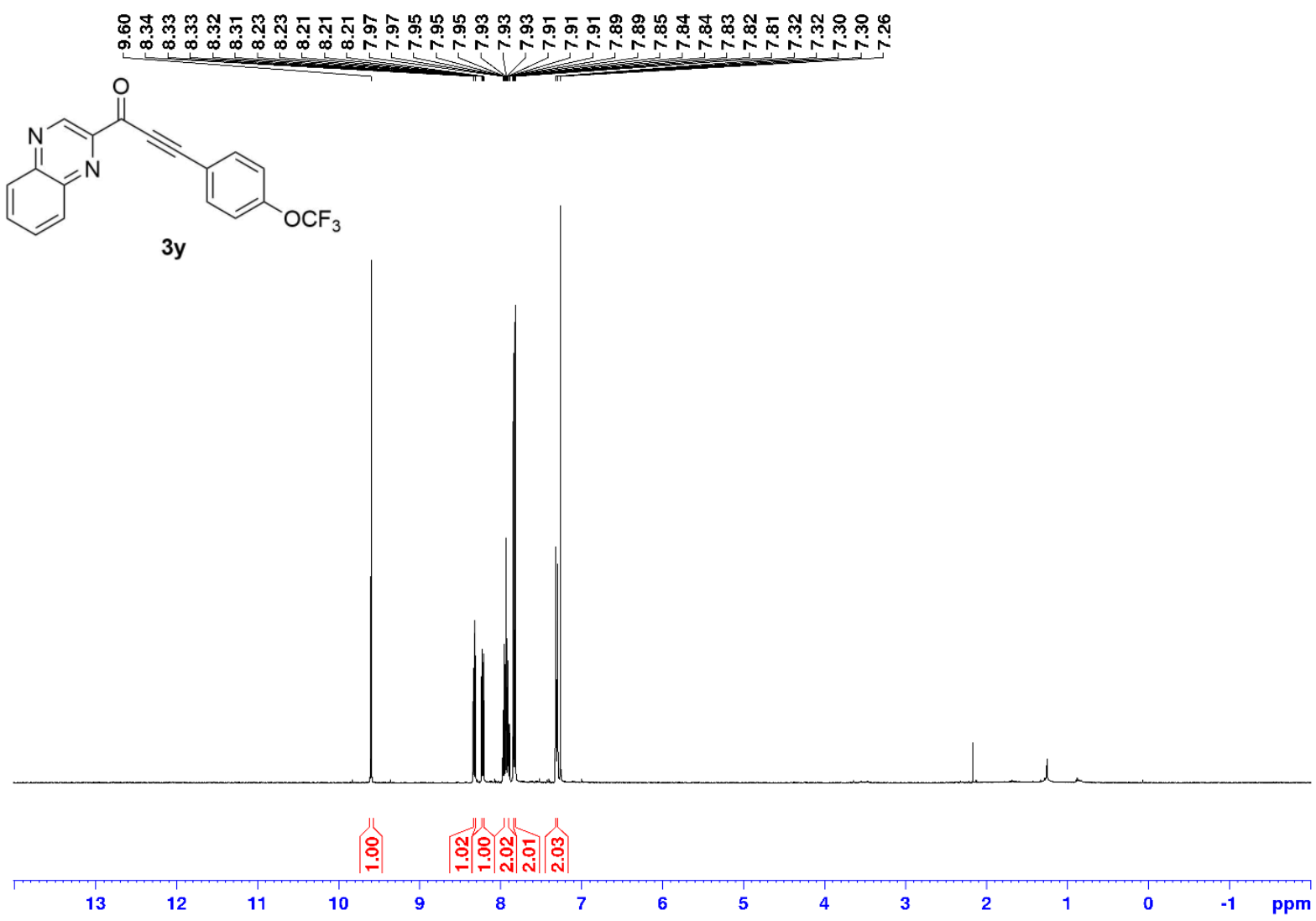

${ }^{13} \mathrm{C} \mathrm{NMR}, 126 \mathrm{MHz}, \mathrm{CDCl}_{3}$
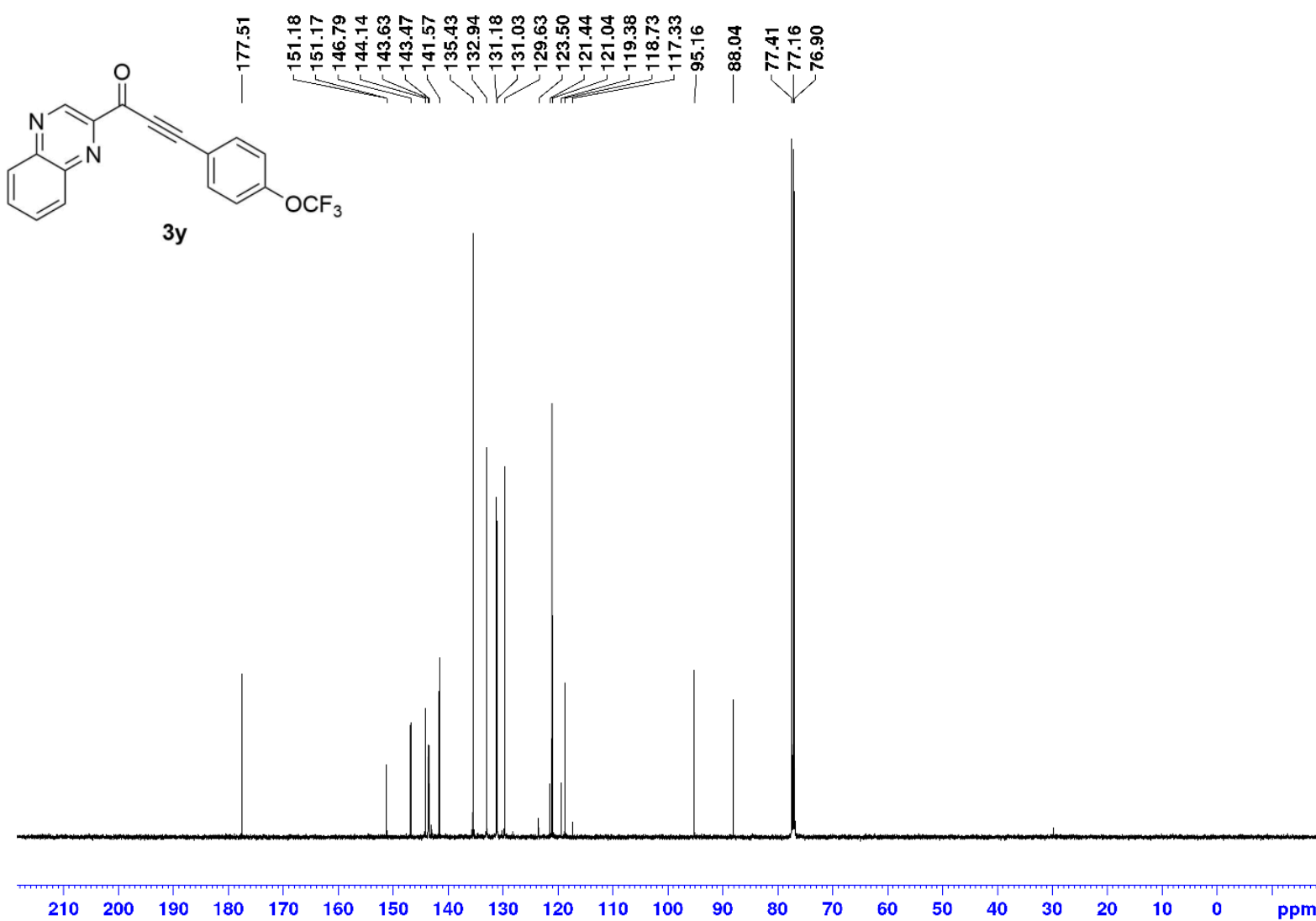
${ }^{19} \mathrm{~F} \mathrm{NMR}, 376 \mathrm{MHz}, \mathrm{CDCl}_{3}$<smiles>O=C(C#Cc1ccc(OC(F)(F)F)cc1)c1cnc2ccccc2n1</smiles>

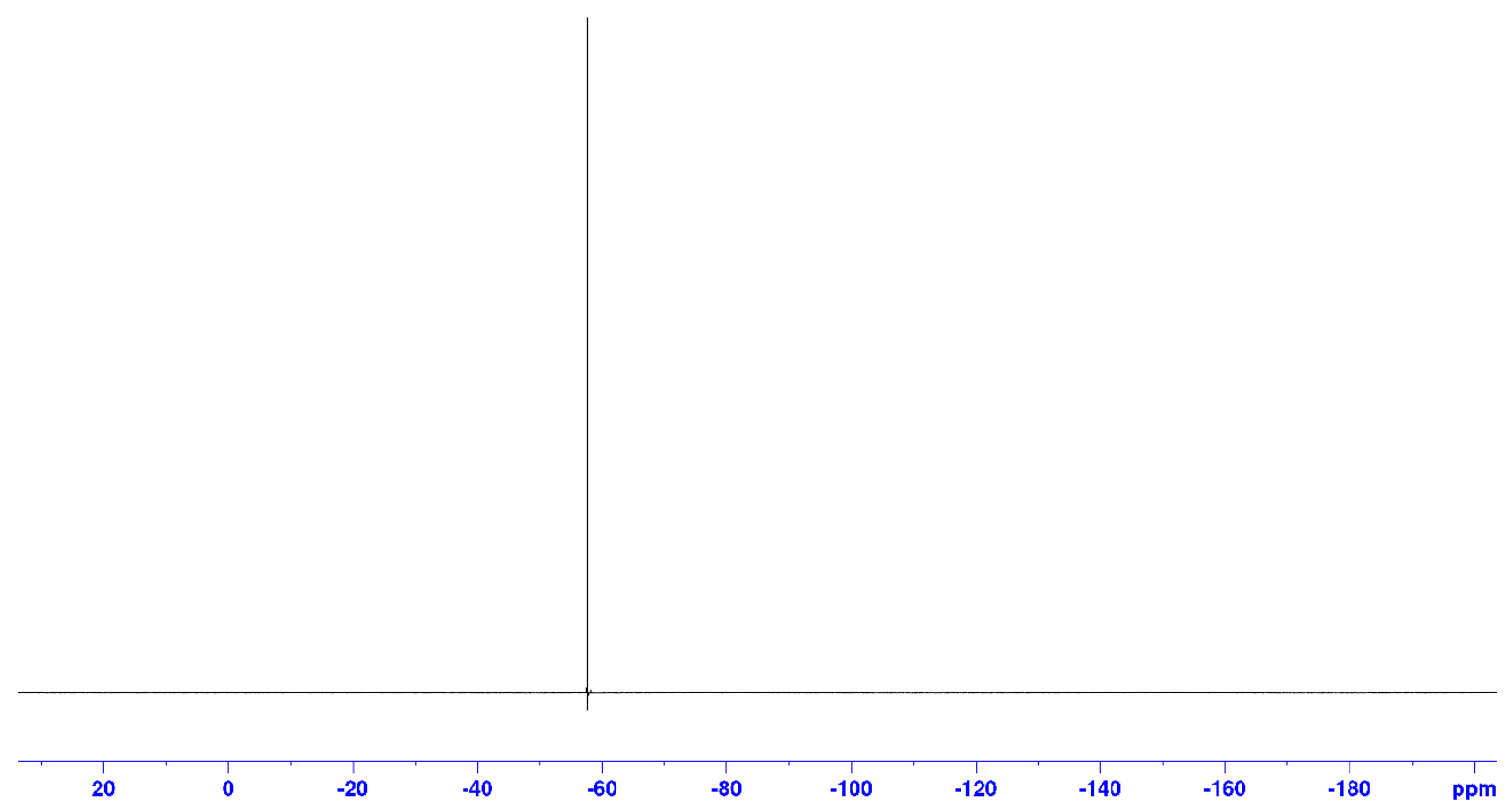

${ }^{1} \mathrm{H} \mathrm{NMR}, 400 \mathrm{MHz}, \mathrm{CDCl}_{3}$

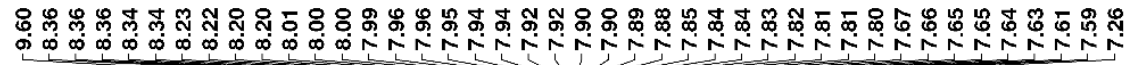<smiles>O=C(C#Cc1cccc(N2C(=O)c3ccccc3C2=O)c1)c1cnc2ccccc2n1</smiles>

$3 z$

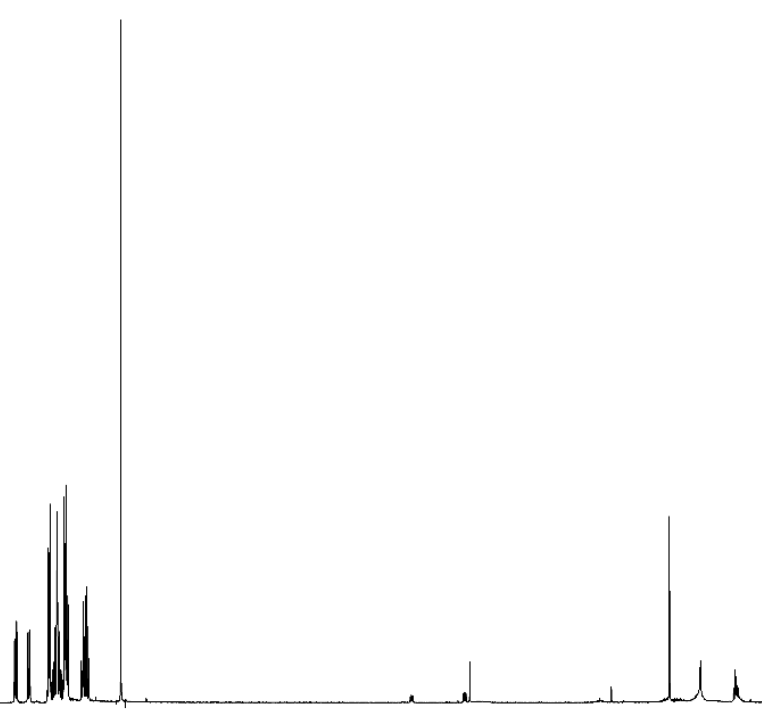

(o)

$\begin{array}{lllllll}13 & 12 & 11 & 10 & 9 & 8 & 7\end{array}$ 
${ }^{13} \mathrm{C} \mathrm{NMR}, 126 \mathrm{MHz}, \mathrm{CDCl}_{3}$
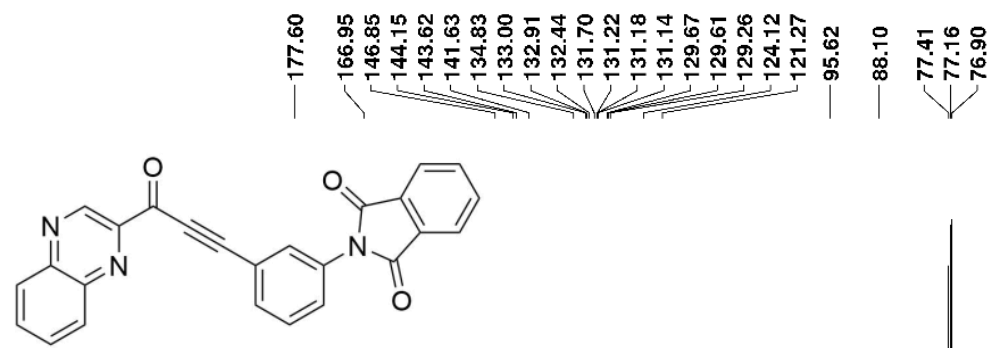

$3 z$
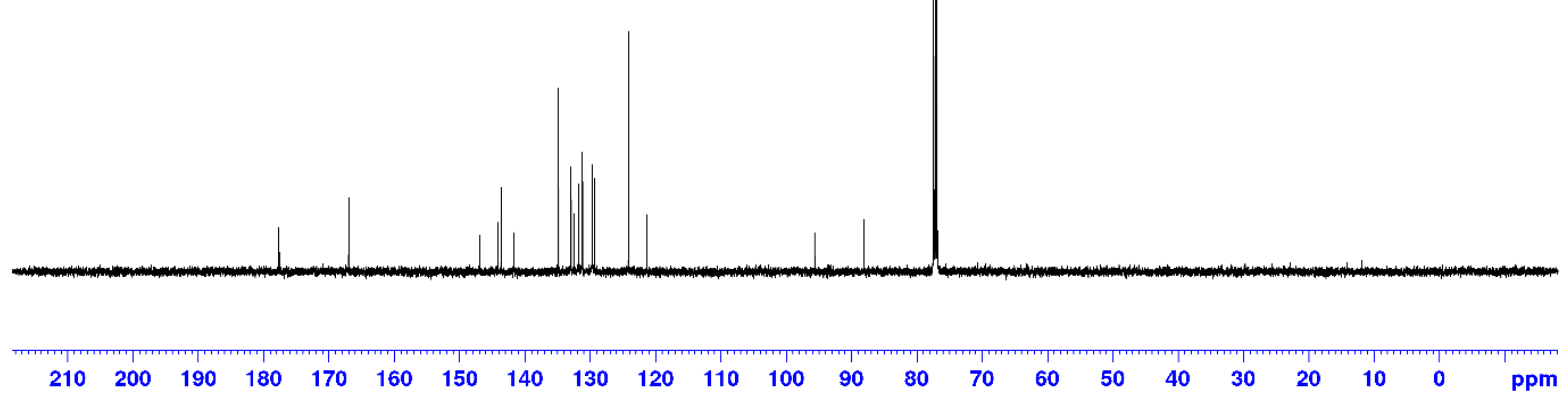

${ }^{1} \mathrm{H}$ NMR, $400 \mathrm{MHz}, \mathrm{CDCl}_{3}$

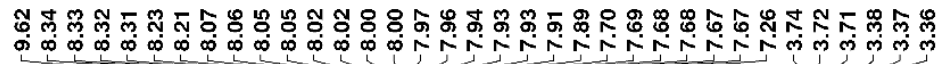

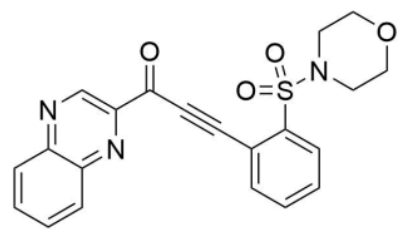

3aa

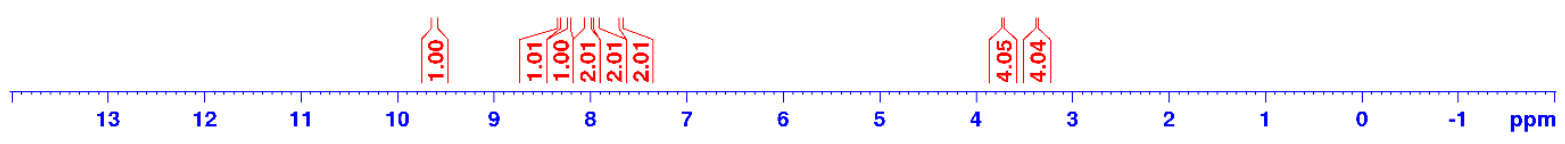

S-76 
${ }^{13} \mathrm{C}$ NMR, $126 \mathrm{MHz}, \mathrm{CDCl}_{3}$

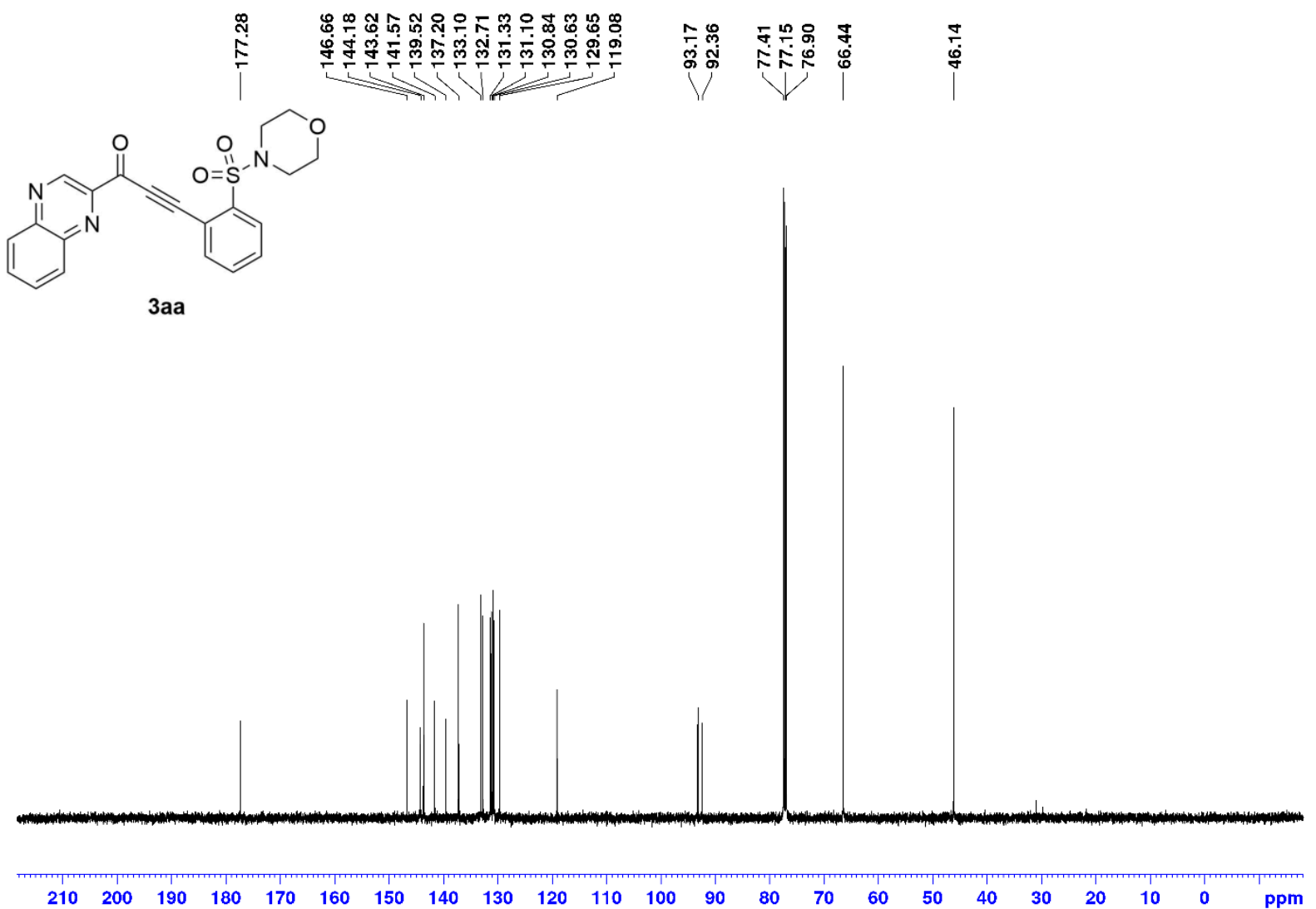

${ }^{13} \mathrm{C}$ NMR (without NOE), $126 \mathrm{MHz}, \mathrm{CDCl}_{3}$

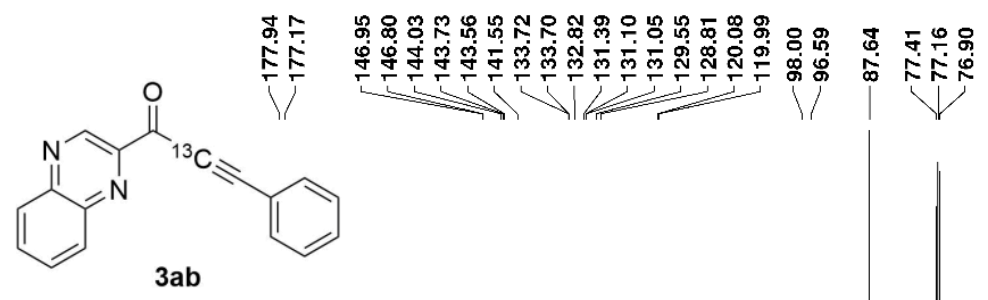

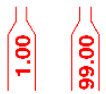

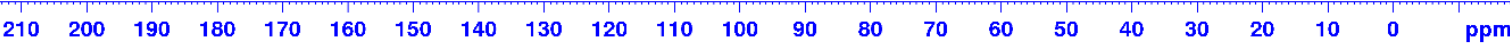




\section{Structures and Cartesian Coordinates of Stationary Points}

1g (toluene)

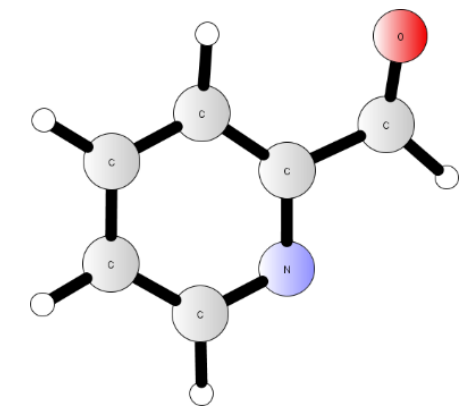

$\begin{array}{lrrr}\text { C } & -0.501807000 & -0.195308000 & -0.000052000 \\ \text { C } & -0.009512000 & 1.114955000 & 0.000007000 \\ \text { C } & 1.371369000 & 1.300771000 & 0.000208000 \\ \text { C } & 2.197992000 & 0.175722000 & 0.000330000 \\ \text { C } & 1.609365000 & -1.094207000 & 0.000236000 \\ \text { N } & 0.286844000 & -1.285356000 & 0.000048000 \\ \text { H } & 1.795511000 & 2.300177000 & 0.000268000 \\ \text { H } & -0.704064000 & 1.948023000 & -0.000100000 \\ \text { H } & 3.278858000 & 0.272806000 & 0.000490000 \\ \text { H } & 2.226813000 & -1.989145000 & 0.000331000 \\ \text { C } & -1.962968000 & -0.476539000 & -0.000277000 \\ \text { O } & -2.827360000 & 0.383531000 & -0.000475000 \\ \text { H } & -2.212789000 & -1.554981000 & -0.000236000\end{array}$

2a (toluene)

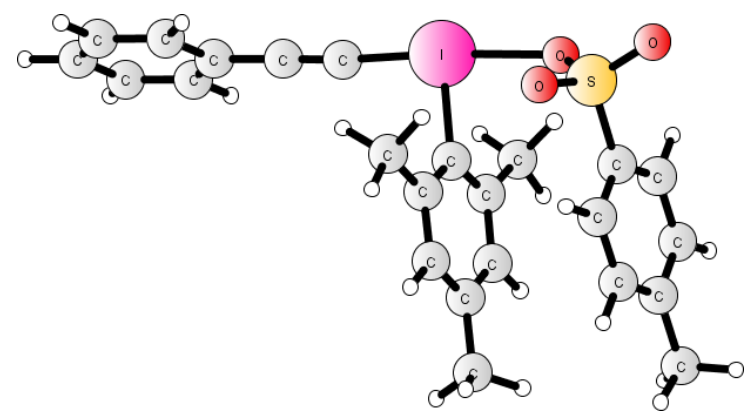

$\begin{array}{ccc}-5.62773700 & -0.61246400 & -1.80558700 \\ -7.84354700 & 1.25503900 & -0.01270100 \\ -7.44063400 & 2.14299800 & 1.91290100 \\ -7.95093800 & 0.25546000 & -1.92286200 \\ -8.85934800 & 1.63524000 & -0.06464200 \\ 1.37243100 & -2.24690500 & 0.68908100 \\ 2.41067200 & -2.24833400 & -0.45298600 \\ 3.32238800 & -3.40102000 & -0.31548300 \\ 1.74214900 & -2.07038300 & -1.76559800 \\ 3.37587400 & -0.76162600 & -0.15656900 \\ 3.58371500 & 0.14705400 & -1.18964000 \\ 3.93993300 & -0.54738900 & 1.10510400 \\ 4.35734000 & 1.28664700 & -0.95431000 \\ 3.13309900 & -0.03213000 & -2.15867100 \\ 4.70253100 & 0.59530200 & 1.32695300 \\ 3.77866800 & -1.26512700 & 1.90247600 \\ 4.92429500 & 1.53072300 & 0.30104600 \\ 4.51208000 & 1.99992300 & -1.75930200 \\ 5.13668100 & 0.76571100 & 2.30917400 \\ 5.75050600 & 2.76595600 & 0.55935900 \\ 6.77822500 & 2.50291200 & 0.83684800 \\ 5.79697700 & 3.40777600 & -0.32497300 \\ 5.33660400 & 3.35568000 & 1.38610500 \\ -0.60646200 & 0.22288900 & -2.44504800 \\ -0.15268200 & -0.76326000 & -2.58803200 \\ -1.68178000 & 0.09038400 & -2.28267900 \\ -0.47408700 & 0.79831600 & -3.36409800 \\ 0.77306300 & 0.47226000 & 2.48509300 \\ -0.23027500 & 0.36096000 & 2.91195400 \\ 1.24582800 & -0.51423900 & 2.47659300 \\ 1.35011900 & 1.12484200 & 3.14379200 \\ 2.04335300 & 4.14765700 & -0.71271800 \\ 2.98407300 & 4.20979500 & -0.15722500 \\ 2.26173600 & 4.28410300 & -1.77567000 \\ 1.41750800 & 4.98996300 & -0.39202400\end{array}$

$3 g$ (toluene)

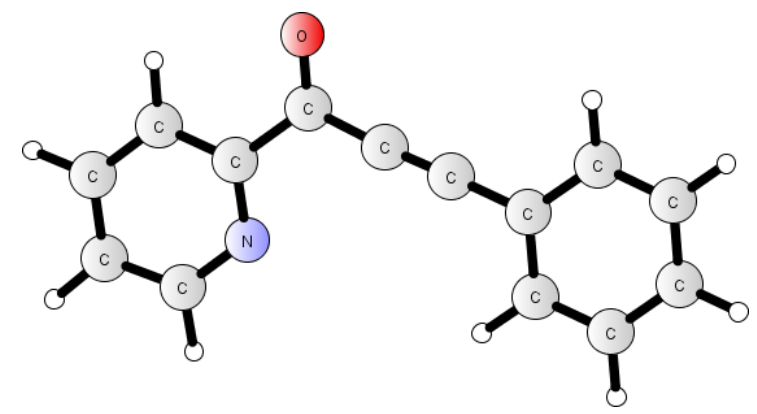

C $\quad-2.48469000 \quad 0.34103900 \quad-0.00004800$

$\begin{array}{lllll}\text { C } & -3.82304100 & 0.75007900 & 0.00001000\end{array}$

C $\quad-4.81416300-0.22957300 \quad-0.00005300$

C $\quad-4.43059900-1.57132200-0.00011900$

C $\quad-3.06533200-1.87793000 \quad-0.00014100$

N $\quad-2.10645400-0.94758700 \quad-0.00010600$

H $\quad-5.86387100 \quad 0.04761700 \quad-0.00002300$

H $\quad-4.05841100 \quad 1.80807600 \quad 0.00012200$

H $\quad-5.16765200-2.36799100 \quad-0.00014000$

$\mathrm{H} \quad-2.73201900-2.91303600-0.00014200$ 


$\begin{array}{lrrr}\text { C } & -1.39604600 & 1.37553400 & 0.00012700 \\ \text { O } & -1.65665100 & 2.57914200 & 0.00039400 \\ \text { C } & -0.03907000 & 0.89977200 & 0.00003300 \\ \text { C } & 1.13215200 & 0.56762400 & -0.00014600 \\ \text { C } & 2.48964100 & 0.14541600 & -0.00005800 \\ \text { C } & 3.53322400 & 1.09390200 & -0.00034900 \\ \text { C } & 2.80019600 & -1.23054700 & 0.00025900 \\ \text { C } & 4.85982500 & 0.66920700 & -0.00027400 \\ \text { H } & 3.28934300 & 2.15119600 & -0.00062000 \\ \text { C } & 4.13014100 & -1.64372800 & 0.00031300 \\ \text { H } & 1.99223500 & -1.95475200 & 0.00048900 \\ \text { C } & 5.16070700 & -0.69719400 & 0.00007100 \\ \text { H } & 5.66009900 & 1.40298300 & -0.00047400 \\ \text { H } & 4.36466100 & -2.70386700 & 0.00054700 \\ \text { H } & 6.19633800 & -1.02392900 & 0.00007700\end{array}$

A (toluene)

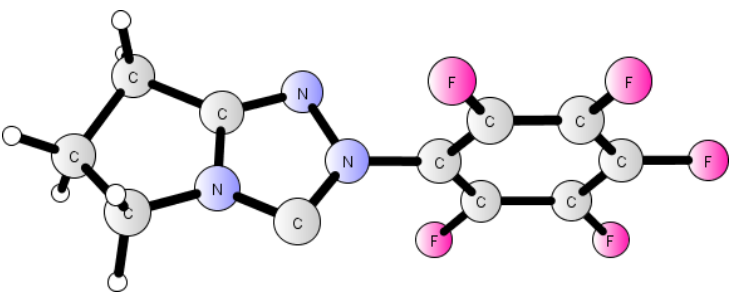

B (toluene)

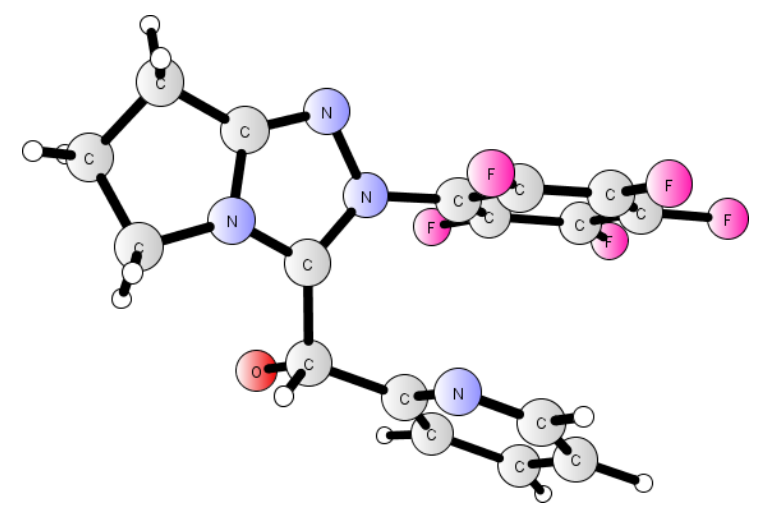

C

$\mathrm{H}$

C

C

C

C

$\mathrm{H}$

C

\begin{abstract}
$\begin{array}{lll}1.45506200 & 1.86026300 & 0.50076500\end{array}$ $\begin{array}{lll}1.88320500 & 2.09682000 & 1.50864800\end{array}$ $\begin{array}{lll}-0.06037100 & 2.02610800 & 0.68233400\end{array}$ $\begin{array}{llll}-0.77661700 & 2.82003800 & -0.21436800\end{array}$ $\begin{array}{lll}-1.94958600 & 1.55183600 & 1.90369800\end{array}$ $\begin{array}{llll}-2.15056400 & 2.96700900 & -0.02338500\end{array}$ $\begin{array}{llll}-0.23390000 & 3.28341300 & -1.03039200\end{array}$ $\begin{array}{lll}-2.75405500 & 2.31883900 & 1.05686400\end{array}$ $\begin{array}{lll}-2.38262300 & 1.03182600 & 2.75600800\end{array}$ $\begin{array}{llll}-2.74226100 & 3.57146100 & -0.70519900\end{array}$ $\begin{array}{lll}-3.81994600 & 2.40300600 & 1.24443400\end{array}$ $\begin{array}{lll}2.00847000 & 2.50022100 & -0.53312900\end{array}$ $\begin{array}{llll}1.82678200 & 0.37508900 & 0.28561000\end{array}$ $\begin{array}{lll}1.14840800 & -0.69725600 & -0.18876200\end{array}$ $\begin{array}{llll}3.10755100 & -0.02853800 & 0.24428200\end{array}$ $\begin{array}{llll}1.98787200 & -1.75980500 & -0.54715600\end{array}$ $\begin{array}{lll}-0.25012200 & -0.88146300 & -0.29002600\end{array}$ $\begin{array}{lll}4.41297500 & 0.59843800 & 0.47370100\end{array}$ $\begin{array}{llll}3.17385500 & -1.29733200 & -0.26514700\end{array}$ $\begin{array}{lll}-0.97338800 & -0.35124600 & -1.35798600\end{array}$ $\begin{array}{lll}-0.92556600 & -1.60633200 & 0.69315800\end{array}$ $\begin{array}{lll}4.60616900 & 0.64480500 & 1.54899000\end{array}$ $\begin{array}{llll}4.39148100 & 1.60600200 & 0.05590800\end{array}$ $\begin{array}{llll}5.35734600 & -0.38399800 & -0.26994000\end{array}$ $\begin{array}{llll}4.59660700 & -1.74238600 & -0.36945800\end{array}$ $\begin{array}{llll}-0.34874700 & 0.32928800 & -2.32122100\end{array}$ $\begin{array}{lll}-2.35433900 & -0.50779900 & -1.42340300\end{array}$ $\begin{array}{lll}-2.30140500 & -1.78311900 & 0.62761000\end{array}$ $\begin{array}{lll}-0.24950300 & -2.11277100 & 1.72926400\end{array}$ $\begin{array}{lll}6.31493600 & -0.48761700 & 0.24261100\end{array}$ $\begin{array}{llll}5.54862500 & -0.00277600 & -1.27655000\end{array}$ $\begin{array}{llll}4.79818600 & -2.27950300 & -1.29785300\end{array}$ $\begin{array}{lll}4.83965200 & -2.40818500 & 0.46633000\end{array}$ $\begin{array}{llll}-3.04933300 & 0.02812900 & -2.43523200\end{array}$ $-3.01468200-1.22697700-0.43158700$ $\begin{array}{lll}-2.94800000 & -2.46041100 & 1.58668400\end{array}$ $-4.34242600-1.37326700-0.48833700$ $\begin{array}{lll}-0.62965900 & 1.40252300 & 1.72607000\end{array}$
\end{abstract}


C (toluene)

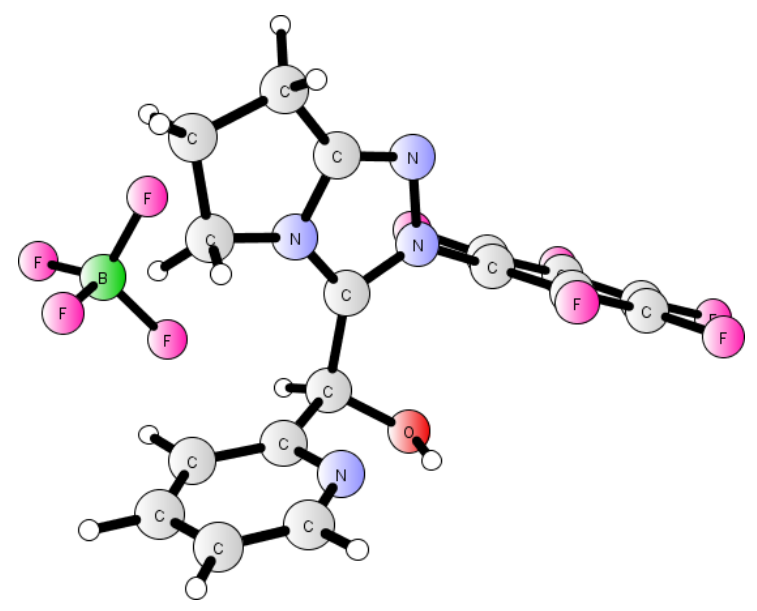

$\begin{array}{lllll}\text { C } & 0.63017100 & 0.79162600 & -0.89390900\end{array}$

H $\quad 0.93858200 \quad-0.05951200 \quad-1.51393500$

C $\quad 1.71645400 \quad 1.86869700 \quad-0.91806000$

C $\quad 3.02130100 \quad 1.61553900 \quad-1.33868600$

$\begin{array}{lllll}\text { C } & 2.13548600 & 4.11042200 & -0.61213200\end{array}$

C $\quad 3.91308100 \quad 2.69136200-1.38204500$

H $\quad 3.32941600 \quad 0.61308600 \quad-1.61778400$

C $\quad 3.46702300 \quad 3.96010900 \quad-1.01098700$

H $\quad 1.74293600 \quad 5.08323000 \quad-0.32625200$

H $\quad 4.93649300 \quad 2.53598200 \quad-1.71038600$

H $\quad 4.12797400 \quad 4.82065100 \quad-1.03748900$

$\begin{array}{lllll}\text { O } & -0.58023600 & 1.31398600 & -1.40118100\end{array}$

$\begin{array}{lllll}\text { C } & 0.38852900 & 0.22792500 & 0.50363000\end{array}$

N $\quad \begin{array}{llll}\text { N } & -0.79985600 & -0.16453700 & 1.01482000\end{array}$

$\begin{array}{llll}\mathrm{N} & 1.27995400 & -0.05936600 & 1.45930100\end{array}$

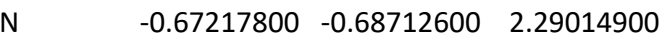

C $\quad-2.09975500 \quad-0.16165800 \quad 0.43151000$

$\begin{array}{lllll}\text { C } & 2.73903400 & 0.06499900 & 1.70481900\end{array}$

$\begin{array}{llll}\text { C } & 0.60700000 & -0.60628400 & 2.52584600\end{array}$

$\begin{array}{llll}\text { C } & -2.53888300 & -1.24836300 & -0.32597800\end{array}$

$\begin{array}{lllll}\text { C } & -2.98218300 & 0.88812300 & 0.68988000\end{array}$

$\begin{array}{llll}\mathrm{H} & 2.96124900 & 1.11596500 & 1.90788200\end{array}$

$\begin{array}{llll}H & 3.29936300 & -0.28340000 & 0.83924000\end{array}$

$\begin{array}{llll}\text { C } & 2.92180300 & -0.84767800 & 2.94389400\end{array}$

$\begin{array}{llll}\text { C } & 1.53618100 & -0.93375600 & 3.64676400\end{array}$

F $\quad-1.71721900 \quad-2.27211900-0.56759300$

$\begin{array}{llll}\text { C } & -3.83255900 & -1.27513600 & -0.84040300\end{array}$

$\begin{array}{lllll}C & -4.27557700 & 0.87095600 & 0.18242900\end{array}$

$\begin{array}{lllll}F & -2.57494900 & 1.93768400 & 1.41587300\end{array}$

H $\quad 3.69504700 \quad-0.45704000 \quad 3.60760500$

$\begin{array}{llll}H & 3.22412900 & -1.84076800 & 2.60528300\end{array}$

H $\quad 1.33298100 \quad-1.91818600 \quad 4.07316500$

H $\quad \begin{array}{llll}\text { H } & 1.42711000 & -0.19062100 & 4.44536000\end{array}$

F $\quad-4.24914800 \quad-2.31686100-1.56814300$

C $\quad-4.69922700 \quad-0.21527000 \quad-0.58258400$

F $\quad-\quad \begin{array}{llll}\text { C } & -11306000 & 1.88730500 & 0.42483500\end{array}$

F $\quad-5.94274500 \quad-0.23951200-1.06805100$

N $\quad \begin{array}{llll}1.27518600 & 3.08551700 & -0.56657000\end{array}$

H $\quad-0.57285400 \quad 2.26473800 \quad-1.17766400$

$\begin{array}{lllll}\text { B } & 3.10446100 & -2.44011400 & -1.08975400\end{array}$

F $\quad 3.65389500-3.58310700-1.67059700$

F $\quad 4.11842100-1.46368600-0.86394300$

F $\quad \begin{array}{llll}2.50213300 & -2.75068700 & 0.15523000\end{array}$

F $\quad 2.12357700 \quad-1.86863200 \quad-1.94257200$
D (toluene)

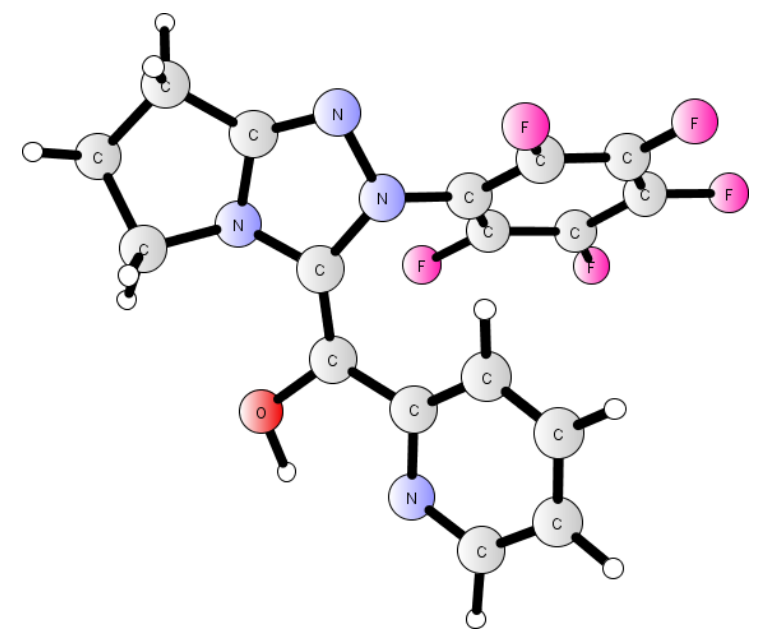

$\begin{array}{lll}-1.39919100 & 1.59151500 & 0.05389600\end{array}$

$\begin{array}{lll}-0.17981900 & 2.26890800 & -0.34153800\end{array}$

$\begin{array}{llll}0.76172700 & 1.79014800 & -1.28079300\end{array}$

$\begin{array}{llll}1.02999400 & 4.23689500 & -0.08196400\end{array}$

$\begin{array}{llll}1.87157800 & 2.56747700 & -1.57565000\end{array}$

$\begin{array}{llll}0.59283900 & 0.85817900 & -1.80307300\end{array}$

$\begin{array}{llll}2.03191500 & 3.81380700 & -0.95270300\end{array}$

$\begin{array}{lll}1.08513500 & 5.21228200 & 0.39639700\end{array}$

$\begin{array}{lll}2.59971700 & 2.21627300 & -2.30121900\end{array}$

$\begin{array}{llll}2.88978300 & 4.44519900 & -1.15669300\end{array}$

$\begin{array}{llll}-2.33241800 & 2.37985200 & 0.70811200\end{array}$

$\begin{array}{lll}-1.72401300 & 0.27393500 & -0.10452800\end{array}$

$\begin{array}{lll}-0.91901400 & -0.82316300 & -0.48160100\end{array}$

$\begin{array}{lll}-2.96852200 & -0.30432100 & 0.08882500\end{array}$

$\begin{array}{lll}-1.71332700 & -2.00969400 & -0.63909800\end{array}$

$0.40855700-1.02145200-0.07483800$

$\begin{array}{llll}-4.34057700 & 0.18800300 & 0.21959200\end{array}$

$\begin{array}{lll}-2.90043100 & -1.61805100 & -0.30358400\end{array}$

$\begin{array}{lll}0.88033800 & -0.68838200 & 1.20185400\end{array}$

$\begin{array}{llll}1.32996500 & -1.56871600 & -0.97742300\end{array}$

$\begin{array}{llll}-4.63307200 & 0.72223300 & -0.69285500\end{array}$

$\begin{array}{lll}-4.43094900 & 0.86673700 & 1.06624100\end{array}$

$\begin{array}{lll}-5.11536900 & -1.13999700 & 0.40118900\end{array}$

$-4.27158200-2.22083500-0.33101500$

$\begin{array}{llll}0.04178200 & -0.20690400 & 2.13103900\end{array}$

$\begin{array}{llll}2.21863400 & -0.84795900 & 1.54609000\end{array}$

$\begin{array}{llll}2.66252300 & -1.76204200 & -0.63524500\end{array}$

$\begin{array}{llll}0.93462500 & -1.87847100 & -2.22139000\end{array}$

$\begin{array}{lll}-6.13282400 & -1.07251400 & 0.01153000\end{array}$

$\begin{array}{lll}-5.17415500 & -1.38014900 & 1.46686500\end{array}$

$\begin{array}{lll}-4.31134800 & -3.20118000 & 0.14832600\end{array}$

$\begin{array}{lll}-4.58875800 & -2.34465900 & -1.37264500\end{array}$

$\begin{array}{llll}2.64407200 & -0.51180700 & 2.77369400\end{array}$

$\begin{array}{llll}3.11222900 & -1.39294300 & 0.62945800\end{array}$

$3.52365600-2.27616100-1.52745600$

$\begin{array}{llll}4.39875900 & -1.56455800 & 0.96283900\end{array}$

$\begin{array}{lll}-0.04433200 & 3.49813100 & 0.21830600\end{array}$

$\begin{array}{lll}-1.86557600 & 3.23136500 & 0.84189400\end{array}$ 

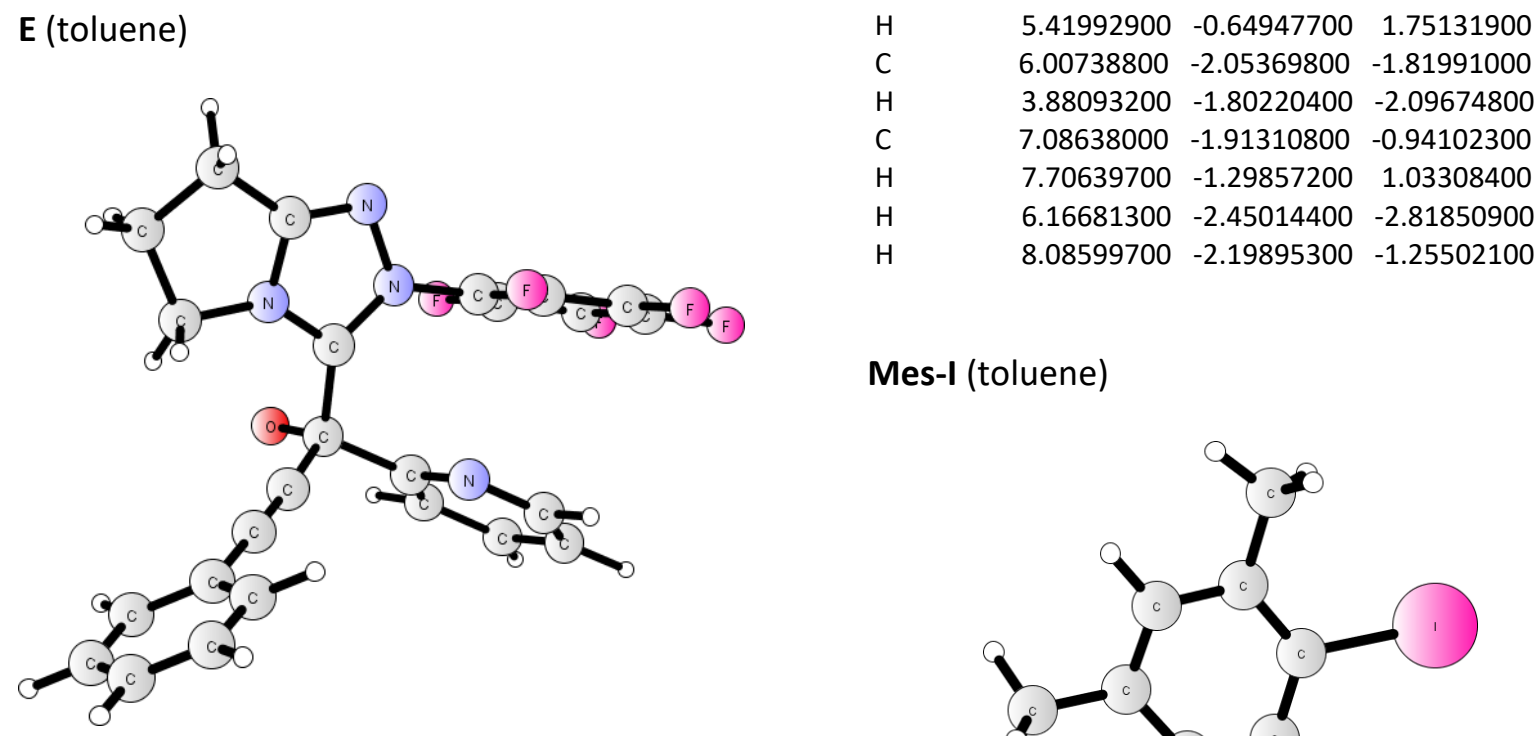

\begin{tabular}{lrrr}
$\mathrm{C}$ & 0.75488400 & 0.01254500 & 1.18734300 \\
$\mathrm{C}$ & -0.23584600 & -1.17206900 & 1.04476700 \\
$\mathrm{C}$ & -0.85858200 & -1.66166700 & 2.19164400 \\
$\mathrm{C}$ & -1.28807400 & -2.70811100 & -0.29768400 \\
$\mathrm{C}$ & -1.73981800 & -2.73520400 & 2.05886300 \\
$\mathrm{H}$ & -0.64219000 & -1.18079700 & 3.13827000 \\
$\mathrm{C}$ & -1.96153700 & -3.27223500 & 0.78899900 \\
$\mathrm{H}$ & -1.43793500 & -3.09453800 & -1.30374300 \\
$\mathrm{H}$ & -2.24815800 & -3.14293000 & 2.92794300 \\
$\mathrm{H}$ & -2.63992300 & -4.10602700 & 0.63784300 \\
$\mathrm{O}$ & 0.82557700 & 0.55141600 & 2.40397100 \\
$\mathrm{C}$ & 0.30676000 & 1.20550400 & 0.28697600 \\
$\mathrm{~N}$ & -0.90229000 & 1.59341700 & -0.18458300 \\
$\mathrm{~N}$ & 1.07106500 & 2.29929600 & 0.12548000 \\
$\mathrm{~N}$ & -0.91240000 & 2.92345100 & -0.62178000 \\
$\mathrm{C}$ & -2.08457800 & 0.83373200 & -0.34305600 \\
$\mathrm{C}$ & 2.43968900 & 2.70152200 & 0.47635000 \\
$\mathrm{C}$ & 0.31484300 & 3.30780500 & -0.40983000 \\
$\mathrm{C}$ & -2.93458600 & 0.58480700 & 0.73376000 \\
$\mathrm{C}$ & -2.41657900 & 0.32911100 & -1.60124400 \\
$\mathrm{H}$ & 3.13472800 & 2.26905700 & -0.24679700 \\
$\mathrm{H}$ & 2.67337900 & 2.33011800 & 1.47400000 \\
$\mathrm{C}$ & 2.33622300 & 4.24633500 & 0.37915300 \\
$\mathrm{C}$ & 1.13033200 & 4.55035600 & -0.56052900 \\
$\mathrm{~F}$ & -2.65187900 & 1.07623200 & 1.94178300 \\
$\mathrm{C}$ & -4.07815700 & -0.19021500 & 0.56663200 \\
$\mathrm{C}$ & -3.56577200 & -0.42908500 & -1.78210600 \\
$\mathrm{~F}$ & -1.60606900 & 0.54790200 & -2.64115400 \\
$\mathrm{H}$ & 3.26422500 & 4.68715600 & 0.01179800 \\
$\mathrm{H}$ & 2.13305700 & 4.65591800 & 1.37232600 \\
$\mathrm{H}$ & 0.57843300 & 5.44790100 & -0.27623400 \\
$\mathrm{H}$ & 1.44480700 & 4.66208500 & -1.60441400 \\
$\mathrm{~F}$ & -4.87727500 & -0.45069000 & 1.60951000 \\
$\mathrm{C}$ & -4.39284200 & -0.69228800 & -0.69258100 \\
$\mathrm{~F}$ & -3.86741400 & -0.93233900 & -2.98741000 \\
$\mathrm{~F}$ & -5.48660000 & -1.44397100 & -0.85505200 \\
$\mathrm{~N}$ & -0.44150300 & -1.67651800 & -0.17942600 \\
$\mathrm{C}$ & 2.07234300 & -0.45365700 & 0.63567200 \\
$\mathrm{C}$ & 3.18536800 & -0.79326800 & 0.28609700 \\
$\mathrm{C}$ & 4.49846200 & -1.17646900 & -0.12686700 \\
$\mathrm{C}$ & 5.59108600 & -1.03923300 & 0.75286500 \\
& 4.72204600 & -1.69041900 & -1.41992800 \\
& 6.87288900 & -1.40626600 & 0.34499800 \\
\hline
\end{tabular}

Mes-I (toluene)

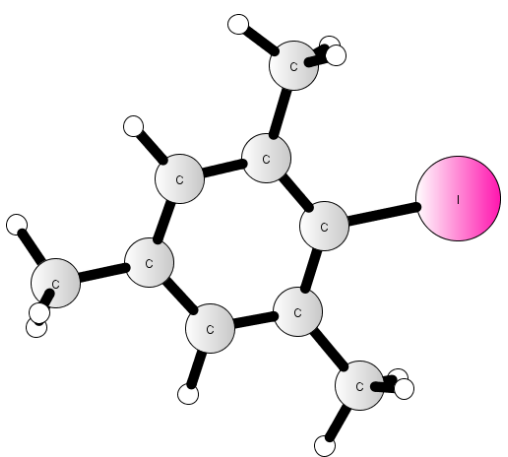

C $\quad-2.24649200 \quad-1.19649900 \quad-0.00591500$

C $\quad-0.84593800-1.23062000-0.00243100$

$\begin{array}{llll}\text { C } & -0.16549600 & 0.00146000 & -0.00003700\end{array}$

C $\quad-0.84206700 \quad 1.23278300-0.00234200$

$\begin{array}{llll}\text { C } & -2.24527600 & 1.20142500 & -0.00578700\end{array}$

$\begin{array}{llll}\text { C } & -2.96466000 & 0.00423500 & -0.00616000\end{array}$

$\mathrm{H} \quad-2.78630200-2.14065100 \quad-0.00936300$

$\mathrm{H} \quad \begin{array}{llll}\mathrm{H} & -2.78260700 & 2.14654600 & -0.00907400\end{array}$

$\begin{array}{llll}\text { C } & -0.13130200 & 2.56117900 & -0.00310800\end{array}$

$\begin{array}{llll}\mathrm{H} & 0.51145500 & 2.67133100 & 0.87746700\end{array}$

H $\quad 0.51297400 \quad 2.66974500 \quad-0.88278700$

H $\quad-0.85301300 \quad 3.38228100 \quad-0.00444500$

C $\quad-0.13600200-2.55948900-0.00306200$

H $\quad 0.50829100-2.66849300-0.88264400$

$\begin{array}{llll}\mathrm{H} & 0.50656100 & -2.66995900 & 0.87759100\end{array}$

H $\quad-0.85835700 \quad-3.38003100 \quad-0.00442600$

C $\quad-4.47341200 \quad-0.00166200 \quad 0.01031500$

H $\quad-4.85517000 \quad-0.32026700 \quad 0.98835700$

$\begin{array}{lllll}\mathrm{H} & -4.87838600 & 0.99331000 & -0.19607700\end{array}$

$\mathrm{H} \quad-4.87748000-0.69452900-0.73600300$

I $\quad 1.96520600 \quad-0.00124800 \quad 0.00174700$

NHC-1 (toluene)

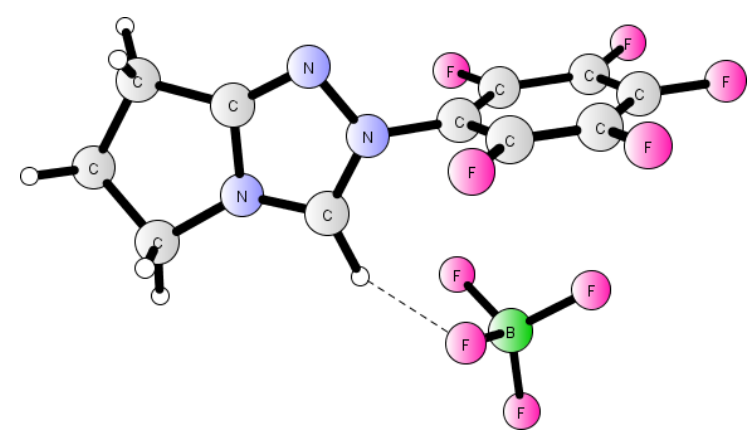

$\begin{array}{llll}N & 2.025514000 & -1.698297000 & -0.133982000\end{array}$ N $\quad \begin{array}{llll}1.170787000 & -0.648040000 & 0.150823000\end{array}$ 


$\begin{array}{lrrr}\text { C } & 1.830433000 & 0.489958000 & 0.400039000 \\ \text { H } & 1.352971000 & 1.436031000 & 0.636405000 \\ \text { N } & 3.119564000 & 0.180341000 & 0.278864000 \\ \text { C } & 4.430526000 & 0.841893000 & 0.413646000 \\ \text { H } & 4.647558000 & 0.967060000 & 1.477609000 \\ \text { H } & 4.413673000 & 1.816426000 & -0.073873000 \\ \text { C } & 5.359177000 & -0.189037000 & -0.278087000 \\ \text { H } & 6.345018000 & -0.207720000 & 0.187977000 \\ \text { H } & 5.482934000 & 0.085702000 & -1.328718000 \\ \text { C } & 4.638120000 & -1.567171000 & -0.184107000 \\ \text { H } & 4.807114000 & -2.197770000 & -1.058534000 \\ \text { H } & 4.944657000 & -2.130892000 & 0.704032000 \\ \text { C } & 3.209736000 & -1.154351000 & -0.047751000 \\ \text { C } & -0.236486000 & -0.824581000 & 0.115139000 \\ \text { F } & -0.177668000 & -1.007177000 & -2.240427000 \\ \text { C } & -0.884950000 & -0.998735000 & -1.107914000 \\ \text { F } & -2.887696000 & -1.314869000 & -2.326535000 \\ \text { C } & -2.263989000 & -1.151772000 & -1.154797000 \\ \text { F } & -4.325991000 & -1.266048000 & -0.015107000 \\ \text { C } & -3.000435000 & -1.122902000 & 0.027780000 \\ \text { F } & -3.078688000 & -0.922009000 & 2.383640000 \\ \text { C } & -2.364045000 & -0.944528000 & 1.253117000 \\ \text { F } & -0.368754000 & -0.632818000 & 2.470318000 \\ \text { C } & -0.983205000 & -0.798034000 & 1.291964000 \\ \text { B } & -0.925360000 & 2.606555000 & -0.242174000 \\ \text { F } & -0.152524000 & 1.951760000 & -1.240714000 \\ \text { F } & -2.174297000 & 1.978415000 & -0.127748000 \\ \text { F } & -1.059849000 & 3.960876000 & -0.545265000 \\ \text { F } & -0.217585000 & 2.460306000 & 0.999824000\end{array}$

TMEDA (toluene)

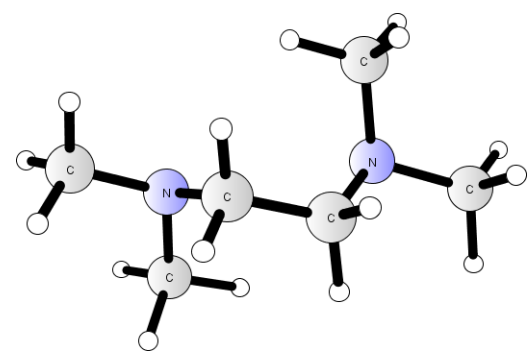

$\begin{array}{lrrr}\text { C } & -0.704811000 & 0.299158000 & 0.954348000 \\ \text { H } & -0.647331000 & 1.385005000 & 1.089499000 \\ \text { H } & -1.219252000 & -0.099416000 & 1.854186000 \\ \text { C } & 0.704964000 & -0.299381000 & 0.954330000 \\ \text { H } & 1.219431000 & 0.099202000 & 1.854157000 \\ \text { H } & 0.647542000 & -1.385228000 & 1.089467000 \\ \text { N } & 1.482099000 & -0.049306000 & -0.255596000 \\ \text { N } & -1.482067000 & 0.049237000 & -0.255577000 \\ \text { C } & -1.609597000 & -1.367234000 & -0.566806000 \\ \text { H } & -2.097834000 & -1.942716000 & 0.246133000 \\ \text { H } & -2.212605000 & -1.485964000 & -1.472492000 \\ \text { H } & -0.625352000 & -1.799093000 & -0.761276000 \\ \text { C } & -2.784409000 & 0.693654000 & -0.171152000 \\ \text { H } & -3.325519000 & 0.563375000 & -1.113971000 \\ \text { H } & -3.415070000 & 0.286777000 & 0.645501000 \\ \text { H } & -2.658337000 & 1.767578000 & 0.003567000 \\ \text { C } & 1.609257000 & 1.367225000 & -0.566729000 \\ \text { H } & 2.097360000 & 1.942764000 & 0.246253000 \\ \text { H } & 2.212232000 & 1.486187000 & -1.472407000 \\ \text { H } & 0.624902000 & 1.798858000 & -0.761154000\end{array}$

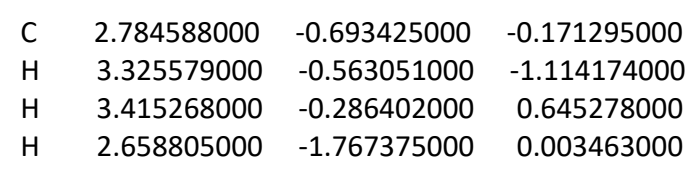

$\mathrm{TMEDAH}^{+} \mathrm{BF}_{4}^{-}$(toluene)

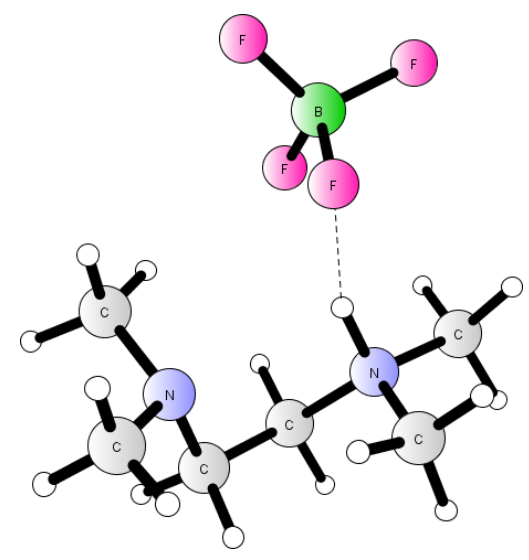

$\begin{array}{rrr}-2.44536500 & 0.10668100 & 0.71079900 \\ -3.21968500 & 0.64312800 & 0.15371500 \\ -2.92112600 & -0.24736100 & 1.64506100 \\ -1.33639300 & 1.07836300 & 1.10821500 \\ -1.76234300 & 1.98583900 & 1.54493800 \\ -0.64422100 & 0.63613200 & 1.82538800 \\ -0.48772600 & 1.49643600 & -0.06285400 \\ -1.95239300 & -0.98238800 & -0.12207700 \\ -1.17596400 & -1.96695300 & 0.63243100 \\ -1.79757000 & -2.49858100 & 1.37735200 \\ -0.75530200 & -2.70139900 & -0.05880200 \\ -0.33941900 & -1.49371000 & 1.14785600 \\ -3.03102800 & -1.62699300 & -0.86352900 \\ -2.60951700 & -2.38251200 & -1.53264800 \\ -3.76686700 & -2.12447400 & -0.20369600 \\ -3.56282900 & -0.88954500 & -1.47404600 \\ -1.27236700 & 2.00607200 & -1.22411900 \\ -1.90014800 & 2.83723100 & -0.89717700 \\ -0.56985000 & 2.34387400 & -1.98641400 \\ -1.87574400 & 1.19381100 & -1.62372900 \\ 0.54577000 & 2.48891800 & 0.36341700 \\ 1.22897200 & 2.65872300 & -0.46854900 \\ 0.04440700 & 3.41795900 & 0.64078800 \\ 1.09800300 & 2.07861900 & 1.20666500 \\ 0.02008200 & 0.65336500 & -0.39747200 \\ 1.69197300 & -0.27266300 & 1.16708300 \\ 2.29232400 & -0.55796100 & -0.09047700 \\ 1.28281300 & -0.31835200 & -1.09526100 \\ 3.35889700 & 0.32057600 & -0.31312300 \\ 2.69347700 & -1.88913300 & -0.14932300\end{array}$ 
TMEDAH $^{+} \mathrm{TsO}^{-}$(toluene)

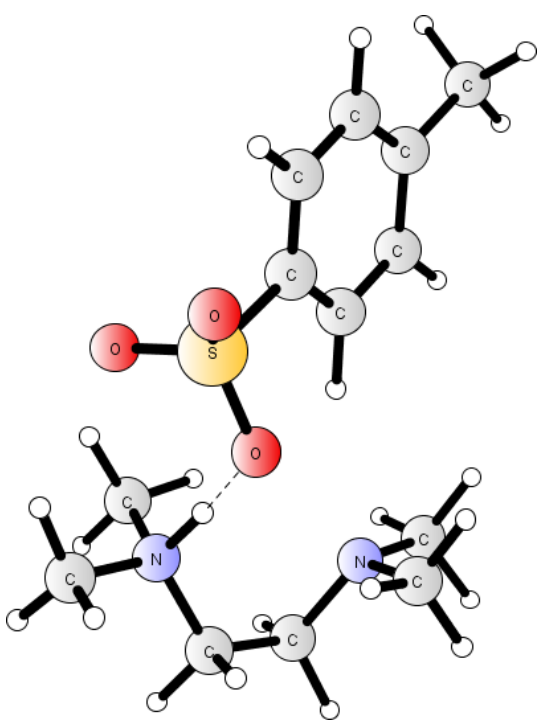

$\begin{array}{llll}\text { C } & -3.08997900 & 1.87732000 & 0.10095800\end{array}$

$\begin{array}{llll}\mathrm{H} & -3.06865900 & 2.24111700 & 1.13280200\end{array}$

H $\quad-3.85286000 \quad 2.48229900 \quad-0.42761200$

$\begin{array}{llll}\text { C } & -3.58804400 & 0.43488500 & 0.08329000\end{array}$

$\begin{array}{lllll}\mathrm{H} & -4.51617500 & 0.36841900 & 0.65944800\end{array}$

H $\quad-3.79736200 \quad 0.09339600 \quad-0.93295500$

$\begin{array}{llll}\mathrm{N} & -2.61969000 & -0.55321500 & 0.66123700\end{array}$

$\begin{array}{lllll}\mathrm{N} & & -1.75864200 & 2.04994000 & -0.46649900\end{array}$

C $\quad-1.71993500 \quad 1.81099700 \quad-1.90807700$

H $\quad-2.37832500 \quad 2.50644000 \quad-2.46224000$

H $\quad-0.69632700 \quad 1.94247200 \quad-2.26716300$

H $\quad-2.00452200 \quad 0.78408900 \quad-2.14041600$

C $\quad-1.22120300 \quad 3.36750700 \quad-0.14200800$

H $\quad-0.20472900 \quad 3.45395400 \quad-0.53628800$

H $\quad-1.82305900 \quad 4.19215100 \quad-0.56851600$

$\begin{array}{llll}H & -1.18030500 & 3.49933000 & 0.94427600\end{array}$

$\begin{array}{llll}\text { C } & -2.05494800 & -0.15028100 & 1.97882000\end{array}$

H $\quad-2.86832300 \quad-0.00578900 \quad 2.69427800$

$\begin{array}{llll}H & -1.38385000 & -0.94419300 & 2.30400400\end{array}$

$\begin{array}{llll}\text { H } & -1.48540000 & 0.76823800 & 1.85155000\end{array}$

C $\quad-3.23712700 \quad-1.90873000 \quad 0.73914200$

H $\quad-2.46064100 \quad-2.61364500 \quad 1.03519800$

H $\quad-4.05268400 \quad-1.89390000 \quad 1.46581100$

H $\quad-3.61632900-2.17795100 \quad-0.24771500$

H $\quad-1.80459700 \quad-0.66428400 \quad-0.02599900$

O $\quad-0.72897600-1.12466400-1.08888900$

S $\quad 0.38260100-1.93383000-0.44239500$

$\begin{array}{lllll}0 & -0.03799800 & -2.39547700 & 0.91694300\end{array}$

$\begin{array}{lllll}0 & 0.92519000 & -2.98918900 & -1.32519700\end{array}$

C $\quad 1.70535500 \quad-0.74191300 \quad-0.17424800$

C $\quad 3.02794000 \quad-1.18640300-0.10886200$

$\begin{array}{lllll}\text { C } & & 1.39849300 & 0.60328400 & 0.03117100\end{array}$

$\begin{array}{llll}\text { C } & 4.04577300 & -0.27361200 & 0.16329200\end{array}$

H $\quad 3.25330700 \quad-2.23335500 \quad-0.28202100$

C $\quad \begin{array}{llll}2.42969700 & 1.50593400 & 0.30419800\end{array}$

H $\quad 0.36895000 \quad 0.94183600 \quad-0.03917300$

$\begin{array}{llll}\text { C } & 3.76477800 & 1.08573100 & 0.37646200\end{array}$

$\begin{array}{llll}\mathrm{H} & 5.07551400 & -0.61994800 & 0.20785000\end{array}$

$\begin{array}{llll}\mathrm{H} & 2.19338500 & 2.55580300 & 0.45950000\end{array}$

$\begin{array}{llll}\text { C } & 4.87871600 & 2.06167200 & 0.66429100\end{array}$

$\begin{array}{llll}\text { H } & 4.49249900 & 3.07229900 & 0.82635800\end{array}$
$\begin{array}{llll}\mathrm{H} & 5.44196700 & 1.76805300 & 1.55797400\end{array}$

H $\quad 5.59241700 \quad 2.10366300 \quad-0.16721500$

TS1 (toluene)

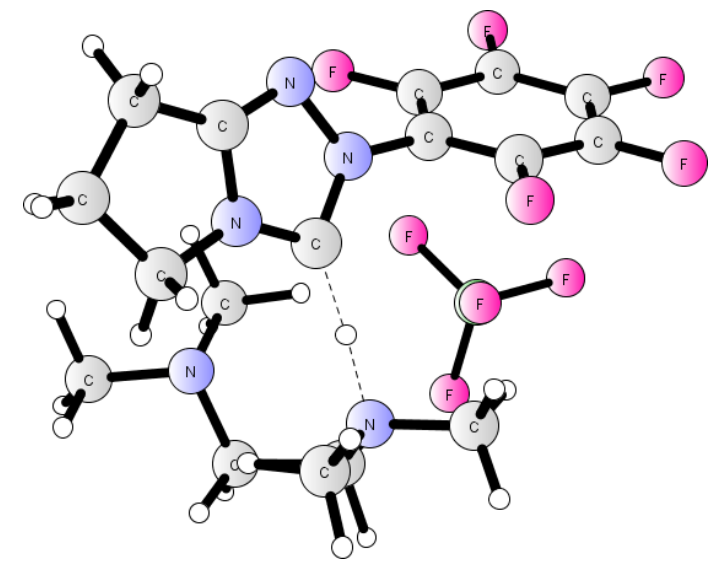

$\begin{array}{lll}1.44403400 & 0.51207200 & 1.16196000\end{array}$

$\begin{array}{lll}1.48295000 & 1.66025500 & 1.78372100\end{array}$

$\begin{array}{lll}1.30203100 & 2.81156500 & 0.85442700\end{array}$

$\begin{array}{llll}2.78598000 & 1.67865700 & 2.47325200\end{array}$

$\begin{array}{lll}0.37755700 & 1.62377700 & 2.76801900\end{array}$

$\begin{array}{lll}2.37794000 & 2.92810200 & -0.22017200\end{array}$

$\begin{array}{lll}1.29749000 & 3.73953700 & 1.44230900\end{array}$

$\begin{array}{lll}0.31318400 & 2.70327900 & 0.41129100\end{array}$

$\begin{array}{lll}2.90940500 & 2.60228300 & 3.05140200\end{array}$

$\begin{array}{llll}2.83863100 & 0.82652900 & 3.15625600\end{array}$

$\begin{array}{llll}3.59373000 & 1.59823600 & 1.74542600\end{array}$

$\begin{array}{lll}0.46734300 & 0.71921900 & 3.37423100\end{array}$

$\begin{array}{llll}0.41888100 & 2.50093600 & 3.42456600\end{array}$

$\begin{array}{lll}-0.57286000 & 1.61408500 & 2.23507400\end{array}$

$\begin{array}{lll}3.33961500 & 3.18976800 & 0.23372700\end{array}$

$\begin{array}{llll}2.09030800 & 3.78336800 & -0.86051000\end{array}$

$\begin{array}{llll}2.57096300 & 1.70849400 & -1.00611900\end{array}$

$\begin{array}{lll}1.39046700 & 1.38106300 & -1.81103700\end{array}$

$\begin{array}{llll}3.74611500 & 1.83401200 & -1.86230000\end{array}$

$\begin{array}{llll}1.14401900 & 2.17757700 & -2.53434500\end{array}$

$\begin{array}{llll}1.57415600 & 0.45811500 & -2.36854900\end{array}$

$\begin{array}{llll}0.51593900 & 1.22665800 & -1.18117300\end{array}$

$\begin{array}{llll}3.90770500 & 0.89782100 & -2.40667800\end{array}$

$\begin{array}{llll}3.64647300 & 2.64394700 & -2.60910900\end{array}$

$\begin{array}{llll}4.63590800 & 2.04215200 & -1.25755000\end{array}$

$\begin{array}{lll}1.54602800 & -0.75827300 & 0.59449200\end{array}$

$\begin{array}{llll}0.63448900 & -1.63652500 & 0.11955200\end{array}$

$\begin{array}{lll}2.70650500 & -1.35739100 & 0.26887000\end{array}$

$\begin{array}{llll}1.18806800 & -2.76230700 & -0.49437200\end{array}$

$\begin{array}{lll}-0.77353800 & -1.49770700 & 0.13793000\end{array}$

$\begin{array}{llll}4.13328900 & -1.05009900 & 0.41011600\end{array}$

$\begin{array}{llll}2.46654100 & -2.54579100 & -0.37845500\end{array}$

$\begin{array}{lll}-1.48682200 & -1.41142300 & -1.05898700\end{array}$

$\begin{array}{lll}-1.47253800 & -1.43892400 & 1.34235700\end{array}$

$\begin{array}{llll}4.44218100 & -1.23365800 & 1.44323800\end{array}$

$\begin{array}{llll}4.30761500 & -0.00635400 & 0.15254600\end{array}$

$\begin{array}{llll}4.77001200 & -2.05186600 & -0.58827900\end{array}$

$\begin{array}{llll}3.74859100 & -3.21801700 & -0.74808800\end{array}$

$\begin{array}{llll}-0.83575100 & -1.44848600 & -2.22675800\end{array}$

$\begin{array}{lll}-2.86960000 & -1.27488800 & -1.05535800\end{array}$

$\begin{array}{lll}-2.85146700 & -1.28029500 & 1.35859200\end{array}$ 


$\begin{array}{lrrr}\text { F } & -0.81163700 & -1.53568700 & 2.51003800 \\ \text { H } & 5.74390100 & -2.40109600 & -0.24179900 \\ \text { H } & 4.91024000 & -1.55809800 & -1.55367600 \\ \text { H } & 3.72865200 & -3.63355300 & -1.75715400 \\ \text { H } & 3.95513300 & -4.03764900 & -0.05064100 \\ \text { F } & -3.54564400 & -1.20413000 & -2.20503700 \\ \text { C } & -3.55004400 & -1.20010900 & 0.15707200 \\ \text { F } & -3.51018500 & -1.21438600 & 2.52500400 \\ \text { F } & -4.87705200 & -1.05830500 & 0.16932900 \\ \text { F } & -1.56978400 & 1.43345500 & 0.26536800 \\ \text { B } & -2.26654100 & 2.14011600 & -0.76536300 \\ \text { F } & -1.98577900 & 1.51635400 & -1.99761000 \\ F & -3.64271200 & 2.09120800 & -0.49571600 \\ \text { F } & -1.80401600 & 3.47196200 & -0.78096000\end{array}$

TS2 (toluene)

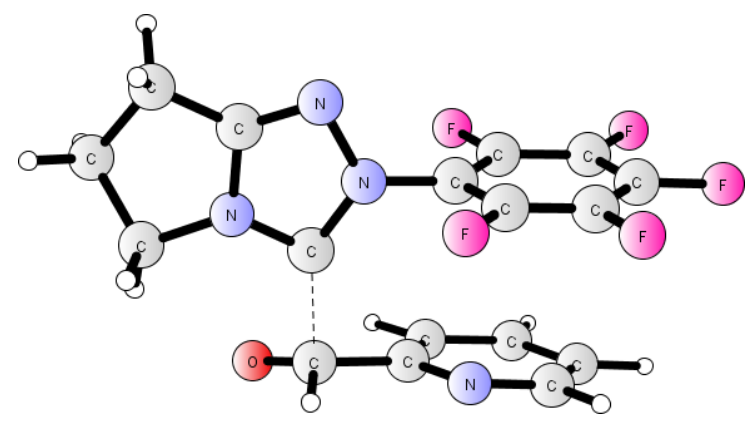

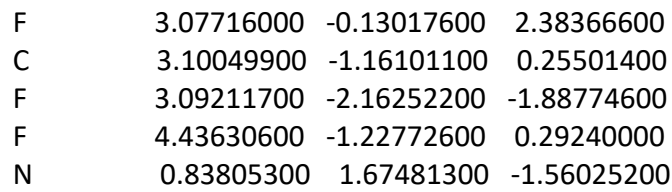

TS3 (toluene)

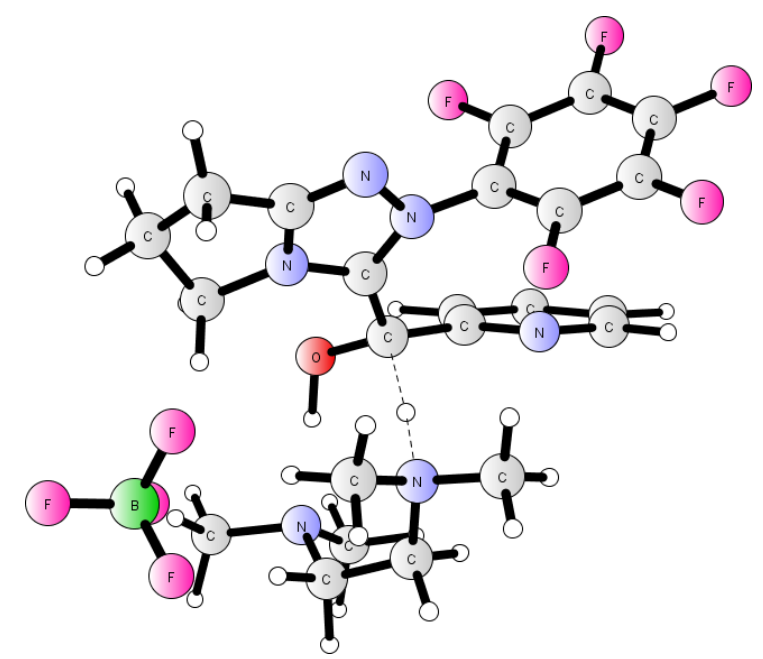

$\begin{array}{llll}\mathrm{H} & 0.70910100 & 0.97792700 & 0.62531000\end{array}$

C $\quad-1.14246100 \quad 1.66812100-0.62051100$

C $\quad-1.40028600 \quad 2.56732900 \quad-1.67205500$

$\begin{array}{lllll}\text { C } & -2.93190000 & 2.49839800 & 0.58428700\end{array}$

C $\quad-2.47460200 \quad 3.44659600 \quad-1.56353500$

H $\quad-0.76155700 \quad 2.55843100 \quad-2.54740200$

C $\quad-3.26157200 \quad 3.42148900 \quad-0.40820400$

$\mathrm{H} \quad-3.51323400 \quad 2.44818000 \quad 1.50363100$

$\begin{array}{llll}H & -2.69720500 & 4.14066500 & -2.36953700\end{array}$

$\mathrm{H} \quad-4.10140700 \quad 4.09638600 \quad-0.27630800$

$\begin{array}{lllll}0 & 1.01224900 & 1.17306100 & -1.63576500\end{array}$

C $\quad-0.11436100-0.67116900-0.76707500$

N $\quad-1.13642600-1.50393200-0.37470200$

N $\quad 0.84264800 \quad-1.53949200 \quad-1.19541800$

N $\quad-0.80603200 \quad-2.85963500-0.51602900$

C $\quad-2.48213900-1.22677800-0.03694400$

C $\quad 2.20870500 \quad-1.49507000 \quad-1.77264200$

C $\quad 0.39523500 \quad-2.82363500 \quad-1.00709000$

C $\quad-3.43235200-0.97830100-1.03005200$

C $\quad-2.91105400 \quad-1.30721500 \quad 1.28951000$

H $\quad 2.92813500 \quad-1.25977200 \quad-0.98681600$

H $\quad 2.25928300 \quad-0.74077100 \quad-2.55294900$

C $\quad 2.37533300 \quad-2.94622800 \quad-2.28634100$

C $\quad 1.42881000-3.82133800-1.41878000$

F $\quad-3.05873300 \quad-0.92484800 \quad-2.31538900$

$\begin{array}{llll}\text { C } & -4.77094400 & -0.77635000 & -0.70907000\end{array}$

$\begin{array}{llll}\text { C } & -4.24599000 & -1.11436700 & 1.62469500\end{array}$

$\begin{array}{lllll}\text { F } & -2.02684400 & -1.55740000 & 2.26307400\end{array}$

$\begin{array}{llll}F & -2.02684400 & -1.55740000 & 2.26307400 \\ H & 3.41505500 & -3.26814000 & -2.21161100\end{array}$

H $\quad 2.06951200 \quad-3.00299300 \quad-3.33588700$

H $\quad 1.00075900 \quad-4.67033300 \quad-1.95564100$

H $\quad 1.94293100-4.20366500 \quad-0.52952400$

F $\quad-5.67061300 \quad-0.52593700 \quad-1.67047300$

C $\quad-5.17605700-0.84715300 \quad 0.62155500$

F $\quad-4.64205200 \quad-1.17583100 \quad 2.90402000$ 


$\begin{array}{lrrr}\text { F } & -6.46095600 & -0.65484800 & 0.93823700 \\ \text { N } & -1.90200100 & 1.64322700 & 0.49276600 \\ \text { H } & 1.65452600 & 1.81397500 & -1.20724300 \\ \text { N } & 2.78600000 & 2.97233700 & -0.58306500 \\ \text { C } & 3.19080900 & 2.75126200 & 0.81872400 \\ \text { C } & 2.18349400 & 4.29870100 & -0.77992100 \\ \text { C } & 3.94685400 & 2.81146600 & -1.47721900 \\ \text { C } & 2.04656700 & 2.50947300 & 1.80553400 \\ \text { H } & 3.74495200 & 3.62983700 & 1.19265800 \\ \text { H } & 3.89263200 & 1.91491000 & 0.84129700 \\ \text { H } & 2.89447900 & 5.10844900 & -0.54257300 \\ \text { H } & 1.87359900 & 4.40547100 & -1.82344600 \\ \text { H } & 1.29634800 & 4.42287800 & -0.15406300 \\ \text { H } & 3.62548900 & 2.93752900 & -2.51545700 \\ \text { H } & 4.73354100 & 3.55452400 & -1.26507400 \\ \text { H } & 4.37163100 & 1.81210900 & -1.35885900 \\ \text { H } & 1.26645700 & 3.26869700 & 1.69993900 \\ \text { H } & 2.46240700 & 2.61205700 & 2.81694300 \\ \text { N } & 1.36006000 & 1.17952200 & 1.74555400 \\ \text { C } & 2.30653600 & 0.04220400 & 1.86615500 \\ \text { C } & 0.35796000 & 1.11465400 & 2.83932800 \\ \text { H } & 2.91039800 & 0.13877700 & 2.77508900 \\ \text { H } & 1.73632600 & -0.88670200 & 1.92322600 \\ \text { H } & 2.96960600 & 0.00095100 & 1.00513900 \\ \text { H } & -0.20755800 & 0.18575500 & 2.75855300 \\ \text { H } & 0.86361800 & 1.14535100 & 3.81186300 \\ \text { H } & -0.33401700 & 1.95262900 & 2.75404400 \\ \text { B } & 5.39743900 & -1.45869100 & 0.67750400 \\ \text { F } & 4.98431200 & -0.34156600 & -0.11031700 \\ \text { F } & 6.49223900 & -2.08471700 & 0.06445800 \\ \text { F } & 4.30745100 & -2.36574000 & 0.76314200 \\ \text { F } & 5.73532300 & -1.00799000 & 1.96820300\end{array}$

TS4 (toluene)

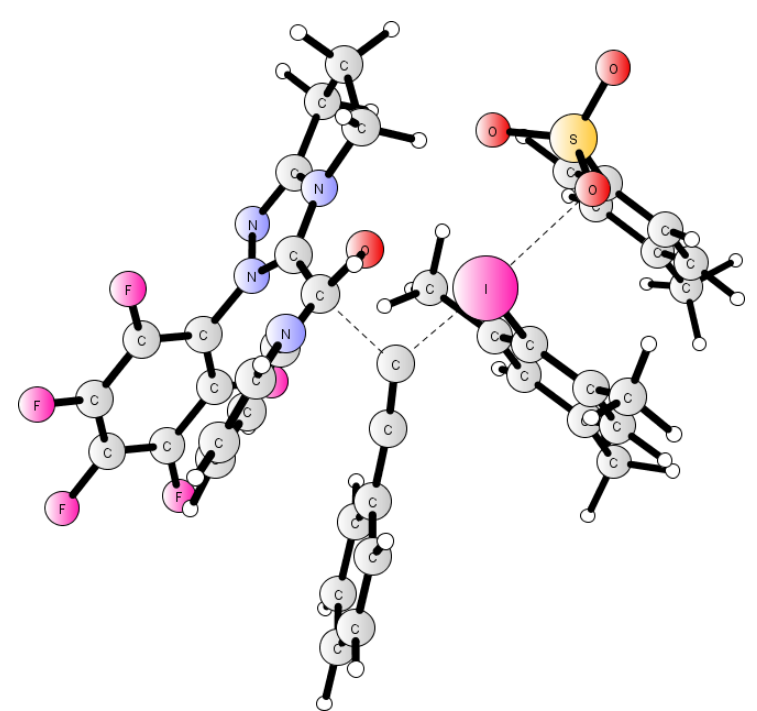

$\begin{array}{lll}5.67919500 & 0.81024600 & 1.74598100\end{array}$ $\begin{array}{lll}6.27943300 & -0.68116800 & 3.68176800\end{array}$ $\begin{array}{lll}1.06675200 & -2.61657700 & 1.86064700\end{array}$ $\begin{array}{llll}1.51866900 & -2.04233100 & -0.33131500\end{array}$ $\begin{array}{lll}1.92319900 & -1.42348500 & -1.49628900\end{array}$ $\begin{array}{llll}0.51061500 & -2.86396000 & -0.75274400\end{array}$ $\begin{array}{llll}1.17139400 & -1.83684500 & -2.60646600\end{array}$ $3.04366100-0.61430100-1.74541700$ $\begin{array}{llll}-0.35914600 & -3.92594200 & -0.19403600\end{array}$ $\begin{array}{llll}0.33210100 & -2.69189200 & -2.10332600\end{array}$ $4.34323300-1.10370500-1.58860800$ $\begin{array}{llll}2.87407100 & 0.69651100 & -2.20332400\end{array}$ $\begin{array}{lll}-1.17077500 & -3.46636500 & 0.36849900\end{array}$ $\begin{array}{llll}0.22102900 & -4.58582400 & 0.44633000\end{array}$ $\begin{array}{lll}-0.89168900 & -4.60599300 & -1.47706900\end{array}$ $-0.78872600-3.54008900-2.60073000$ $\begin{array}{llll}4.53681500 & -2.36582700 & -1.18485300\end{array}$ $\begin{array}{llll}5.44676300 & -0.29034100 & -1.81785600\end{array}$ $\begin{array}{llll}3.97051200 & 1.51375700 & -2.45244400\end{array}$ $\begin{array}{llll}1.64444900 & 1.17814000 & -2.40471300\end{array}$ $\begin{array}{lll}1.91995500 & -4.93741700 & -1.33341100\end{array}$ $\begin{array}{llll}-0.26828600 & -5.46997400 & -1.72732500\end{array}$ $\begin{array}{lll}-0.59627200 & -3.95729300 & -3.59038200\end{array}$ $\begin{array}{lll}-1.70228000 & -2.93743900 & -2.63561600\end{array}$ $6.68651100-0.75871200-1.62179500$ $\begin{array}{llll}5.25864900 & 1.01995700 & -2.24987000\end{array}$ $\begin{array}{llll}3.79751500 & 2.76808800 & -2.88506900\end{array}$ $\begin{array}{llll}6.31621700 & 1.80771700 & -2.46918500\end{array}$ $\begin{array}{lll}3.39900500 & -2.14536800 & 2.72641800\end{array}$ $\begin{array}{lll}1.67558400 & -2.80786900 & 2.61462800\end{array}$ $\begin{array}{lll}-1.19806400 & -0.77684000 & 1.64791100\end{array}$ $\begin{array}{lll}-2.10158900 & 0.99856100 & 0.92639100\end{array}$ $\begin{array}{llll}0.77648800 & 0.05436100 & 1.29595200\end{array}$ $-3.78155400-1.69539900 \quad 1.58693300$ $\begin{array}{lll}-2.66851300 & 1.88332300 & 1.85500200\end{array}$ $\begin{array}{llll}-2.07450300 & 1.23321600 & -0.45748000\end{array}$ $\begin{array}{lll}1.22496900 & 1.21035500 & 1.27869000\end{array}$ $\begin{array}{lll}-4.26219000 & -2.13802600 & 0.22343800\end{array}$ $\begin{array}{llll}-3.23058900 & 3.05911300 & 1.34201700\end{array}$ $\begin{array}{lll}-2.70527100 & 1.61703400 & 3.33760000\end{array}$ $\begin{array}{lll}-2.65017800 & 2.42782900 & -0.90376400\end{array}$ $\begin{array}{llll}-1.46368400 & 0.27358600 & -1.44127800\end{array}$ $\begin{array}{lll}1.86161900 & 2.47062500 & 1.22692700\end{array}$ $-3.12557300-2.51656200-0.67441300$ $\begin{array}{llll}-5.34223200 & -3.15169400 & 0.29567000\end{array}$ $\begin{array}{lll}-4.97943200 & -0.65781300 & -0.51234800\end{array}$ $\begin{array}{llll}-3.22764400 & 3.34905400 & -0.02581300\end{array}$ $\begin{array}{lll}-3.68534200 & 3.76082900 & 2.03645300\end{array}$ $\begin{array}{lll}-3.26346300 & 0.70268100 & 3.56609200\end{array}$ $\begin{array}{lll}-1.69617700 & 1.49981600 & 3.74749100\end{array}$ $\begin{array}{lll}-3.18681000 & 2.44680000 & 3.86065600\end{array}$ $\begin{array}{llll}-2.65709500 & 2.62965900 & -1.97124500\end{array}$ $\begin{array}{llll}-0.39934100 & 0.13334500 & -1.23514400\end{array}$ $\begin{array}{lll}-1.95763600 & -0.70121500 & -1.38705200\end{array}$ $\begin{array}{llll}-1.55826500 & 0.65686000 & -2.45981600\end{array}$ $\begin{array}{lll}1.78354600 & 3.28063900 & 0.06852900\end{array}$ $\begin{array}{lll}2.61140000 & 2.94748900 & 2.33049700\end{array}$ $\begin{array}{lll}-5.57797100 & 0.30206300 & 0.30576100\end{array}$ $\begin{array}{llll}-4.97105000 & -0.49579700 & -1.89725500\end{array}$ $\begin{array}{llll}-3.82038000 & 4.63445700 & -0.54375400\end{array}$ $\begin{array}{llll}2.44299300 & 4.50701500 & 0.01705000\end{array}$ $\begin{array}{lll}1.19610600 & 2.94056300 & -0.77636100\end{array}$ $\begin{array}{lll}3.26150700 & 4.17639500 & 2.26555300\end{array}$ 


$\begin{array}{lrrr}\text { H } & 2.67908700 & 2.33648900 & 3.22502200 \\ \mathrm{C} & -6.16831600 & 1.42472100 & -0.27007000 \\ \mathrm{H} & -5.56180600 & 0.17378000 & 1.38198000 \\ \mathrm{C} & -5.56299400 & 0.63564100 & -2.46226500 \\ \mathrm{H} & -4.49271500 & -1.24124800 & -2.52325100 \\ \mathrm{H} & -4.64173400 & 4.98050300 & 0.09128400 \\ \mathrm{H} & -3.06413300 & 5.42971900 & -0.56372600 \\ \mathrm{H} & -4.19784600 & 4.51530800 & -1.56341000 \\ \mathrm{C} & 3.18866800 & 4.96388500 & 1.10911900 \\ \mathrm{H} & 2.37306100 & 5.10950800 & -0.88432900 \\ \mathrm{H} & 3.83218900 & 4.52284800 & 3.12297100 \\ \mathrm{C} & -6.17475300 & 1.60898600 & -1.66095300 \\ \mathrm{H} & -6.62105500 & 2.17716100 & 0.37073500 \\ \mathrm{H} & -5.54784000 & 0.76365300 & -3.54178700 \\ \mathrm{H} & 3.70169900 & 5.91959100 & 1.06280100 \\ \mathrm{C} & -6.83553300 & 2.82069200 & -2.26973000 \\ \mathrm{H} & -6.54224200 & 2.95411100 & -3.31537900 \\ \mathrm{H} & -7.92854100 & 2.72657800 & -2.24225500 \\ \mathrm{H} & -6.57680800 & 3.73324600 & -1.72249000\end{array}$

TS5 (toluene)

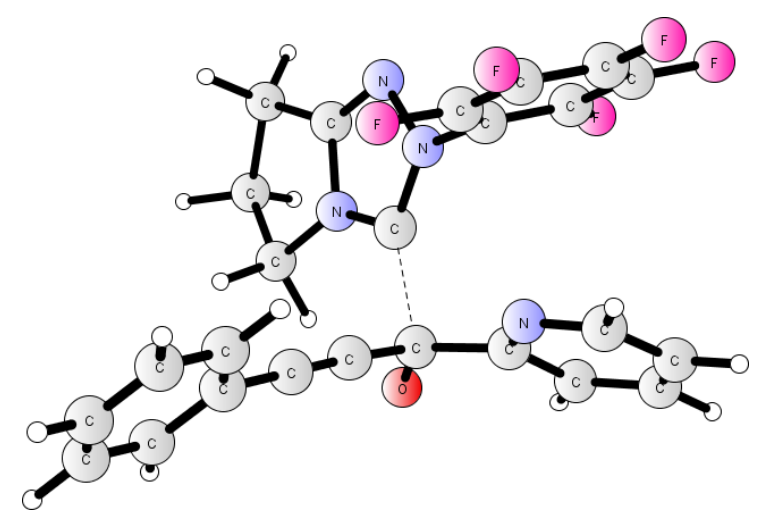

C

$\begin{array}{rrr}-2.20609500 & -2.06000800 & -1.67656500 \\ -0.08299800 & -1.13278300 & -2.07421700 \\ 2.33481400 & 5.41789800 & -1.26517900 \\ 0.81549900 & 5.59910700 & -0.37944700 \\ -0.16141500 & 5.06679000 & -2.50670300 \\ 1.24886800 & 4.13500200 & -3.02500000 \\ -5.14886900 & -0.60973500 & -0.10427600 \\ -3.50063000 & -1.92478600 & -1.17998500 \\ -1.82883800 & -3.20901300 & -2.25447300 \\ -4.36085900 & -2.94460100 & -1.27553000 \\ -0.55574900 & -1.08112500 & 1.77542300 \\ 1.92760300 & 0.10140900 & 1.10759500 \\ 2.90134300 & -0.50797600 & 0.70730800 \\ 4.03115000 & -1.24765900 & 0.23520900 \\ 5.34230100 & -0.79271900 & 0.48752100 \\ 3.85228900 & -2.44482800 & -0.48913100 \\ 6.44120900 & -1.51727800 & 0.02578700 \\ 5.48577100 & 0.12504700 & 1.04975100 \\ 4.95691700 & -3.16251300 & -0.94772100 \\ 2.84504400 & -2.80051800 & -0.68269800 \\ 6.25375100 & -2.70287700 & -0.69316800 \\ 7.44588800 & -1.15683300 & 0.22927200 \\ 4.80498300 & -4.08372500 & -1.50352900 \\ 7.11182500 & -3.26533900 & -1.05059200\end{array}$

TS $\beta$ (toluene)

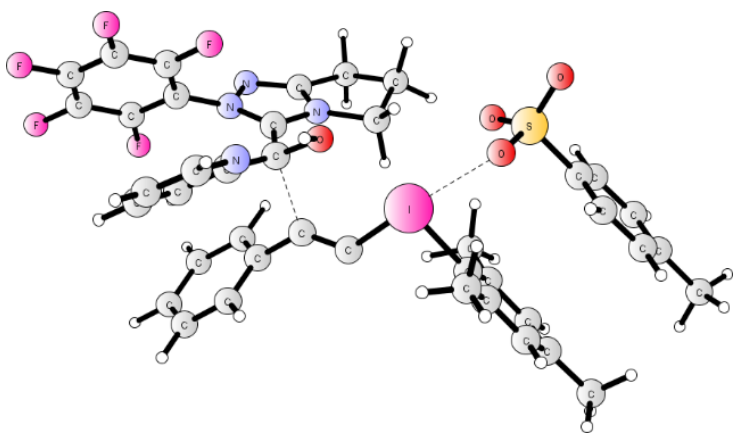
C 西 H H $\mathrm{O}$ C $\mathrm{N}$
$\begin{array}{lll}-1.87658600 & -0.02852800 & -0.58371800\end{array}$ $\begin{array}{llll}-2.87350000 & 0.82128200 & -1.28344000\end{array}$ $\begin{array}{llll}-3.92347100 & 1.52892600 & -0.67592800\end{array}$ $\begin{array}{llll}-3.40936600 & 1.69939600 & -3.36378500\end{array}$ $\begin{array}{lll}-4.73922800 & 2.32432700 & -1.47341300\end{array}$ $\begin{array}{lll}-4.08359600 & 1.47958400 & 0.39132700\end{array}$ $\begin{array}{lll}-4.49009100 & 2.41197300 & -2.84659100\end{array}$ $\begin{array}{llll}-3.15945800 & 1.74424900 & -4.42042500\end{array}$ $\begin{array}{llll}-5.55386800 & 2.88289800 & -1.02248700\end{array}$ $\begin{array}{llll}-5.10600000 & 3.02401200 & -3.49630300\end{array}$ $\begin{array}{llll}-0.89185300 & -0.49161100 & -1.45089300\end{array}$ $\begin{array}{llll}-2.23339500 & -1.04932400 & 0.36547600\end{array}$ $\begin{array}{lll}-3.43760700 & -1.38752900 & 0.92875500\end{array}$ $\begin{array}{lll}-1.35164000 & -1.87169200 & 0.98716000\end{array}$ $\begin{array}{lll}-3.30183800 & -2.36614700 & 1.92388400\end{array}$ $-4.73271000-1.14084600 \quad 0.42883700$ $\begin{array}{llll}0.10955100 & -2.07852300 & 1.02054600\end{array}$ $\begin{array}{lll}-2.02534100 & -2.62110800 & 1.91895800\end{array}$ $\begin{array}{lll}-5.06547500 & -1.46227300 & -0.89031000\end{array}$ $\begin{array}{lll}-5.71924300 & -0.58940300 & 1.25114000\end{array}$ $\begin{array}{llll}0.56743600 & -1.22232600 & 1.52014000\end{array}$ $\begin{array}{llll}0.52314500 & -2.17196700 & 0.02118200\end{array}$ $\begin{array}{llll}0.21492700 & -3.38709100 & 1.83763000\end{array}$ 


\begin{tabular}{|c|c|c|c|}
\hline & -1.07887800 & -3.47567300 & 2.69749300 \\
\hline$F$ & -4.14835400 & -2.01087100 & -1.69551200 \\
\hline C & -6.33261600 & -1.19728300 & -1.39562700 \\
\hline C & -6.99522600 & -0.33686000 & 0.76026300 \\
\hline$F$ & -5.43960600 & -0.26979100 & 2.51872200 \\
\hline $\mathrm{H}$ & 1.11963100 & -3.39749800 & 2.44552800 \\
\hline $\mathrm{H}$ & 0.26401000 & -4.23488200 & 1.15017400 \\
\hline $\mathrm{H}$ & -1.44723000 & -4.49549100 & 2.82385300 \\
\hline $\mathrm{H}$ & -0.93862000 & -3.04333300 & 3.69479800 \\
\hline $\mathrm{F}$ & -6.62781700 & -1.48656200 & -2.66815500 \\
\hline C & -7.29944700 & -0.63479200 & -0.56619400 \\
\hline $\mathrm{F}$ & -7.92823000 & 0.20525000 & 1.55325100 \\
\hline$F$ & -8.52075700 & -0.37816500 & -1.04289300 \\
\hline N & -2.62552200 & 0.92621500 & -2.60420500 \\
\hline $\mathrm{H}$ & -1.17599000 & -0.13424200 & -2.33153300 \\
\hline । & 1.66961900 & 0.48556300 & -0.99570900 \\
\hline C & 3.45156200 & 1.41825400 & -0.28832700 \\
\hline C & 0.43283900 & 1.53333600 & 0.29397300 \\
\hline $\mathrm{O}$ & 3.55309600 & -1.16503300 & -2.18859000 \\
\hline C & 3.88746200 & 1.12179600 & 1.01286800 \\
\hline C & 4.16007000 & 2.25589900 & -1.16292200 \\
\hline C & -0.80877100 & 1.34743500 & 0.57460600 \\
\hline$S$ & 3.95213300 & -2.29481100 & -1.27030300 \\
\hline C & 5.07163000 & 1.73365700 & 1.44245500 \\
\hline C & 3.15139500 & 0.18412800 & 1.93405000 \\
\hline C & 5.33898000 & 2.83447200 & -0.67638200 \\
\hline C & 3.72465300 & 2.52508100 & -2.58131300 \\
\hline C & -1.75643300 & 1.99904600 & 1.47537800 \\
\hline $\mathrm{O}$ & 2.92758100 & -2.55186000 & -0.20961800 \\
\hline 0 & 4.39082200 & -3.50857500 & -2.00284100 \\
\hline C & 5.39622000 & -1.67051400 & -0.38716900 \\
\hline C & 5.80720500 & 2.58868000 & 0.61809400 \\
\hline $\mathrm{H}$ & 5.43221100 & 1.51543800 & 2.44400400 \\
\hline $\mathrm{H}$ & 2.17566600 & 0.59790900 & 2.21310300 \\
\hline $\mathrm{H}$ & 2.99048900 & -0.78597800 & 1.45240900 \\
\hline $\mathrm{H}$ & 3.72824400 & 0.02222900 & 2.84794900 \\
\hline $\mathrm{H}$ & 5.90744800 & 3.48720600 & -1.33449600 \\
\hline $\mathrm{H}$ & 3.72065700 & 1.60246400 & -3.17240000 \\
\hline $\mathrm{H}$ & 2.71494100 & 2.94777200 & -2.62240600 \\
\hline $\mathrm{H}$ & 4.40658600 & 3.23107000 & -3.06193600 \\
\hline C & -2.12598500 & 3.33643800 & 1.24357400 \\
\hline C & -2.34081400 & 1.31442400 & 2.55421400 \\
\hline C & 6.26572200 & -0.78103200 & -1.01731400 \\
\hline C & 5.66168100 & -2.11220600 & 0.91034500 \\
\hline C & 7.10775000 & 3.18652500 & 1.08999600 \\
\hline C & -3.06016000 & 3.96707800 & 2.06499200 \\
\hline $\mathrm{H}$ & -1.67497400 & 3.86542400 & 0.41062500 \\
\hline C & -3.27785900 & 1.94558000 & 3.37291800 \\
\hline $\mathrm{H}$ & -2.05150700 & 0.29071100 & 2.76453000 \\
\hline C & 7.40078600 & -0.33122500 & -0.34220100 \\
\hline $\mathrm{H}$ & 6.04393600 & -0.43498000 & -2.02039700 \\
\hline C & 6.79758400 & -1.65334000 & 1.57632000 \\
\hline $\mathrm{H}$ & 4.97593900 & -2.80106500 & 1.39163000 \\
\hline $\mathrm{H}$ & 7.94971400 & 2.53748800 & 0.81987100 \\
\hline $\mathrm{H}$ & 7.28801100 & 4.16450100 & 0.63279300 \\
\hline $\mathrm{H}$ & 7.12251700 & 3.30789400 & 2.17744600 \\
\hline C & -3.64677000 & 3.27161800 & 3.12705300 \\
\hline $\mathrm{H}$ & -3.33481400 & 5.00013100 & 1.87200100 \\
\hline $\mathrm{H}$ & -3.71980700 & 1.40135700 & 4.20178800 \\
\hline C & 7.68428500 & -0.75523900 & 0.96283600 \\
\hline $\mathrm{H}$ & 8.07127800 & 0.36764300 & -0.83542300 \\
\hline H & 6.99955000 & -1.99639600 & 2.58845800 \\
\hline $\mathrm{H}$ & -4.37951600 & $3 . / 5989900$ & 3.76264400 \\
\hline
\end{tabular}

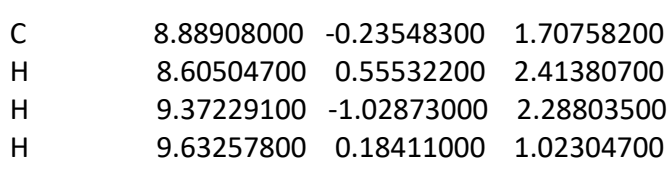

TS-Mes (toluene)

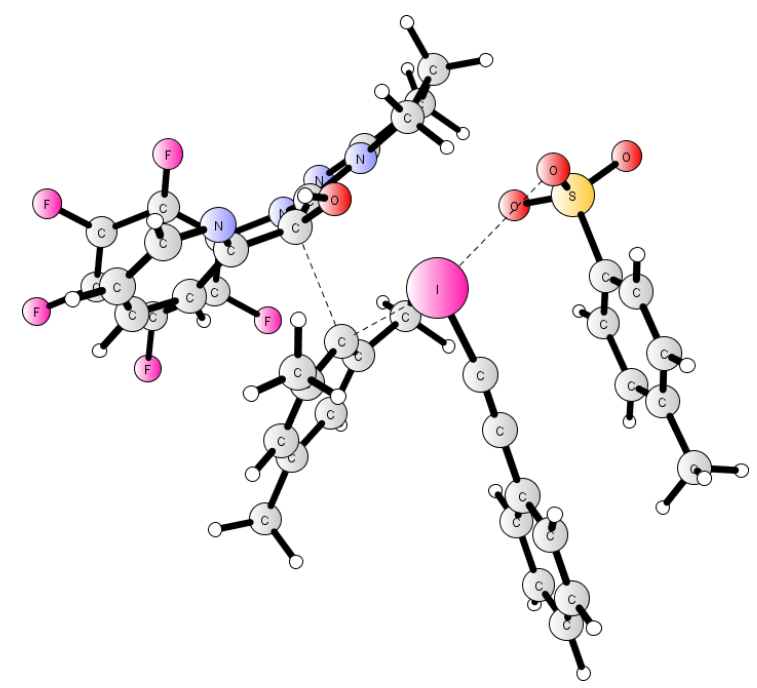

C $\quad-1.85405500 \quad 0.89554200 \quad 1.34075000$

C $\quad-2.82891000-0.00100100 \quad 1.98050300$

C $\quad-3.44372600-1.11694100 \quad 1.39254000$

C $\quad-3.82029700 \quad-0.46715300 \quad 4.02862800$

C $\quad-4.30859000-1.88671000 \quad 2.16481300$

H $\quad-3.20491600 \quad-1.40965900 \quad 0.38054200$

C $\quad-4.52154200-1.55410200 \quad 3.50452300$

H $\quad-3.91457800 \quad-0.19035700 \quad 5.07546600$

H $\quad-4.79037500 \quad-2.75708700 \quad 1.72948600$

$\mathrm{H} \quad-5.18637400 \quad-2.13456300 \quad 4.13460600$

$\begin{array}{lllll}0 & -1.08976600 & 1.59841100 & 2.25808300\end{array}$

C $\quad-1.98464300 \quad 1.60814600 \quad 0.12537500$

N $\quad-2.63512100 \quad 1.30554500 \quad-1.05574300$

N $\quad-1.32346400 \quad 2.76530900-0.16844200$

N $\quad-2.35938900 \quad 2.24583500 \quad-2.06229200$

C $\quad-3.73808800 \quad 0.45842400 \quad-1.26660900$

C $\quad-0.53826000 \quad 3.79564600 \quad 0.55219800$

C $\quad-1.56222200 \quad 3.09282000-1.47892800$

C $\quad-4.92258500 \quad 0.62454300 \quad-0.54270600$

C $\quad-3.69178500-0.54340200-2.24116800$

$\mathrm{H} \quad 0.47062100 \quad 3.43232400 \quad 0.73975400$

$\mathrm{H} \quad-1.03254100 \quad 4.04094100 \quad 1.49028600$

C $\quad-0.54440900 \quad 4.96469100 \quad-0.46423600$

C $\quad-0.84907900 \quad 4.34469800 \quad-1.85607700$

$\begin{array}{llll}F & -5.01340700 & 1.59858100 & 0.37196600\end{array}$

C $\quad-6.00545000-0.22653700 \quad-0.72747900$

C $\quad-4.77412100-1.39262800-2.44389000$

F $\quad-2.59944900-0.70622700-2.99087500$

$\mathrm{H} \quad 0.41690300 \quad 5.47875100 \quad-0.45826000$

H $\quad-1.32655700 \quad 5.68231000-0.19781500$

$\mathrm{H} \quad-1.44850200 \quad 4.98725100 \quad-2.50335900$

H $\quad 0.08402400 \quad 4.07654500 \quad-2.36025900$

F $\quad-7.11536400 \quad-0.08147900 \quad 0.00790500$

C $\quad-5.92918500-1.23851600-1.68002800$

F $\quad-4.70933600-2.36060400-3.36722200$

F $\quad-6.96343400 \quad-2.06642800-1.85978100$ 


\begin{tabular}{|c|c|c|c|}
\hline & -2.99597400 & 0.28225600 & 3.29248000 \\
\hline $\mathrm{H}$ & -1.52126000 & 1.40437600 & 3.12745500 \\
\hline & 1.40696300 & 0.55735300 & 1.74093100 \\
\hline C & -0.31934700 & -0.97389800 & 0.64065000 \\
\hline C & 2.70904700 & -0.79286900 & 1.09505900 \\
\hline O & 2.71876100 & 3.65102000 & 0.86130800 \\
\hline C & -0.56882100 & -2.07703100 & 1.45830400 \\
\hline C & -0.16695800 & -1.02359400 & -0.73995600 \\
\hline C & 3.36770000 & -1.72160000 & 0.66833100 \\
\hline$S$ & 2.98749600 & 3.41315000 & -0.59268800 \\
\hline C & -0.81067900 & -3.29126400 & 0.80014300 \\
\hline C & -0.52782800 & -2.04706800 & 2.96443000 \\
\hline C & -0.43643800 & -2.27077100 & -1.33706100 \\
\hline C & 0.32283000 & 0.10720700 & -1.60511700 \\
\hline C & 4.13800200 & -2.79848600 & 0.14430600 \\
\hline 0 & 1.77847600 & 2.90503600 & -1.31996800 \\
\hline 0 & 3.65026300 & 4.55627200 & -1.27784500 \\
\hline C & 4.16414900 & 2.04428600 & -0.64556700 \\
\hline C & -0.76625700 & -3.40599500 & -0.59428200 \\
\hline $\mathrm{H}$ & -1.03169200 & -4.16677600 & 1.40761100 \\
\hline $\mathrm{H}$ & 0.48269600 & -2.29612700 & 3.31154900 \\
\hline $\mathrm{H}$ & -0.78097000 & -1.07109900 & 3.37421900 \\
\hline $\mathrm{H}$ & -1.21568000 & -2.78523600 & 3.38551500 \\
\hline $\mathrm{H}$ & -0.36467900 & -2.33754600 & -2.42039100 \\
\hline $\mathrm{H}$ & 0.49964500 & 1.03166900 & -1.06118800 \\
\hline $\mathrm{H}$ & 1.28586500 & -0.16968700 & -2.04715700 \\
\hline $\mathrm{H}$ & -0.36611400 & 0.30780900 & -2.42934600 \\
\hline C & 3.94276300 & -3.21603900 & -1.18697100 \\
\hline C & 5.09559100 & -3.45322900 & 0.94176700 \\
\hline C & 5.05853700 & 1.84631700 & 0.40587000 \\
\hline C & 4.21120800 & 1.21663100 & -1.77047100 \\
\hline C & -1.00690200 & -4.73470000 & -1.26899800 \\
\hline C & 4.69353400 & -4.26888000 & -1.70505600 \\
\hline $\mathrm{H}$ & 3.20644200 & -2.70634900 & -1.79877300 \\
\hline C & 5.84386600 & -4.50371200 & 0.41313100 \\
\hline $\mathrm{H}$ & 5.24858100 & -3.12575600 & 1.96488300 \\
\hline C & 6.00239800 & 0.81955300 & 0.32675900 \\
\hline $\mathrm{H}$ & 5.00396300 & 2.48600300 & 1.28040400 \\
\hline C & 5.15802500 & 0.19653400 & -1.83855800 \\
\hline $\mathrm{H}$ & 3.50219300 & 1.37225700 & -2.57664500 \\
\hline $\mathrm{H}$ & -1.82119300 & -5.28733400 & -0.78833200 \\
\hline $\mathrm{H}$ & -1.26087900 & -4.60456800 & -2.32519400 \\
\hline $\mathrm{H}$ & -0.11166000 & -5.36734000 & -1.21975200 \\
\hline C & 5.64615000 & -4.91455400 & -0.90877500 \\
\hline $\mathrm{H}$ & 4.53885900 & -4.58418000 & -2.73266200 \\
\hline $\mathrm{H}$ & 6.58516700 & -4.99987100 & 1.03233400 \\
\hline C & 6.07459700 & -0.01424600 & -0.79634900 \\
\hline $\mathrm{H}$ & 6.69294800 & 0.66379300 & 1.15205700 \\
\hline $\mathrm{H}$ & 5.18778000 & -0.44978400 & -2.71253700 \\
\hline $\mathrm{H}$ & 6.23250700 & -5.73187800 & -1.31775000 \\
\hline C & 7.11511800 & -1.10078300 & -0.89973400 \\
\hline H & 7.92539200 & -0.80072500 & -1.57677300 \\
\hline 7 & 7.56264400 & -1.31966300 & 0.07387100 \\
\hline & 6.68737400 & -2.02765200 & -1.29313200 \\
\hline
\end{tabular}

$\lg \left(\mathrm{CHCl}_{3}\right)$

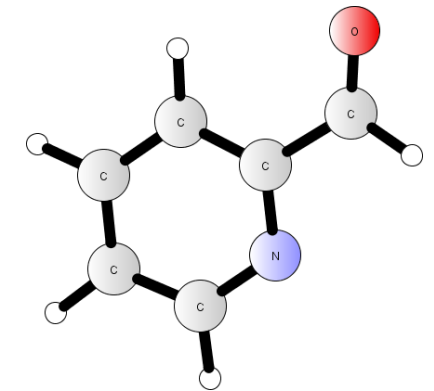

$\begin{array}{lrrr}\text { C } & -0.50237500 & -0.19491100 & -0.00020700 \\ \text { C } & -0.00972300 & 1.11509200 & -0.00007100 \\ \text { C } & 1.37153100 & 1.30104000 & 0.00024300 \\ \text { C } & 2.19781900 & 0.17590000 & 0.00040200 \\ \text { C } & 1.60970200 & -1.09443700 & 0.00023300 \\ \text { N } & 0.28656200 & -1.28618300 & -0.00005800 \\ \text { H } & 1.79552600 & 2.30043300 & 0.00036200 \\ H & -0.70175900 & 1.95040000 & -0.00021500 \\ H & 3.27871400 & 0.27261600 & 0.00065100 \\ \text { H } & 2.22841300 & -1.98832000 & 0.00035500 \\ \text { C } & -1.96135000 & -0.47697400 & -0.00057500 \\ \text { O } & -2.82829000 & 0.38347900 & -0.00011400 \\ H & -2.21412900 & -1.55393200 & 0.00001700\end{array}$

2a $\left(\mathrm{CHCl}_{3}\right)$

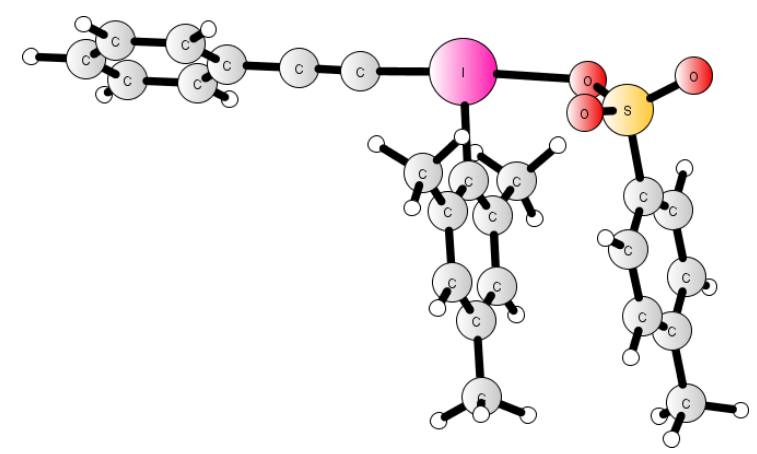

I $\quad 0.89376900-1.46952700 \quad-0.36932000$

$\begin{array}{lllll}\text { C } & & -0.06669500 & 0.40782400 & 0.01746200\end{array}$

C $\quad-0.67580600 \quad 1.05713700 \quad-1.06612800$

$\begin{array}{lllll}\text { C } & & -0.06240800 & 0.88604300 & 1.33405500\end{array}$

$\begin{array}{lllll}\text { C } & -1.31150800 & 2.27057800 & -0.77946800\end{array}$

$\begin{array}{llll}\text { C } & -0.71272200 & 2.11030300 & 1.54485800\end{array}$

$\begin{array}{llll}\text { C } & -1.33887500 & 2.81090000 & 0.51056400\end{array}$

$\begin{array}{llll}\mathrm{H} & -1.81159800 & 2.79274700 & -1.59035600\end{array}$

$\begin{array}{llll}\mathrm{H} & -0.74232700 & 2.50766000 & 2.55577700\end{array}$

$\begin{array}{lllll}\text { C } & 2.76023800 & -0.67066400 & -0.24717900\end{array}$

C $\quad 3.90082300 \quad-0.24615200-0.19234600$

$\begin{array}{lllll}\text { C } & 5.23054000 & 0.26804000 & -0.12677900\end{array}$

C $\quad 5.74173600 \quad 1.04839100 \quad-1.18327500$

$\begin{array}{llll}\text { C } & 6.04107100 & -0.00028600 & 0.99446300\end{array}$

C $\quad 7.03987700 \quad 1.55085800 \quad-1.11312200$

H $\quad \begin{array}{llll}\mathrm{C} & 5.11599500 & 1.25402600 & -2.04575100\end{array}$

$\begin{array}{llll}\text { C } & 7.33882400 & 0.50476000 & 1.05280000\end{array}$

$\begin{array}{llll}\text { H } & 5.64568300 & -0.60163800 & 1.80673100\end{array}$

$\begin{array}{lllll}\text { C } & 7.84041400 & 1.28048900 & 0.00204300\end{array}$

H $\quad 7.42790700 \quad 2.15292300 \quad-1.92921500$ 


$\begin{array}{lrrr}\text { H } & 7.95901500 & 0.29345900 & 1.91867400 \\ \text { H } & 8.85182800 & 1.67270500 & 0.05199700 \\ \text { O } & -1.40694600 & -2.26841900 & -0.68444900 \\ \text { S } & -2.47409400 & -2.24872800 & 0.41728800 \\ \text { O } & -3.41762100 & -3.37845000 & 0.24029200 \\ \text { O } & -1.85616700 & -2.12196300 & 1.76208400 \\ \text { C } & -3.39795800 & -0.73787100 & 0.12084500 \\ \text { C } & -3.63432200 & 0.14900200 & 1.16723500 \\ \text { C } & -3.90697200 & -0.48539700 & -1.15758200 \\ \text { C } & -4.38204600 & 1.30539900 & 0.92867600 \\ \text { H } & -3.22687100 & -0.05713100 & 2.15004100 \\ \text { C } & -4.64482100 & 0.67317600 & -1.38142200 \\ \text { H } & -3.72191700 & -1.18348200 & -1.96727100 \\ \text { C } & -4.89457400 & 1.58739300 & -0.34248200 \\ \text { H } & -4.55735800 & 2.00282000 & 1.74314200 \\ \text { H } & -5.03458700 & 0.87436400 & -2.37625500 \\ \text { C } & -5.68728800 & 2.84307000 & -0.60497700 \\ \text { H } & -6.69766700 & 2.60468400 & -0.95797400 \\ \text { H } & -5.78062500 & 3.45181200 & 0.29865400 \\ \text { H } & -5.21263200 & 3.45501300 & -1.38139200 \\ \text { C } & 0.56162000 & 0.15619600 & 2.49275500 \\ \text { H } & 0.11608900 & -0.83786800 & 2.60117100 \\ \text { H } & 1.64225100 & 0.03592800 & 2.35797200 \\ \text { H } & 0.39720400 & 0.71065600 & 3.41939400 \\ \text { C } & -0.69564100 & 0.50887300 & -2.46752200 \\ \text { H } & 0.31866200 & 0.39478900 & -2.86636900 \\ \text { H } & -1.17884700 & -0.47246100 & -2.49509600 \\ \text { H } & -1.24668500 & 1.18219600 & -3.12766100 \\ \text { C } & -2.03668200 & 4.11969700 & 0.77484900 \\ \text { H } & -2.97083000 & 4.18924200 & 0.20929800 \\ \text { H } & -2.26550900 & 4.24110300 & 1.83735500 \\ \text { H } & -1.40651800 & 4.96511200 & 0.47113300 \\ & & & \end{array}$

\section{$3 \mathrm{~g}\left(\mathrm{CHCl}_{3}\right)$}

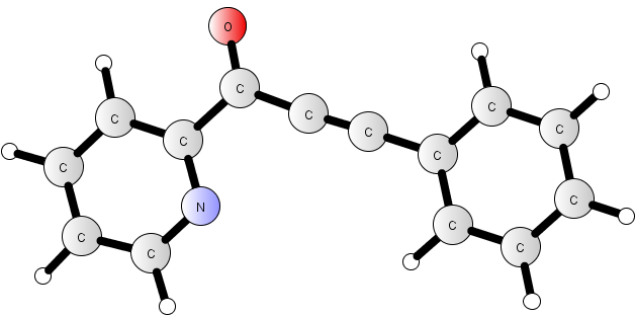

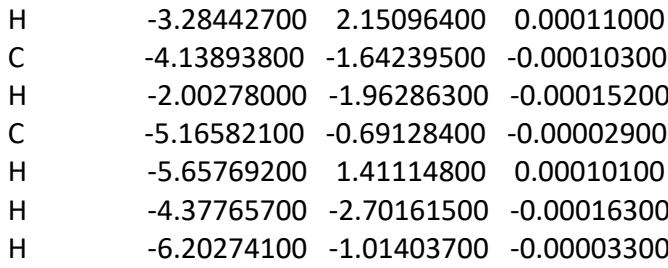

A $\left(\mathrm{CHCl}_{3}\right)$

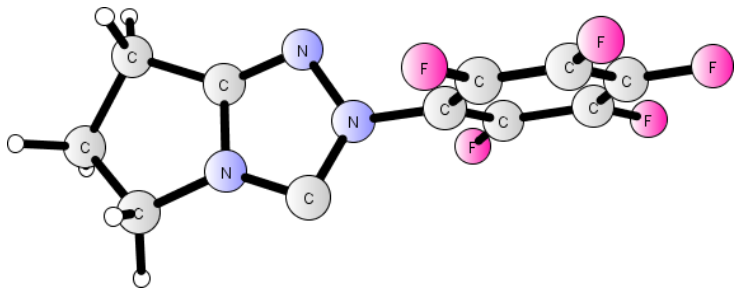

N $\quad-1.63223400 \quad 0.00075100 \quad 1.10430500$

N $\quad-0.93790800 \quad-0.05176900-0.12190700$

C $\quad-1.70584900-0.10954900-1.24413100$

N $\quad-2.93800300 \quad-0.08941800 \quad-0.67277100$

C $\quad-4.31811400-0.16123300-1.16765800$

H $\quad-4.54221500-1.19138200-1.46089600$

H $\quad-4.45040500 \quad 0.49289200 \quad-2.03014200$

C $\quad-5.12680000 \quad 0.28757700 \quad 0.07568400$

H $\quad-6.09788500 \quad-0.20791400 \quad 0.12654100$

$\begin{array}{llll}\mathrm{H} & -5.29609500 & 1.36722800 & 0.02670200\end{array}$

C $\quad-4.23342100-0.03748700 \quad 1.30935400$

H $\quad-4.34132600 \quad 0.68725400 \quad 2.11884800$

H $\quad-4.45109600-1.03220100 \quad 1.71530900$

C $\quad-2.86883000-0.02936900 \quad 0.70098100$

$0.47392300-0.02191600-0.08342600$

$0.48459500 \quad 2.34664600-0.09769000$

$\begin{array}{llll}1.16337700 & 1.19161200 & -0.06278800\end{array}$

$\begin{array}{llll}3.20187400 & 2.40310900 & 0.00853700\end{array}$

$\begin{array}{llll}2.55232500 & 1.22914900 & -0.00699400\end{array}$

$\begin{array}{llll}4.60852600 & 0.06538100 & 0.08379300\end{array}$

$\begin{array}{llll}3.27100400 & 0.03740900 & 0.03193500\end{array}$

$\begin{array}{llll}3.29957000 & -2.32895500 & 0.05991300\end{array}$

$2.60218400-1.18347700 \quad 0.01786000$

$0.58331000-2.38821700-0.04029300$

$1.21272700-1.20513400-0.03616500$

B $\left(\mathrm{CHCl}_{3}\right)$

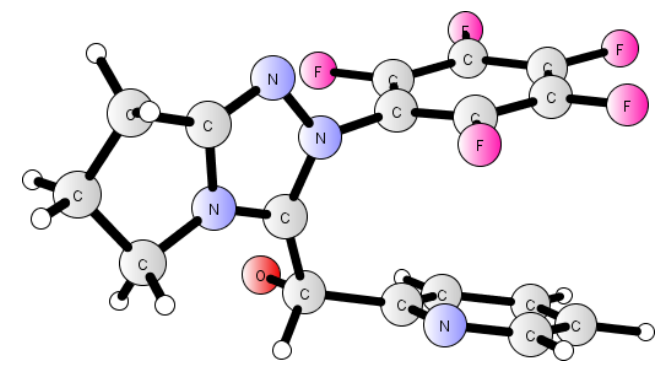

C $\quad-1.27575500 \quad 1.45021900 \quad 1.21807200$

$\mathrm{H} \quad-1.94210400 \quad 2.33511700 \quad 1.08005300$

C $\quad 0.11789500 \quad 1.93462600 \quad 0.78662900$

C $\quad 1.22725800 \quad 1.69059300 \quad 1.59788900$ 


$\begin{array}{llrr}\text { C } & 1.40582300 & 3.00464100 & -0.79156300 \\ \text { C } & 2.48015300 & 2.12355500 & 1.16399600 \\ \text { H } & 1.07654100 & 1.15908800 & 2.53084500 \\ \text { C } & 2.57590000 & 2.79198900 & -0.05903100 \\ \text { H } & 1.43959800 & 3.52445400 & -1.74652400 \\ \text { H } & 3.36699400 & 1.94039800 & 1.76451300 \\ \text { H } & 3.52980000 & 3.14293300 & -0.43961300 \\ \text { O } & -1.35992200 & 0.83748900 & 2.41158400 \\ \text { C } & -1.80786100 & 0.42240500 & 0.21028300 \\ \text { N } & -1.17348500 & -0.63528500 & -0.34645300 \\ \text { N } & -3.10092600 & 0.19195800 & -0.06086400 \\ \text { N } & -2.04974500 & -1.53951800 & -0.94968000 \\ \text { C } & 0.21628300 & -0.89316800 & -0.32964700 \\ \text { C } & -4.38725700 & 0.85113700 & 0.20466200 \\ \text { C } & -3.21573800 & -0.98914700 & -0.75185600 \\ \text { C } & 0.79512400 & -1.60714100 & 0.72093700 \\ \text { C } & 1.03273900 & -0.41116100 & -1.35461200 \\ \text { H } & -4.49244400 & 1.70719100 & -0.46668000 \\ \text { H } & -4.42702600 & 1.18884700 & 1.24041500 \\ \text { C } & -5.38483300 & -0.29367600 & -0.11199200 \\ \text { C } & -4.64585500 & -1.27109900 & -1.07474400 \\ \text { F } & 0.03307700 & -2.10994800 & 1.69432200 \\ \text { C } & 2.17201100 & -1.79207400 & 0.77354500 \\ \text { C } & 2.40990200 & -0.58547300 & -1.30641400 \\ \text { F } & 0.49198000 & 0.23846100 & -2.39029700 \\ \text { H } & -6.30748300 & 0.09192100 & -0.54775200 \\ \text { H } & -5.63400200 & -0.81788300 & 0.81431000 \\ \text { H } & -4.91273400 & -2.31654200 & -0.91075300 \\ \text { H } & -4.83834500 & -1.03119400 & -2.12654500 \\ \text { F } & 2.72935000 & -2.45946600 & 1.79356100 \\ \text { C } & 2.97669100 & -1.27278200 & -0.23664800 \\ \text { F } & 3.19281800 & -0.09715700 & -2.27853400 \\ \text { F } & 4.30274500 & -1.43627000 & -0.18061000 \\ \text { N } & 0.19786500 & 2.58777400 & -0.38414300\end{array}$

\section{$\mathrm{C}\left(\mathrm{CHCl}_{3}\right)$}

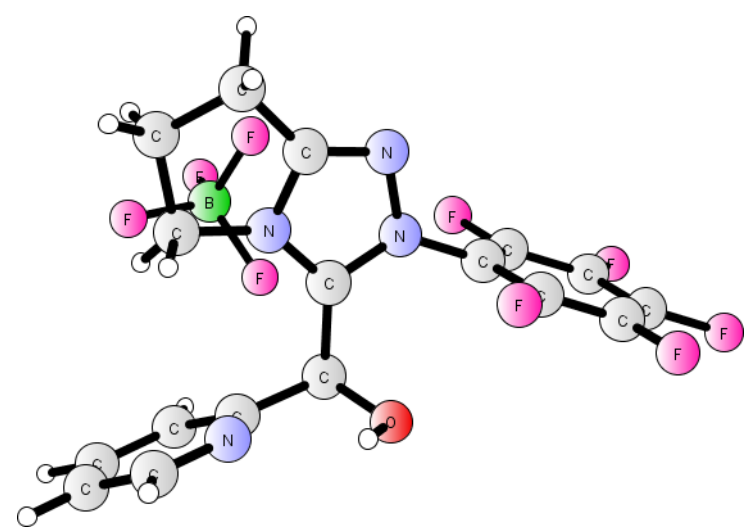

$\mathrm{H}$

$\mathrm{O}$

$\mathrm{C}$

$\mathrm{N}$

$\mathrm{N}$

C

C

$\mathrm{H}$

H

$\mathrm{F}$

$\mathrm{F}$

$\mathrm{H}$

B

$\mathrm{F}$

$\mathrm{F}$

$\mathrm{F}$ $\begin{array}{llll}5.30788100 & 3.43223000 & -1.45050500\end{array}$ $\begin{array}{lll}-0.44631200 & 2.21671400 & -0.74411200\end{array}$ $\begin{array}{lll}0.46150000 & 0.37978400 & 0.48021200\end{array}$ $\begin{array}{lll}-0.67138000 & -0.12722100 & 1.00570000\end{array}$ $\begin{array}{lll}1.42059900 & 0.02556400 & 1.33892600\end{array}$ $\begin{array}{lll}-0.44874100 & -0.79634600 & 2.19510500\end{array}$ $\begin{array}{lll}-1.98471900 & -0.03728900 & 0.47910500\end{array}$ $\begin{array}{lll}2.88597100 & 0.16806500 & 1.49328000\end{array}$ $\begin{array}{lll}0.84044400 & -0.68639600 & 2.36457000\end{array}$ $-2.47638900-1.02930800-0.37000200$ $\begin{array}{lll}-2.80808100 & 1.03313600 & 0.83027200\end{array}$ $\begin{array}{lll}3.09793800 & 1.19389900 & 1.80048800\end{array}$ $\begin{array}{llll}3.38049700 & -0.05625700 & 0.55145900\end{array}$ $\begin{array}{lll}3.18642200 & -0.87935200 & 2.59350100\end{array}$ $\begin{array}{lll}1.85584300 & -1.12184900 & 3.36271700\end{array}$ $-1.71064300-2.06986000-0.70020000$ $\begin{array}{lll}-1.7 .76908200 & -0.94380800 & -0.87825100\end{array}$ $\begin{array}{lll}-4.09900000 & 1.12597400 & 0.32765300\end{array}$ $\begin{array}{lll}-2.35374100 & 1.98292100 & 1.65412100\end{array}$ $\begin{array}{lll}3.98199100 & -0.53241900 & 3.25419000\end{array}$ $\begin{array}{llll}3.50609900 & -1.80838500 & 2.11930200\end{array}$ $\begin{array}{lll}1.71695500 & -2.16471700 & 3.65270900\end{array}$ $\begin{array}{lll}1.77840800 & -0.50127500 & 4.26228600\end{array}$ $-4.24039200-1.89482600-1.69396700$ $\begin{array}{lll}-4.57615100 & 0.13511000 & -0.52825900\end{array}$ $\begin{array}{lll}-4.88528600 & 2.15868100 & 0.65912100\end{array}$ $\begin{array}{lll}-5.81840200 & 0.22018000 & -1.01178800\end{array}$ $\begin{array}{lll}2.17013900 & 2.86758500 & -0.35348700\end{array}$ $\begin{array}{lll}-0.01341200 & 2.97390300 & -0.30663700\end{array}$ $\begin{array}{lll}2.05214500 & -2.60712100 & -0.85942400\end{array}$ $\begin{array}{llll}2.08400300 & -3.80869800 & -1.58479300\end{array}$ $3.36817100-2.11525500-0.68159100$ $\begin{array}{lll}1.45741600 & -2.81677000 & 0.40563400\end{array}$ $\begin{array}{lll}1.29495300 & -1.63783400 & -1.56818200\end{array}$
D $\left(\mathrm{CHCl}_{3}\right)$

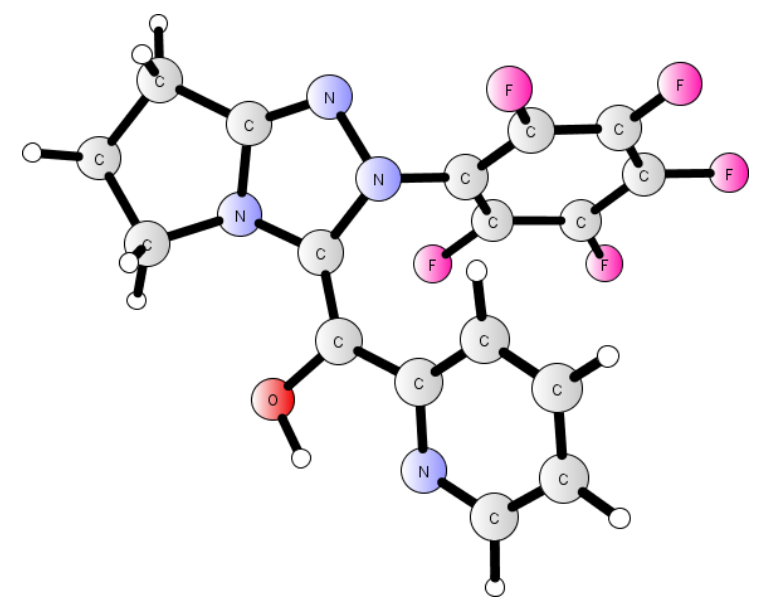

$\begin{array}{llll}\text { C } & -1.38829200 & 1.59658700 & 0.05152500\end{array}$

$\begin{array}{lllll}\text { C } & -0.16449400 & 2.26202400 & -0.34878000\end{array}$

C $\quad 0.76052100 \quad 1.77355700 \quad-1.29971700$

$\begin{array}{lllll}\text { C } & 1.08011800 & 4.20954100 & -0.09181000\end{array}$

C $\quad 1.88020000 \quad 2.53384500 \quad-1.60165500$

H $\quad 0.57246100 \quad 0.84658300 \quad-1.82445100$

$\begin{array}{lllll}\text { C } & 2.06631500 & 3.77485000 & -0.97432300\end{array}$

$\begin{array}{llll}\text { H } & 1.15671200 & 5.18172600 & 0.39016400\end{array}$ 


$\begin{array}{lrrr}\text { H } & 2.59577900 & 2.17401600 & -2.33548500 \\ \text { H } & 2.93203000 & 4.39384200 & -1.18360400 \\ \text { O } & -2.31356000 & 2.39158600 & 0.71605500 \\ \text { C } & -1.72533500 & 0.28115800 & -0.10465100 \\ \text { N } & -0.92659200 & -0.81987900 & -0.48100600 \\ \text { N } & -2.97252800 & -0.28817800 & 0.09127600 \\ \text { N } & -1.72876200 & -2.00301500 & -0.63367300 \\ \text { C } & 0.40017300 & -1.02126100 & -0.07215400 \\ \text { C } & -4.34392100 & 0.21319200 & 0.21718200 \\ \text { C } & -2.91429200 & -1.60253700 & -0.29823000 \\ \text { C } & 0.87284500 & -0.68050600 & 1.20206400 \\ \text { C } & 1.32084300 & -1.57852100 & -0.96890800 \\ \text { H } & -4.62808900 & 0.74660900 & -0.69787500 \\ \text { H } & -4.43342300 & 0.89208600 & 1.06368100 \\ \text { C } & -5.12719000 & -1.10906900 & 0.39903500 \\ \text { C } & -4.28798100 & -2.19679700 & -0.32754600 \\ \text { F } & 0.03553200 & -0.18893200 & 2.12849300 \\ \text { C } & 2.21009100 & -0.84086200 & 1.54795100 \\ \text { C } & 2.65244300 & -1.77245300 & -0.62491100 \\ \text { F } & 0.92497200 & -1.90132600 & -2.21057100 \\ \text { H } & -6.14187000 & -1.03522400 & 0.00377400 \\ \text { H } & -5.19117700 & -1.34635400 & 1.46497600 \\ \text { H } & -4.33460400 & -3.17541300 & 0.15471700 \\ \text { H } & -4.60138000 & -2.31972100 & -1.37042600 \\ \text { F } & 2.63585100 & -0.49590600 & 2.77393000 \\ \text { C } & 3.10279500 & -1.39440600 & 0.63631300 \\ \text { F } & 3.51238300 & -2.29729600 & -1.51301100 \\ \text { F } & 4.38936700 & -1.56653100 & 0.97171000 \\ \text { N } & -0.00416700 & 3.48632500 & 0.21677100 \\ \text { H } & -1.84559300 & 3.24225700 & 0.84925700 \\ & & & \end{array}$

\section{$\mathbf{E}\left(\mathrm{CHCl}_{3}\right)$}

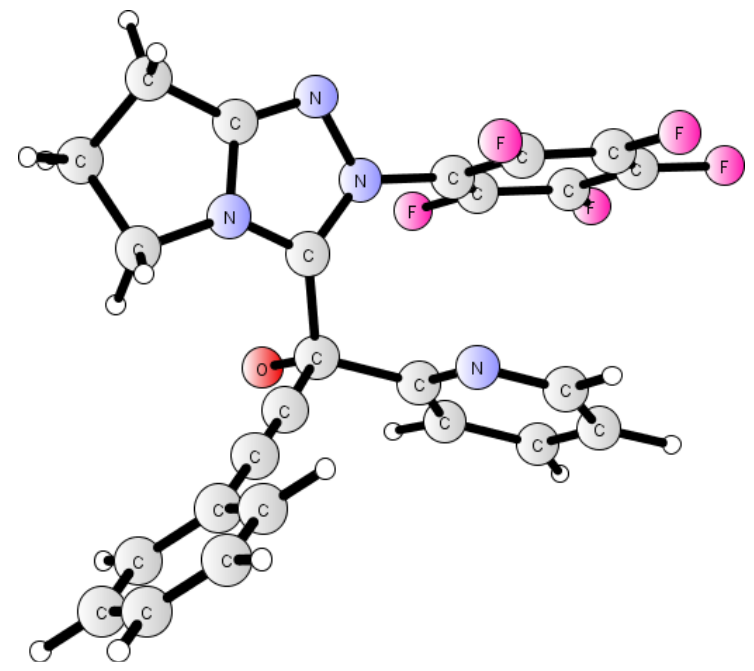

$\mathrm{N}$

$\begin{array}{rrr}-0.30222100 & 1.20535600 & -0.30374400 \\ 0.91543800 & 1.58328800 & 0.15276400 \\ -1.06017400 & 2.29995500 & -0.12709200 \\ 0.93452900 & 2.90732300 & 0.60376800 \\ 2.09934700 & 0.82143400 & 0.29631500 \\ -2.44362700 & 2.70961300 & -0.41853500 \\ -0.29380200 & 3.30009000 & 0.41173700 \\ 2.94245200 & 0.57396600 & -0.78602700 \\ 2.45119000 & 0.32933900 & 1.55437900 \\ -3.10639500 & 2.26871000 & 0.32909100 \\ -2.72615500 & 2.35791100 & -1.40992600 \\ -2.33446200 & 4.25167600 & -0.30407900 \\ -1.10188000 & 4.54004700 & 0.60336100 \\ 2.64493400 & 1.05274800 & -1.99674700 \\ 4.09761700 & -0.18414200 & -0.62385000 \\ 3.61136100 & -0.41229800 & 1.73007600 \\ 1.64910200 & 0.54705300 & 2.60220300 \\ -3.25070000 & 4.68582100 & 0.09847000 \\ -2.16013800 & 4.67435600 & -1.29710700 \\ -0.55663500 & 5.44075000 & 0.31628500 \\ -1.38447800 & 4.63340300 & 1.65806900 \\ 4.88937000 & -0.44217300 & -1.67379900 \\ 4.43164300 & -0.67245100 & 0.63528400 \\ 3.93005700 & -0.90233900 & 2.93683200 \\ 5.53723300 & -1.40819300 & 0.79281100 \\ 0.37394400 & -1.66785600 & 0.26285400 \\ -2.08939800 & -0.43384400 & -0.64429500 \\ -3.20712600 & -0.77021400 & -0.30620500 \\ -4.52485700 & -1.14755500 & 0.09914700 \\ -5.61708000 & -0.97558200 & -0.77518000 \\ -4.75078800 & -1.69147400 & 1.37976300 \\ -6.90224200 & -1.33943900 & -0.37385700 \\ -5.44493500 & -0.56098200 & -1.76350500 \\ -6.03954300 & -2.05112500 & 1.77305300 \\ -3.91046300 & -1.82862300 & 2.05306600 \\ -7.11853500 & -1.87691300 & 0.89960100 \\ -7.73590000 & -1.20476400 & -1.05701700 \\ -6.20151100 & -2.47042900 & 2.76189400 \\ -8.12066900 & -2.15988100 & 1.20833400 \\ & & \end{array}$

Mes-I $\left(\mathrm{CHCl}_{3}\right)$

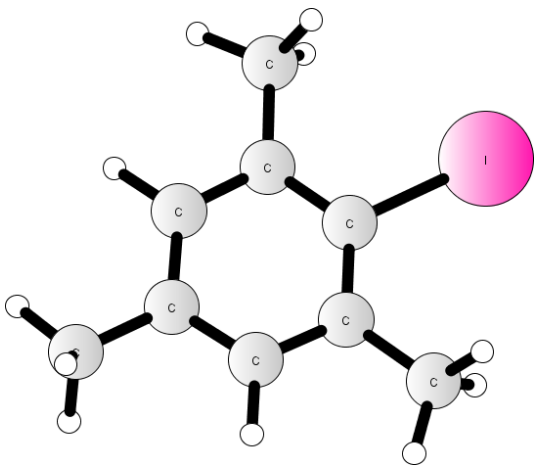

C

$\begin{array}{lll}-2.24720700 & -1.19705200 & -0.00594300\end{array}$ $-0.84620500-1.23101500-0.00240100$ $\begin{array}{llll}-0.16535700 & 0.00145400 & -0.00000600\end{array}$ $\begin{array}{llll}-0.84234000 & 1.23314800 & -0.00231800\end{array}$ $\begin{array}{llll}-2.24601600 & 1.20190400 & -0.00578900\end{array}$ $\begin{array}{llll}-2.96547300 & 0.00418800 & -0.00614400\end{array}$ $\begin{array}{lll}-2.78690300 & -2.14132200 & -0.00944400\end{array}$ 


$\begin{array}{llll}\text { H } & -2.78336500 & 2.14709200 & -0.00915300 \\ \mathrm{C} & -0.13255900 & 2.56208500 & -0.00308200 \\ \mathrm{H} & 0.51000600 & 2.67220300 & 0.87776900 \\ \mathrm{H} & 0.51157900 & 2.67058800 & -0.88300100 \\ \mathrm{H} & -0.85536900 & 3.38223300 & -0.00445700 \\ \mathrm{C} & -0.13722200 & -2.56040100 & -0.00295800 \\ \mathrm{H} & 0.50695000 & -2.66936100 & -0.88276700 \\ \mathrm{H} & 0.50512700 & -2.67077500 & 0.87799300 \\ \mathrm{H} & -0.86066200 & -3.38000000 & -0.00433700 \\ \mathrm{C} & -4.47414800 & -0.00153000 & 0.01021200 \\ \mathrm{H} & -4.85524700 & -0.32091600 & 0.98831600 \\ \mathrm{H} & -4.87820800 & 0.99402500 & -0.19555300 \\ \mathrm{H} & -4.87767600 & -0.69485600 & -0.73603900 \\ \mathrm{I} & 1.96609300 & -0.00123800 & 0.00172200\end{array}$

\section{NHC-1 $\left(\mathrm{CHCl}_{3}\right)$}

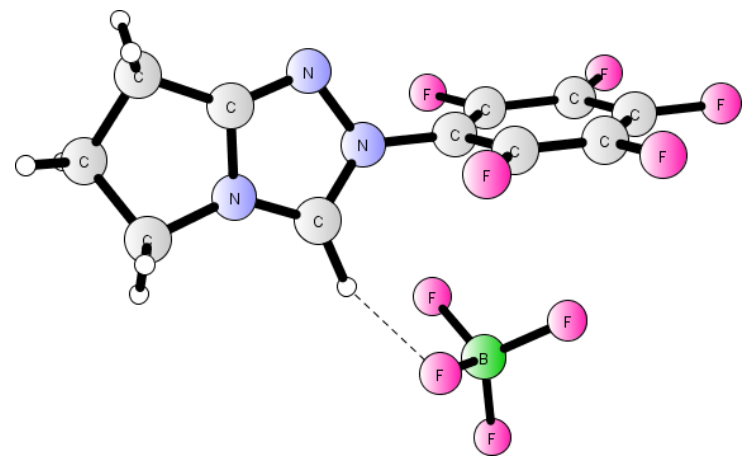

TMEDA $\left(\mathrm{CHCl}_{3}\right)$

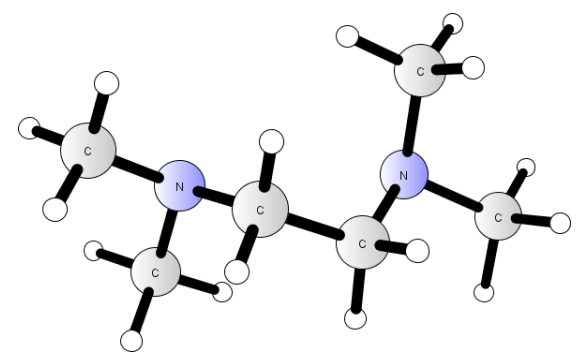

$\begin{array}{llll}\mathrm{N} & 2.03097700 & -1.68839500 & -0.26176700\end{array}$

N $\quad \begin{array}{llll}\text { N } & 1.17838400 & -0.65435200 & 0.08515300\end{array}$

$\begin{array}{lllll}\text { C } & 1.84283900 & 0.46294200 & 0.40735300\end{array}$

H $\quad 1.37997000 \quad 1.39933800 \quad 0.69983800$

$\begin{array}{lllll}\mathrm{N} & 3.13013800 & 0.15644200 & 0.27272700\end{array}$

$\begin{array}{llll}\text { C } & 4.44516000 & 0.80097300 & 0.45784600\end{array}$

H $\quad 4.65296200 \quad 0.85455600 \quad 1.52927000$

$\begin{array}{llll}\mathrm{H} & 4.43497000 & 1.80403800 & 0.03244100\end{array}$

$\begin{array}{lllll}\text { C } & 5.37197000 & -0.18974000 & -0.29122100\end{array}$

$\mathrm{H} \quad 6.35313700-0.24481900 \quad 0.18138000$

$\begin{array}{lllll}\mathrm{H} & 5.50369400 & 0.14947600 & -1.32182000\end{array}$

C $\quad 4.64317600-1.56660100-0.28869600$

$\mathrm{H} \quad 4.81326400-2.14289100 \quad-1.19959800$

H $\quad 4.93785700 \quad-2.18475200 \quad 0.56665000$

C $\quad 3.21755800 \quad-1.15514200 \quad-0.13505100$

C $\quad-0.22764400 \quad-0.83385900 \quad 0.04757800$

F $\quad-0.20399600 \quad-0.73587100 \quad-2.31383300$

C $\quad-0.89290000-0.87522200-1.17787500$

F $\quad-2.90826000-1.08986800-2.40043400$

C $\quad-2.26884800-1.05459800 \quad-1.22520900$

F $\quad-4.30926800-1.36238000-0.08101800$

C $\quad-2.98564000-1.19277300 \quad-0.03885700$

$\begin{array}{lllll}\text { F } & -3.03011800 & -1.28935000 & 2.32478500\end{array}$

C $\quad-2.33283300 \quad-1.15303300 \quad 1.19006700$

F $\quad-0.32605500 \quad-0.95037200 \quad 2.41010200$

$\begin{array}{llll}\text { C } & -0.95512200 & -0.97904700 & 1.22794300\end{array}$

B $\quad-0.95698700 \quad 2.71407800 \quad-0.04865000$

F $\quad-0.29406600 \quad 2.11344200 \quad-1.14700700$

F $\quad \begin{array}{llll}-2.14436600 & 2.01502800 & 0.22940900\end{array}$

F $\quad-1.22727500 \quad 4.06100200 \quad-0.32754400$

F $\quad \begin{array}{llll}-0.09145100 & 2.62896800 & 1.08765400\end{array}$
TMEDAH $^{+} \mathrm{BF}_{4}^{-}\left(\mathrm{CHCl}_{3}\right)$

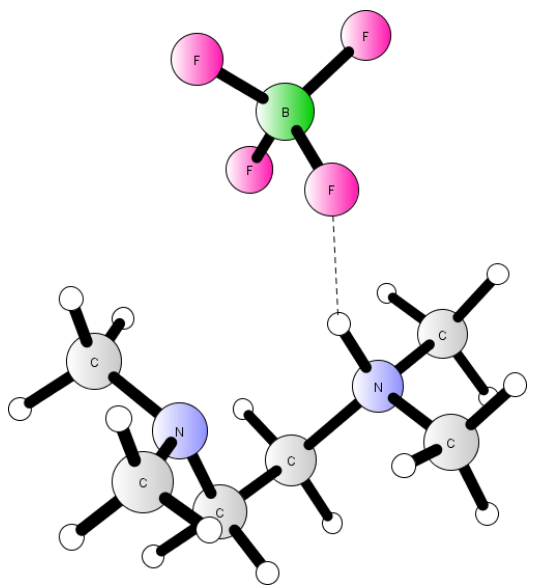

C

$\begin{array}{rrr}-0.69763600 & 0.31429800 & 0.91350100 \\ -0.61583800 & 1.40134100 & 1.01897900 \\ -1.20729500 & -0.04973000 & 1.82994400 \\ 0.69767800 & -0.31437600 & 0.91344000 \\ 1.20738000 & 0.04957000 & 1.82989200 \\ 0.61588200 & -1.40142800 & 1.01882500 \\ 1.50539100 & -0.04721800 & -0.27561500 \\ -1.50540400 & 0.04724300 & -0.27553900 \\ -1.71289400 & -1.37770200 & -0.50320200 \\ -2.21002400 & -1.87716000 & 0.35276300 \\ -2.34268900 & -1.51614900 & -1.38747500 \\ -0.75965500 & -1.87753100 & -0.68989500 \\ -2.77940600 & 0.75087900 & -0.18962100 \\ -3.35184900 & 0.59774600 & -1.11018400 \\ -3.40117800 & 0.40864100 & 0.66204100 \\ -2.60461800 & 1.82532500 & -0.07020400 \\ 1.71287300 & 1.37774600 & -0.50316500 \\ 2.21003600 & 1.87713100 & 0.35282500 \\ 2.34263800 & 1.51626600 & -1.38744800 \\ 0.75962900 & 1.87759200 & -0.68978200 \\ 2.77939600 & -0.75086400 & -0.18981600 \\ 3.35179300 & -0.59765700 & -1.11039500 \\ 3.40120900 & -0.40869800 & 0.66184300 \\ 2.60461000 & -1.82531900 & -0.07047900\end{array}$




$\begin{array}{lrrr}\text { H } & 0.97068000 & 0.75419300 & -1.85978500 \\ \text { N } & 0.60984500 & 1.51882100 & 0.04745900 \\ \text { N } & 1.85852800 & -1.08220300 & 0.11100200 \\ \text { C } & 1.13757500 & -1.93341700 & -0.83574600 \\ \text { H } & 1.82188600 & -2.43159700 & -1.54806400 \\ \text { H } & 0.58892700 & -2.70206400 & -0.28536500 \\ \text { H } & 0.40574100 & -1.35493600 & -1.40194500 \\ \text { C } & 2.77336100 & -1.87541900 & 0.92703500 \\ \text { H } & 2.21009200 & -2.65011100 & 1.45539500 \\ \text { H } & 3.55933000 & -2.37062300 & 0.32619200 \\ \text { H } & 3.26075200 & -1.23877900 & 1.67221800 \\ \text { C } & 1.27506500 & 2.01036200 & 1.29101700 \\ \text { H } & 1.95041700 & 2.82720000 & 1.03101700 \\ \text { H } & 0.50110400 & 2.36310800 & 1.97305200 \\ \text { H } & 1.81883900 & 1.18940900 & 1.75365500 \\ \text { C } & -0.35447600 & 2.53274200 & -0.47772600 \\ \text { H } & -1.10925600 & 2.72142200 & 0.28527000 \\ \text { H } & 0.19340800 & 3.44872800 & -0.70488100 \\ \text { H } & -0.82823000 & 2.13431900 & -1.37281800 \\ \text { H } & 0.06383800 & 0.68253100 & 0.31878600 \\ \text { F } & -1.77352000 & -0.16041200 & -1.17017800 \\ \text { B } & -2.33555700 & -0.49243300 & 0.08715300 \\ \text { F } & -1.36162900 & -0.18203000 & 1.09290700 \\ \text { F } & -3.48520800 & 0.28177600 & 0.31322400 \\ \text { F } & -2.63401500 & -1.85941400 & 0.13927000\end{array}$

\section{TMEDAH $^{+} \mathrm{TsO}^{-}\left(\mathrm{CHCl}_{3}\right)$}

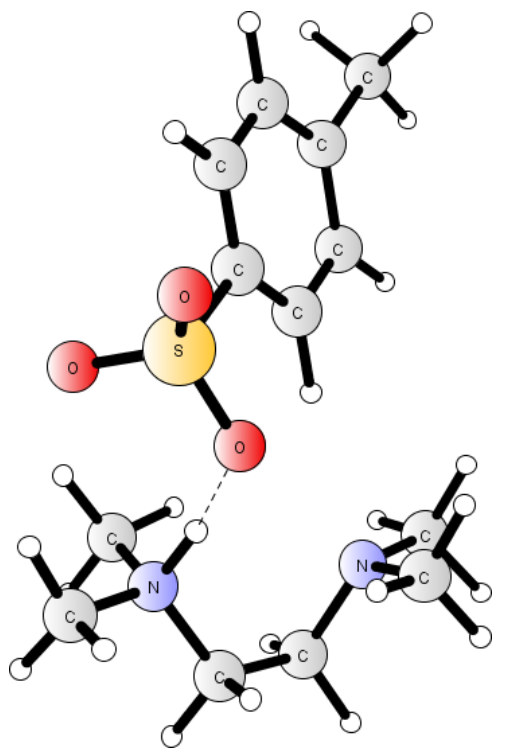

$\begin{array}{llll}\mathrm{C} & 3.04825900 & 1.87627400 & -0.20728400 \\ \mathrm{H} & 2.87488400 & 2.26614900 & -1.21457100 \\ \mathrm{H} & 3.86205000 & 2.48654800 & 0.23022700 \\ \mathrm{C} & 3.57366100 & 0.44756200 & -0.29552100 \\ \mathrm{H} & 4.41113500 & 0.41040900 & -0.99752600 \\ \mathrm{H} & 3.92569000 & 0.08581200 & 0.67229600 \\ \mathrm{~N} & 2.55071100 & -0.54633600 & -0.76328300 \\ \mathrm{~N} & 1.80377900 & 1.99642400 & 0.54401500 \\ \mathrm{C} & 1.97145300 & 1.71470200 & 1.96813500 \\ \mathrm{H} & 2.67253600 & 2.42030500 & 2.45251600 \\ \mathrm{H} & 1.00207600 & 1.79126700 & 2.46753200 \\ \mathrm{H} & 2.33334200 & 0.69652500 & 2.12248400 \\ \mathrm{C} & 1.19957200 & 3.31000500 & 0.34128900\end{array}$

$\begin{array}{rrr}0.24806800 & 3.36148000 & 0.87832100 \\ 1.84145300 & 4.13442900 & 0.70493100 \\ 1.00421900 & 3.47186100 & -0.72385200 \\ 1.86165900 & -0.14902900 & -2.02424100 \\ 2.60716800 & -0.00872100 & -2.80992100 \\ 1.16650800 & -0.94548800 & -2.28688800 \\ 1.30727200 & 0.77122100 & -1.85150900 \\ 3.16178200 & -1.90193900 & -0.89579400 \\ 2.36406900 & -2.61077000 & -1.11559000 \\ 3.90101200 & -1.88426400 & -1.69910300 \\ 3.63813400 & -2.16402500 & 0.04989600 \\ 1.80921900 & -0.64769300 & -0.01553500 \\ 0.72544500 & -1.19879200 & 1.11094200 \\ -0.43264100 & -1.96695600 & 0.51310800 \\ -0.06996300 & -2.52950600 & -0.82550600 \\ -1.01965700 & -2.95507500 & 1.45331300 \\ -1.69861000 & -0.72620100 & 0.20230200 \\ -3.02479600 & -1.13092900 & 0.02360700 \\ -1.34334400 & 0.61699200 & 0.08002100 \\ -3.99704000 & -0.17914700 & -0.27789800 \\ -3.29269700 & -2.17733300 & 0.12780900 \\ -2.33038700 & 1.55949600 & -0.22470000 \\ -0.31174400 & 0.92271000 & 0.22866500 \\ -3.66704300 & 1.18078100 & -0.40832200 \\ -5.02910100 & -0.49412200 & -0.41142200 \\ -2.05577100 & 2.60732100 & -0.31629600 \\ -4.73364600 & 2.19922500 & -0.72482100 \\ -4.30516700 & 3.19654700 & -0.85988900 \\ -5.27515100 & 1.93397900 & -1.64030900 \\ -5.47409000 & 2.25675600 & 0.08225900\end{array}$

TS1 $\left(\mathrm{CHCl}_{3}\right)$

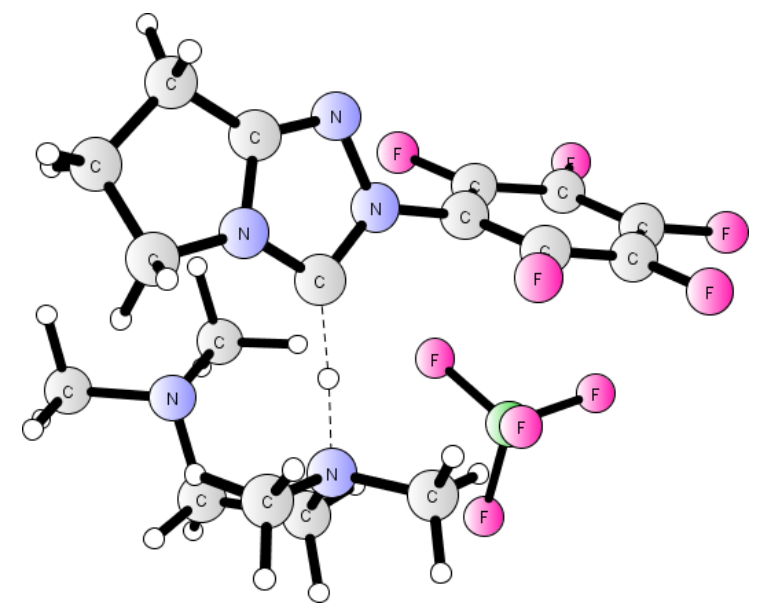

$\begin{array}{llll}\mathrm{H} & 1.47838600 & 0.48190100 & 1.15741100\end{array}$

$\begin{array}{llll}\mathrm{N} & 1.45752400 & 1.61875300 & 1.80785200\end{array}$

C $\quad \begin{array}{llll}1.19262300 & 2.75794500 & 0.88767400\end{array}$

$\begin{array}{llll}\text { C } & 2.76045800 & 1.70623700 & 2.49290900\end{array}$

$\begin{array}{lllll}\text { C } & 0.35814100 & 1.48735900 & 2.78785800\end{array}$

$\begin{array}{lllll}\text { C } & 2.30103900 & 3.01444000 & -0.12800400\end{array}$

H $\quad \begin{array}{llll}\mathrm{C} & 1.05144900 & 3.67032000 & 1.48260200\end{array}$

$\begin{array}{llll}\mathrm{H} & 0.24344900 & 2.54584900 & 0.39349500\end{array}$

$\begin{array}{llll}\mathrm{H} & 2.84298900 & 2.63971600 & 3.06255600\end{array}$

$\begin{array}{llll}\mathrm{H} & 2.85176500 & 0.86280700 & 3.18243000\end{array}$

$\begin{array}{llll}\mathrm{H} & 3.56817400 & 1.65184300 & 1.76244900\end{array}$

$\begin{array}{llll}\mathrm{H} & 0.50517200 & 0.57474000 & 3.37045100\end{array}$ 


\begin{tabular}{lrrr} 
H & 0.34136800 & 2.34802400 & 3.46705100 \\
$\mathrm{H}$ & -0.59176800 & 1.43284900 & 2.25540900 \\
$\mathrm{H}$ & 3.19970900 & 3.36992000 & 0.38558700 \\
$\mathrm{H}$ & 1.95787900 & 3.84574700 & -0.77229600 \\
$\mathrm{~N}$ & 2.67182300 & 1.83905600 & -0.91797900 \\
$\mathrm{C}$ & 1.60716200 & 1.43590200 & -1.83717600 \\
$\mathrm{C}$ & 3.90886900 & 2.08581500 & -1.65334200 \\
$\mathrm{H}$ & 1.37569900 & 2.22319700 & -2.57744000 \\
$\mathrm{H}$ & 1.91369900 & 0.53700900 & -2.38027300 \\
$\mathrm{H}$ & 0.68744900 & 1.21022800 & -1.29796500 \\
$\mathrm{H}$ & 4.19403100 & 1.18627300 & -2.20854800 \\
$\mathrm{H}$ & 3.81429200 & 2.91455500 & -2.38021300 \\
$\mathrm{H}$ & 4.71806100 & 2.33574200 & -0.95873600 \\
$\mathrm{C}$ & 1.60904100 & -0.75022700 & 0.55077300 \\
$\mathrm{~N}$ & 0.70818500 & -1.61964700 & 0.04351800 \\
$\mathrm{~N}$ & 2.77630600 & -1.32538800 & 0.21661200 \\
$\mathrm{~N}$ & 1.27724100 & -2.72238800 & -0.60076300 \\
$\mathrm{C}$ & -0.70061500 & -1.49965000 & 0.07525000 \\
$\mathrm{C}$ & 4.20012000 & -1.00954300 & 0.38294700 \\
$\mathrm{C}$ & 2.55394300 & -2.49636300 & -0.46728600 \\
$\mathrm{C}$ & -1.42218100 & -1.34787100 & -1.11011800 \\
$\mathrm{C}$ & -1.39883700 & -1.56201800 & 1.28120100 \\
$\mathrm{H}$ & 4.49696800 & -1.22464600 & 1.41314000 \\
$\mathrm{H}$ & 4.36609600 & 0.04364900 & 0.16193400 \\
$\mathrm{C}$ & 4.85347900 & -1.97361700 & -0.64060000 \\
$\mathrm{C}$ & 3.84520000 & -3.14464500 & -0.84399800 \\
$\mathrm{~F}$ & -0.77608100 & -1.27766300 & -2.27986700 \\
$\mathrm{C}$ & -2.80910300 & -1.26806000 & -1.09533800 \\
$\mathrm{C}$ & -2.78358700 & -1.46292700 & 1.30932400 \\
$\mathrm{~F}$ & -0.73292400 & -1.73138000 & 2.43569600 \\
$\mathrm{H}$ & 5.82703000 & -2.32484700 & -0.29564400 \\
$\mathrm{H}$ & 4.99538700 & -1.44984000 & -1.58978800 \\
$\mathrm{H}$ & 3.83828800 & -3.53145500 & -1.86450900 \\
$\mathrm{H}$ & 4.05111700 & -3.98021100 & -0.16550200 \\
$\mathrm{~F}$ & -3.48928300 & -1.12717000 & -2.23803400 \\
$\mathrm{C}$ & -3.48878600 & -1.32127100 & 0.11808100 \\
$\mathrm{~F}$ & -3.44126000 & -1.51422900 & 2.47736000 \\
$\mathrm{~F}$ & -4.82145600 & -1.23508800 & 0.14179900 \\
$\mathrm{~F}$ & -2.06401800 & 1.57882600 & 0.54332300 \\
$\mathrm{~F}$ & -2.54602500 & 2.15504000 & -0.66245400 \\
& -1.76782200 & 1.67556700 & -1.74038000 \\
& -3.89265200 & 1.78517400 & -0.84542000 \\
-2.43182900 & 3.55926200 & -0.58302300 \\
& & & \\
\hline
\end{tabular}

TS2 $\left(\mathrm{CHCl}_{3}\right)$

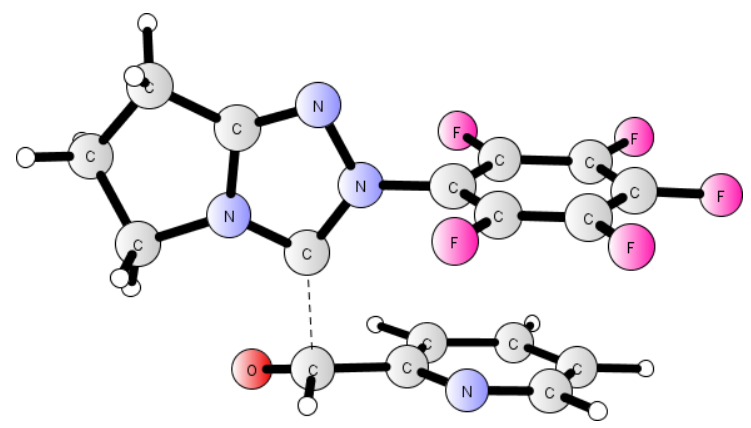

TS3 $\left(\mathrm{CHCl}_{3}\right)$

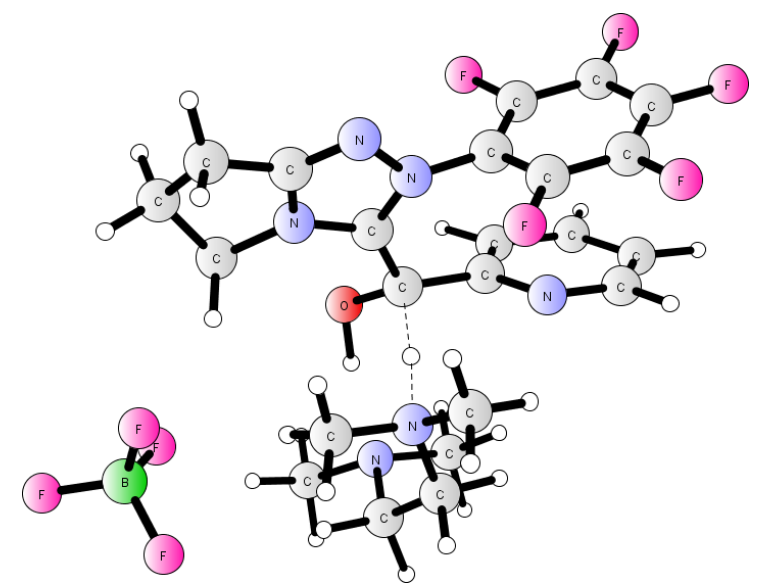

$\begin{array}{llll}2.14712000 & 1.90467100 & -1.20512300\end{array}$ $\begin{array}{lll}1.58497600 & 2.96757100 & 0.87032300\end{array}$ $\begin{array}{llll}-0.55980800 & 3.16019600 & 1.17040100\end{array}$ $\begin{array}{llll}2.56215800 & 2.50593400 & -0.01496100\end{array}$ $\begin{array}{llll}2.87863000 & 1.53637200 & -1.92111700\end{array}$ $\begin{array}{lll}1.86611600 & 3.43953900 & 1.80735500\end{array}$ $\begin{array}{lll}3.61984600 & 2.60658100 & 0.20707400\end{array}$ $\begin{array}{llll}-2.43184700 & 2.69338700 & -0.55785700\end{array}$ $\begin{array}{llll}-1.80250300 & 0.12274600 & -0.51274200\end{array}$ $\begin{array}{lll}-1.08802000 & -0.85257100 & 0.09543000\end{array}$ $\begin{array}{lll}-3.06520800 & -0.24462900 & -0.22970300\end{array}$ $\begin{array}{lll}-1.86576600 & -1.82120100 & 0.74974600\end{array}$ $\begin{array}{llll}0.31995300 & -0.96626000 & 0.13806300\end{array}$ $\begin{array}{lll}-4.41189000 & 0.27003400 & -0.52284500\end{array}$ $\begin{array}{lll}-3.07689600 & -1.39986000 & 0.51542400\end{array}$ $\begin{array}{lll}1.02945000 & -0.54767000 & 1.26375100\end{array}$ $1.02469400-1.50137400-0.93994500$ $\begin{array}{lll}-4.66157000 & 0.03057400 & -1.56045400\end{array}$ $\begin{array}{llll}-4.42560500 & 1.35054800 & -0.38698600\end{array}$ $\begin{array}{lll}-5.27146600 & -0.51939200 & 0.49546100\end{array}$ $\begin{array}{lll}-4.47693300 & -1.81983500 & 0.82140000\end{array}$ $\begin{array}{lll}0.37574600 & -0.03226400 & 2.31220900\end{array}$ $\begin{array}{lll}2.41518100 & -0.64016200 & 1.30796600\end{array}$ $2.41061200-1.60036700-0.90694000$ $\begin{array}{llll}0.36828100 & -1.91804800 & -2.02937700\end{array}$ $\begin{array}{lll}-6.26639900 & -0.73317300 & 0.10165600\end{array}$ $\begin{array}{lll}-5.38401800 & 0.07332100 & 1.40769900\end{array}$ $\begin{array}{lll}-4.60008500 & -2.15070100 & 1.85435200\end{array}$ $\begin{array}{lll}-4.76508900 & -2.64756900 & 0.16323900\end{array}$ $\begin{array}{lll}3.09176500 & -0.20716300 & 2.38141200\end{array}$ $\begin{array}{llll}3.10349100 & -1.16882100 & 0.22014500\end{array}$ $3.08267000-2.09710900-1.95587800$ $\begin{array}{llll}4.43982900 & -1.23893600 & 0.24895600\end{array}$ $\begin{array}{llll}0.85850800 & 1.73882000 & -1.53535000\end{array}$

$\begin{array}{llll}\text { C } & 0.10592800 & 0.40739600 & -0.63735100\end{array}$

$\begin{array}{llll}\mathrm{H} & 0.68293400 & 0.69225600 & 0.60907800\end{array}$

C $\quad-1.11345100 \quad 1.28663900 \quad-0.67832900$

C $\quad-1.52354000 \quad 1.89041600-1.87623900$

$\begin{array}{llll}\text { C } & -2.81987600 & 2.31311600 & 0.48810700\end{array}$

$\begin{array}{lllll}\text { C } & -2.63838200 & 2.72417200 & -1.86418500\end{array}$

H $\quad-0.97218800 \quad 1.69273900 \quad-2.78825800$

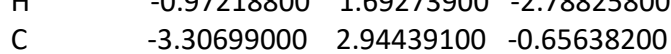

$\begin{array}{llll}\text { H } & -3.30692700 & 2.46155100 & 1.44975400\end{array}$ 


\begin{tabular}{|c|c|c|c|}
\hline $\mathrm{H}$ & -2.98563200 & 3.19048400 & -2.78162400 \\
\hline $\mathrm{H}$ & -4.17886700 & 3.58794900 & -0.60004900 \\
\hline 0 & 1.08432300 & 0.74972800 & -1.59808400 \\
\hline C & -0.07014000 & -1.01834500 & -0.59596100 \\
\hline $\mathrm{N}$ & -1.13694300 & -1.77241500 & -0.1783510 \\
\hline $\mathrm{N}$ & 0.88741200 & -1.94582100 & -0.8492100 \\
\hline $\mathrm{N}$ & -0.83806700 & -3.14281300 & -0.1268340 \\
\hline C & -2.46500900 & -1.35452000 & 0.04091300 \\
\hline C & 2.29524700 & -1.97498700 & -1.29606100 \\
\hline C & 0.39555400 & -3.19044000 & -0.53725100 \\
\hline C & -3.28902100 & -1.00453700 & -1.03054300 \\
\hline C & -2.97497800 & -1.26007900 & 1.33597500 \\
\hline $\mathrm{H}$ & 2.93974400 & -1.64216000 & -0.48241000 \\
\hline $\mathrm{H}$ & 2.43235600 & -1.31738100 & -2.15010900 \\
\hline C & 2.48007500 & -3.47750800 & -1.61545400 \\
\hline C & 1.43994500 & -4.23748300 & -0.74381900 \\
\hline$F$ & -2.83284000 & -1.10447100 & -2.28601900 \\
\hline C & -4.57662400 & -0.52767100 & -0.81587400 \\
\hline C & -4.26746300 & -0.80532000 & 1.56333900 \\
\hline$F$ & -2.20278700 & -1.57884900 & 2.38181200 \\
\hline $\mathrm{H}$ & 3.50211700 & -3.79847900 & -1.41055200 \\
\hline $\mathrm{H}$ & 2.26746900 & -3.65474200 & -2.67363500 \\
\hline $\mathrm{H}$ & 1.04432700 & -5.13537900 & -1.22191800 \\
\hline $\mathrm{H}$ & 1.86129600 & -4.52520000 & 0.22618800 \\
\hline$F$ & -5.35040700 & -0.16799900 & -1.84929000 \\
\hline C & -5.06454800 & -0.43248100 & 0.48441100 \\
\hline$F$ & -4.74016900 & -0.69523900 & 2.81354800 \\
\hline$F$ & -6.30179400 & 0.02822900 & 0.69871400 \\
\hline N & -1.74738900 & 1.50817400 & 0.48932500 \\
\hline $\mathrm{H}$ & 1.57427000 & 1.53885400 & -1.21005700 \\
\hline N & 2.22061400 & 2.97357200 & -0.55148600 \\
\hline C & 2.68534200 & 2.93851400 & 0.84557300 \\
\hline C & 1.18754800 & 3.99743200 & -0.75476500 \\
\hline C & 3.35900800 & 3.21263600 & -1.45213800 \\
\hline C & 1.67561600 & 2.40790200 & 1.85892800 \\
\hline $\mathrm{H}$ & 2.95887900 & 3.95551800 & 1.17524200 \\
\hline $\mathrm{H}$ & 3.60035000 & 2.34417900 & 0.88134500 \\
\hline $\mathrm{H}$ & 1.56659600 & 5.00571100 & -0.51825700 \\
\hline $\mathrm{H}$ & 0.86259100 & 3.98180200 & -1.79789800 \\
\hline $\mathrm{H}$ & 0.31585800 & 3.79478800 & -0.12947500 \\
\hline $\mathrm{H}$ & 3.00745800 & 3.21267900 & -2.48795100 \\
\hline $\mathrm{H}$ & 3.84580200 & 4.18047900 & -1.24806000 \\
\hline $\mathrm{H}$ & 4.09475900 & 2.41375900 & -1.33247600 \\
\hline $\mathrm{H}$ & 0.73500700 & 2.96138600 & 1.80924800 \\
\hline $\mathrm{H}$ & 2.10068000 & 2.57091000 & 2.85871900 \\
\hline $\mathrm{N}$ & 1.33389600 & 0.96537400 & 1.73841000 \\
\hline C & 2.52464800 & 0.09096900 & 1.72149200 \\
\hline C & 0.41958000 & 0.57422600 & 2.83068500 \\
\hline $\mathrm{H}$ & 3.15363800 & 0.27219800 & 2.59997200 \\
\hline $\mathrm{H}$ & 2.19420100 & -0.94871500 & 1.73151700 \\
\hline $\mathrm{H}$ & 3.10531900 & 0.26594800 & 0.81935000 \\
\hline $\mathrm{H}$ & 0.11484400 & -0.46366400 & 2.68684000 \\
\hline $\mathrm{H}$ & 0.92354400 & 0.66922700 & 3.80028700 \\
\hline $\mathrm{H}$ & -0.46705300 & 1.20717000 & 2.80195200 \\
\hline B & 5.74876300 & -0.63354700 & 0.31677500 \\
\hline$F$ & 4.99708400 & 0.01608900 & -0.69381800 \\
\hline$F$ & 6.98167300 & -1.06243900 & -0.21170100 \\
\hline$F$ & 5.01778800 & -1.75321200 & 0.78856900 \\
\hline $\mathrm{F}$ & 5.96709200 & 0.26532600 & 1.38492200 \\
\hline
\end{tabular}

TS4 $\left(\mathrm{CHCl}_{3}\right)$

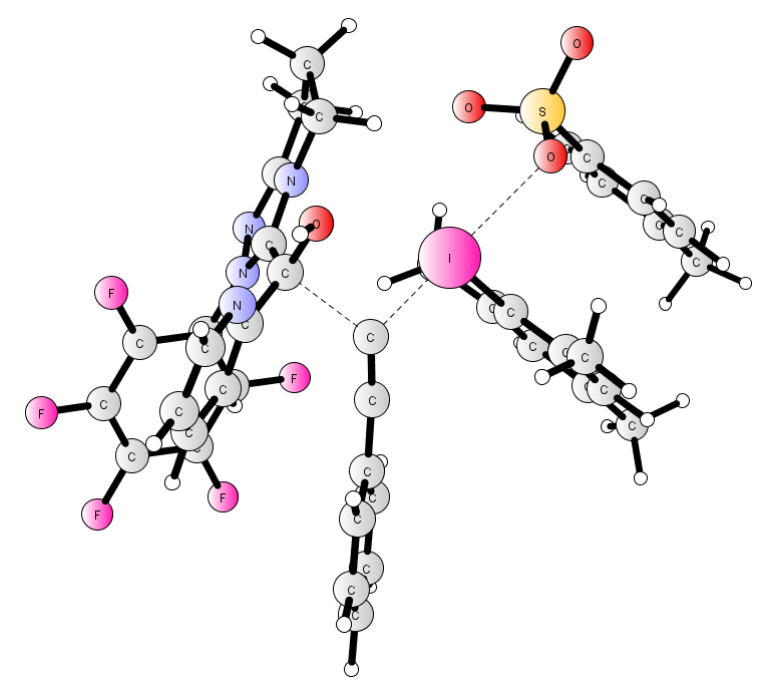

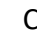

C

C

C

$\mathrm{H}$$$
\mathrm{H}
$$$$
\mathrm{H}
$$$$
\mathrm{H}
$$$$
\text { O }
$$$$
\text { C }
$$$$
\text { N }
$$$$
\text { N }
$$$$
\text { N }
$$$$
\text { C }
$$$$
\text { C }
$$$$
\text { C }
$$$$
\text { C }
$$$$
\text { C }
$$$$
\text { C }
$$$$
\mathrm{H}
$$$$
\text { C }
$$$$
\text { C }
$$$$
\mathrm{F}
$$$$
\text { C }
$$$$
\text { C }
$$$$
\text { F }
$$$$
\mathrm{H}
$$$$
\mathrm{H}
$$$$
\mathrm{H}
$$$$
\mathrm{H}
$$$$
\mathrm{F}
$$$$
\text { C }
$$$$
\mathrm{F}
$$$$
\mathrm{F}
$$$$
\text { N }
$$$$
\mathrm{H}
$$$$
\mathrm{H}
$$$$
\text { C }
$$$$
\text { C }
$$

\begin{abstract}
$\begin{array}{lll}1.79382000 & -1.83736200 & 1.00783000\end{array}$ $\begin{array}{llll}3.08837500 & -1.49325600 & 1.64209400\end{array}$ $\begin{array}{lll}3.91496000 & -0.41768700 & 1.28649800\end{array}$ $\begin{array}{llll}4.44343500 & -2.00553800 & 3.45467100\end{array}$ $\begin{array}{lll}5.06273900 & -0.18002700 & 2.03750200\end{array}$ $\begin{array}{llll}3.63949300 & 0.25390800 & 0.49043800\end{array}$ $\begin{array}{lll}5.35013400 & -0.99457200 & 3.13492200\end{array}$ $\begin{array}{llll}4.59715200 & -2.64262100 & 4.32182900\end{array}$ $\begin{array}{lll}5.71173500 & 0.65184500 & 1.78122700\end{array}$ $\begin{array}{lll}6.23390400 & -0.83647700 & 3.74350400\end{array}$ $\begin{array}{lll}1.02086300 & -2.67608900 & 1.79796200\end{array}$ $\begin{array}{llll}1.51553200 & -2.06918400 & -0.37401400\end{array}$ $1.93720400-1.43825900-1.52728900$ $\begin{array}{llll}0.49877000 & -2.87175200 & -0.81824400\end{array}$ $\begin{array}{lll}1.18933000 & -1.82623400 & -2.64956300\end{array}$ $3.04786600-0.60969000-1.76081900$ $\begin{array}{lll}-0.39658000 & -3.92642900 & -0.28368700\end{array}$ $\begin{array}{llll}0.33525100 & -2.67788600 & -2.16624300\end{array}$ $4.35285200-1.09711200-1.65493100$ $\begin{array}{llll}2.85890600 & 0.71671000 & -2.16256700\end{array}$ $\begin{array}{lll}-1.20694700 & -3.45891800 & 0.27519100\end{array}$ $\begin{array}{lll}0.16288100 & -4.60422700 & 0.35623500\end{array}$ $\begin{array}{lll}-0.91615400 & -4.58442600 & -1.58280400\end{array}$ $\begin{array}{lll}-0.78938000 & -3.50435100 & -2.68997500\end{array}$ $\begin{array}{llll}4.56247300 & -2.37421800 & -1.30948600\end{array}$ $\begin{array}{llll}5.44533000 & -0.26795500 & -1.87810200\end{array}$ $\begin{array}{llll}3.94411000 & 1.55041500 & -2.40533800\end{array}$ $\begin{array}{lll}1.62115300 & 1.19468400 & -2.32160900\end{array}$ $\begin{array}{llll}-1.94631900 & -4.91821400 & -1.45880300\end{array}$ $-0.29130800-5.44588900-1.83722100$ $\begin{array}{lll}-0.58825400 & -3.91115800 & -3.68227600\end{array}$ $\begin{array}{lll}-1.69298600 & -2.88703300 & -2.73681800\end{array}$ $6.69353400-0.73519400-1.73407800$ $\begin{array}{llll}5.23847200 & 1.05710800 & -2.25095200\end{array}$ $\begin{array}{llll}3.75493800 & 2.82000000 & -2.78631300\end{array}$ $\begin{array}{llll}6.28710700 & 1.85968100 & -2.46397500\end{array}$ $\begin{array}{lll}3.34292200 & -2.24566700 & 2.73315800\end{array}$ $\begin{array}{lll}1.59066100 & -2.87499400 & 2.57937900\end{array}$ $\begin{array}{lll}-1.18548800 & -0.76338000 & 1.64700800\end{array}$ $\begin{array}{lll}-2.06777400 & 1.01954100 & 0.91176000\end{array}$ $\begin{array}{lll}0.79141600 & 0.04155700 & 1.28872100\end{array}$ $\begin{array}{lll}-3.84476200 & -1.65456200 & 1.66118300\end{array}$ $\begin{array}{llll}-2.53005900 & 1.96647300 & 1.84022100\end{array}$
\end{abstract}




\begin{tabular}{|c|c|c|c|}
\hline & -2.11935600 & 1.20526700 & -0.47884000 \\
\hline & 1.26818800 & 1.18454400 & 1.28671300 \\
\hline & -4.37907600 & -2.11730000 & 0.32860500 \\
\hline & -3.06789200 & 3.14939300 & 1.32009000 \\
\hline & -2.47313300 & 1.76123100 & 3.33211700 \\
\hline & -2.66474400 & 2.41326000 & -0.93289400 \\
\hline & -1.61486000 & 0.19192300 & -1.47030500 \\
\hline & 1.91396900 & 2.44257400 & 1.25233000 \\
\hline 0 & -3.29627100 & -2.60433600 & -0.58028500 \\
\hline $\mathrm{O}$ & -5.51616800 & -3.06876800 & 0.47059000 \\
\hline & -5.03726000 & -0.63455100 & -0.45360200 \\
\hline & -3.14265800 & 3.39043000 & -0.05661100 \\
\hline H & -3.43693100 & 3.89965000 & 2.01488400 \\
\hline $\mathrm{H}$ & -3.04933700 & 0.88008600 & 3.63496700 \\
\hline$H$ & -1.44336700 & 1.61550400 & 3.67640400 \\
\hline 1 & -2.88415300 & 2.63117100 & 3.84997300 \\
\hline$H$ & -2.72174800 & 2.58289800 & -2.00437000 \\
\hline$H$ & -0.54006500 & 0.03416500 & -1.35006800 \\
\hline$H$ & -2.11634200 & -0.77081900 & -1.33768100 \\
\hline $\mathrm{H}$ & -1.79052300 & 0.53877400 & -2.49123400 \\
\hline & 1.76038700 & 3.30670200 & 0.14202600 \\
\hline & 2.73676300 & 2.86410500 & 2.32537500 \\
\hline & -5.54987400 & 0.39756400 & 0.33132200 \\
\hline & -5.06761200 & -0.54362400 & -1.84727300 \\
\hline & -3.75684300 & 4.66486100 & -0.57575900 \\
\hline & 2.41807400 & 4.53489300 & 0.10616900 \\
\hline & 1.11921500 & 3.00585500 & -0.67852200 \\
\hline & 3.38326800 & 4.09653400 & 2.27818200 \\
\hline & 2.86386000 & 2.20942600 & 3.18170600 \\
\hline & -6.09111300 & 1.52683500 & -0.28512000 \\
\hline & -5.50941200 & 0.32447200 & 1.41228700 \\
\hline & -5.60804400 & 0.59086300 & -2.45070700 \\
\hline & -4.65999200 & -1.34843200 & -2.44958700 \\
\hline & -4.84409500 & 4.65669500 & -0.43334000 \\
\hline & -3.36668100 & 5.53880200 & -0.04292300 \\
\hline & -3.55978900 & 4.79686100 & -1.64320500 \\
\hline & 3.23475400 & 4.93901900 & 1.16846900 \\
\hline & 2.29051000 & 5.18070300 & -0.75823800 \\
\hline & 4.01095700 & 4.40138500 & 3.11125200 \\
\hline & -6.12781200 & 1.64388000 & -1.68097400 \\
\hline & -6.48072100 & 2.33356800 & 0.32980600 \\
\hline & -5.62470100 & 0.66229300 & -3.53564700 \\
\hline & 3.74557100 & 5.89660700 & 1.13468100 \\
\hline & -6.68001900 & 2.87932400 & -2.34677400 \\
\hline & -5.87406300 & 3.48505200 & -2.77929700 \\
\hline & -7.36207900 & 2.61900500 & -3.16371300 \\
\hline & & & -1.6351070 \\
\hline
\end{tabular}

TS5 $\left(\mathrm{CHCl}_{3}\right)$

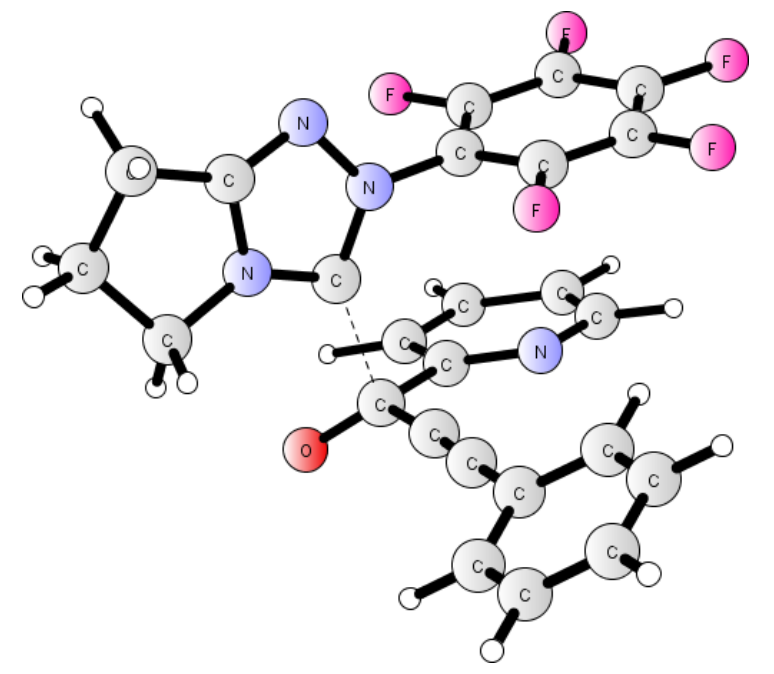

$\begin{array}{llll}\text { C } & 0.62729400 & 1.05579400 & 1.80205500\end{array}$

$\begin{array}{llll}\text { C } & -0.64817700 & 0.27423400 & 2.13015600\end{array}$

$\begin{array}{llll}\text { C } & -1.72054000 & 0.94852500 & 2.72306600\end{array}$

$\begin{array}{llll}\text { C } & -1.79387000 & -1.71850100 & 2.14530400\end{array}$

$\begin{array}{llll}\text { C } & -2.87914900 & 0.23316600 & 3.01573600\end{array}$

$\begin{array}{llll}\text { H } & -1.62749400 & 2.00620800 & 2.94165000\end{array}$

$\begin{array}{llll}\text { C } & -2.91966000 & -1.13336800 & 2.72492800\end{array}$

H $\quad-1.78253200 \quad-2.78019700 \quad 1.90894100$

$\begin{array}{llll}\mathrm{H} & -3.73462800 & 0.72881500 & 3.46521800\end{array}$

H $\quad-3.79927000 \quad-1.73180900 \quad 2.93953800$

$\begin{array}{lllll}0 & 0.89578400 & 2.08396000 & 2.49404400\end{array}$

$\begin{array}{llll}\text { C } & 0.11968200 & 1.69614600 & 0.00793200\end{array}$

$\begin{array}{llll}\mathrm{N} & -0.67562300 & 1.30462500 & -1.00976800\end{array}$

$\begin{array}{lllll}\mathrm{N} & 0.57318600 & 2.88474300 & -0.41848400\end{array}$

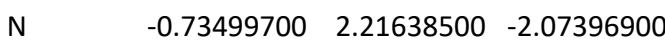

C $\quad \begin{array}{lllll}\text { C } & -1.42968900 & 0.11114200 & -1.06434000\end{array}$

$\begin{array}{lllll}\text { C } & & 1.50175000 & 3.91744200 & 0.07189700\end{array}$

C $\quad 0.05500200 \quad 3.16846900 \quad-1.66147900$

$\begin{array}{lllll}\text { C } & -2.78230400 & 0.11425100 & -0.72395100\end{array}$

C $\quad-0.82811700-1.09262100-1.43020100$

$\begin{array}{llll}\mathrm{H} & 2.52467100 & 3.55236600 & -0.05283400\end{array}$

$\begin{array}{llll}\mathrm{H} & 1.31961900 & 4.11095700 & 1.12687800\end{array}$

$\begin{array}{llll}\text { C } & 1.16601400 & 5.10072900 & -0.86896800\end{array}$

C $\quad 0.57439900 \quad 4.47383800 \quad-2.16700800$

F $\quad-3.37622400 \quad 1.25770100 \quad-0.35934700$

C $\quad-3.52197300-1.06171200-0.73536000$

C $\quad-1.55821000-2.27514800 \quad-1.44635100$

F $\quad 0.46707400 \quad-1.12113900-1.76173100$

H $\quad 2.04605300 \quad 5.71262100 \quad-1.07294500$

H $\quad 0.41019800 \quad 5.73446400 \quad-0.39624400$

$\begin{array}{lllll}H & -0.20396700 & 5.08741900 & -2.62448300\end{array}$

H $\quad \begin{array}{llll}1.34991600 & 4.29249700 & -2.91984800\end{array}$

F $\quad-4.81526300-1.05654500-0.38190900$

C $\quad-2.90534000-2.25629300-1.09755100$

F $\quad-0.97148700 \quad-3.43184600 \quad-1.78624100$

F $\quad-3.60829000 \quad-3.39499100 \quad-1.09176100$

N $\quad \begin{array}{llll}0.68114600 & -1.03312700 & 1.84036200\end{array}$

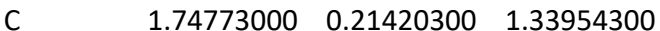

$\begin{array}{llll}\text { C } & 2.72701800 & -0.39828400 & 0.96245900\end{array}$

C $\quad 3.84404900 \quad-1.15549000 \quad 0.49623700$

C $\quad 5.16145500 \quad-0.70271900 \quad 0.71038100$

$\begin{array}{lllll}\text { C } & 3.63766400 & -2.37008100 & -0.18967800\end{array}$

$\begin{array}{lllll}\text { C } & 6.24422500 & -1.44967100 & 0.24726200\end{array}$ 


\begin{tabular}{|c|c|c|c|}
\hline $\mathrm{H}$ & 5.32248400 & 0.23015400 & 1.24153400 \\
\hline C & 4.72648900 & -3.10959200 & -0.64942100 \\
\hline $\mathrm{H}$ & 2.62333000 & -2.71979400 & -0.35250300 \\
\hline C & 6.03155100 & -2.65328600 & -0.43358300 \\
\hline $\mathrm{H}$ & 7.25561600 & -1.09261500 & 0.41882400 \\
\hline & 4.55641900 & -4.04414800 & -1.1762400 \\
\hline & 6.87731600 & -3.23265300 & -0.792312 \\
\hline
\end{tabular}

\section{$\mathrm{TS} \beta\left(\mathrm{CHCl}_{3}\right)$}

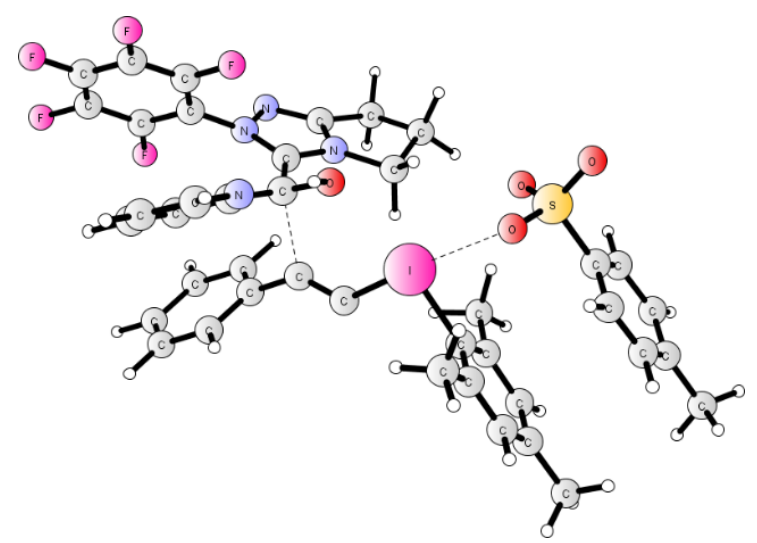

H

I

C

C

O

C

C

C

C

C

C

C

0

C

C

$\mathrm{H}$

$\mathrm{H}$

$\mathrm{H}$

$\mathrm{H}$

$\mathrm{H}$

H

$\mathrm{H}$

C

C

C

C

C

C

$\mathrm{H}$

C

$\mathrm{H}$

C

$\mathrm{H}$

C

$\mathrm{H}$

$\mathrm{H}$

$\mathrm{H}$ $\begin{array}{lll}-1.10270600 & -0.35191200 & -2.24820700\end{array}$

$\begin{array}{llll}1.67127100 & 0.37408200 & -0.95663100\end{array}$

$\begin{array}{llll}3.44035600 & 1.37212400 & -0.30663900\end{array}$

$\begin{array}{lll}0.44114400 & 1.50308200 & 0.26517400\end{array}$

$\begin{array}{llll}3.56760600 & -1.32941700 & -2.15885400\end{array}$

$\begin{array}{lll}3.91046000 & 1.10902300 & 0.98956400\end{array}$

$\begin{array}{llll}4.09161700 & 2.23938500 & -1.19861900\end{array}$

$\begin{array}{llll}-0.80043100 & 1.37541500 & 0.55495200\end{array}$

$4.05009500-2.40038200-1.21423300$

$\begin{array}{lll}5.07489200 & 1.77632900 & 1.39308200\end{array}$

$\begin{array}{lll}3.22786700 & 0.15760100 & 1.93782100\end{array}$

$\begin{array}{llll}5.25269500 & 2.87277700 & -0.73879100\end{array}$

$\begin{array}{llll}3.60609200 & 2.49469800 & -2.60335100\end{array}$

$\begin{array}{lll}-1.76901900 & 2.06368700 & 1.39667800\end{array}$

$\begin{array}{llll}3.06615100 & -2.69304600 & -0.12704900\end{array}$

$4.53550200-3.61413000-1.92989800$

$\begin{array}{llll}5.48212400 & -1.67947400 & -0.39145900\end{array}$

$\begin{array}{llll}5.75682200 & 2.65580300 & 0.54880400\end{array}$

$\begin{array}{lll}5.46132100 & 1.58502600 & 2.39043500\end{array}$

$\begin{array}{lll}2.24318900 & 0.53836000 & 2.23235000\end{array}$

$\begin{array}{lll}3.08771500 & -0.82457500 & 1.47569200\end{array}$

$\begin{array}{llll}3.82769400 & 0.03134200 & 2.84240100\end{array}$

$\begin{array}{llll}5.77680800 & 3.54825800 & -1.41072300\end{array}$

$\begin{array}{llll}3.60510300 & 1.57263300 & -3.19514500\end{array}$

$\begin{array}{llll}2.58419700 & 2.88935200 & -2.61037300\end{array}$

$\begin{array}{llll}4.25414700 & 3.21813100 & -3.10429500\end{array}$

$\begin{array}{lll}-2.21490700 & 3.35013400 & 1.04175500\end{array}$

$\begin{array}{lll}-2.29592400 & 1.45584300 & 2.54949000\end{array}$

$\begin{array}{llll}6.28032700 & -0.75720400 & -1.06816700\end{array}$

$\begin{array}{llll}5.81177800 & -2.07908900 & 0.90548400\end{array}$

$\begin{array}{llll}7.03345800 & 3.32313900 & 0.99271000\end{array}$

$\begin{array}{lll}-3.17051900 & 4.00633800 & 1.81825500\end{array}$

$\begin{array}{lll}-1.80927400 & 3.81970400 & 0.15166500\end{array}$

$\begin{array}{lll}-3.25435300 & 2.11235500 & 3.32124800\end{array}$

$\begin{array}{lll}-1.94030900 & 0.47582600 & 2.84919000\end{array}$

$\begin{array}{llll}7.40896600 & -0.23064700 & -0.43879600\end{array}$

$\begin{array}{llll}6.00998900 & -0.44273600 & -2.06986200\end{array}$

$\begin{array}{llll}6.94065000 & -1.54340100 & 1.52465400\end{array}$

$\begin{array}{llll}5.18207200 & -2.79275300 & 1.42587200\end{array}$

$\begin{array}{llll}7.90416100 & 2.82428200 & 0.54992500\end{array}$

$\begin{array}{llll}7.06499600 & 4.37168000 & 0.67827000\end{array}$

$\begin{array}{llll}7.14648400 & 3.28636900 & 2.08000300\end{array}$

$\begin{array}{lll}-3.70063500 & 3.38654500 & 2.95441200\end{array}$

$\begin{array}{lll}-3.50666200 & 4.99868400 & 1.53150800\end{array}$

$\begin{array}{lll}-3.65320200 & 1.62911700 & 4.20805300\end{array}$

$\begin{array}{llll}7.75598700 & -0.61038000 & 0.86491100\end{array}$

$\begin{array}{llll}8.02219300 & 0.49536100 & -0.96582400\end{array}$

$\begin{array}{lll}7.19163100 & -1.85107100 & 2.53704900\end{array}$

$\begin{array}{llll}-4.45122700 & 3.89372200 & 3.55348700\end{array}$

$\begin{array}{lll}8.95043200 & -0.00745800 & 1.56099500\end{array}$

$\begin{array}{llll}8.63735600 & 0.75544200 & 2.28499100\end{array}$

$\begin{array}{llll}9.51392200 & -0.76654500 & 2.11422300\end{array}$

$\begin{array}{llll}9.62953400 & 0.47007700 & 0.84858000\end{array}$ 
TS-Mes $\left(\mathrm{CHCl}_{3}\right)$

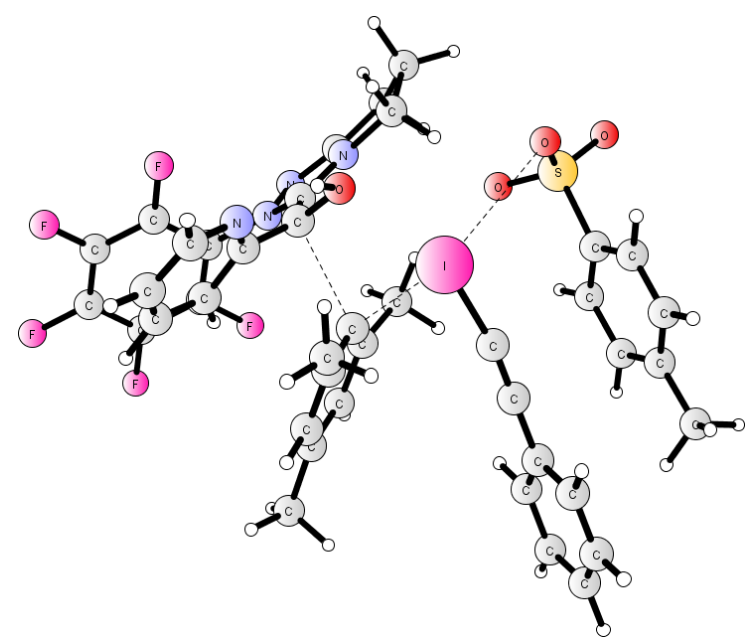

$\begin{array}{lll}-3.34127900 & 1.74925800 & 0.68437000\end{array}$ $\begin{array}{llll}-3.11170000 & -3.46243200 & -0.61606400\end{array}$ $\begin{array}{lll}0.76996900 & 3.29646000 & 0.64880600\end{array}$ $\begin{array}{lll}0.52014600 & 2.14483000 & 2.86571500\end{array}$ $\begin{array}{llll}0.37864900 & 2.18749600 & -1.44115900\end{array}$ $\begin{array}{lll}-0.33207000 & -0.21116600 & -1.61161900\end{array}$ $\begin{array}{lll}-4.08493800 & 2.83789100 & 0.14491200\end{array}$ $\begin{array}{lll}-1.90048600 & -3.02558000 & -1.37888400\end{array}$ $\begin{array}{llll}-3.85811600 & -4.56946200 & -1.28719100\end{array}$ $-4.22445400-2.04268100-0.63525200$ $\begin{array}{llll}0.70454200 & 3.35564000 & -0.74734100\end{array}$ $\begin{array}{llll}0.99029000 & 4.19678200 & 1.21882400\end{array}$ $\begin{array}{lll}-0.48871600 & 2.40658300 & 3.20859700\end{array}$ $\begin{array}{lll}0.77987700 & 1.18931600 & 3.31691800\end{array}$ $\begin{array}{lll}1.20842600 & 2.90487300 & 3.24485600\end{array}$ $\begin{array}{lll}0.29404000 & 2.20992000 & -2.52560800\end{array}$ $\begin{array}{lll}-0.54789000 & -1.09544800 & -1.01773300\end{array}$ $\begin{array}{llll}-1.26277500 & 0.05239300 & -2.12454600\end{array}$ $\begin{array}{lll}0.39773500 & -0.47271300 & -2.38259000\end{array}$ $\begin{array}{llll}-3.88589800 & 3.22362600 & -1.19578800\end{array}$ $\begin{array}{lll}-5.01727500 & 3.53570300 & 0.93617800\end{array}$ $\begin{array}{lll}-5.10793100 & -1.83027100 & 0.42340200\end{array}$ $-4.24847300-1.19954700-1.74948300$ $\begin{array}{llll}0.91636100 & 4.65786600 & -1.48069100\end{array}$ $\begin{array}{llll}-4.60995300 & 4.28746900 & -1.72983600\end{array}$ $\begin{array}{llll}-3.16828100 & 2.68178900 & -1.80244100\end{array}$ $\begin{array}{llll}-5.73885200 & 4.59697100 & 0.39132500\end{array}$ $\begin{array}{lll}-5.17238900 & 3.23403000 & 1.96703200\end{array}$ $\begin{array}{lll}-6.02021900 & -0.77449200 & 0.36031800\end{array}$ $\begin{array}{lll}-5.07345400 & -2.48074100 & 1.29100400\end{array}$ $-5.16529300-0.15074300-1.80160800$ $-3.54831800-1.36382300-2.56172200$ $\begin{array}{llll}1.57116200 & 5.33064100 & -0.91813900\end{array}$ $\begin{array}{lll}1.35975800 & 4.49223600 & -2.46773100\end{array}$ $\begin{array}{llll}-0.03705400 & 5.17969600 & -1.63335300\end{array}$ $\begin{array}{llll}-5.53859000 & 4.97557800 & -0.94017700\end{array}$ $\begin{array}{llll}-4.45286500 & 4.57836400 & -2.76432000\end{array}$ $\begin{array}{lll}-6.46079100 & 5.12691300 & 1.00553500\end{array}$ $\begin{array}{lll}-6.07258300 & 0.07355200 & -0.75414300\end{array}$ $\begin{array}{lll}-6.70153400 & -0.60702900 & 1.19083700\end{array}$ $\begin{array}{lll}-5.17677000 & 0.50750000 & -2.66674400\end{array}$ $\begin{array}{llll}-6.10396100 & 5.80145700 & -1.36159300\end{array}$ $\begin{array}{llll}-7.08461800 & 1.18770600 & -0.84075900\end{array}$ $\begin{array}{llll}-7.92915000 & 0.89512900 & -1.47819400\end{array}$ $\begin{array}{lll}-7.48617800 & 1.43935300 & 0.14478100\end{array}$ $\begin{array}{llll}-6.64641800 & 2.09165800 & -1.27324700\end{array}$ 
